\author{
UNIVERSIDADE DE SÃO PAULO \\ FACULDADE DE ECONOMIA, ADMINISTRAÇÃO E CONTABILIDADE \\ DEPARTAMENTO DE ECONOMIA \\ PROGRAMA DE PÓS-GRADUAÇÃO EM ECONOMIA
}

TRÊS ENSAIOS SOBRE COMPETITIVIDADE EXTERNA E DESEMPENHO ECONÔMICO NA DÉCADA DE 2000

Veridiana Ramos da Silva Carvalho

Orientador: Prof. Dr. Gilberto Tadeu Lima

SÃO PAULO 
Prof. Dr. João Grandino Rodas

Reitor da Universidade de São Paulo

Prof. Dr. Carlos Roberto Azzoni

Diretor da Faculdade de Economia, Administração e Contabilidade

Prof. Dr. Denisard Cnéio de Oliveira Alves

Chefe do Departamento de Economia

Prof. Dr. Dante Mendes Aldrighi

Coordenador do Programa de Pós-graduação em Economia 


\title{
TRÊS ENSAIOS SOBRE COMPETITIVIDADE EXTERNA E DESEMPENHO ECONÔMICO NA DÉCADA DE 2000
}

\author{
Tese apresentada ao Departamento de Econo- \\ mia da Faculdade de Economia, Administração \\ e Contabilidade da Universidade de São Paulo \\ como requisito para a obtenção do título de \\ Doutor em Economia.
}

Orientador: Prof. Dr. Gilberto Tadeu Lima 


\section{FICHA CATALOGRÁFICA}

Elaborada pela Seção de Processamento Técnico do SBD/FEA/USP

Carvalho, Veridiana Ramos da Silva

Três ensaios sobre competitividade externa e desempenho econômico na década de 2000 / Veridiana Ramos da Silva Carvalho. -- São Paulo, 2010.

$146 \mathrm{p}$.

Tese (Doutorado) - Universidade de São Paulo, 2010.

Orientador: Gilberto Tadeu de Lima.

1. Desenvolvimento econômico 2. Economia internacional 3. Macroeconomia I. Universidade de São Paulo. Faculdade de Economia, Administração e Contabilidade II. Título.

CDD - 338.9 
Esta tese é para a pessoa que eu mais amo neste mundo, e para a única pessoa que poderia me amar a ponto de superar todas as dificuldades que o desenvolvimento deste projeto exigiu: para meu adorado marido, Irineu Aversani Júnior. 


\section{Agradecimentos}

Meu agradecimento inicial e mais importante é para meu amado marido, Irineu Aversani Júnior, que esteve ao meu lado em todos os momentos difíceis, fazendo com que eu possa afirmar com toda a certeza, que se não fosse por ele, esta tese não existiria.

Também gostaria muito de agradecer ao meu orientador, Prof. Dr. Gilberto Tadeu Lima, pelo excelente trabalho de orientação e por ter dado todo o suporte quando foi necessário. Reitero minha admiração profissional e pessoal à pessoa mais importante da minha formação acadêmica.

Cabem agradecimentos especiais à instituição FEA-USP e a todo suporte de profissionais da Universidade de São Paulo que foram fundamentais ao colaborarem na minha reabilitação. Em especial, devo agradecer ao Prof. Dr. Guilhoto, Prof. Dr. Dante, Márcia Bento, Valéria Lourenção, Prof. Marcos Rojo, Prof. Kazue, Doutora Marina Miranda, Doutor Fábio Beites, entre outros.

Agradeço com muito zelo ao meu co-orientador na University of Cambridge (UK), Prof. John McCombie pela constante presença e por ter oferecido essa grande oportunidade de enriquecimento intelectual. Durante essa estadia em Cambridge gostaria de agradecer ao meu College, Homerton College, e ao Prof. Phillip Arestis com quem tive oportunidade de discutir meu projeto em diversas ocasiões.

Agradeço também ao Prof. David Kupfer que permitiu que eu passasse um semestre na UFRJ e tivesse aula com o excelente Prof. Dr. Mario Possas, que contribuiu enormemente para este trabalho, ainda que indiretamente. Agradeço também aos professores Pedro Cavalcanti, Samuel Pessoa e aos professores Ilan Goldfajn e Afonso Bevilaqua pela oportunidade de fazer parte do meu curso na EPGE e na PUC-Rio. Constatando que esse "sanduíche" nacional diversificado foi bastante importante para minha formação acadêmica, que culminou nesta tese. Agradeço em especial a Cristina Reis e Fernanda Cardoso que me apoiaram muito nessa fase.

Agradeço a todos os Professores do Mestrado e Doutorado da FEA-USP e das demais instituições que contribuíram para minha formação acadêmica, aos coordenadores da pósgraduação, às secretárias e aos funcionários da FEA e das demais instituições que estive envolvida.

Agradeço aos membros de minha banca de qualificação, Professores Raúl Cristóvão dos Santos e Mauro Rodrigues, que colaboraram significativamente e diretamente na elaboração deste trabalho.

Agradeço aos diversos amigos e colegas da FEA, Ana Carolina, Danilo Freitas, Raphael Gouvêa, entre muitos outros que conheci ao longo desses oito anos de Pós-Graduação na FEA, e que sempre contribuíram solidariamente com este trabalho e com a minha formação em geral, de forma que citá-los particularmente seria completamente inviável. Finalmente agradeço todos os meus amigos que me deram muita força nesta jornada, a começar novamente pelo meu marido Júnior, minha cachorrinha Morena e todos meus queridíssimos amigos-irmãos: Babi, Liliam Sampaio, Rui Santos, Vanuzia Rodrigues, Paula, Andreiona, Janaína, Luciana Machado, Marcelo Carvalho, Tatiana Pinheiro, Leandro da 
Silva, Irineu Aversani, Marlene e Rose Aversani, Joaquim da Silva, minha mãe Malú, e muitos outros grandes amigos que sempre me deram o suporte emocional que foi fundamental neste período.

Por fim, não poderia deixar de mencionar que, se por um lado a defesa desta tese é uma enorme alegria, ela é, por outro lado, uma enorme tristeza, fruto do encerramento de todo um ciclo educacional na Universidade de São Paulo que se iniciou no pré-primário e se encerrou com este doutorado. Gostaria de ressaltar que, quaisquer que forem meus caminhos profissionais a partir daqui, meu alicerce educacional sempre terá sido fruto desta Universidade. 
"WHY HAVE SOME countries grown rich while others remain poor? It is hard to think of a more fundamental question for economists to answer." Temple (1999) 


\section{Resumo}

O objetivo central desta tese é analisar o desempenho econômico de um conjunto amplo de países sob a ótica da competitividade externa, que explicita a competitividade estrutural relativa das economias. Para isso esta tese conta com três ensaios. $\mathrm{O}$ primeiro ensaio constrói um índice de qualidade da pauta exportadora e qualidade da pauta importadora para 143 países e comprova a significância desses índices na determinação da renda per capita. Além disso, o ensaio utiliza os resultados para analisar os canais de transmissão entre setor externo e renda apontados por alguns modelos de crescimento. O segundo ensaio faz um teste do modelo de crescimento sob restrição externa para um conjunto de 137 países utilizando uma nova metodologia empírica que recupera a idéia de teste conjunto sem recair em vários problemas de endogeneidade, recorrendo a técnicas de painel. O terceiro ensaio elabora um modelo Kaldoriano de causação cumulativa e o aplica para a economia brasileira no período 2003-2008. O modelo revela que a economia brasileira passou por um ciclo virtuoso de crescimento que se originou no mercado externo e foi internalizado pela economia. Com os argumentos explorados nos três ensaios comprova-se o papel da competitividade externa no desempenho econômico das nações e debate-se alguns dos canais de transmissão entre setor externo e renda.

Palavras-Chave: Desempenho Econômico, Competitividade Externa, Canais de Transmissão entre Setor Externo e Renda. 


\section{Abstract}

The main aim of this thesis is to analyze the economic performance of nations in the 2000s on the perspective of external competitiveness. For that, this thesis has three essays. The first essay builds an index of quality of export basket and an index of quality of import basket for 143 countries and demonstrates the significance of these indexes in determining the per capita income. Moreover, the essay uses the results to discuss the transmission channels between the external sector and income indicated by some growth models. The second essay is a balance-ofpayment constrain growth test applied to a set of 137 countries, using a new empirical methodology that recovers the idea of a whole test for several countries, without falling into various problems of endogeneity, using panel techniques. The third essay elaborates a Kaldorian model of cumulative causation and applies to the Brazilian economy 2003-2008. The model reveals that the Brazilian economy went through a virtuous cycle of growth that originated in the external sector and was internalized by the economy. With the arguments explored in the three essays, it was possible to prove the role of external competitiveness in economic performance and to discuss some of the transmission channels between the external sector and income.

Key-Words: Economic Performance, External Competitiveness, Transmission Channels between External Sector and Income. 


\section{Sumário}

Resumo

Lista de Tabelas

Lista de Figuras

Lista de símbolos

1 Introdução: o estudo do crescimento econômico e a conjuntura dos anos 2000

2 Ensaio I: A importância da pauta do comércio externo no desempenho econômico das nações na década de 2000

2.1 Introdução . . . . . . . . . . . . . . . . . . . 25

2.2 Síntese dos modelos que estabelecem relações entre pauta de comércio externo e desempenho econômico . . . . . . . . . . . . . . . . . . . . 27

2.3 Metodologia empírica adotada e fonte de dados . . . . . . . . . . . . . . 42

2.4 Experimentos empíricos $\ldots \ldots \ldots \ldots \ldots$. . . . . . . . . . . . . 44

2.4.1 desagregação a 2 dígitos . . . . . . . . . . . . . . . . 44

2.4 .2 desagregação a 4 dígitos . . . . . . . . . . . . . . . . 46 
2.5 Teorias de crescimento em economias abertas e resultados empíricos deste ensaio — algumas considerações . . . . . . . . . . . . . . . . . 53

2.6 Considerações finais $\ldots \ldots \ldots \ldots$. . . . . . . . . . . . . . . 60

3 Ensaio II: A restrição externa e o desempenho das economias nos anos 2000 uma análise em painel de dados $\quad 62$

3.1 Introdução . . . . . . . . . . . . . . . . . . . . . . . 62

3.2 As origens dos modelos de restrição externa e o estruturalismo . . . . . . . . . 63

3.3 Modelos de crescimento sob restrição externa . . . . . . . . . . . . . . . 67

3.4 Metodologia empírica . . . . . . . . . . . . . . . . . . . . . . 69

3.5 Resultados empíricos . . . . . . . . . . . . . . . . . . 71

3.5.1 Estimação do modelo . . . . . . . . . . . . . . . . . . . 71

3.5.2 Estimação das elasticidades-renda das importações . . . . . . . . . . . 73

3.5.3 Elasticidade-renda e competitividade da pauta . . . . . . . . . . . . 77

3.6 Considerações finais $\ldots \ldots \ldots \ldots \ldots$

4 Ensaio III: Brasil 2003-2008 - uma análise da competitividade externa e do cres$\begin{array}{ll}\text { cimento com base em um modelo Kaldoriano } & 81\end{array}$

4.1 Introdução . . . . . . . . . . . . . . . . . . . . . . 81

4.2 Caracterização da economia brasileira na década de 2000 . . . . . . . . . . . . 83

4.3 Aspectos da competitividade externa . . . . . . . . . . . . . . 88

4.4 Modelos de crescimento com causação cumulativa $\ldots \ldots$. . . . . . . . . . . 94

4.4.1 Regime de produtividade . . . . . . . . . . . . . . 97

4.4.2 Regime de demanda . . . . . . . . . . . . . . . . . 98

4.4.3 Estabilidade do equilíbrio . . . . . . . . . . . . . . . 102

4.5 Evidências empíricas — Brasil anos 2000 . . . . . . . . . . . . . 103

4.6 Considerações finais . . . . . . . . . . . . . . . . . 111

5 Considerações finais: competitividade externa e desempenho econômico na década 
de 2000 - relações, canais de transmissão e contribuições à literatura

Referências Bibliográficas

Anexo A - PRODYX e PRODYM (2 Dígitos) para 1999

Anexo B - Lista de Produtos, PRODYX e PRODYM

Anexo C - Lista de países, EXPY e IMPY

Anexo D - Resultados do Teste de Hausman

Anexo E - Modelo teórico da Estimação por Efeito Fixo, Efeito Aleatório e Teste de Hausman

E.1 Efeito Fixo ou Mínimos Quadrados Ordinários (MQO) com variáveis dummy . 135

E.2 Efeito Aleatório . . . . . . . . . . . . . . . . . . . 136

E.3 Teste de Hausman . . . . . . . . . . . . . . . . . . . . . . . 136

Anexo F - Resultados Teste de Hausman — Ensaio II 137

F.1 Período 1980-2004 . . . . . . . . . . . . . . . . . . . . . . . 137

F.2 Período 2000-2008 . . . . . . . . . . . . . . . . . . . 137

Anexo G - Elasticidade-renda das importações para o período 1980-2004 138

Anexo H - Análise de ajustamento e causalidade de Granger para renda e exportações

- Brasil

H.1 Testes ADF -1 raiz unitária contra 0 raízes unitárias . . . . . . . . . . . . . . 139

H.2 Vetor de cointegração e testes de cointegração . . . . . . . . . . . . . . . . . 140

H.3 Testes sobre as variáveis de ajuste e Casualidade de Granger . . . . . . . . . . 143

H.4 Testes dos resíduos . . . . . . . . . . . . . . . . . . . . . 145 


\title{
Lista de abreviaturas e siglas
}

\author{
BCB Banco Central do Brasil \\ BNDES Banco Nacional Desenvilvimento Economico e Social \\ CEPAL Comissão Econômica para a América Latina e o Caribe \\ COMTRADE United Nations Commodity Trade Statistics Database \\ EXPY Renda associada à pauta exportadora \\ FIPE Fundação Instituto de Pesquisas Econômicas \\ IMPY Renda associada à pauta importadora \\ IPA Índice de Preços ao Atacado \\ IPC Índice de Preços ao Consumidor \\ IPEA Instituto de Pesquisas Econômicas Aplicadas \\ MQO Mínimos Quadrados Ordinários \\ NFSP Necessidade de financiamento do setor público \\ OCDE Organisation for Economic Co-operation and Development \\ P\&D Pesquisa e Desenvolvimento \\ PTF Produtividade Total de Fatores \\ PIB Produto Interno Bruto \\ PRODYM Índice que mede a renda média dos países que importam cada bem \\ PRODYX Índice que mede a renda média dos países que exportam cada bem \\ UNCTAD United Nations Conference on Trade and Development \\ VEC Vetor de correção de erros \\ WDI World Development Indicators
}




\section{Lista de Tabelas}

1.1 As quinze maiores e menores taxas de crescimento. . . . . . . . . . . . . . 22

2.1 Modelos de crescimento em economias abertas. . . . . . . . . . . . . . . . 41

2.2 Maiores e menores PRODYX. . . . . . . . . . . . . . . . . . 47

2.3 Maiores e menores PRODYM. . . . . . . . . . . . . . . . . . . 48

2.4 Maiores e menores EXPY . . . . . . . . . . . . . . . . . . . . . . . . . . 49

2.5 Maiores e menores IMPY. . . . . . . . . . . . . . . . . 50

2.6 Resultados do teste dos modelos exportação. . . . . . . . . . . . . . . . . . 52

2.7 Resultados do teste dos modelos importação. . . . . . . . . . . . . . . . 53

2.8 VEC, Equação Equilíbrio do BP. . . . . . . . . . . . . . . . . 56

2.9 Tabela UNCTAD . . . . . . . . . . . . . . . . . . . . . . . . . . 59

3.1 Resultados da estimação 2000-2008 . . . . . . . . . . . . . . . . . . 72

3.2 Resultados da estimação 1980-2004. . . . . . . . . . . . . . . . . . 73

3.3 Elasticidade-renda das importações. . . . . . . . . . . . . . . . . . . . . . 74

4.1 Resultados Fiscais. Fonte: elaboração própria/Ipea. . . . . . . . . . . . . . 86

4.2 Indicadores Externos. Fonte: Elaboração própria/Ipea. . . . . . . . . . . . . . . 87

4.3 Resultados elasticidade-renda das importações. Fonte: elaboração própria. . . . 90

4.4 Resultados elasticidade-renda das exportações. Fonte: elaboração própria. . . . 90

4.5 Coeficiente das estimações das equações do modelo. . . . . . . . . . . . . . 107

4.6 Efeito da quebra no parâmetro estrutural. . . . . . . . . . . . . . . . . . 107

4.7 Estimações do modelo e do Real. . . . . . . . . . . . . . . . . . . . . . . . . . 109 


\section{Lista de Figuras}

1.1 Renda per capita entre regiões. . . . . . . . . . . . . . . . . . . . . 12

1.2 Inflação ao consumidor. Fonte: World Bank (WDI) . . . . . . . . . . . . . . . 20

1.3 Taxas de juro internacionais. Fonte: World Bank (WDI). . . . . . . . . . . . 20

1.4 Medida de câmbio real. Fonte: World Bank (WDI). . . . . . . . . . . . . . . 21

1.5 PIB per capita. Fonte: World Bank (WDI) . . . . . . . . . . . . . . . . 21

1.6 PIB per capita. Fonte: World Bank (WDI) . . . . . . . . . . . . . . . . 22

1.7 Exportações de bens e serviços. Fonte: World Bank (WDI). . . . . . . . . . . . 23

2.1 PRODYX 2 dígitos. . . . . . . . . . . . . . . . . 45

2.2 PRODYM 2 dígitos. . . . . . . . . . . . . . . . . 46

2.3 PRODYX e PRODYM por produto. . . . . . . . . . . . . . . . 49

2.4 EXPY e IMPY por país. . . . . . . . . . . . . . . . 50

2.5 EXPY e renda per capita por país. . . . . . . . . . . . . . 51

2.6 EXPY e renda per capita por país. . . . . . . . . . . . . . . 51

2.7 Renda per capita e diversidade exportações. . . . . . . . . . . . . . . . . . 54

2.8 Crescimento e diversidade exportações. . . . . . . . . . . . . . . 55

3.1 Elasticidade-renda das importações e nível de renda (2000). . . . . . . . . . . . 74

3.2 Elasticidade-renda das importações e nível de renda (1980-2004). . . . . . . . 75

3.3 Elasticidade-renda das importações e crescimento. . . . . . . . . . . . . . 75

3.4 Elasticidade-renda das importações e crescimento (2000). . . . . . . . . . . . . 76

3.5 Qualidade das exportações e câmbio — China. . . . . . . . . . . . . . . 76

3.6 Elasticidade-renda das importações e IMPY . . . . . . . . . . . . . . . . . 77

3.7 Elasticidade-renda das exportações e EXPY . . . . . . . . . . . . . . . . 78 
4.1 Crescimento econômico brasileiro. . . . . . . . . . . . . . . . . . . 82

4.2 Produtividade. Fonte: Ipea. . . . . . . . . . . . . . . . . . . . . . . . . . 84

4.3 Política Monetária. Fonte: Ipea. . . . . . . . . . . . . . . . . . . . . . . . 85

4.4 Contas Nacionais. Fonte: Ipea. . . . . . . . . . . . . . . . . . . . . . . . . 86

4.5 Balança Comercial. Fonte: Ipea. . . . . . . . . . . . . . . . . . . 87

4.6 Qualidade da pauta exportadora. Fonte: elaboração própria. . . . . . . . . . . . 91

4.7 Qualidade da pauta importadora. Fonte: elaboração própria. . . . . . . . . . . . 91

4.8 Evolução da elasticidade-renda ponderada das exportações e importações e da razão de elasticidades ponderadas — Brasil 1964-2006. Fonte: Gouvêa e Lima

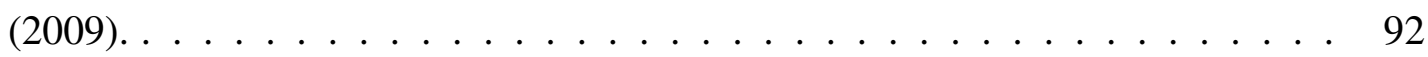

4.9 Exportações Brasileiras por país - 2000. Fonte: COMTRADE. . . . . . . . 93

4.10 Exportações Brasileiras por País - 2008. Fonte: COMTRADE. . . . . . . . . 93

4.11 Regimes macroeconômicos. . . . . . . . . . . . . . . . . . 102

4.12 Regimes macroeconômicos Kaldorianos. . . . . . . . . . . . . . . . 108

4.13 Termos de troca e câmbio real. Fonte: Ipea. . . . . . . . . . . . . . . 110

4.14 Simulação da trajetória de convergência. . . . . . . . . . . . . . . . 110

A.1 PRODYM e PRODYX 2 dígitos. . . . . . . . . . . . . . . . . . . 129 


\section{Lista de símbolos}

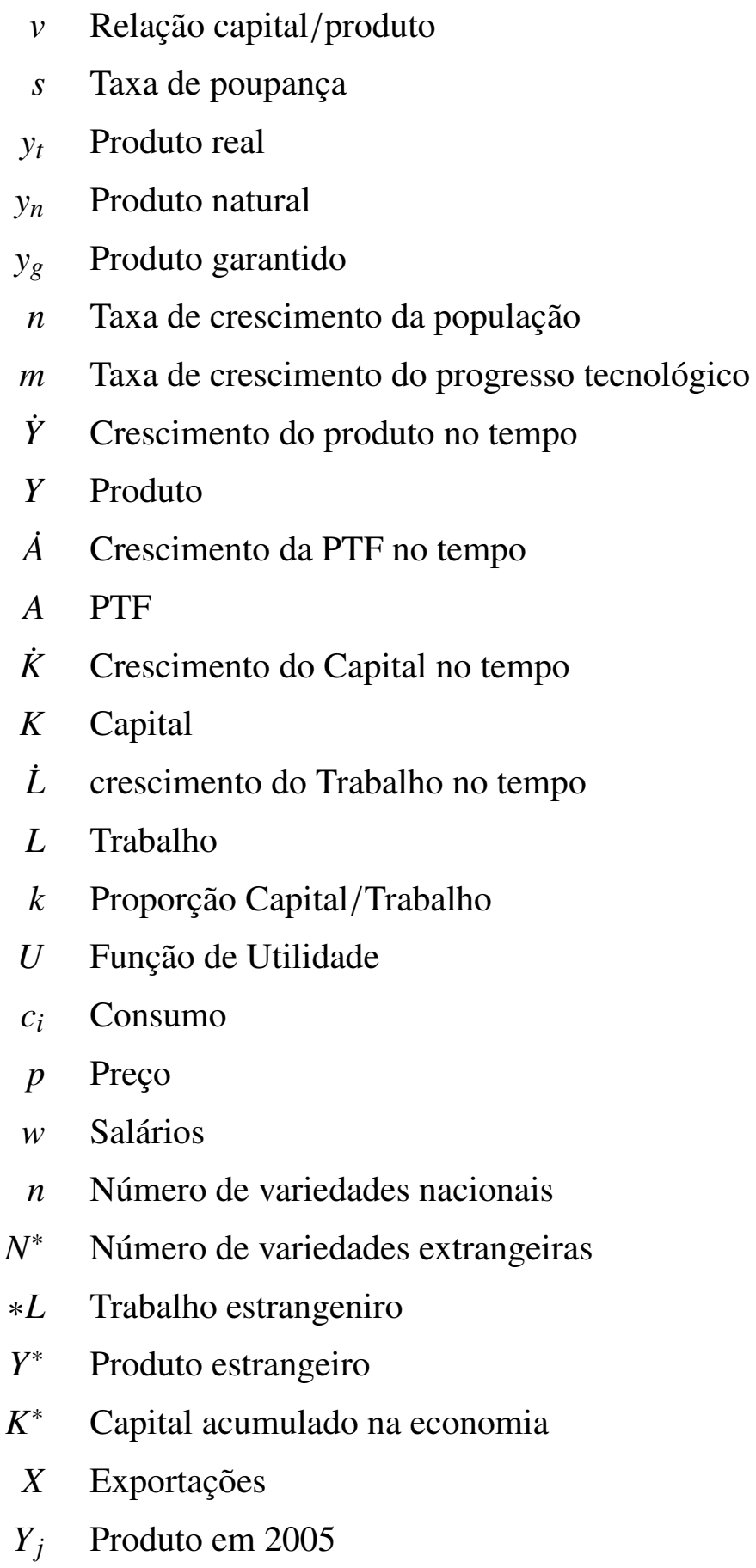


$\begin{aligned} x_{j k} & \text { Exportações em } 2005 \text { do produto } k \\ m_{j k} & \text { Importações em } 2005 \text { do produto } k \\ K-R & \text { Componente financeiro }\end{aligned}$

A Unctad - Commodities primárias

$B$ Unctad - Intensivos em trabalho

C Unctad - Manufaturas baixa tecnologia

D Unctad - Manufaturas média tecnologia

E Unctad - Manufaturas alta tecnologia

$F \quad$ Unctad - Outros

$\eta \quad$ Elasticidade preço das exportações

$\epsilon \quad$ Elasticidade renda das exportações

$\psi \quad$ Elasticidade preço das importações

$\pi \quad$ Elasticidade renda das importações

$E_{t} \quad$ Taxa de câmbio nominal

$F \quad$ Entrada de capital externo

I Investimento

$L_{i} \quad$ Produtividade produtos industriais

$L_{p} \quad$ Produtividade produtos primários

$M$ Importações

$P_{d} \quad$ Preço doméstico

$p_{d} \quad$ Aumento de preços internos

$P_{f} \quad$ Preço externo

$p_{f} \quad$ Aumento de preços externos

$P_{p} \quad$ Preço produtos primários

$P_{i} \quad$ Preço produtos industriais

$R$ Pagamento de serviços fatores

$X$ Exportações

$\dot{y}$ Taxa crescimento produto

$Y \quad$ Renda Interna

$y_{b p} \quad$ Taxa de crescimento compatível com o equilíbrio do Balanço de Pagamentos

$Y_{r} \quad$ Relação entre rendas produtos primários e industriais

$Z$ Renda externa 
$z_{t} \quad$ Taxa de crescimento da renda externa

$x \quad$ Taxa de crescimento das exportações

$m$ Taxa de crescimento das importações

$f-r \quad$ Taxa de crescimento do componente financeiro

$e \quad$ Ttaxa de crescimento do câmbio

$\theta \quad$ Fraçao das exportações na receita

$C_{i} \quad$ Efeito fixo

$q$ Taxa de crescimento da produtividade

$r$ Componente exógeno da produtividade

$\alpha \quad$ Coeficiente de Verdoorn

c Taxa de crescimento do consumo

$i$ Taxa de crescimento do investimento

$c_{0} \quad$ Consumo autônomo

$i_{0} \quad$ Investimento autônomo

$\lambda$ Variação consumo-renda

$i \quad$ taxa de juros

$\sigma \quad$ prêmio de risco

$\theta_{1} \quad$ Elasticidade-investimento da renda

$\theta_{2}$ Elasticidade-investimento do câmbio

$\tau$ Variação na taxa de mark-up 


\section{Introdução: o estudo do crescimento econômico e a conjuntura dos anos 2000}

Como bem colocam Barro e Sala-i-Martin (2004), a taxa de crescimento de longo prazo tem-se mostrado um fator mais importante para o bem estar da humanidade do que os tão estudados problemas de ciclos econômicos. A renda per capita dos EUA, por exemplo, era de US\$ 3.340 em 1870 e passou a US\$33.330 em 2000, tornando-se a segunda maior renda per capita mundial (após o pequeno país de Luxemburgo). Isso correspondeu a uma taxa anual média de crescimento de $1,8 \%$. Se a economia americana tivesse crescido a uma taxa de $0,8 \%$, próximo à performance da Índia, a renda per capita em 2000 seria de US\$9.450 e os EUA seriam, ao invés de segundo, $45^{\circ}$ colocado em um ranking de 150 países. Na mesma direção, Lucas (1988) ressalta que, "se existe alguma ação governamental que pode aumentar o crescimento de longo prazo, qual é? Se não há, qual a natureza do país que determina o seu crescimento? As consequências para o bem estar da humanidade, envolvidas nessa questão são tão importantes que quando se começa a pensar nelas é difícil pensar em algo mais." Um exemplo da importância do assunto se explicita quando se verifica as diferenças de renda per capita entre países e constata-se que existem países com patamar de renda de US\$100 por ano e países com patamar de renda de US\$ 60.000 por ano. Não é apenas um problema de diferenças superficiais de bem estar; trata-se de países cuja população não tem o mínimo para a sobrevivência em contraste com outros países, cujo o padrão de vida é realmente elevado. Por todos esses motivos, o estudo do desempenho econômico de longo prazo deve ser um dos maiores motivadores de pesquisa em teoria econômica.

Pela própria relevância do assunto, a questão inicial tratada pela ciência econômica foi exatamente uma Investigação sobre a Natureza e a Causa da Riqueza das Nações, obra de Adam Smith publicada em 1776 (SMITH, 1999). Deane (1980) classifica como economia moderna aquela que se inicia no século XVIII com os trabalhos dos fisiocratas franceses e de Smith (1999). Esses trabalhos culminam no surgimento, já no século XIX, da Economia Política como campo 


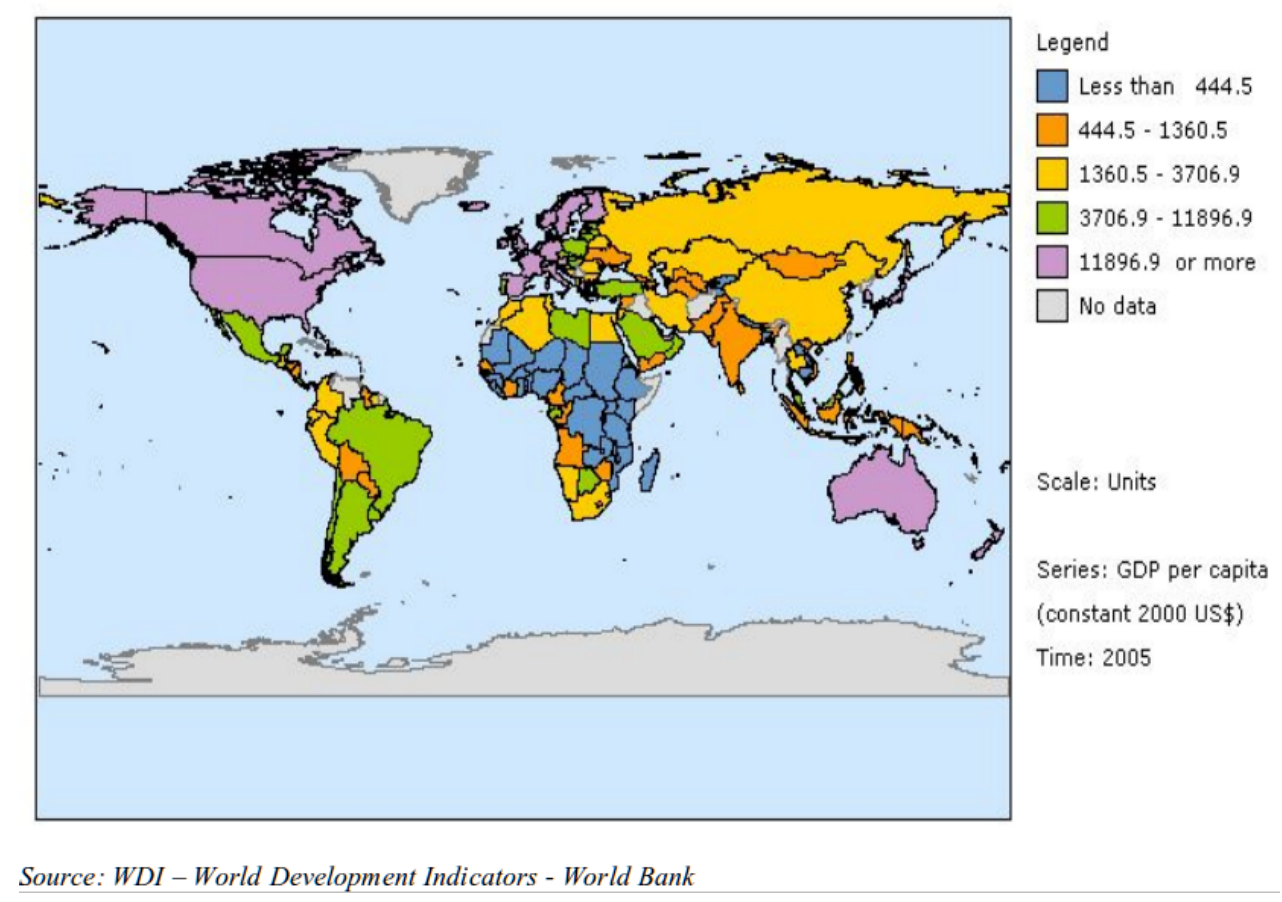

Figura 1.1: Renda per capita entre regiões.

de estudo autônomo, a partir, principalmente, dos trabalhos de Say publicados em 1803 (SAY, 1983) e dos Princípios de Economia Política de John Stuart Mill, publicado em 1848 (MILL, 1996). Desta maneira, pode-se identificar a origem das teorias de crescimento econômico já nos primórdios da nova disciplina, ou seja, nos trabalhos dos fisiocratas franceses e de Adam Smith.

O interesse dos fisiocratas franceses já consistia em entender a dinâmica do produto total da economia, assim como identificar seus principais determinantes. Quesnay, em seu Tableau Economique de 1759 (QUESNAY, 1972), por exemplo, buscou demonstrar como as despesas em um setor geravam rendas em outros setores. No sistema fisiocrata existia apenas uma classe social que gerava excedente econômico, ou seja, um produto maior que o necessário para pagar os custos envolvidos na sua produção: a classe dos agricultores. Esse excedente econômico gerado na agricultura dava origem aos avances, ou seja, gastos com capital dos quais provinha o produto do próximo período.

$\mathrm{Na}$ teoria de Adam Smith, o crescimento econômico tinha duas causas: a divisão do trabalho, que gerava aumentos de produtividade do trabalho, e a extensão do mercado que induzia a acumulação de capital (conceito análogo à dos fisiocratas franceses, porém inclui-se o setor manufatureiro como setor produtivo, ou seja, gerador de excedente econômico). Segundo Foley e Michl (1999) "o aumento da divisão do trabalho e a extensão do mercado são tendências que se reforçam já que um maior mercado torna possível uma maior divisão do trabalho, aumentando a produtividade e encorajando investimento." Smith argumentava que o processo seria 
bom para capitalistas que aumentariam suas possibilidades de lucros, mas também para trabalhadores, uma vez que o salário cresce em função do aumento da demanda de trabalho. Esse otimismo não era compartilhado por Malthus (1799), ${ }^{1}$ que acreditava que o aumento do salário real causaria um aumento de população, o qual aumentaria a oferta de trabalho e o salário voltaria a seu nível natural.

Já no século XIX, a constituição da Economia Política como campo de pesquisa específico permitiu que as teorias de crescimento econômico ganhassem um fim em si mesmo. Ou seja, o objetivo passava a ser propriamente o entendimento da lógica do processo dinâmico de crescimento econômico. Nesse sentido, podemos ressaltar um ponto em comum entre as teorias clássicas de crescimento: o movimento inevitável de uma economia em direção a um estado estacionário. Assim, na teoria clássica de crescimento, exposta no livro On the Principles of Political Economy and Taxation de David Ricardo, publicado em 1817 (RICARDO, 1951), por exemplo, a economia se expandirá enquanto os recursos naturais (como, por exemplo, a terra) forem abundantes, pois o capital será atraído pelas novas oportunidades de lucro em recursos ainda não explorados, e a mão de obra crescerá em resposta a essa demanda. Porém, como os recursos naturais têm uma oferta fixa e a quantidade de mão de obra aumenta quando o salário está acima do nível natural, o aumento dos salários totais tende a comprimir os lucros totais. $\mathrm{O}$ processo continua até que a parcela de lucros chegue à zero, e, portanto, acabará o estimulo à acumulação de capital, levando a economia à estagnação. Nesse sentido, o aumento da produtividade do trabalho pode retardar, mas, a princípio, não pode reverter essa dinâmica.

O Capital de Karl Marx, publicado em 1867 (MARX, 1985), introduziu o progresso tecnológico endógeno ao sistema como sendo o elemento que contribuiria para diminuir a tendência à queda da taxa de lucro. No entanto, o aumento progressivo da razão capital/trabalho, fruto da mudança tecnológica progressiva, reconduziria à tendência de queda da taxa de lucro, provocando a estagnação do sistema.

Em todas as teorias mencionadas até aqui, de uma forma ou de outra, acabava emergindo a questão de como mensurar os agregados, ou seja, como medir o valor da mercadoria e, assim, as teorias acima embasavam-se na Teoria do Valor Trabalho, ou seja, o valor de uma mercadoria era o valor do trabalho embutido nela. Entretanto, ainda que sobre outro paradigma científico, questões centrais de crescimento econômico já haviam sido colocadas, tais como: produtividade do trabalho, acumulação de capital, progresso tecnológico, extensão de mercado.

Foi o advento da Revolução Marginal, sobretudo a partir das obras de Walras, ${ }^{2}$ Menger $^{3}$

\footnotetext{
${ }^{1}$ Ensaio sobre o Princípio da População (MALTHUS, 1982).

${ }^{2}$ Elementos de Economia Politica Pura, de 1874 (WALRAS, 1996).

${ }^{3}$ Investigations into the method of the social sciences with special reference to economics de 1883 (MENGER,
} 
e Jevons, ${ }^{4}$ e a consolidação da teoria neoclássica, que modificou a questão central da teoria econômica, concentrando a análise na alocação eficiente de recursos econômicos. Na verdade, como bem coloca Deane (1980), "a teoria do crescimento econômico não constituiu uma área promissora para aplicação das técnicas marginais de analise.” Isso decorre do simples fato de que a teoria neoclássica mudou o cerne da questão econômica. Ou seja, tirou o foco dos determinantes do crescimento e da distribuição do produto como um todo e concentrou-se na alocação ótima de recursos escassos dados. Como o estudo do crescimento procura exatamente explicar como se determina esses dados recursos, e não, uma vez dados, como são alocados, a teoria do crescimento não frutificou no ambiente que se seguiu à consolidação da ortodoxia neoclássica.

Foi com o advento da revolução keynesiana nos anos de $1930,{ }^{5}$ em um cenário de depressão mundial, que a questão da determinação do nível de renda e do crescimento do produto ressurge como uma das questões mais relevantes, dado o cenário econômico desfavorável. Neste cenário, e com forte influência keynesiana, surgiu o primeiro modelo macroeconômico moderno de teoria de crescimento: o Modelo Harrod. ${ }^{6}$

Segundo Sen (1970), Harrod estava interessado na possibilidade de um crescimento estacionário em um modelo com uma taxa fixa de capital/produto $(v)$ e de Poupança/Produto $(s)$. Assim, uma unidade de capital vai produzir $1 / v$ unidades de produto que gerará $s / v$ unidades de poupança líquida e de crescimento do estoque de capital. Como o produto é proporcional ao capital, essa seria a taxa de crescimento do produto. Essa taxa garantida de crescimento $\left(y_{g}\right)$ deveria igualar-se à taxa efetiva de crescimento $\left(y_{t}\right)$ no longo prazo. Entretanto, Harrod (1933) argumentou que o processo era instável, já que só por acidente essa taxa garantida de crescimento $\left(y_{g}\right)$ igualar-se-ia à taxa de crescimento da população $(n)$ somada ao aumento da produtividade do trabalho $(m)$, soma essa que Harrod denominou de taxa natural $\left(y_{n}\right)$.

Assim, a partir das ideias contidas em Harrod (1933) e em Domar (1947), formalizou-se uma versão que ficou conhecida na literatura como modelo Harrod-Domar. Dessa forma, no longo prazo:

$$
y_{t}=y_{g}=s / v=y_{n}=n+m
$$

Ou seja,

$$
s / v=n+m
$$

O problema é que todos os componentes da fórmula são parâmetros, e, portanto, não existe 1985).

${ }^{4}$ Theory of Political Economy de 1871 (JEVONS, 1911).

${ }^{5}$ A partir da A Teoria Geral do Emprego, do Juro e da Moeda de Keynes, publicada em 1936 (KEYNES, 1992).

${ }^{6}$ International Economics, publicado de 1933 (HARROD, 1933). 
mecanismo de ajuste. Se $s / v<n+m$ ou $s / v>n+m$, não existe nenhum mecanismo endógeno que faça a economia voltar à situação de equilíbrio. Chega-se, dessa forma, a um sério problema de instabilidade nas economias capitalistas. No entanto, o fato estilizado de que as economias não tendem à extinção ou explosão, ou seja, de que existe uma certa estabilidade no sistema, deixava questões em aberto sobre os resultados do modelo Harrod-Domar.

Uma das soluções da controvérsia deixada por Harrod (1933) veio com o Modelo de Solow (SOLOW, 1956). Segundo Sen (1970), além da atração que vem de sua "bonita simplicidade," a maior contribuição de Solow (1956) foi a de colocar de maneira inovadora a questão do crescimento econômico dentro do universo neoclássico. Ou seja, o problema da alocação e do crescimento juntaram-se num modelo de extrema simplicidade analítica: o parâmetro $(v)$, ou seja, a técnica de produção (relação capital/produto), transformou-se em uma variável de ajuste. Construiu-se uma função de produção agregada, onde capital e trabalho são insumos de produção e podem ser substituídos em qualquer proporção dada pela tecnologia. Ou seja, capital e trabalho combinam-se no processo produtivo. O problema do crescimento econômico é transformado em um problema de alocação ótima de capital e trabalho a pleno emprego de ambos, tornando-o tratável em bases neoclássicas.

Entretanto, entre 1930 e 1950, enquanto esse debate dos modelos de crescimento ocorria para as economias centrais, em nenhum dos modelos o fato de as economias estarem ou não abertas ao comércio internacional, estarem ou não no mesmo nível de industrialização dos parceiros comerciais, colocava-se como uma variável relevante. Porém, neste período, diversas economias periféricas estavam se industrializando tardiamente e comerciando com centros industriais. Esse foi um impulsor para os modelos desenvolvimentistas que visavam entender especificamente o processo de desenvolvimento nessas economias sub-desenvolvidas, literatura que se produziu à margem do mainstream da teoria econômica.

Segundo Hirschman (1981), as teorias de desenvolvimento estão baseadas em dois ingredientes econômicos básicos: a rejeição da "monoeconomia" e a aceitação de "benefício mútuo". Ou seja, os autores desenvolvimentistas rejeitavam a monoeconomia, já que acreditavam que os países subdesenvolvidos eram um grupo que deveria ser estudado à parte, pois tinham características próprias que os distinguiam dos países desenvolvidos. Por outro lado, os autores desenvolvimentistas não rejeitavam a possibilidade de se poder reconstruir a relação entre os países desenvolvidos e subdesenvolvidos de modo que ambos fossem beneficiados. Em outras palavras, existiria uma solução para os países subdesenvolvidos sem romper a estrutura capitalista.

Ainda segundo Hirschman (1981), a rejeição da monoeconomia exige a criação de uma 
estrutura teórica separada que explique por que grande parte da teoria convencional não funciona para países pobres e qual o instrumental que pode-se utilizar para estudar estes países. Nesta linha surgiram diversos trabalhos como o de Lewis, publicado em 1954 (LEWIS, 1969), que foca na abundância de mão de obra nos países subdesenvolvidos, o que invalidaria a hipótese neoclássica de que a taxa de salário se equivale à produtividade marginal do trabalho. Já o trabalho de Rosenstein-Rodan (1943) foca na questão da economia de escala intrínseca ao processo de industrialização e sugere que o governo lidere este processo. Nesta mesma área de pesquisa podemos ainda ressaltar o estudo de Hirschman (1961) sobre desequilíbrios incentivando o crescimento, já que essas economias não tem instituições favoráveis à tomada de decisão, processo esse que só ocorre sobre a pressão de algum desequilíbrio; Myrdal (1957) e o processo de causação cumulativa circular, cujo foco são as relações estabelecidas entre espaços desequilibradamente desenvolvidos, que acarretariam uma trajetória de crescente agravamento das disparidades nos níveis de desenvolvimento; e Nurkse (NURKSE, 1953; NURKSE, 1961) e sua teoria de crescimento balanceado com seu importante impacto no planejamento do desenvolvimento através de um bloco de investimentos que retiraria os países pobres do ciclo vicioso entre capitalização e crescimento da produtividade.

Finalmente, podemos destacar os trabalhos de Prebisch de 1949 (PREBISCH, 2000) e da CEPAL, que focaram na heterogeneidade estrutural dos países subdesenvolvidos e na questão da transferência de renda desses para os países desenvolvidos através do setor externo. Nesse modelo, as raízes históricas das nações condicionaram sua participação na divisão internacional do trabalho e as características de suas estruturas produtivas. A industrialização espontânea que se inicia nos anos 30, ao penetrar em uma estrutura especializada e heterogênea, fruto de uma divisão do trabalho em que a periferia era exportadora de produtos primários, faz com que, durante a industrialização, perdurem os problemas de balanço de pagamentos e de desemprego estrutural inerentes à estrutura periférica. A periferia continua a transferir recursos para o centro, seja através de preços (deterioração dos termos de troca), seja através de quantidades (elasticidades de comércio exterior desfavoráveis que levam a um crescimento maior no centro do que na periferia).

Apesar de marginalizadas pelo mainstream econômico, seu caráter mais realista e mais próximo dos problemas reais e específicos enfrentados pelas economias subdesenvolvidas fizeram com que os "policy makers," embasados nessas teorias, operassem para reverter esse quadro desfavorável, induzindo a industrialização nas economias periféricas. Em outras palavras, esse conjunto de ideias teve mais influência sobre os police-makers dos países em desenvolvimento nesse período do que qualquer teoria do crescimento jamais experimentou. 
A crise internacional dos anos 1970-1980, aliada à industrialização dos países periféricos e aos problemas que a industrialização não resolveu, de certa forma congelou esse tipo de análise mesmo na periferia e o mainstream da teoria de crescimento à la Solow voltou propondo um grau de abrangência geral. O modelo sobreviveu à transformação macroeconômica provocada pela crítica de Lucas (1976). Assim, uma extensão importante ao trabalho de Solow foi o trabalho desenvolvido por Cass (1965), que endogeneiza da taxa de poupança ( $s$ ) através da analise de Ramsey da maximização intertemporal da utilidade do consumidor racional, atendendo à demanda de microfundamentação da nova tradição neoclássica.

No Modelo de Solow, no longo prazo e em estado estacionário, a taxa de crescimento do produto iguala-se à taxa de crescimento da população somada à taxa de crescimento da produtividade, que é considerada exógena no modelo. Desde o trabalho pioneiro de Solow (1957), o objetivo era decompor empiricamente o produto na contribuição de cada fator: capital físico, trabalho e tecnologia. Formalmente:

$$
\frac{\dot{Y}}{Y}=\frac{\dot{A}}{A}+\alpha(t) \frac{\dot{K}}{K}+(1-\alpha(t)) \frac{\dot{L}}{L}
$$

Como A é o insumo desconhecido no resíduo, intitulado Produtividade Total de Fatores, a decomposição é feita da seguinte forma:

$$
\frac{\dot{A}}{A}=\frac{\dot{Y}}{Y}-\left[\alpha(t) \frac{\dot{K}}{K}+(1-\alpha(t)) \frac{\dot{L}}{L}\right]
$$

Solow (1957) utiliza o estudo para dados americanos e verifica que a produtividade total de fatores $(A)$ explicava $87,5 \%$ do crescimento do produto, enquanto o capital explicava os demais $12,5 \%$. Outros testes empíricos citados em Barro e Sala-i-Martin (2004) mostraram que, para um modelo de Solow básico, a PTF, ou o resíduo, explicava por volta de 50\% do crescimento. Ou seja, a variável exógena denominada Produtividade Total de Fatores, que é na verdade um resíduo do modelo, explicava a maior parte do modelo.

Com base na crítica da exogeneidade da produtividade, surgiram uma série de modelos que procuraram endogeneizar o progresso tecnológico através de diferentes canais. O principal mecanismo para obter um crescimento endógeno é não permitir retornos decrescentes em algum dos fatores acumuláveis. Entre esses modelos pode-se destacar o modelo AK (FRANKEL, 1962), que retirou o retorno decrescente do capital, o modelo de learning by doing (ARROW, 1962), o modelo de P\&D de Romer (1990), e modelos de capital humano de Lucas (1988), entre outros. Esses modelos de crescimento endógeno tiveram seu auge no final dos anos 1980 e nos anos 1990. Entretanto, a dificuldade de testá-los empiricamente, a não-verificação empírica de 
vários de seus preceitos, como por exemplo a relevância dos gastos em $\mathrm{P} \& \mathrm{D}$, assim como fatores não conhecidos, próprios da evolução das ideias econômicas, os levaram à margem da Teoria do Crescimento. Mas eles, principalmente Romer (1990) e Lucas (1988), deixaram um legado: a importância de um setor de ideias na contabilidade do crescimento que depois se tornaria o capital humano.

Nesse sentido, o trabalho de Mankiw, Romer e Weil (1992) retomou Modelo de Solow como o principal instrumental analítico para tratar a questão do crescimento, introduzindo uma medida do capital humano. Os autores conseguiram melhorar significativamente o poder explicativo do modelo de Solow, diminuindo o resíduo (PTF) para cerca de $20 \%$.

A partir de então, o modelo de Solow original com capital humano voltou a ser o modelo de crescimento mais aceito pela ortodoxia dominante. Entretanto, surge uma nova controvérsia: autores como Mankiw, Romer e Weil (1992), Lucas (1988), entre outros, acreditam que a introdução do capital humano explica grande parte do crescimento do modelo.

Esses dados são rejeitados por Hall e Jones (1999), Klenow e Rodriguez (1997), Ferreira, Pessoa e Velloso (2005) e Islam (1995), já que seus resultados apontam que a Produtividade Total de Fatores (PTF) é a principal causa do crescimento e a investigação relevante é o que comporia a Produtividade Total de Fatores.

$\mathrm{Na}$ verdade, os dados são extremamente sensíveis à medida de capital humano adotada. Entretanto, de uma maneira geral, pode-se dizer que grande parte da discussão do mainstream em relação ao crescimento no final da década de 1990 e na década de 2000 focou-se em verificar se o capital humano explicava produto e diferenças de renda, ou se a PTF era o elemento dominante. Os que concluíram que PTF era o fator primordial para explicar produto e diferença de renda caminharam no sentido de investigar as diferenças entre as PTFs. O curso que alguns autores trilharam foi o de investigar as diferenças de instituições e as raízes históricas do processo de desenvolvimento, provocando o surgimento de trabalhos como o de Acemoglu, Johnson e Robinson (2001) que, baseados em variáveis instrumentais, estabelecem uma relação entre as instituições coloniais e o nível de produto atual. Outro curso, trilhado por alguns autores como Aghion e Howitt (1992), recorreu a modelos shumpeterianos para investigar as inovações tecnológicas.

Assim, pode-se dizer que neste ponto se encontra o mainstream do estudo sobre o crescimento econômico na década de 2000: de um lado os que acreditam que as diferenças de renda podem estar associadas essencialmente ao capital humano, de outro lado os que admitem que o resíduo (PTF) explica a maior parte do crescimento, e os que estão nesta linha buscam modelos histórico-institucionais ou modelos de inovações tecnológicas para explicar as diferenças 
de PTF.

Entretanto, pouco se encontra no mainstream do estudo sobre os determinantes do crescimento das nações, as ideias de diferenciais na competitividade externa fruto de estruturas produtivas desiguais. Alguns trabalhos nessa linha tem sido conduzidos por Hausmann, Hwang e Rodrik (2005) e Hausmann e Rodrik (2006); e é compatilhando dessa preocupação com a competitividade externa que se produziu este trabalho, ainda que a mesma faça uso de canais de propagação mais amplos que os colocados por esses autores.

A década de 2000 foi extremamente importante do ponto de vista de posicionamento no mercado internacional, e esse reposicionamento mudou a trajetória de crescimento de países como a China, a Índia e dos países mais ricos. Ou seja, a posição no mercado internacional afetou diretamente o desempenho das economias na década de 2000 e, portanto, é a principal razão para ser essa a periodicidade de estudo desta tese.

A maior importância do posicionamento no mercado internacional, nesta década específica, provavelmente deve-se às bruscas transformações ocorridas nas décadas anteriores no mercado internacional. Após a queda do muro de Berlim (1989), diversas economias do antigo bloco socialista entraram no mercado internacional. Mesmo economias que ainda são comunistas, como a China, estão atuando no mercado internacional. A América Latina abriu sua economia e hoje participa livremente do mercado internacional. Parte da Ásia, que já estava aberta ao mercado internacional, continua com sua estratégia de crescimento baseado nas exportações. $\mathrm{Ou}$ seja, novos agentes entraram no mercado internacional e procuram consolidar sua participação.

Uma vez justificada a escolha do período, importa fazer uma breve contextualização histórica da década. A década de 2000 foi relativamente estável e próspera até a grave crise financeira internacional no final de 2008 (crise que tiraremos do nosso período de análise). A Economia mundial dobrou de tamanho de US\$30,21 para US\$60,59 trilhões. Esse crescimento ocorreu num cenário de baixa inflação e baixos juros internacionais.

No entanto, o mais interessante da década era o que ocorria entre as nações. Assim, pode-se afirmar que o fato mais significativo nos anos 2000 foi o despertar das potências econômicas como a China e a Índia, que tiveram um crescimento de dois dígitos durante quase toda a década. Porém, essa inserção no mercado não foi aleatória ou guiada por vantagens comparativas, foi extremamente planejada e guiada por um Estado forte e não democrático. Esses países utilizaram-se em larga escala de mecanismos macro (cambiais) e micro (políticas industriais). Os investimentos em capital humano nessas duas potencias nitidamente ocorreram, mas esses países ainda não tem capital humano comparável ao dos países desenvolvidos. Assim, suas evoluções, ao menos nessa década, estão diretamente correlacionadas a suas inserções no mercado 


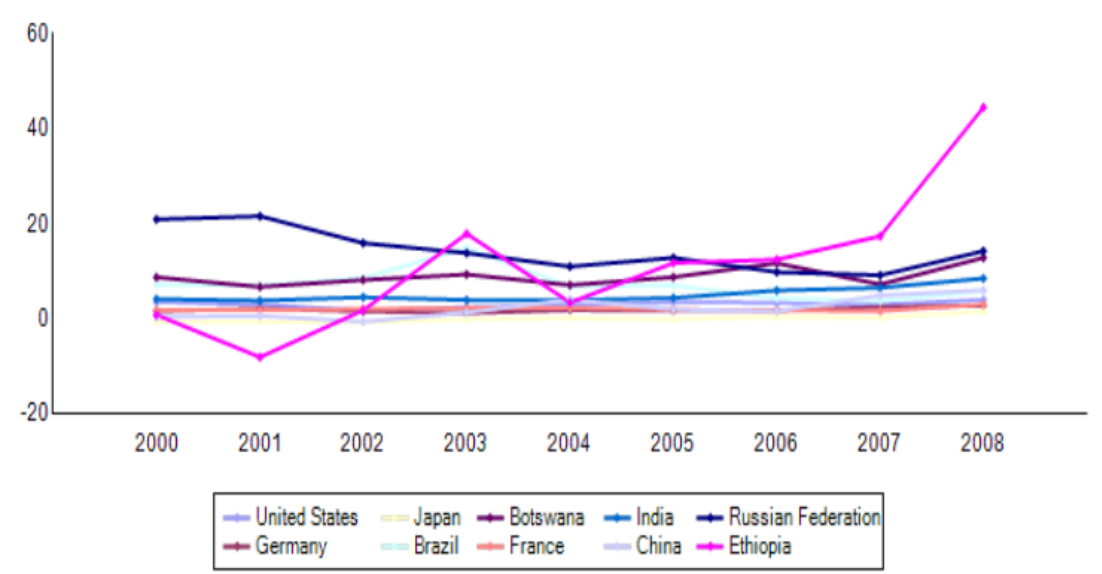

Figura 1.2: Inflação ao consumidor. Fonte: World Bank (WDI).

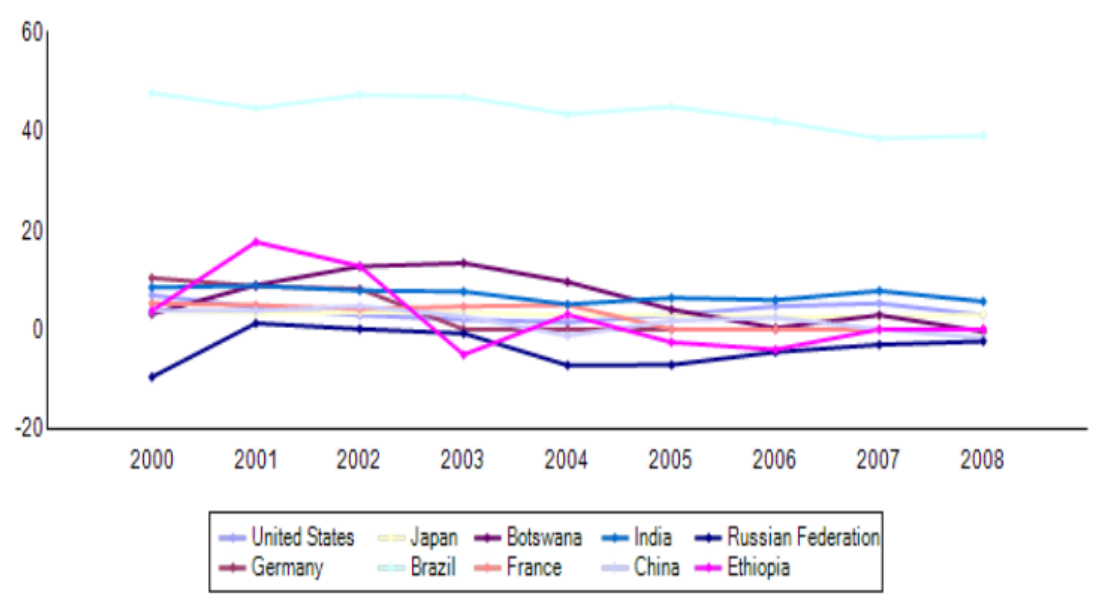

Figura 1.3: Taxas de juro internacionais. Fonte: World Bank (WDI).

internacional.

Segundo o Banco Mundial, em 2008, os Estados Unidos (US\$14,2 trilhões) mantiveram sua posição de maior economia do mundo. No entanto, o tamanho da sua contribuição para a economia mundial total passou de $28,8 \%$ para 23,4\%. O Japão (US\$4,9 trilhões) manteve sua posição de segunda maior economia do mundo, mas sua contribuição para a economia mundial caiu significativamente de $14,5 \%$ para $8,1 \%$. A China (US\$ 4 trilhões) passou de sétima maior para terceira maior economia e, em 2008, contribuiu com 7,1\% da economia do mundo comparado a 3,3\% em 1999. Alemanha (US\$ 3,65 trilhões), França (US\$2,85 trilhões), GrãBretanha (US\$2,65 trilhões) e Itália (US\$2,29 trilhões) foram a quarta, quinta, sexta e sétima maiores economias, respectivamente. O Brasil (US\$1,61 trilhões) manteve sua posição como oitava maior economia, seguida de perto pela Rússia (US\$1,607 trilhões) que pulou de $16^{\mathrm{a}}$ para $9^{\text {a }}$ e Espanha (US\$ 1,604 trilhões), que se manteve em décimo.

A remoção das barreiras comerciais e de investimento, o crescimento dos mercados inter- 


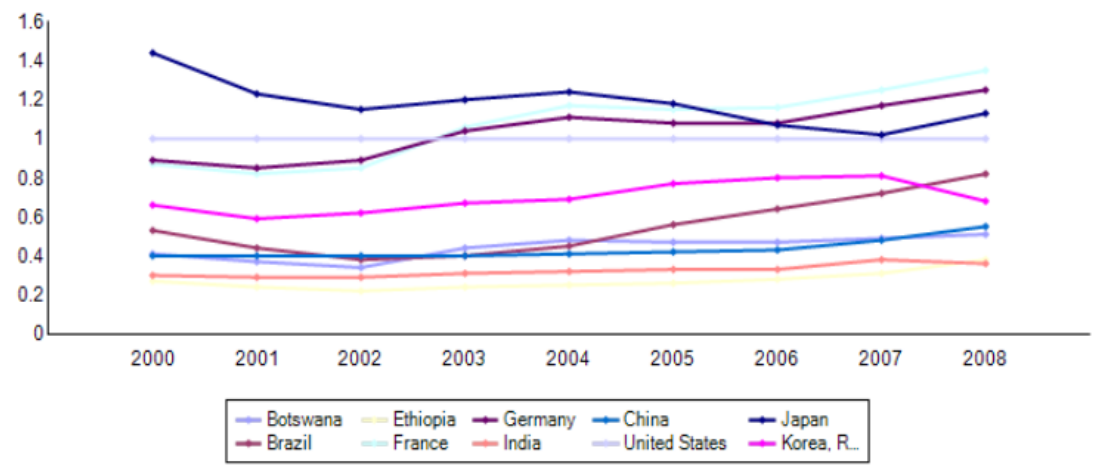

Figura 1.4: Medida de câmbio real. Fonte: World Bank (WDI).

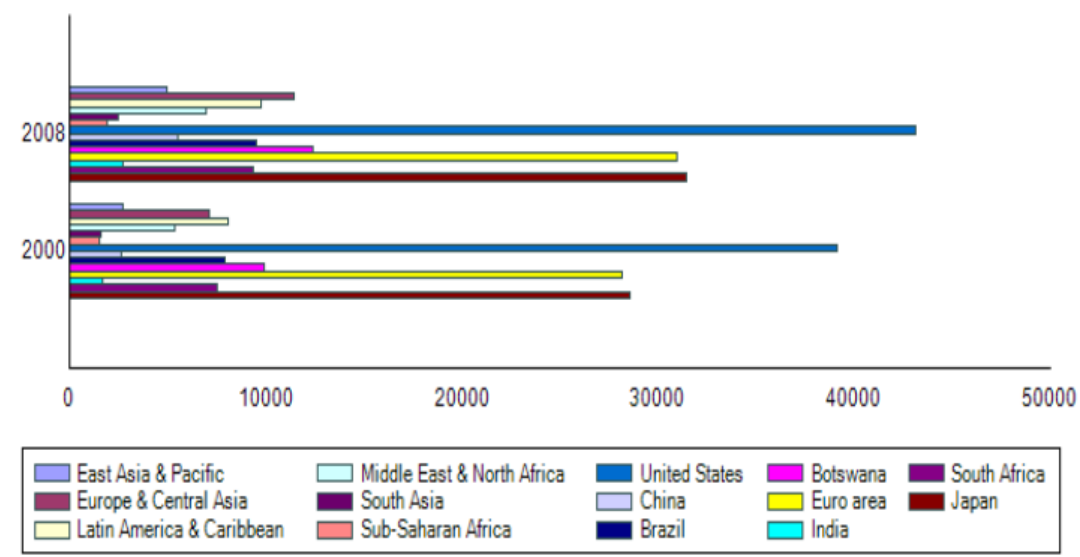

Figura 1.5: PIB per capita. Fonte: World Bank (WDI).

nos, as moedas artificialmente baixas, a proliferação da educação, o desenvolvimento rápido da alta tecnologia e da informação, os sistemas de indústrias e o crescimento da economia mundial levam a um crescimento significativo da terceirização na década, com muitas empresas multinacionais aumentando significativamente a subcontratação de fábrica (e cada vez mais, de serviços) através das fronteiras nacionais dos países em desenvolvimento, e particularmente na China e na Índia, devido aos muitos benefícios e principalmente porque os dois países estão com baixos custos. Como resultado deste crescimento, muitos destes países em desenvolvimento acumularam capital e começaram a investir no estrangeiro.

Outros países, incluindo os Emirados Árabes Unidos, Austrália, Brasil e Rússia, beneficiaramse do aumento na demanda de seus recursos minerais e de energia que gerou o crescimento global. Esse cenário foi sentido negativamente no Japão e partes dos Estados Unidos e na Europa, que não tinham sido capazes de desenvolver indústrias inovadoras bem-sucedidas. Como resultado, muitos postos de trabalho de serviço ao cliente, bem como trabalhos nos setores de tecnologia de informações (processamento de dados, programação de computadores e suporte técnico), em países como os Estados Unidos e o Reino Unido, foram potencialmente afetados. 


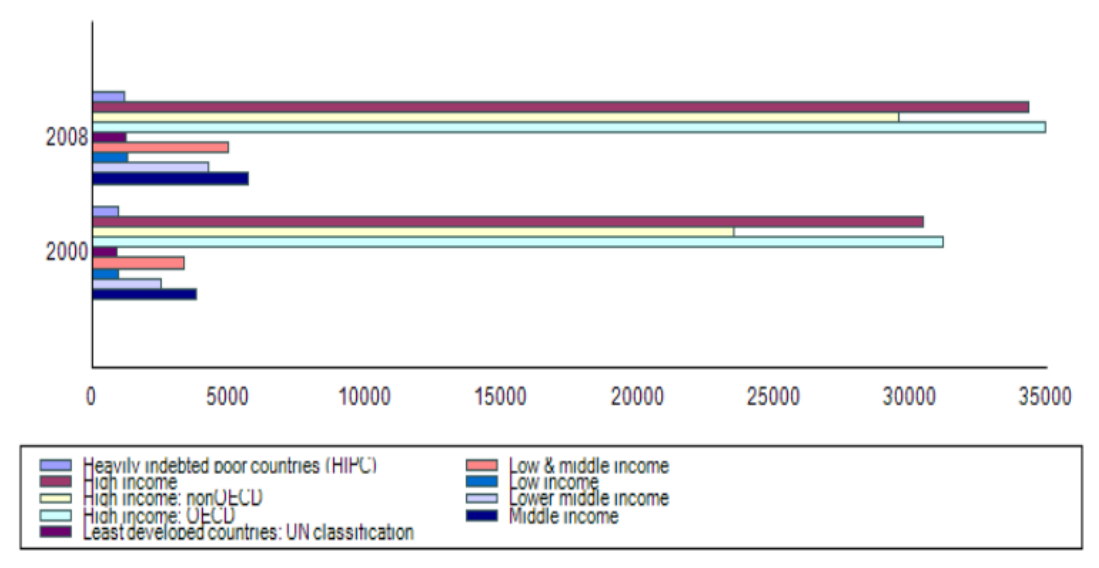

Figura 1.6: PIB per capita. Fonte: World Bank (WDI).

Tabela 1.1: As quinze maiores e menores taxas de crescimento.

\begin{tabular}{rlr|rllr}
\hline \multicolumn{5}{c}{ Crescimento médio 2000-2008 } \\
\hline \multicolumn{4}{c}{ Maiores taxas } & \multicolumn{3}{c}{ Menores taxas } \\
\hline 1 & Azerbaijão & 16,62 & 1 & Zimbábue & $-5,75$ \\
2 & Macao, China & 13,69 & 2 & Guiana & 0,06 \\
3 & Armênia & 11,20 & 3 & Costa do Marfim & 0,10 \\
4 & China & 9,99 & 4 & Fiji & 0,86 \\
5 & Cazaquistão & 9,39 & 5 & Itália & 1,04 \\
6 & Butão & 8,91 & 6 & Portugal & 1,20 \\
7 & Bielorrússia & 8,01 & 7 & Jamaica & 1,33 \\
8 & Emirados Árabes & 7,86 & 8 & Alemanha & 1,45 \\
9 & Sudão & 7,84 & 9 & Japão & 1,46 \\
10 & Trinidad e Tobago & 7,84 & 10 & Guiné-Bissau & 1,52 \\
11 & Etiópia & 7,55 & 11 & Kiribati & 1,54 \\
12 & Vietnã & 7,47 & 12 & Seychelles & 1,56 \\
13 & Moçambique & 7,36 & 13 & Dinamarca & 1,65 \\
14 & Latvia & 7,28 & 14 & Gabão & 1,74 \\
15 & Índia & 7,19 & 15 & França & 1,87 \\
\hline \multicolumn{4}{r}{} & Fonte: World Bank (WDI). &
\end{tabular}

A Figura 1.7, de exportações, explicita melhor a luta por mercados nesta década e as transformações da competitividade entre países.

Assim, tendo em vista a importância da competitividade externa no desempenho das nações na década de 2000, surge espaço para um trabalho como este, que, resgatando aspectos desenvolvimentistas, analisará o papel da competitividade externa, e o resultado desta inserção no mercado internacional na criação de ciclos virtuosos de crescimento que se espalham por diversas variáveis econômicas, podendo representar, para algumas nações, um processo de desenvolvimento.

Para atingir esse objetivo, esta tese inclui três ensaios e um capítulo de considerações finais. O primeiro ensaio constrói índices de competitividade da pauta exportadora e importadora para um total de 143 países com base em 1240 produtos, tendo como fonte o CONTRADE HS 96 


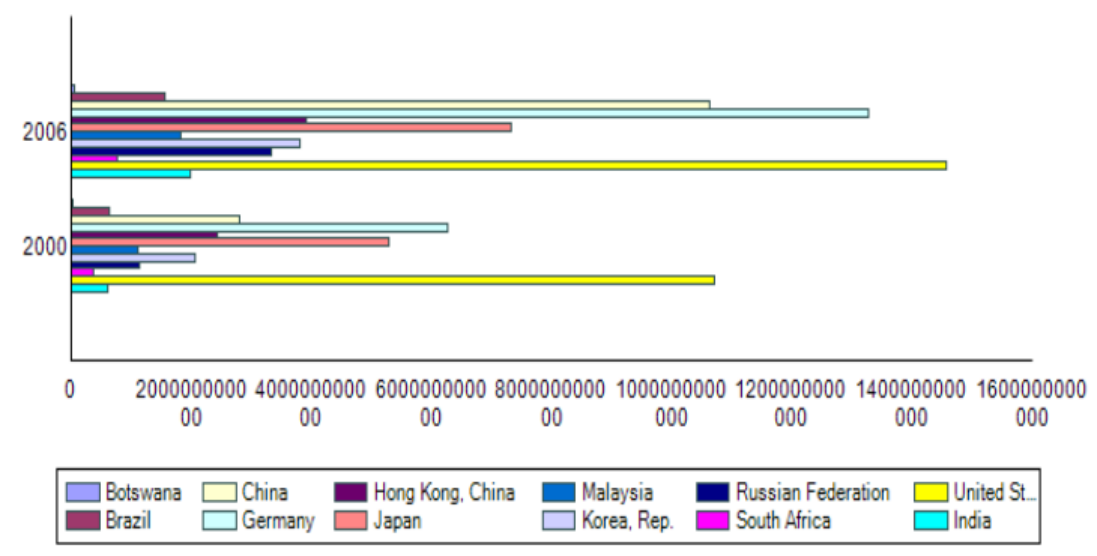

Figura 1.7: Exportações de bens e serviços. Fonte: World Bank (WDI).

com 4 dígitos, e associa esses índices de competitividade da pauta ao desempenho econômico na década de 2000. Posteriormente, o ensaio se utiliza desses índices de qualidade da pauta importadora e exportadora para discutir algumas teorias de crescimento e comércio externo.

O segundo ensaio concentra-se em um modelo em que a competitividade externa é a variável fundamental na determinação do PIB: o Modelo Keynesiano de Crescimento sob Restrição Externa. Além de ressaltar seu aspecto de modelo de restrição de demanda, enfatiza-se suas características estruturalistas, tornando-o um modelo que abrange diversos aspectos de oferta. A partir dele faz-se um estudo empírico para 137 países, com base nos dados do WDI (World Bank) para a década de 2000.

O último ensaio trata da economia brasileira, demonstrando, através de um modelo Kaldoriano, como um choque positivo do setor externo pode criar um ciclo virtuoso de crescimento. Argumenta-se que isso ocorreu para a economia brasileira na década de 2000. A partir desta discussão estrutural para um período de tempo reduzido, o ensaio discute como o período pode ter afetado a trajetória de longo prazo, levantando questões sobre a qualidade do crescimento brasileiro no período.

Note-se que todos os experimentos empíricos são datados, ou seja, referem-se à década de 2000 antes da crise do final da década. Nas Considerações Finais comentar-se-á as contribuições originais da tese no esclarecimento da relação entre competitividade externa e desempenho econômico. 


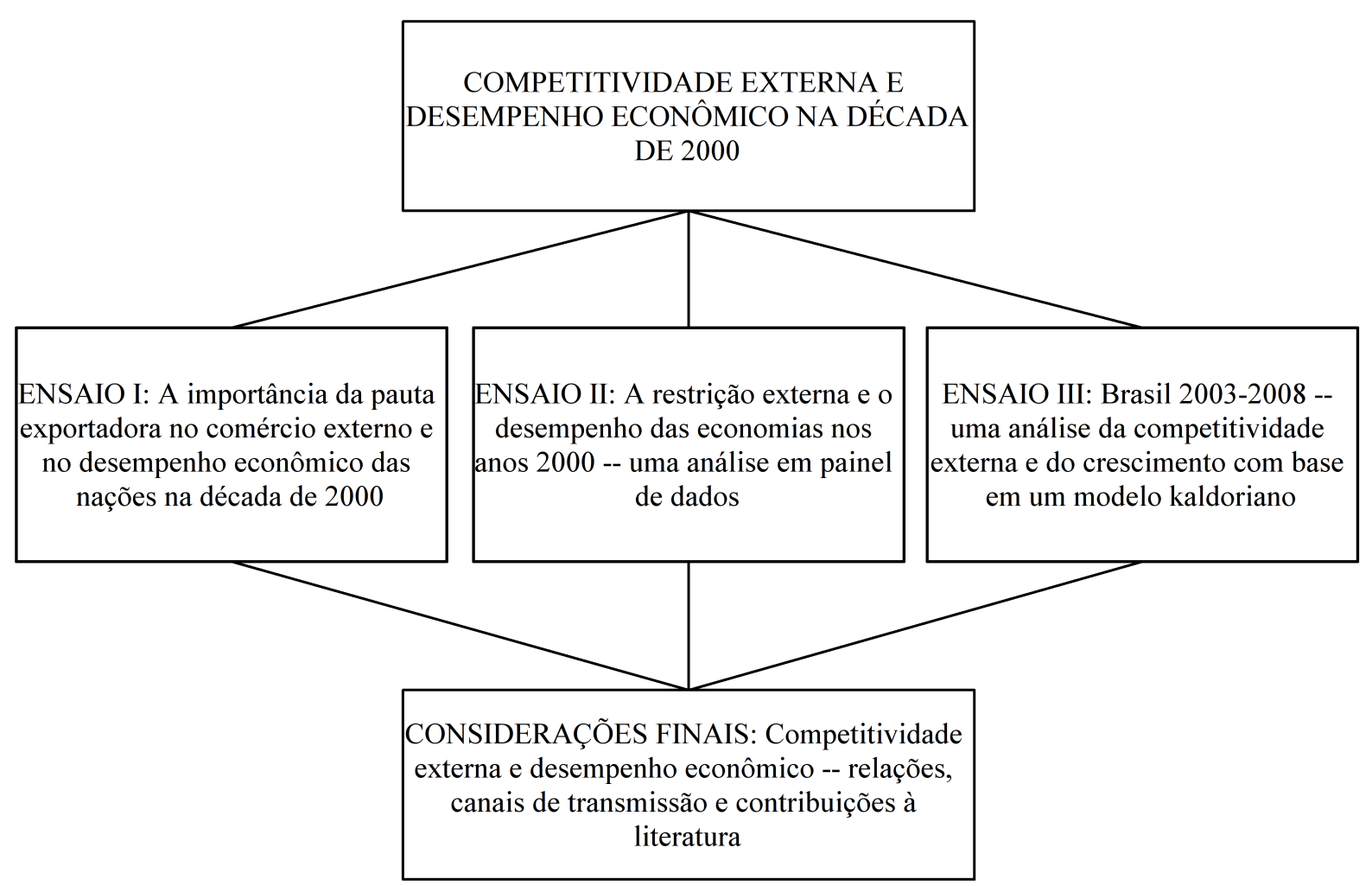




\section{Ensaio I: A importância da pauta do comércio externo no desempenho econômico das nações na década de 2000}

\subsection{Introdução}

O que um país produz, importa e exporta é importante na determinação do seu nível de renda ou do seu crescimento econômico? Ao investigar a resposta a essa questão, busca-se um melhor entendimento da rede de conexões que interligam o padrão de especialização da estrutura produtiva, competitividade externa e a determinação do nível de renda e do crescimento econômico.

Em uma visão mainstream mais fundamentalista, a adoção de uma função de produção agregada tipo Solow, associada a alguma versão do modelo de vantagens comparativas de Heckscher-Ohlin, confere um papel bastante passivo às transformações na estrutura produtiva como promotoras de crescimento econômico. Nessa visão, a dotação de capital físico e humano, trabalho, recursos naturais aliados à qualidade generalizada de suas instituições determinam os custos relativos da economia. Dessa forma, o padrão de especialização apenas reflete essa estrutura de custos relativos. O comércio exterior, por sua vez, deve apenas externalizar essa estrutura de custos, ou seja, o país exporta bens que tem vantagens comparativas, ou custos relativos baixos, e importa bens que tem custos relativos altos ou, em outras palavras, não tem vantagens comparativas. A estrutura de custos é determinada pela dotação de fatores e, portanto, não existiria nenhuma vantagem em produzir algum produto específico que não estivesse em consonância com a estrutura de custos. Nessa visão, tentativas de alterar a estrutura produtiva, gerando incentivos a conquistar mercados internos e externos, que não aqueles que modificam a estrutura de custos, teriam como única consequência a distorção alocativa e o uso ineficiente de recursos públicos. 
Entretanto, o retrato da década de 2000, que foi feito mais detalhadamente na introdução e que não é diferente dos grandes períodos na história econômica, é exatamente oposto. Ou seja, países como China e Índia, por exemplo, controlam o rumo da sua produção, gerando incentivos macro e micro para se especializarem em determinados tipos de bens. Isso sugere algo bastante simples: especializar-se em determinados bens pode ser melhor que se especializar em outros. Para resolver essa controvérsia, economistas de diferentes vertentes teóricas desenvolveram modelos que explicam por que seria melhor especializar-se em determinados bens e que características teriam esses bens.

Este ensaio tem como objetivo investigar as conexões empíricas entre a competitividade externa, tal como refletida na pauta exportadora e importadora, e a determinação do nível de renda e do crescimento econômico para a década de $2000,{ }^{1}$ relacionando os resultados empíricos com os modelos teóricos que investigam essa conexão.

Para isso, a primeira contribuição do artigo para a literatura será calcular, para a década de $2000,{ }^{2}$ um índice que permita medir o nível de renda média ponderado associado a determinada pauta exportadora e importadora, ou, em outras palavras, um índice de qualidade da pauta exportadora e outro índice de qualidade da pauta importadora. O calculo da renda média ponderada associada à pauta exportadora foi baseada no estudo de Hausmann, Hwang e Rodrik (2005), que calcularam esse índice para o período de 1992-2003. A contribuição do artigo é não apenas verificar a evolução do índice nesta década, mas também estendê-lo para a pauta importadora, uma vez que se acredita que a estrutura produtiva e o desempenho econômico possam ser de alguma forma afetados também pela qualidade das importações. Em dois dos modelos teóricos que trataremos neste ensaio (Modelo de Inovações Industriais Intencionais e Modelo de Crescimento sob Restrição Externa), a importação tem um papel primordial no desempenho econômico, seja através de comercialização de tecnologia, seja através da imposição de uma restrição de demanda.

Com base nesses índices, serão calculadas algumas estatísticas descritivas e serão feitos alguns testes econométricos visando refletir com mais clareza o papel da pauta exportadora e importadora no desempenho econômico, tendo em vista as questões colocadas pelas diferentes vertentes da teoria econômica sobre esse assunto, sendo essa uma segunda contribuição do ensaio. Desde já importa ressaltar que a construção dos índices de qualidade da pauta expor-

\footnotetext{
${ }^{1}$ Período para o qual existem razões para se acreditar que o posicionamento no mercado internacional foi fundamental para o desempenho desigual entre as economias A introdução faz uma resenha da década de 2000 e mostra com mais clareza como o posicionamento no mercado internacional foi importante para determinar o desempenho relativo das economias.

${ }^{2}$ Define-se década de 2000 como os anos 2000 a 2008. O ano de 2009 não fará parte da análise por duas razões: alguns países ainda não disponibilizaram os dados para esse ano e, a crise financeira do final de 2008 e 2009 pode afetar os resultados, adicionando um outro elemento de análise que não se pretende fazer neste estudo.
} 
tadora e importadora não está baseado em nenhuma teoria específica, é apenas um cálculo numérico. O resultado desse índice será utilizado para discutir as diversas teorias sobre desempenho econômico em economias abertas. Em outras palavras, as questões colocadas pela teoria guiarão os testes empíricos feitos com base nos índices, assim como suas interpretações. Dessa maneira, pode-se afirmar que esta é a terceira contribuição à literatura deste ensaio: utilizar os índices de qualidade da pauta exportadora e importadora para discutir as questões colocadas pela literatura teórica de crescimento ou o nível de renda em economias abertas.

Para atingir esse objetivo, o ensaio conta com cinco seções, além desta Introdução. A seção 2.2 faz uma revisão pontual dos modelos teóricos que tratam dessas co-influências entre pauta de comércio exterior e desempenho econômico. Ressalte-se, desde já, que a ideia não é um aprofundamento nesses modelos, o que seria difícil dado seu escopo e desnecessário do ponto de vista do argumento deste ensaio, mas sim sintetizar brevemente o argumento central de cada literatura. A seção 2.3 apresenta a metodologia de cálculo dos índices e dos testes empíricos, assim como a base de dados utilizada. A seção 2.4 apresenta resultados do trabalho empírico. A seção 2.5 discute e interpreta os resultados empíricos à luz do que foi apresentado na seção 2.2, ou seja, discute em que medida os resultados empíricos validam, corroboram, negam, ou simplesmente não acrescentam nada às teorias que foram apresentadas. Por fim, as considerações finais tecem alguns comentários e procuram conectar o que foi apresentado neste ensaio com as extensões que serão desenvolvidas nos próximos ensaios desta tese.

\subsection{Síntese dos modelos que estabelecem relações entre pauta de comércio externo e desempenho econômico}

Nesta seção far-se-á uma breve síntese de modelos que tratam da relação entre comércio externo e desempenho econômico. Segundo Frankel e Romer (1996), existem pelo menos quatro principais canais de transmissão entre comércio e renda. Um primeiro canal seria o ganho decorrente das vantagens comparativas. Um segundo canal seria a exploração dos retornos crescentes de escala. Outro canal poderia ocorrer através do desempenho do processo político via inibição do lobbying ou rent-seeking actions. Num quarto canal, o comércio pode afetar as tecnologias adotadas pelas firmas nacionais. O terceiro canal mencionado não será tratado neste ensaio, já que os dados empíricos que apresentaremos pouco esclarecem esse canal. Entretanto, este trabalho trabalhará com um escopo bem mais amplo do que este sugerido por Frankel e Romer (1996), incluindo análises que não estão enquadradas na teoria neoclássica e, portanto, o trabalho de síntese será fundamental. Não se trata de expressar todas as facetas e formalizações dos modelos, nem todos os seus desdobramentos e autores. 
A ideia central é apresentar apenas o suficiente para se entender qual a relação que o modelo estabelece entre comércio externo e desempenho econômico, quais as variáveis envolvidas nessa relação. Nessa passagem pelas teorias, poder-se-á observar que algumas se complementam, outras se enfrentam, e algumas não estabelecem nenhuma relação direta com as demais. Entretanto, apresentá-las será importante para sugerir os testes empíricos subsequentes.

Uma vez que a teoria econômica possibilitou diversos canais de transmissão entre o que se produz, se importa ou se exporta e o desempenho econômico, a literatura empírica acompanhou essa investigação com os dados disponíveis. Da mesma forma, apenas alguns exemplos dessa literatura serão expostos, principalmente os que contribuírem para a discussão que será feita com base no experimento empírico realizado neste ensaio.

Assim, segue-se uma síntese analítica dos principais modelos que estabelecem relação entre comércio externo e desempenho econômico.

\section{Vantagens Comparativas}

Este modelo estuda os impactos do comércio internacional integrando o modelo de comércio internacional Hecksher-Ohlin e um modelo de crescimento ótimo do tipo Solow. O modelo mostra que as vantagens comparativas são influenciadas pela interação entre os recursos da nação (a abundância relativa dos fatores de produção) e a tecnologia da produção (que influencia a intensidade relativa com a qual fatores diferentes de produção são usados na produção de bens diferentes). Dessa forma, os ganhos de comércio advêm das vantagens comparativas que emergem das diferenças de dotação de fatores entre países.

Na versão desse modelo apresentada por Ferreira e Trejos (2001) existem três bens: $A$ e $B$ são bens intermediários e $Y$ é o bem final. Os bens $A$ e $B$ são produzidos com tecnologias de retornos constantes e podem ser expressos pelas seguintes funções Cobb-Douglas:

$$
\begin{aligned}
& A=K_{A}^{\alpha_{A}} L_{A}^{1-\alpha_{A}} \\
& B=K_{B}^{\alpha_{B}} L_{B}^{1-\alpha_{B}} .
\end{aligned}
$$

Assume-se $\alpha_{A}<\alpha_{B}$ indicando-se que o bem $A$ é intensivo em trabalho e o bem $B$ intensivo em capital. Já o produto final $Y$ pode ser escrito como uma função de $a$ e $b$ efetivamente utilizados na produção (denomina-se $a$ e $b$ porque podem ser diferentes de $A$ e $B$ devido ao comércio internacional).

$$
Y=a^{\gamma} b^{1-\gamma}
$$


Supõe-se que exista um mercado internacional perfeitamente competitivo para $A$ e $B$, enquanto não há mobilidade de $K$ ou $L$. Em seguida, maximiza-se $Y=a^{\gamma} b^{1-\gamma}$ considerando a lei de movimento do capital, a condição de market-clearing para ambos os mercados, a condição de equilíbrio em conta corrente, com todos os mercados em concorrência perfeita, encontrandose assim $a^{*}$ e $b^{*}$ que maximizem os lucros e as utilidades dos consumidores. Duas condições de otimização devem ser ressaltadas:

Se, ao preço internacional $p$, tivermos $a^{*}>A$, o país exporta $A$; se, por outro lado, ao preço $p$, tivermos $b^{*}>B$, o país exporta $B$. Ou seja, preços locais dos tradables satisfazem a lei do preço único.

Nessa situação, em uma economia aberta com diferentes dotações de fatores, emergem cinco situações:

$$
F(K, L)= \begin{cases}\Omega_{1} K^{\alpha_{a}} L^{1-\alpha_{a}} & \text { se } K / L<s_{1} ; \\ \Omega_{2} K+\Omega_{3} L & \text { se } K / L \in\left[s_{1}, x_{1}\right] \\ \Omega_{4} K^{\bar{\alpha}} L^{1-\bar{\alpha}} & \text { se } K / L \in\left[x_{1}, x_{2}\right] \\ \Omega_{5} K+\Omega_{6} L & \text { se } K / L \in\left[x_{2}, s_{2}\right] \\ \Omega_{7} K^{\alpha_{b}} L^{1-\alpha_{b}} & \text { se } K / L>s_{2} .\end{cases}
$$

No caso 1 , em que $k<s_{1}$, a economia é tão escassa em capital que se especializará no bem intensivo em trabalho $(A)$ a qualquer preço relativo. No caso 2 , em que $k \in\left(s_{1}, x_{1}\right)$, será interessante para a economia exportar alguma quantidade de $A$ e importar alguma quantidade de $B$. O preço interno independe de $k$ e é determinado pelo preço internacional $p$. No caso 3 , em que $k \in\left(x_{1}, x_{2}\right)$, o preço local com autarquia é tão similar ao preço internacional que o ótimo para economia é não comercializar. Sem comércio, o preço no mercado interno é dependente de $k$, como em um modelo de Solow. No caso 4 , em que $k \in\left(x_{2}, s_{2}\right)$, será interessante para a economia exportar alguma quantidade de $B$ e importar alguma quantidade de $A$. É a situação oposta ao caso 2 . No caso 5 , ou seja, no caso em que $k>s_{2}$, a economia é abundante em capital e especializar-se-á no bem intensivo em capital, $B$, a qualquer preço relativo.

Ou seja, apenas na área $\left(x_{1}, x_{2}\right)$, em que as economias tem estruturas produtivas tão próximas que não vale a pena comercializar, o crescimento é dado por um modelo de crescimento de economia fechada. Em uma outra área, entre $\left(s_{1}, x_{1}\right)$ e $\left(x_{2}, s_{2}\right)$, a maximização de lucro das empresas se dá importando uma quantidade positiva de $A$ ou $B$; qualquer coisa que impeça esse comércio leva a um produto menor. Nas áreas $k<s_{1}$ ou $k>s_{2}$, as vantagens comparativas são tão fortes que nenhum preço impedirá o país de se especializar e de se beneficiar do comércio internacional. Assim, é apenas no caso $\left(x_{1}, x_{2}\right)$ que o comércio não aumenta a produtividade 
total de fatores; em todos os outros casos isso ocorre, pois existe um melhor correspondência entre a demanda interna e a oferta em um mercado aberto e isso traz ganhos de produto neste modelo.

Baseado neste instrumental, Ferreira e Trejos (2001) fazem um estudo de tarifas ótimas, e Ferreira e Rossi (2003) fazem um estudo sobre economias abertura econômica e pobreza, entre outros estudos dessa natureza.

Em relação ao modelo apresentado, do ponto de vista da análise desenvolvida neste trabalho, é interessante ressaltar alguns aspectos:

1. Estrutura produtiva, nessa linha de modelos, é um conceito restrito à intensidade no uso dos fatores de produção. Por essa razão, o estudo da evolução da estrutura produtiva confunde-se com a análise de acumulação de fatores de produção, já que a intensidade relativa de fatores define a estrutura produtiva e a posição no comércio internacional. Não existe, neste modelo básico, diferenciação de produtos na capacidade de gerar progresso tecnológico, spillovers de oferta, ou spillovers de demanda, aspectos que serão abordados nas teorias apresentadas a seguir.

2. Fundamental aos resultados é a hipótese de concorrência perfeita nos mercados. $\mathrm{O}$ abandono dessa hipótese, tal como feita por Dixit e Stiglitz (1977) e Krugman (KRUGMAN, 1980; KRUGMAN, 1989), já introduz novas considerações relevantes.

3. O padrão de especialização é completamente passivo à dotação de fatores e não tem efeitos diretos no crescimento econômico. Ou seja, em qualquer estágio de $k$, o acesso ao mercado internacional permite a obtenção de um equilíbrio de máximo produto, pois é a restrição do acesso ao mercado que pode levar a um produto menor e não o fato haver alguma especialização. Não existe qualquer elemento no modelo que sugira que a especialização em $A$ ou $B$ possa levar a uma trajetória do produto melhor ou pior.

Concluindo, em um modelo onde os ganhos de comércio advêm das vantagens comparativas, ou seja, da diferença de dotação entre países, ao comercializar os países superam a escassez relativa de dotações ou de tecnologia. Ao fazer isso, a produtividade e o nível de produto aumentam. Contanto que a economia possa ter livre acesso ao mercado internacional, não existe padrão de especialização que seja melhor ou pior para o desenvolvimento econômico. Esse resultado está correlacionado com a definição de estrutura produtiva, com a hipótese de concorrência perfeita e com a inexistência de spillovers de tecnologia e de demanda. 


\section{Retornos Crescentes de Escala}

Este modelo, desenvolvido por Dixit e Stiglitz (1977), Krugman (KRUGMAN, 1980; KRUGMAN, 1989) e Grossman e Helpman (GROSSMAN; HELPMAN, 1989; GROSSMAN; HELPMAN, 1990), introduz um mercado não concorrencial, ou seja, um modelo de competição monopolística. Nesse caso, existem dois países que podem produzir ou consumir quaisquer variedades de produtos que entrem simetricamente no consumo.

Neste modelo, o aumento da participação no comércio exterior vem não da redução de preços (como se esperaria de um modelo de vantagens comparativas), mas do aumento de variedades de produtos que ocorre conforme o produto de um país aumenta. Tomemos uma economia que só produz através de $L$ (trabalho), para tirar qualquer ganho advindo de vantagens comparativas na dotação de fatores e deixar que todo o ganho venha da escala. Os consumidores maximizam a seguinte função utilidade:

$$
U=\left(\theta^{-1} \sum c i^{\theta}\right)^{1 / \theta}
$$

Para uma firma produzir uma variedade de um bem, ela tem um custo fixo, fruto da competição monopolística:

$$
l_{i}=\alpha+\beta x_{i}
$$

Dado que $\sum l_{i}=L$ e que cada firma que produz depara-se com uma elasticidade de demanda de $\theta / \frac{1}{1-\theta}$. Dada essa elasticidade de demanda, cada firma fixa um mark-up

$$
p / w=\beta / \theta
$$

Assim, a condição de lucro zero determina que o produto e o emprego por produto sejam

$$
x(p / w-B)=\alpha>x=\frac{\alpha_{\theta}}{\beta(1-\theta)}
$$

$\mathrm{e}$

$$
1=\frac{\alpha}{1-\theta}
$$

Logo, o número de variedades produzidas em um país é proporcional a sua força de trabalho:

$$
n=L(1-\theta) / \alpha \text {. }
$$

Consideremos agora dois países com forças de trabalho $L$ e $L^{*}$, que agora representam uma só economia com tamanho $L+L^{*}$. O comércio vai resultar de que os consumidores das 
economias queiram diversificar suas variedades. Assim, eles podem consumir uma parcela $n /\left(n+n^{*}\right)=L /\left(L+L^{*}\right)$ de bens nacionais e $n^{*} /\left(n+n^{*}\right)=L^{*} /\left(L+L^{*}\right)$ de bens estrangeiros. $\mathrm{O}$ produto agora será

$$
y=w L / p=L \frac{\theta}{p} .
$$

Vamos agora supor que essas economias estejam crescendo desigualmente. A economia que cresce mais rápido não diminui os preços relativos, que continuam equalizados, mas aumenta a variedade de bens produzidos e exportados.

Se não considerássemos que as variedades de produtos estão aumentando, chegaríamos a conclusão de que

$$
\frac{Y}{Y^{*}}=\frac{\epsilon}{\pi}
$$

Ou seja, a razão entre produtos é igual à razão entre as elasticidades. Entretanto, este resultado só emerge no agregado, pois o país que esta crescendo mais está aumentando a diversificação de produtos e a oferta está se deslocando. Portanto, segundo a teoria, deve-se desconsiderar a possibilidade de que elasticidades determinam diferenciais de produto, mostrando através de um modelo de competição monopolística que o sinal é inverso.

Vários trabalhos foram feitos em um arcabouço de competição monopolista, como Romer (1990), que constrói um novo modelo de tecnologia endógena, e Rodrigues (2006), que analisa o processo de substituição brasileiro, entre outros.

Note-se que esse modelo, tratado desta forma, contrasta diretamente com o Modelo Keynesiano de Restrição Externa que será apresentado mais adiante e que defende o sinal oposto da teoria, ou seja, que o diferencial de elasticidades causa diferenciais de produtos. Na verdade, Krugman (1989) utiliza o modelo de competição monopolística para inverter a casualidade do Modelo Keynesiano de Restrição Externa. ${ }^{3}$, ou seja, Krugman argumenta que não é a elasticidade que determina produto e sim o contrário por meio do que ele denominou "regra de $45^{\circ}$ ".

\footnotetext{
${ }^{3}$ Uma vertente de modelos que ganhou ênfase na literatura foram os modelos de export-led-growth Esses modelos se dividem em dois arcabouços teóricos: pelo lado da oferta e pelo lado da demanda. Pelo lado da oferta os autores usam os argumentos de eficiência (vantagens comparativas) e tamanho de mercado (retornos de escala) para provar que exportações causam crescimento por esses meios. Maiores esclarecimentos em Faleiros (2008). Não entraremos mais profundamente nessa literatura porque é uma literatura mais empírica que testa a relação entre exportações e produto, baseado nos modelos teóricos que já colocamos nessa resenha.
} 


\section{Crescimento Endógeno - Inovações Industriais Intencionais}

Grossman e Helpman (1991) ${ }^{4}$ deram uma contribuição importante para a discussão aqui desenvolvida, baseados nos modelos de crescimento endógeno de inovações industriais intencionais. Nessa linha de modelos, a economia produz o produto $Y$ baseado em insumos intermediários por meio de uma função de produção homogênea. A partir daí, podem-se distinguir duas situações. Em uma situação, os insumos são horizontalmente diferenciados. Neste caso, o produto é proporcional ao trabalho empregado na manufatura dos insumos e o fator de proporcionalidade é uma função crescente do número disponível de insumos ( $n$ ) que se expande como resultado do investimento em Pesquisa e Desenvolvimento (P\&D). O trabalho pode ser empregado ou na manufatura ou em P\&D. Assim, a PTF (Produtividade Total de Fatores) pode ser em grande parte explicada por uma medida cumulativa de P\&D. Na outra situação, os insumos são verticalmente diferenciados, ou seja, variam em qualidade, de forma que a qualidade e a produtividade do insumo dependem do número de vezes em que foi processado. Neste caso, o investimento em P\&D aumenta a qualidade dos insumos e aumenta a PTF.

Com base nessa teoria, considera-se que estes insumos são comercializáveis. Neste caso, é possível que os investimentos em P\&D de um país transfiram-se para outro por intermédio do comércio internacional. Esse é o caso considerado por Coe e Helpman (1995), que estudaram em que medida a PTF depende dos investimentos em P\&D próprios e dos investimentos em $\mathrm{P} \& \mathrm{D}$ dos demais países com que comercializa. Os autores estimaram o efeito para 21 países da OCDE entre 1971-90 e concluíram que o investimento em P\&D externo tem efeitos positivos na produtividade doméstica, sendo esses efeitos maiores em economias abertas. Já o experimento realizado por Keller (1998) enfatiza os efeitos P\&D externo na produtividade doméstica, mas confronta o fato de isso ocorrer por meio dos parceiros de comércio e, assim, destacam o papel da difusão não comercializável. Já o estudo empírico realizado por Ram e Keller (2007) enfatizam o papel da transferência tecnológica internacional, especialmente nas indústrias de alta tecnologia, e consideram as importações como o principal canal desta transferência. A discussão deste canal de transmissão é particularmente relevante para este estudo, uma vez que discute diretamente a influência da pauta importadora na promoção do desenvolvimento. $\mathrm{Ou}$ seja, a existência deste canal é uma das justificativas para a inclusão da qualidade da pauta importadora como promotora do desempenho das nações.

\footnotetext{
${ }^{4} \mathrm{O}$ trabalho de Grossman e Helpman (1991) na linha de modelos de crescimento endógeno, como Romer (1990), sugere um modelo que endogeneiza o progresso tecnológico mediante gastos em P\&D.
} 


\section{Modelos de Falhas de Mercado}

Os modelos de falha de mercado apontam diversas falhas de mercado que podem ocorrer no Modelo I e no Modelo II e que afastam a produção do ótimo apontado por esses modelos. Além do mais, alguns destes modelos têm uma característica cumulativa, ou seja, uma vez que uma economia se afasta de sua produção ótima é cada vez mais difícil voltar, pois o caminho é path-dependent. Essas falhas podem ocorrer no mercado de trabalho, de produto e na estrutura institucional. Vejamos alguns exemplos:

\section{Modelos DE AJUSTAMENTO SETORIAL}

Matsuyama (1992) constrói um modelo de dois setores, onde, ao nascer, o trabalhador tem que escolher em que setor vai trabalhar e não pode voltar atrás. O trabalhador tem uma probabilidade $p$ de morrer e novos trabalhadores entrarão no mercado, decidindo em que setor trabalharão. A mudança entre setores ocorre, portanto, na velocidade de novos entrantes no mercado, ou seja, todo o ajustamento setorial é demográfico.

Dessa forma, os trabalhadores não podem reagir imediatamente a variações de preços entre setores e a produção pode ficar dentro da fronteira de possibilidades de produção por um período.

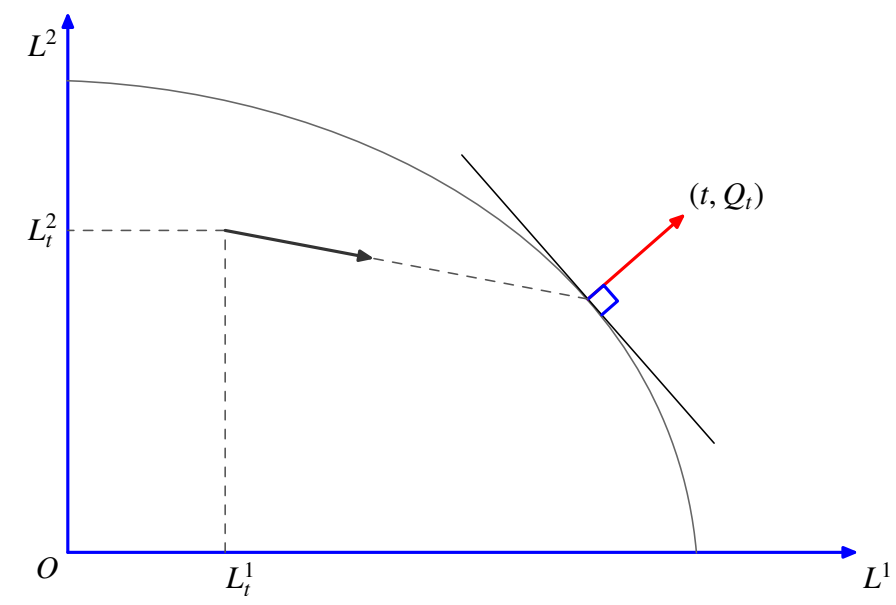

Assim, o modelo cria um mecanismo por meio do qual uma economia pode ficar, durante um tempo, produzindo uma quantidade de produtos não ótima. Ou seja, pode continuar no setor 1 mesmo que os preços relativos favoreçam uma migração para o outro setor, pois a mão de obra ainda não teve tempo para se ajustar. Entretanto, vale notar que este modelo não é cumulativo. Uma vez que a transformação demográfica ocorre a economia volta a produzir o ótimo nos dois setores. 


\section{LEARNING-BY-DOING SPILLOVERS}

Uma forma de endogeneizar o crescimento é retirar os retornos decrescentes de fatores acumuláveis. Assim, segundo Barro e Sala-i-Martin (2004), Romer (1986) usou a ideia de Arrow (1962) para eliminar os retornos decrescentes assumindo que a criação de conhecimento $(A)$ era um subproduto do investimento. Este efeito positivo da experiência na produtividade é chamado de learning-by-doing.

A outra hipótese é de que o conhecimento produzido torna-se um bem público. Assim, assumi-se que todo conhecimento é gerado como subproduto do investimento e imediatamente se torna um bem comum. Essa é a hipótese de learning-by-doing spillovers, ou seja, de que o investimento de uma firma cria uma externalidade que é o conhecimento proporcional ao estoque de capital da economia. Formalmente,

$$
Y_{i}=F\left(K_{i}, A_{i} L_{i}\right)
$$

Como $A_{i}$ é bem público gerado pelo investimento e, portanto, proporcional ao estoque de capital da economia, temos:

$$
Y_{i}=F\left(K_{i}, K^{*} L_{i}\right)
$$

A extensão em que esses spillovers acontecem são cruciais para as implicações do modelo de learning-by-doing spillovers. No caso deste estudo interessa considerar o caso em que esses spillovers são setoriais. Neste caso, se uma economia começa produzindo determinados produtos, ela gerará conhecimento naqueles produtos, impedindo que os retornos decrescentes ocorram naqueles setores.

Dessa forma, as novas firmas não têm incentivos para migrar para novos setores não contemplados com esses spillovers e, assim, a economia tende a produzir sempre os mesmos produtos.

\section{COST DISCOVERY}

Outra teoria que apresenta um nítido canal entre estrutura da pauta exportadora, ou estrutura produtiva e crescimento é o canal de Cost Discovery - tal como apresentado por Hausmann, Hwang e Rodrik (2005). Em seus trabalhos, os autores argumentam que a produção de um produto depende de uma variedade de insumos específicos, alguns privados, outros públicos. Para esses insumos serem aplicados em determinada atividade, torna-se necessário que sejam mais produtivos nesta atividade que nas demais. No entanto, estes insumos são feitos para as atividades já existentes e, portanto, não são desenhados para as potenciais novas atividades. Para entrar 
em uma atividade não existente há um cost discovery não internalizado. Dessa forma, o rumo do desenvolvimento pode depender das atividades já existentes na economia. Como a diferença de capacidade existente requerida é muito grande entre commodities e produtos intensivos em tecnologia, por exemplo, um país que produz commodities tende a não gerar a estrutura necessária para a produção de produtos de tecnologia. Assim, o rumo do desenvolvimento ganha uma dependência temporal. Ao introduzir esse novo canal, o crescimento econômico depende não somente dos fundamentos convencionais, mas também do número de investimentos estimulados no setor moderno da economia. Nesse sentido, políticas de comércio exterior potencialmente teriam um impacto positivo sobre produto ao induzir investimentos no setor moderno.

\section{EFEITOS DE REDE E ESPECIALIZAÇÃo GEOGRÁFICA}

Hidalgo et al. (2007) e Hausmann e Klinger (2006) argumentam que apenas uma variável (sofisticação da pauta) pode não englobar todos os aspectos da estrutura dos produtos. Assim, propõem uma network geographic view para descrever a interdependência dos produtos e dessa forma clarificar algumas questões do desenvolvimento. O espaço de produtos não é homogêneo e pode haver espaços mais densos onde as inovações ocorrem com mais facilidade e outros em que é preciso um grande salto. Eles mostram que países tendem a diversificar produzindo produtos que estão próximos de produtos que eles já produzem. Além disso, essa rede tem implicações geográficas; por exemplo, na Euroasia o comércio leste-oeste possibilitou a ocorrência de inovações que se espalharam entre os continentes. Já a América e a África deveriam explorar o trecho norte-sul que é menos denso. Enfim, esse instrumental de redes geográficas e espaço de produtos constitui uma nova visão para analisar crescimento econômico baseado na especialização produtiva.

\section{Modelo Keynesiano de Restrição Externa}

As análises mais convencionais, tipicamente de extração neoclássica, do processo de crescimento econômico focalizam exclusivamente os determinantes da expansão do produto no lado da capacidade de ofertar bens e serviços, ou seja, a acumulação de estoques de capital físico e humano, tecnologia etc. Por sua vez, Thirlwall (1979), assim como outros autores inspirados em Keynes, propõe considerar-se que, em geral, antes de exaurir-se tal potencial de geração do produto de um país, restrições na demanda agregada por bens e serviços apresentam-se como fator de limitação mais significativo. Além disso, no contexto de economias abertas, Thirlwall assinala que as restrições quanto à disponibilidade de divisas tendem a apresentar-se como o principal obstáculo a níveis mais elevados de demanda agregada. 
De acordo com Lei de Thirlwall, a taxa de crescimento do país não poderá distanciar-se muito da seguinte conta: a taxa de crescimento do produto mundial, multiplicada pela elasticidaderenda das exportações e dividida pela elasticidade-renda das importações, ${ }^{5}$

$$
y_{b p}=\frac{\epsilon z}{\pi},
$$

em que $x=\epsilon z$ é a taxa de crescimento das exportações, ou a elasticidade-renda das exportações vezes a renda externa, $\pi$ é a elasticidade-renda da demanda por importações e $y_{b p}$ representa a taxa de crescimento do produto consistente com a satisfação da restrição relativa ao estabelecimento do equilíbrio externo.

O ingresso líquido de capitais externos provê a possibilidade de desvios em relação a essa conta, porém dentro de certos limites. Evidentemente, a restrição comercial determinada por elasticidades-renda pode vir a ser alterada por mudanças nos patamares da taxa real de câmbio, mas a economia teria de apresentar processos de desvalorização ou valorização cambial real permanente. Logo, a competitividade estrutural do país, conforme refletida nas elasticidadesrenda de exportações e importações, acaba, através destas últimas, determinando seu potencial de crescimento.

Desde logo, é fundamental esclarecer que a abordagem do crescimento sob restrição externa à Thirlwall, não obstante esteja assentada no pressuposto de que restrições na demanda agregada apresentam-se como fator de limitação mais significativo ao crescimento econômico no longo prazo, não ignora a relevância de fatores associados à oferta agregada. Afinal, as elasticidades-renda são o reflexo de uma variedade de fatores em nível de oferta que condicionam a competitividade estrutural da economia. Neste sentido, a análise de restrição externa se aproxima muito da análise estruturalista da CEPAL, como será ressaltado no próximo ensaio.

O trabalho de McCombie (McCOMBIE, 1989; McCOMBIE, 1997) propôs um teste empírico mais consistente da Lei de Thirlwall, baseado no instrumental de séries de tempo. A partir de então diversos autores como Hussain (1999), Alonso e Garcia Matrín (1998), Bértola, Higachi e Porcile (2002), Moreno-Brid (MORENO-BRID, 1998; MORENO-BRID, 1999; MORENO-BRID, 2003), Lima e Carvalho (2009) entre outros, tiveram sucesso em provar, nos termos dessa literatura específica, que a restrição externa realmente era um limitante ao crescimento de um país ou grupos de países.

\footnotetext{
${ }^{5}$ A derivação desta formula pode ser vista no Ensaio II mais claramente, entretanto, é importante justificar que é uma mero ajuste de uma equação de equilíbrio em conta corrente $P d X=P f M E$ (Exportações são iguais a Importações na mesma moeda), em que variações de preços relativos não têm em papel relevante para obtenção do equilíbrio.
} 


\section{A visão Kaldoriana/Keynesiana/Chenery\& Syrquim}

A visão Kaldoriana foca na diferença entre os setores na promoção do desenvolvimento. Para Kaldor (1966), o processo de desenvolvimento econômico implicava a transferência de fatores do setor com setores decrescentes de escala para o setor com retornos crescentes, criando economias dinâmicas de escala. Na visão original de Kaldor, o setor de retornos crescentes era a indústria, mas a análise pode ser estendida para setores com retornos crescentes, industriais ou não, e setores com retornos decrescentes de escala. O importante, do ponto de vista desta análise, é que existem setores que promovem mais crescimento que outros e a transferência de recursos entre eles aumenta o produto e a produtividade.

Kaldor (1970) argumenta que a taxa de crescimento da produtividade depende, primordialmente, da taxa de crescimento da economia, da composição da demanda e do peso do setor de bens de capital na estrutura produtiva. Note-se que a estrutura da demanda passa a ter um papel importante no crescimento. Investimentos altos e um maior setor de bens de capital geram maior produtividade e desempenho mais competitivo. Duas razões para que isso ocorra é que o setor de bens de capital tem retornos crescentes e a inovação tecnológica está incorporada no setor de bens de capital.

Nessa mesma visão, o trabalho de Chenery, Robinson e Syrquin (1986) argumenta que o crescimento econômico pode ser visto como um aspecto da transformação produtiva que é necessária para atender transformações de demanda e para fazer um uso mais produtivo da tecnologia. Note-se que as transformações de demanda são um elemento dinâmico que induzem a mudança de estrutura. $\mathrm{O}$ outro ponto é o uso mais produtivo da tecnologia, ou seja, a economia cresce quando transfere capital e trabalho para setores com maior tecnologia. Os autores fazem um estudo empírico interessante sobre as fontes da transformação produtiva em diversos países e traçam caminhos típicos de desenvolvimento (expot-led growth, import substitution) e as composições setoriais das transformações estruturais.

Essa análise remete a uma questão presente na economia de crescimento KeynesianaKaldoriana que é a endogeneidade dos fatores de produção à demanda efetiva. A Lei de VerdoornKaldor (VERDOORN, 1980) relaciona crescimento do produto e taxa de crescimento da produtividade. Diversos trabalhos empíricos, entre eles o de León-Ledesma e Thirlwall (2002), foram elaborados para testar as relações de causalidade entre crescimento e produtividade, encontrando uma relação bilateral. Ou seja, o aumento do produto gera aumento da produtividade que gera aumento do produto, criando um ciclo virtuoso; portanto, a cumulatividade do processo torna-se um fator importante. 
Em outras palavras, integrando as correntes keynesianas e kaldorianas, a passagem para produtos melhores, seja porque estes têm maior elasticidade-renda e com isso melhorem as condições do equilíbrio externo, seja porque geram mais produtividade explorando melhor os retornos crescentes, pode gerar um multiplicador macroeconômico em que o processo passa a ser cumulativo.

Cornwall e Cornwall (1994) criam uma hierarquia de três setores: agricultura, industria e serviços, que poderia ser estendida a um número maior de setores. A elasticidade-renda da demanda cria uma hierarquia entre os três setores na geração de renda, ou seja, conforme a renda cresce, desenvolvem-se setores com uma maior elasticidade-renda, que geram uma maior produtividade. Enfim, o modelo proposto enfatiza o crescimento da demanda na transformação da estrutura e o impacto no desenvolvimento econômico. Se for ampliado o uso de três setores para uma cesta de produtos, esse mecanismo pode nos ajudar a entender por que alguns produtos podem ser melhores para desenvolvimento que outros.

Setterfield (1997) mostra que em uma economia de causação cumulativa o estudo das trajetórias históricas podem levar a resultados mais consistentes que a busca de um equilíbrio, o que é um pressuposto da análise Kaldoriana.

Em síntese, nessa visão em geral, não obstante as diferentes interpretações entre os autores, alguns setores são melhores que outros porque geram maiores economias de escala, promovem mais a tecnologia e a produtividade, gerando mais renda, que por sua vez induz transformações estruturais nesta direção, gerando um ciclo virtuoso.

\section{Neo-Schumperianos}

Segundo Martins (2008), modelos evolucionários neo-schumpeterianos focam a questão do progresso tecnológico ou a dinâmica do processo de evolução capitalista como elemento fundamental do processo. A estrutura produtiva tem influência na determinação dessa dinâmica e, portanto, influenciaria diretamente o processo de desenvolvimento. A definição de eficiência schumpeteriana considera o desenvolvimento tecnológico como o principal fator explicativo das diferenças intersetoriais de crescimento e como motor do crescimento econômico. Essa definição de eficiência schumpeteriana prescreve um padrão de especialização da pauta exportadora baseado na exportação de produtos para os quais se identifique um elevado grau de oportunidade, apropriabilidade e cumulatividade tecnológica. A ideia de oportunidade tecnológica diz respeito às possíveis rotas de desenvolvimento, associadas a um dado paradigma tecnológico. Um grau elevado de oportunidade tecnológica significa um campo mais amplo de possibilidades de introdução de inovações. Entretanto, a decisão de inovar está associada à lucratividade; as- 
sim quanto maiores os lucros de monopólios relacionados à inovação, maior a probabilidade de apropriação do lucro e maior o incentivo para inovar. Por outro lado, o padrão de mudança tecnológico não é exógeno aos padrões correntes de especialização produtiva e comercial, criando uma cumulatividade do processo.

Assim, para essa literatura, os bens exportados devem ter elevado grau de oportunidade para novas inovações, maior apropriação do lucro da inovação e maior aproveitamento das externalidades positivas do padrão de especialização vigente ou diminuição das externalidades negativas. De qualquer forma o padrão de especialização atual condiciona o futuro. A aplicação deste conceito de eficiência schumpeteriana ao comércio é ainda mais intrincado por ser difícil mensurar a oportunidade, cumulatividade e apropriabilidade dos produtos. Com base nessa dificuldade foi criada uma nova classificação de comércio internacional segundo o critério de conteúdo tecnológico (UNCTAD). Nessa literatura, destacam-se os trabalhos de Silverberg e Soete (1994), Fagerberg (2000), Dosi e Fabiani (1994), entre outros.

Na linha de investigação da qualidade dos bens produzidos em relação à produtividade e desenvolvimento de tecnologia foram feitos uma série de estudos empíricos. Lall (2000), em seu estudo para países desenvolvidos e em desenvolvimento entre 1985-1998, segmenta as exportações em cinco grupos: primários, manufaturados baseados em recursos naturais, manufaturados de baixa, média e alta tecnologia. O principal argumento é que produtos de baixa tecnologia tentem a crescer menos no comercio internacional; como a estrutura de exportação é pathdependence, a especialização em produtos de baixa tecnologia tem implicações negativas em crescimento econômico. Fagerberg (2000) estudou o impacto da especialização e mudanças estruturais no crescimento da produtividade da indústria para 39 países e 24 indústrias entre 1973 e 1990. A principal conclusão é que a transformação estrutural no período é importante, mas não porque as indústrias de alta tecnologia crescem proporcionalmente em termos de emprego em relação às indústrias tradicionais, mas porque alguns setores apresentaram um aumento muito maior da produtividade; nesse período, foi o caso da indústria eletroeletrônica: países onde essa indústria era mais significativa cresceram mais. Cimoli, Porcile e Rovira (2010) mostram uma correlação entre intensidade tecnológica das exportações e a participação das exportações no comércio mundial para países da Ásia e da América Latina entre 1961 e 2002. Nesta mesma linha, Cimoli (2005) argumenta que o estudo dos determinantes do crescimento de longo prazo requer analisar em que medida a transformação estrutural de cada país se direcionou para os setores que têm capacidade de promover o progresso técnico, acompanhar as tendências mais dinâmicas da demanda e gerar empregos de mais alta produtividade. Para isso, o autor mostra uma correlação entre o aumento da participação dos setores difusores de conhecimento e crescimento para 17 países entre 1970 e 2000. Dalum, Laursen e Verspagen (1996) também 
investigam a relação entre especialização e crescimento, utilizando uma base de dados de 11 setores industriais para os países da OCDE entre 1965 e 1988. Os autores calcularam um índice de Valor Adicionado das Exportações (algo próximo do que será feito neste trabalho, mas com uma desagregação muito menor) e regrediram este índice contra uma série de variáveis de emprego, investimento, tecnologia, pesquisa e desenvolvimento, patentes, catch-up e especialização. Os resultados indicam que a especialização realmente importou para o valor adicionado das exportações e, assim, para o crescimento desses 17 países.

\section{Neo-Estruturalistas}

A contribuição neo-estruturalista apresenta modelos nos quais um conjunto de países (norte) tem características diferentes de outro tipo de países (sul). A hipótese normalmente utilizada é que o sul tem uma estrutura de mercado competitiva, enquanto o norte tem uma estrutura não-concorrencial, o que se manifesta nos preços relativos das duas economias. A interação entre esses dois grupos de países no mercado internacional contribui para o entendimento da

Tabela 2.1: Modelos de crescimento em economias abertas.

\begin{tabular}{|c|c|c|c|}
\hline Modelo & Autores & Características Produtos & Efeito Comercio Internacional \\
\hline Vantagens comparativas & $\begin{array}{l}\text { Heckscher, Ohlin, } \\
\text { Solow e } \\
\text { Ferreira-Trejos }\end{array}$ & $\begin{array}{l}\text { Produtos se diferenciam pela } \\
\text { intensidade de } K \text { e } L \text {. }\end{array}$ & $\begin{array}{l}\text { Vantagem comparativa exógena define bem } \\
\text { produzido — máximo crescimento. }\end{array}$ \\
\hline $\begin{array}{l}\text { Concorrência } \\
\text { monopolística }\end{array}$ & $\begin{array}{l}\text { Krugman, Dixit e } \\
\text { Siglitz }\end{array}$ & $\begin{array}{l}\text { Diferentes variedades de } \\
\text { produtos no setor de retornos } \\
\text { crescentes. }\end{array}$ & $\begin{array}{l}\text { O processo de aumento. } Y \text { ocorre um aumento de } \\
K \text {, expanção número de variáveis e aumenta } \\
\text { participação comércio mundial. }\end{array}$ \\
\hline $\begin{array}{l}\text { Inovações industriais } \\
\text { intencionais }\end{array}$ & $\begin{array}{l}\text { Grossman e } \\
\text { Helpman }\end{array}$ & $\begin{array}{l}\text { Diferentes variedades ou } \\
\text { qualidades dos insumos } \\
\text { relacionados a P\&D. }\end{array}$ & $\begin{array}{l}\text { Transmissão de tecnologia através importação de } \\
\text { insumos. }\end{array}$ \\
\hline $\begin{array}{l}\text { Falhas de mercado: } \\
\text { ajustamento setorial }\end{array}$ & Matsuyana & $\begin{array}{l}\text { Quantidade de trabalho nos } \\
\text { setores depende apenas de } \\
\text { transformação demográfica. }\end{array}$ & $\begin{array}{l}\text { A transformação demografica é mais lenta que o } \\
\text { ajuste de preços e a economia pode ficar durante } \\
\text { um tempo produzindo quantidades não-ótimas } \\
\text { dos bens. }\end{array}$ \\
\hline $\begin{array}{l}\text { Falhas de mercado: } \\
\text { learning-by-doing }\end{array}$ & Arrow e Romer & Diferentes produtos e setores. & $\begin{array}{l}\text { Path-dependence no processo de mudança } \\
\text { estrutural com base no aprendizado. }\end{array}$ \\
\hline $\begin{array}{l}\text { Falhas de mercado: } \\
\text { cost-discovery }\end{array}$ & $\begin{array}{l}\text { Hausman, Hwang e } \\
\text { Rodrik }\end{array}$ & $\begin{array}{l}\text { Diferentes produtos e insumos } \\
\text { específicos. }\end{array}$ & $\begin{array}{l}\text { Externalidades públicas e privadas geram } \\
\text { path-dependence no processo de } \\
\text { desenvolvimento. }\end{array}$ \\
\hline $\begin{array}{l}\text { Falhas de mercado: } \\
\text { efeitos de rede e } \\
\text { especialização geográfica }\end{array}$ & $\begin{array}{l}\text { Hidalgo, Klinger e } \\
\text { Hausman }\end{array}$ & $\begin{array}{l}\text { Diferentes espaços de produtos } \\
\text { e rotas de comércio. }\end{array}$ & $\begin{array}{l}\text { Diferentes espaços de produtos levam a } \\
\text { determinadas especializações e é difícil mudar o } \\
\text { curso do desenvolvimento. }\end{array}$ \\
\hline $\begin{array}{l}\text { Crescimento restrição } \\
\text { externa }\end{array}$ & $\begin{array}{l}\text { Thirlwall- } \\
\text { McCombie }\end{array}$ & $\begin{array}{l}\text { Diferentes produtos com } \\
\text { elasticidades de demanda } \\
\text { diferentes. }\end{array}$ & $\begin{array}{l}\text { Restrições no balanço de pagamentos pode } \\
\text { limitar crescimento. }\end{array}$ \\
\hline Kaldoriana & Kaldor & $\begin{array}{l}\text { Diferentes produtos com } \\
\text { elasticidades de demanda } \\
\text { diferentes e retornos de escala } \\
\text { diferenciados. }\end{array}$ & $\begin{array}{l}\text { Desenvolvimento como transferência } \\
\text { inter-setorial. Importância composição demanda, } \\
\text { investimento. }\end{array}$ \\
\hline Neo-schumpeteriana & $\begin{array}{l}\text { Vespargen, Dosi e } \\
\text { Fabiani }\end{array}$ & $\begin{array}{l}\text { Produtos com diferentes } \\
\text { capacidades de gerar } \\
\text { cumulatividade tecnológica. }\end{array}$ & $\begin{array}{l}\text { Criação de rotas de desenvolvimento que } \\
\text { propiciem a inovação. }\end{array}$ \\
\hline Neo-estruturalista & Dutt e Lace Taylor & $\begin{array}{l}\text { Produtos gerados a partir de } \\
\text { diferentes estruturas de } \\
\text { mercado (mercados } \\
\text { competitivos, mercados } \\
\text { não-concorrenciais). }\end{array}$ & $\begin{array}{l}\text { Evitar a transferência de renda de mercados } \\
\text { competitivos para mercados não-concorrenciais } \\
\text { através da modificação da estrutura produtiva. }\end{array}$ \\
\hline
\end{tabular}


divergência de renda entre os grupos. Dutt (DUTT, 1990; DUTT, 2006) e Taylor (2003) são contribuições importantes nessa literatura.

Para facilitar a comparação das correntes teóricas exploradas nesta seção e resumir seus principais aspectos, elaborou-se a Tabela 2.1. Ressalte-se que o nome dado a cada modelo está associado aos autores que foram considerados representativos e sintetizados neste estudo, que não tem como objetivo fazer uma extensa revisão de literatura de todos os modelos. Assim, outros autores e outras análises de cada modelo podem ter sido excluídos por uma mera questão de foco do estudo. Desta forma, a Tabela 2.1 não tem como objetivo excluir análises ou autores dos modelos mas apenas fazer uma síntese para este estudo.

\subsection{Metodologia empírica adotada e fonte de dados}

A metodologia que usaremos neste trabalho consistirá no cálculo de índices que medem a renda média ponderada dos países que exportam (PRODYX) ou importam (PRODYM) cada bem e a partir deles construir outros dois índices que medem a renda associada à pauta exportadora (EXPY) e a renda associada à pauta importadora (IMPY) para cada país na década de 2000. O cálculo do índice que mede a renda média dos países que exportam determinado bem (PRODYX) e a renda associada à pauta exportadora (EXPY) foram baseados no trabalho de Hausmann, Hwang e Rodrik (2005) para o período 1992 a 2003, basicamente a década de 1990.

Este trabalho difere ao calcular os estimadores para a década de 2000 (2000-2008). Além disso, também são construídos PRODYM (índice que mede a renda média dos países que importam cada bem) e IMPY (renda associada à pauta importadora), que pode ser uma variável importante para o desenvolvimento quando consideramos, por exemplo, o processos de Substituição de Importações, ou a relevância de modelos com Inovações Industriais Intencionais, ou de Modelos de Restrição Externa, já que nestes modelos o que se importa tem consequências no desempenho das nações.

Os testes empíricos a partir dos dois trabalhos, Hausmann, Hwang e Rodrik (2005) e este ensaio, têm semelhanças e diferenças, pois, por um lado, ambos desejam mostrar a importância de EXPY na determinação do nível de renda e do crescimento para um painel de dados. No entanto, o trabalho de Hausmann, Hwang e Rodrik (2005) direcionam o estudo empírico para tentar provar um canal específico de transmissão entre EXPY e Produto, que é o canal de Cost Discovery. Já este trabalho objetiva usar essa metodologia para discutir os diferentes canais apontados por diversas vertentes da teoria econômica expostos na seção 2.2. Além disso, este 
trabalho reconhece que a estrutura produtiva, ou aquilo que os países produzem, também possa estar refletida nas importações, e, assim, tem dois índices adicionais para fazer essa discussão: PRODYM e IMPY, explorando suas relações com PRODYX e EXPY. Portanto, com objetivos diferentes e índices adicionais, este trabalho não será apenas uma reprodução de Hausmann, Hwang e Rodrik (2005) para um período mais recente, ainda que semelhanças devam existir.

Serão utilizados dados do COMTRADE (Harmonized System 1996) com quatro dígitos de desagregação para 143 países e 1240 produtos exportados e importados. Para cada um destes 1240 produtos calcularemos a renda média ponderada dos países que exportam determinado bem $\left(\mathrm{PRODYX}_{k}\right)$ e a renda média ponderada dos países que importam determinado bem $\left(\right.$ PRODYM $_{k}$ ). Os dados de renda per capita, em dólares constantes do ano 2000, foram extraídos do WDI (World Development Indicators), assim como os demais indicadores que serão utilizados como controle. Calcularemos PRODYX $_{k}$ e PRODYM $_{k}$ para o ano de 2005 e depois EXPY e IMPY para toda a década. Assim, a renda associada à determinado produto exportado é dado por:

$$
\operatorname{PRODYX}_{k}=\sum_{j} \frac{\frac{x_{j k}}{X_{j}}}{\sum_{j} \frac{x_{j k}}{X_{j}}} Y_{j}
$$

onde o numerador do peso, $\frac{x_{j k}}{X_{j}}$, é o valor exportado do produto pelo país $j$ sobre o valor total das exportações do país $j\left(X_{j}\right)$ ou, em outras palavras, o peso do produto nas exportações do país. O denominador do peso, $\sum_{j} \frac{x_{j k}}{X_{j}}$, agrega o peso do produto entre todos os países. Assim, o índice representa uma média ponderada do PIB per capita ou a importância revelada do produto exportado. Note-se que esta ponderação evita que o tamanho do país distorça os pesos calculados.

Esta metodologia tem um aspecto muito importante: ao invés de pré-definir o que é importante na geração de renda (como por exemplo, produtos de alta tecnologia, produtos industriais, entre outras definições que devem se modificar ao longo do tempo), a metodologia permite calcular os produtos que geram mais ou menos renda, sem nenhuma pré-definição e sem precisar definir nenhum paradigma tecnológico, uma vez que este se apresentará na importância revelada do produto exportado.

Exatamente da mesma forma para as importações, pode-se calcular a renda média dos países que importam determinado bem $\left(\mathrm{PRODYM}_{k}\right)$ :

$$
\operatorname{PRODYM}_{k}=\sum_{j} \frac{\frac{m_{j k}}{M_{j}}}{\sum_{j} \frac{m_{j k}}{M_{j}}} Y_{j}
$$

onde o numerador do peso, $\frac{m_{j k}}{M_{j}}$, é o valor importado do produto pelo país $j$ sobre o valor total 
das importações do país $j\left(M_{j}\right)$; ou, em outras palavras, o peso do produto nas importações do

país. O denominador do peso, $\sum_{j} \frac{m_{j k}}{M_{j}}$, agrega o peso do produto entre todos os países. Assim, o índice representa uma média ponderada do PIB per capita dos países que importam determinado bem ou a importância revelada do produto importado.

Uma vez calculado o PRODYX e o PRODYM para cada um dos 1240 produtos, calculamos a renda associada à pauta exportadora e importadora para cada país entre 2000 e 2008:

$$
\begin{aligned}
\operatorname{EXPY}_{j} & =\sum \frac{x_{j k}}{X_{j}} \text { PRODYX }_{k} \\
\mathrm{IMPY}_{j} & =\sum \frac{m_{j k}}{M_{j}} \mathrm{PRODYM}_{k}
\end{aligned}
$$

onde $\mathrm{EXP}_{j} \mathrm{e} \mathrm{IMPY}_{j}$ são as médias ponderadas de PRODYX e PRODYM para cada país, e os pesos são simplesmente as participações dos produtos no total de exportações ou importações.

Outra ressalva que deve ser feita é sobre a importância da desagregação em um grande número de produtos e o problema da endogeneidade. A relação entre EXPY e IMPY e a renda existe por construção, já que PRODY é construído com base na renda. Entretanto, ele é construído baseado em todos os países que exportam ou importam determinado bem. Assim, se calculamos a renda associada à exportação ou importação de cada produto, para muitos produtos e o máximo de países possível, e depois agregamos por país, EXPY e IMPY não deveriam apresentar uma relação sistemática com a renda daquele país, a não ser que aquilo que se exporta ou importa seja realmente importante para renda per capita.

Dessa maneira, utilizar-se-á EXPY, IMPY, PRODYX, PRODYM, e demais estatísticas dessa base para realizarem-se experimentos econométricos e, assim, discutir-se algumas das questões colocadas nas seções anteriores.

\subsection{Experimentos empíricos}

\subsection{1 desagregação a 2 dígitos}

Primeiramente, serão construídos os índices PRODYX (média ponderada das rendas per capita dos países que exportam determinado bem) e PRODYM (média ponderada das rendas per capita dos países que importam determinado bem). Entretanto, far-se-á este cálculo com uma desagregação de apenas 2 dígitos no sistema BEC, o que totaliza apenas 14 setores para os 143 países da amostra para o ano de 2005.

Embora essa desagregação mais baixa inviabilize testes econométricos mais sofisticados, 


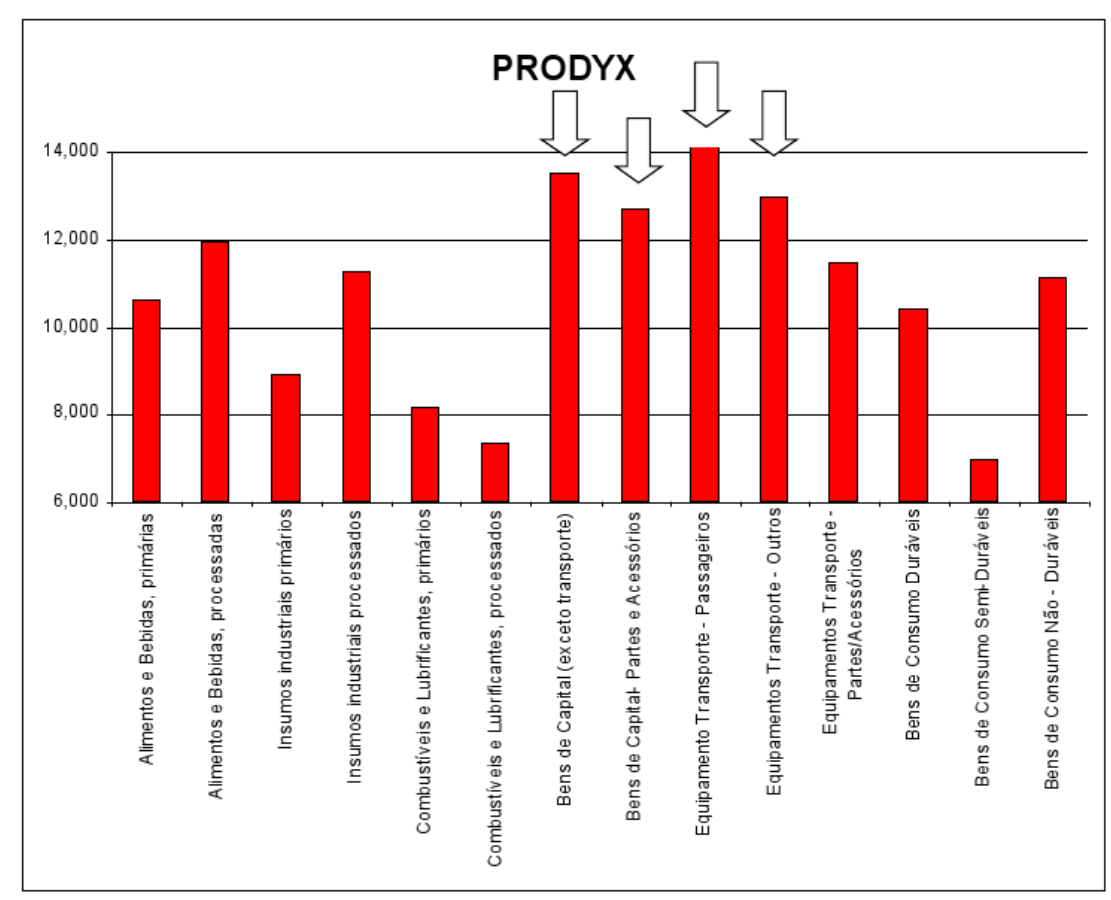

Figura 2.1: PRODYX 2 dígitos.

uma vez que quanto menor a desagregação maior a endogeneidade, o exercício é interessante, pois é possível expressar graficamente todos os PRODYX e PRODYM, facilitando algumas interpretações que se agregarão às considerações do próximo exercício, mais apurado, porém, onde é mais difícil expor todos os resultados. Enfim, esta será a primeira incursão no estudo empírico deste ensaio.

O estudo será iniciado com o cálculo de PRODYX para 2005, cujos resultados podem ser visualizados na Figura 2.1.

Note-se que em uma primeira abordagem, ainda muito preliminar para traçar conclusões mais definitivas, as rendas mais elevadas estão associadas à exportação de bens de capital e material de transporte. Por outro lado, em média, rendas mais baixas estão associadas a Combustíveis e Bens de Consumo semi-duráveis. Nesse primeiro exercício simplificado do modelo já caberia uma pergunta: se um país tem vantagens comparativas em bens de consumo semiduráveis e combustíveis, deve ele simplesmente explorá-las? Por existir essa diferença de renda entre exportadores de diferentes produtos, será que outras variáveis (como capital humano, instituições, por exemplo) operaram sistematicamente para que esse resultado ocorresse?

Note-se também que a renda média dos exportadores de alimentos e bens não-duráveis vem crescendo em 2009 em relação a 1999 (ver Anexo A), mas, como já foi dito, os exportadores de bens de capital e material de transporte têm de longe uma renda média mais alta. Além disso, os bens processados estão, em geral, relacionados a rendas mais altas. 


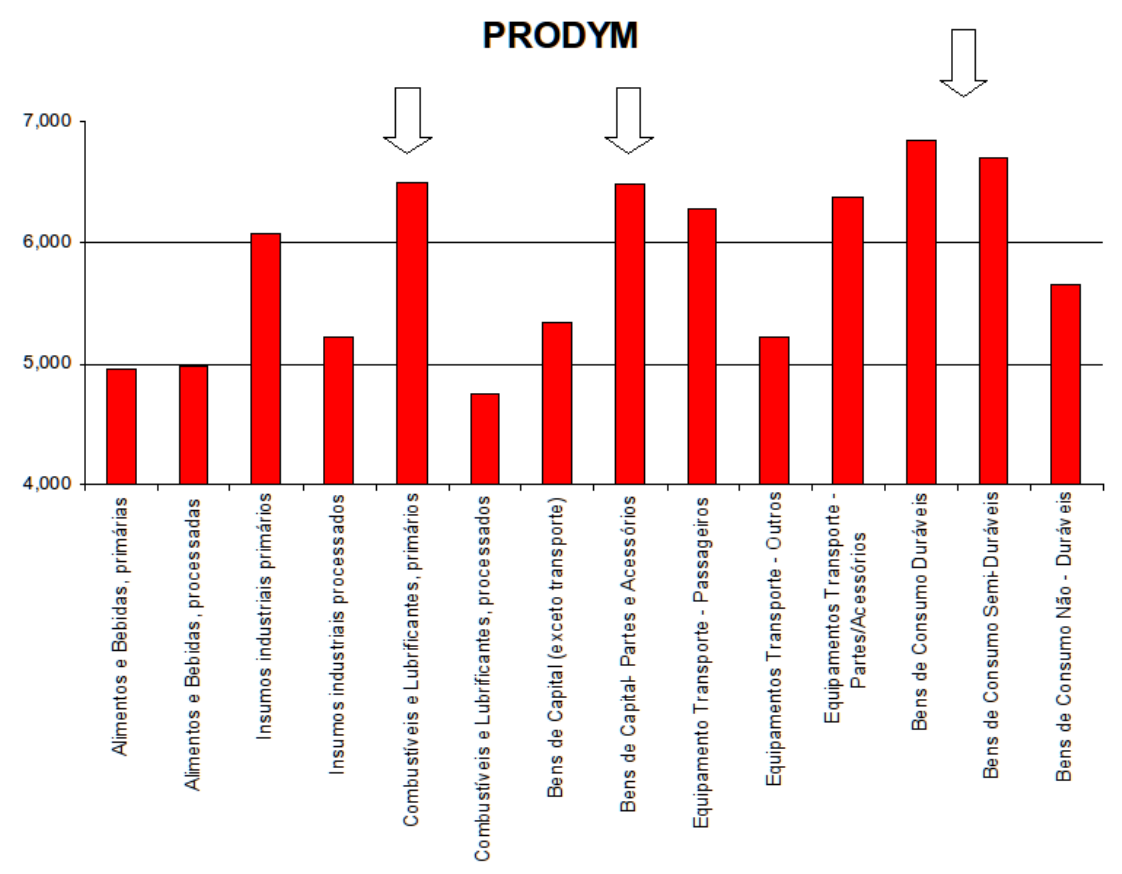

Figura 2.2: PRODYM 2 dígitos.

Agora prosseguir-se-á, com as mesmas ressalvas feitas para as exportações, com o cálculo de PRODYM para 2005 cujos resultados podem ser visualizados na Figura 2.2.

Neste caso, países com renda média mais alta importam partes e acessórios de bens de capital, mas não o bem de capital final, podendo indicar alguma transferência de tecnologia. Rendas altas estão associadas à importação de combustíveis primários e bens de consumo.

\subsection{2 desagregação a 4 dígitos}

Agora será realizado o estudo empírico principal a partir dos dados do CONTRADE Harmonized System 1996 com desagregação a 4 dígitos. A partir dele serão calculados PRODYX (média ponderada das rendas per capita dos países que exportam determinado bem) e PRODYM (média ponderada das rendas per capita dos países que importam determinado bem) para 1240 produtos em 143 países e com base nestes índices calcular-se-ão EXPY (renda associada a pauta exportadora) e IMPY (renda associada a pauta importadora) para esses 143 países. A partir desses índices far-se-ão alguns trabalhos econométricos no sentido de verificar se EXPY ou IMPY são importantes para a determinação da renda per capita e qual sua relação com crescimento econômico.

Primeiramente, serão calculados PRODYX (média ponderada das rendas per capita dos países que exportam determinado bem) e PRODYM (média ponderada das rendas per capita dos 
Tabela 2.2: Maiores e menores PRODYX.

\begin{tabular}{|c|c|c|c|}
\hline Maiores PRODX & \multicolumn{3}{|c|}{ Menores PRODX } \\
\hline 1 Tubos de níquel, Pipas e Tubos e acessórios para Pipas & 28,705 & Produtos vegetais não especificados anteriormente & 806 \\
\hline 2 Microscópios, exceto aparelhos ópticos, de difraçāo & 28,291 & Minérios de alumínio e seus concentrados & 792 \\
\hline 3 Outros compostos heterocíclicos com átomo de oxigênio heteroátomo(s) apenas & 25,105 & Frutas conservadas transitoriamente, não pronto comer & 770 \\
\hline 4 Automotor ferroviários / veiculos eléctricos nāo (locomotivas) & 24,589 & Bagaços de amendoime outros resíduos sólidos & 756 \\
\hline 5 Gravuras, estampas e litografias & 24,123 & Minérios de tungsténio e seus concentrados & 707 \\
\hline 6 Selos usados e selos fiscais, primeiro dia cobre, etc & 23,885 & Minérios de nióbio, tântalo vanádio zircônio, concentrados & \\
\hline 7 Aparelhos ortopédicos & 23,774 & Tecidos de fibras de juta ou de outras liberianas de 53,03 & 679 \\
\hline 8 Peparaçōes químicas para uso fotográfico & 23,528 & Sementes e frutos oleaginosos nes & 675 \\
\hline 9 Peças e acessórios de armas & 23,455 & Algodão, não cardado nem penteado & 665 \\
\hline 10 Metais comuns folheados ou chapeados de prata, semi-manufaturados & 23,404 & Chá & 662 \\
\hline 11 Acetais e hemiacetais, derivados & 23,372 & Copra & 624 \\
\hline 12 Equipamentos eletrônicos de gravaçāo de som & 23,122 & Cloves (frutos, flores e pedúnculos) & 576 \\
\hline 13 Hormônios, derivados, não especificados anteriormente usado esteróides e hormônios & 22,923 & Cascas, fibras, cascas e residuos & 568 \\
\hline 14 Hidrogenados, sulfonados nitrados e aldeídos & 22,845 & Juta, nāo envira outros, em bruto ou trabalhado, fiado & 500 \\
\hline 15 Metais, folheados ou chapeados de platina, semi-manufaturados & 22,828 & Fios de juta, de fibras liberianas exceto linho, cânhamo, rami & 496 \\
\hline 16 Música, manuscrita ou impressa & 22,800 & Minérios de cobalto e seus concentrados & 471 \\
\hline 17 Fios de ligas de aço, excepto aço inoxidável & 22,770 & Sisal, Agave, em bruto e não rodou, estopas e & 446 \\
\hline 18 Teares & 22,278 & Peças e acessórios para bicicletas, motos, etc & 403 \\
\hline 19 Reagentes compostos de diagnóstico ou de laboratório, ne & 22,020 & Algodão cardado, penteado & 385 \\
\hline 20 Mecanismos de relojoaria, completos e montados & 21,987 & Baunilha & 301 \\
\hline 21 Ferramenta de pratos, dicas, etc, carboneto de metal sinterizado, cermet & 21,976 & Cacau inteiro ou partido, em bruto ou torrado & 296 \\
\hline 22 Molas de cobre & 21,941 & Minérios de estanho e seus concentrados & 50 \\
\hline 23 As fibras ópticas, lentes, espelhos, prismas, etc & 21,775 & Cocos, castanha do Brasil e castanha de caju, frescos ou secos & (II \\
\hline 24 Papel, papelão, argila, revestido inorgânico, pelo menos, um lado & 21,704 & Urânio ou de tório e seus concentrados & by \\
\hline 25 Aparelhos Amolar, rectificar, brunir, moagem máquinas-ferramentas & 21,684 & Materiais vegetais & \\
\hline
\end{tabular}

países que importam determinado bem) para 1240 produtos da amostra. Os maiores e menores PRODYX e os maiores e menores PRODYM estão nas tabelas 2.2 e 2.3 , e a tabela completa com todos os PRODX e PRODY por produto encontra-se no Anexo B.

A primeira observação é em relação à variância da amostra. Enquanto o produto com maior EXPY está associado a um nível ponderado médio de US\$28.705, o produto com menor EXPY está associado a um nível ponderado médio de apenas US\$231, o que significa um alto desviopadrão de US\$ 5.563. Essa é a primeira evidência que sugere que a pauta tenha um papel importante, ou seja, sistematicamente, alguns produtos estão associados a um nível mais alto que outros, e esta diferença não é irrelevante. Caso fosse uma questão de explorar vantagens comparativas, não haveria razão para uma diferença de renda tão grande entre produtos, uma vez que o país que tem vantagens comparativas em Material Vegetal (menor PRODYX) teria ganhos de renda em explorá-la. Entretanto verifica-se que os países que exportam Material Vegetal tem a renda média 12.4 vezes menor do que os países que exportam Tubos ou Pipas de Niquel (maior PRODYX). Essa é uma forte evidência de que exportar alguns produtos é melhor que exportar outros.

A segunda observação é em relação à natureza dos bens com maiores e menores PRODYX. Os produtos com maiores PRODYX são, em geral, bens de maior conteúdo tecnológico associados a materiais de laboratório, fibras óticas e alguns bens de capital como automotores ferroviários, ou bens de luxo como antiguidades, obras de arte, selos antigos. Já os bens com menor PRODYX são todos commodities primárias ou industriais, várias delas ligadas à industria têxtil - evidência que complementa o resultado de baixa renda associada a exportação de bens semi-duráveis que verificamos no experimento com dois dígitos. 
Tabela 2.3: Maiores e menores PRODYM.

\begin{tabular}{|c|c|c|}
\hline Maiores PRODM & Menores PRODM & \\
\hline 1 Residuos ou sucata de metais preciosos & 27,045 Trigo e trigo com centeio & 2098 \\
\hline 2 Platina, em formas brutas, semimanufaturadas ou em pó formas & 26,848 Tubos de chumbo, tubos e conexões & 2076 \\
\hline 3 Antiguidades com mais de cem anos & 26,557 Óleo de soja, fracções, não quimicamente modificados & 2035 \\
\hline 4 Residuos ou sucata de níquel & 25,797 Máquinas de escrever e de máq.de processamento de texto & 2027 \\
\hline 5 Pérolas naturais ou cultivadas, não montados nem engastados & 24,572 Malte & 2013 \\
\hline 6 Lenha, madeira em estilhas ou em particulas, residuos de madeira & 22,540 Trigo ou farinha de trigo com centeio & 1994 \\
\hline 7 Cavalo, burro, carne porco, frescas, refrigeradas ou congeladas & 22,253 Aparas e outros desperdícios de couros & 1891 \\
\hline 8 Metal cinzas ou residuos contendo ferro ou aço, & 21,974 Fósforos & 1887 \\
\hline 9 Gravuras, estampas e litografias & 21,820 Farinhas de cereais, excepto trigo ou de trigo c/centeio & 1872 \\
\hline 10 Precioso metal colóides, compostos e amálgamas & 21,580 Ampolas de vidro para garrafas térmicas & 1844 \\
\hline 11 A poeira e o pó de pedras preciosas ou semi-preciosas & 21,451 Tanques e outros veiculos blindados de combate & \\
\hline 12 Titânio e suas obras, resíduos ou sucata & 20,875 Revestimentos de pavimentos, com uma base de papel & 1760 \\
\hline 13 Selos usados e selos fiscais, primeiro dia uso, etc & 20,729 Cianetos & 1726 \\
\hline 14 Ossos e núcleos córneos, em bruto ou simplesmente trabalhados & 20,722 Máquinas para limpar,classificar sementes, grãos, legumes & 1685 \\
\hline 15 Elemento químico bolachas e um composto dopado para a eletrônica & 19,569 Pirites de ferro & 1667 \\
\hline 16 Ferramenta de pratos, dicas, etc, carboneto de metal sinterizado, cimento & 19,101 Minérios de estanho e seus concentrados & 1518 \\
\hline 17 Coleções e espécimes para colecções & 19,032 Amianto & 1299 \\
\hline 18 Trabalhos ardósia, ardósia aglomerada, obras & 18,942 Especial navios efeito, navios, nes & 1075 \\
\hline 19 Crustáceos, moluscos, etc, preparados ou conservados & 18,867 Estearina, estearina e óleo, óleo de sebo natural & \\
\hline 20 Música, manuscrita ou impressa & 18,726 Juta, não envira outros, em bruto ou trabalhado, fiado & 858 \\
\hline 21 Os elementos radioativos, isótopos, os compostos e misturas & 18,549 Documentos de propriedade (titulos etc), os selos não utiliz. & 50 \\
\hline 22 Pós e escamas, de níquel & 18,499 Gás de hulha, gás de água, etc (não hidrocarbonetos gasosos) & 655 \\
\hline 23 Camisolas e pulôveres, cardigans, etc, tricô ou crochê & 18,469 Mates de cobre, cobre cimento (precipitado de cobre) & 586 \\
\hline 24 Correeiro de celeiro, de qualquer material & 18,421 Navios e outras estruturas flutuantes, para desmantelar & 540 \\
\hline 25 Hormônios, derivados, não especificados anteriormente usado esteróides como os hormô & 18,326 Peças e acessórios para bicicletas, motos, etc & 8 \\
\hline
\end{tabular}

Vejamos agora o que ocorre com as importações ou PRODYM.

A mesma observação em relação à variância da amostra vale para as importações. Ou seja, PRODYM varia de US\$ 87 a US\$27.045 com um desvio-padrão de US\$3.880, significativamente menor que o das exportações, mas ainda bastante relevante.

Entretanto, quanto ao padrão dos maiores e dos menores PRODYM é mais difícil encontrar um padrão tão conclusivo como nas exportações. Entre os maiores PRODYM existem produtos de alta tecnologia associados a altos PRODYX, como hormônios, elementos químicos, alguns bens de luxo; mas também existem produtos de baixo conteúdo tecnológico, como carnes congeladas, madeira, entre outros. Os menores PRODYM parecem estar mais correlacionados a commodities industriais e agrícolas e produtos da indústria têxtil, mas não somente a commodities. Ou seja, o padrão é mais difícil de ser detectado.

Se os maiores PRODYX fossem os menores PRODYM (inversamente relacionados) isso nos levaria a conclusão de que produtos bons de exportar não seriam bons de importar. Já se os maiores PRODYX estivessem correlacionados aos maiores PRODYM (diretamente relacionados), isso seria uma evidencia de um alto comercio intra-indústria. Entretanto, nenhum desses padrões aparece claramente nos dados como podemos verificar na Figura 2.3 que relaciona PRODYX e PRODYM por produto.

Uma vez que já foi demonstrado o que ocorre com os produtos exportados e importados, passaremos à análise por país. Ou seja, se analizará o comportamento de EXPY e IMPY por país, sendo eles indicadores da competitividade externa do país nas exportações e nas importações. Primeiro, as tabelas 2.4 e 2.5 mostram os maiores e menores EXPY e os maiores e 


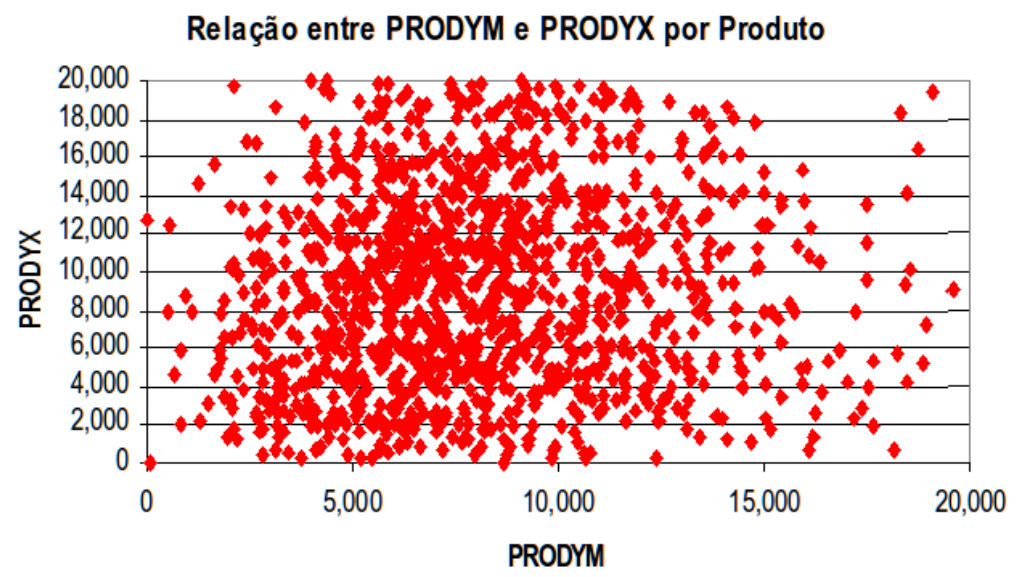

Figura 2.3: PRODYX e PRODYM por produto.

menores IMPY; uma tabela completa consta no Anexo C.

Tabela 2.4: Maiores e menores EXPY.

\begin{tabular}{r|lr|lr}
\hline & \multicolumn{2}{|c|}{ Maiores EXPY } & \multicolumn{2}{c}{ Menores EXPY } \\
\hline \hline $\mathbf{1}$ & Japão & 14.153 & Zâmbia & 3.286 \\
$\mathbf{2}$ & Irlanda & 13.746 & Mongólia & 3.247 \\
$\mathbf{3}$ & Suiça & 13.688 & Gana & 2.832 \\
$\mathbf{4}$ & Suécia & 13.429 & Kiribati & 2.532 \\
$\mathbf{5}$ & Alemanha & 13.239 & Benin & 2.088 \\
$\mathbf{6}$ & Finlândia & 13.191 & Ruanda & 2.086 \\
$\mathbf{7}$ & Cingapura & 13.185 & Ilhas Salomão & 2.086 \\
$\mathbf{8}$ & Coréia & 12.995 & Mali & 2.027 \\
$\mathbf{9}$ & EUA & 12.921 & Guiné & 2.021 \\
$\mathbf{1 0}$ & Reino Unido & 12.707 & Malawi & 1.798 \\
$\mathbf{1 1}$ & Eslovênia & 12.317 & Burundi & 1.787 \\
$\mathbf{1 2}$ & Áustria & 12.293 & Etiópia & 1.658 \\
$\mathbf{1 3}$ & França & 12.257 & Burkina Faso & 1.644 \\
$\mathbf{1 4}$ & China, Hong Kong & 12.188 & São Tomé e Príncipe & 973 \\
$\mathbf{1 5}$ & República Checa & 12.056 & Guiné-Bissau & 372 \\
\hline $\mathbf{2 6}$ & China & 10.970 & \multicolumn{2}{|}{} \\
$\mathbf{4 1}$ & África do Sul & 9.177 & \multicolumn{2}{|}{} \\
$\mathbf{4 6}$ & Brasil & 8.409 & & \\
$\mathbf{5 2}$ & Rússia & 8.052 & & \\
$\mathbf{5 3}$ & Índia & 8.020 & & \\
\hline
\end{tabular}

Primeiramente fica evidente que países mais competitivos na sua pauta exportadora são também mais competitivos na sua pauta importadora. Países ricos têm maiores EXPY e maiores IMPY, enquanto países pobres, em sua maioria africanos, têm os piores EXPY e IMPY. A correlação positiva entre EXPY e IMPY por país, a qual não foi verificada por produto, fica evidente na Figura 2.4. ${ }^{6}$

Entretanto, a correlação entre a competitividade externa e o nível de renda per capita precisa ser melhor investigada, assim como sua relação com crescimento econômico. Primeiramente

\footnotetext{
${ }^{6}$ Ressalte-se que se verificou uma correlação, não é possível inferir a direção da casualidade.
} 
Tabela 2.5: Maiores e menores IMPY.

\begin{tabular}{r|lr|ll}
\hline & \multicolumn{2}{|c|}{ Maiores IMPY } & \multicolumn{2}{c}{ Menores IMPY } \\
\hline \hline $\mathbf{1}$ & China, Hong Kong & 10.635 & Guiana, Honduras & 5.839 \\
$\mathbf{2}$ & Cingapura & 10.037 & Burkina Faso & 5.596 \\
$\mathbf{3}$ & Suiça & 10.029 & Bangladesh & 5.541 \\
$\mathbf{4}$ & Japão & 9,921 & Kiribati & 5.527 \\
$\mathbf{5}$ & Israel & 9.852 & Gâmbia & 5.455 \\
$\mathbf{6}$ & Irlanda & 9.740 & Togo & 5.436 \\
$\mathbf{7}$ & EUA & 9.608 & Iêmen & 5.412 \\
$\mathbf{8}$ & Reino Unido & 9.547 & São Tomé e Príncipe & 5.380 \\
$\mathbf{9}$ & Filipinas & 9.495 & Benin & 5.327 \\
$\mathbf{1 0}$ & Alemanha & 9.462 & Zimbábue & 5.239 \\
$\mathbf{1 1}$ & Coréia & 9.405 & Níger & 5.185 \\
$\mathbf{1 2}$ & China & 9.403 & Mali & 4.984 \\
$\mathbf{1 3}$ & China, Macau & 9.342 & Malawi & 4.739 \\
$\mathbf{1 4}$ & Emirados Árabes & 9.287 & Guiné-Bissau & 4.454 \\
$\mathbf{1 5}$ & Bélgica & & Mauritânia & 3.848 \\
\hline $\mathbf{3 2}$ & África do Sul & 8.845 & & \\
$\mathbf{3 4}$ & Índia & 8.761 & & \\
$\mathbf{3 6}$ & Brasil & 8.655 & & \\
$\mathbf{5 1}$ & Rússia & 8.206 & & \\
\hline
\end{tabular}

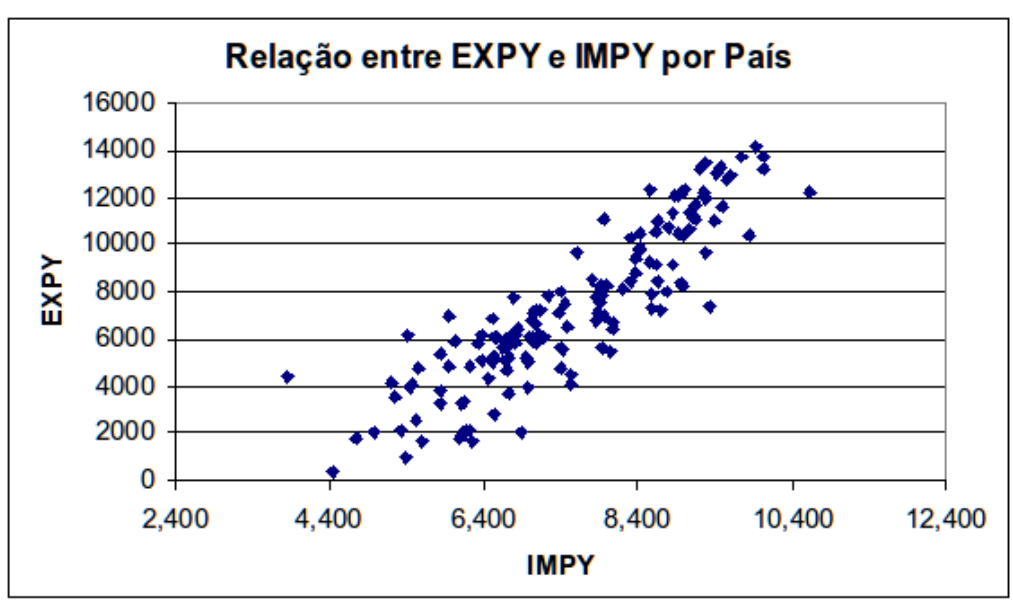

Figura 2.4: EXPY e IMPY por país.

serão mostrados os gráficos das figuras 2.5 e 2.6, que indicam uma correlação positiva entre EXPY e IMPY e o nível de renda per capita.

Além de visualizar a correlação, podemos associar a posição das economias e o crescimento econômico. Países abaixo da linha de tendência, como, por exemplo, a China, apresentam uma competitividade da pauta exportadora e importadora muito maior que a condizente com sua renda per capita. Assim, a tendência do país é crescer mais do que os demais para atingir uma renda per capita maior. Já países como EUA, Japão, Luxemburgo, Finlândia, tem a renda maior que o condizente com sua competitividade externa e, portanto, devem crescer menos em relação aos demais países. 


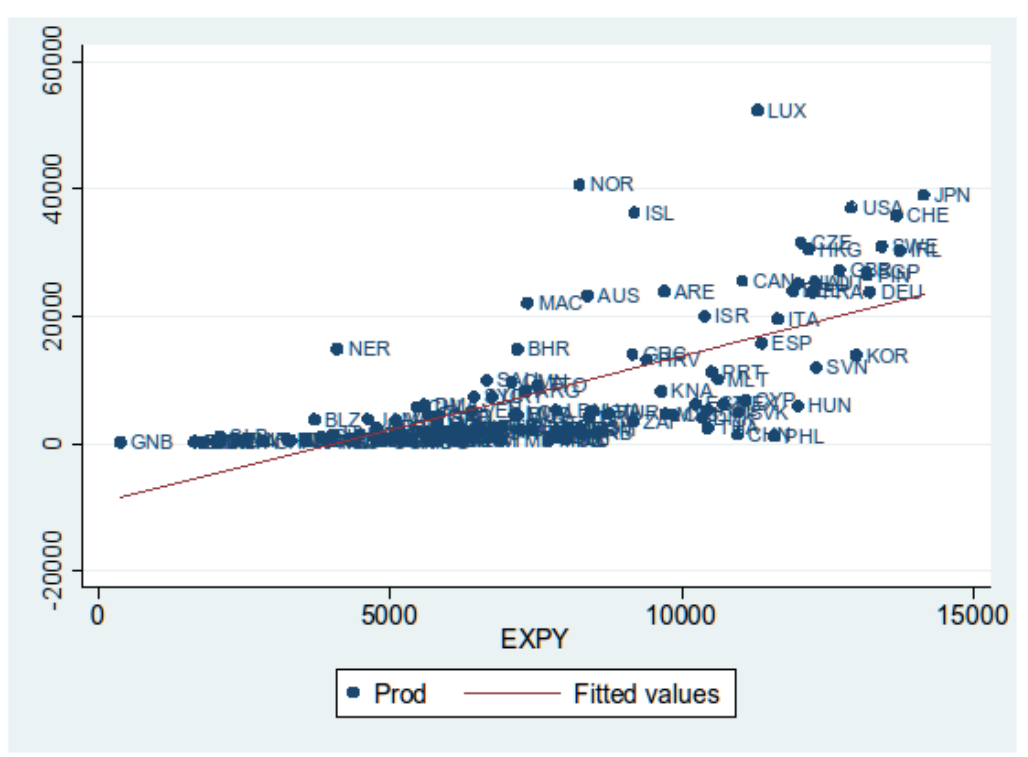

Figura 2.5: EXPY e renda per capita por país.

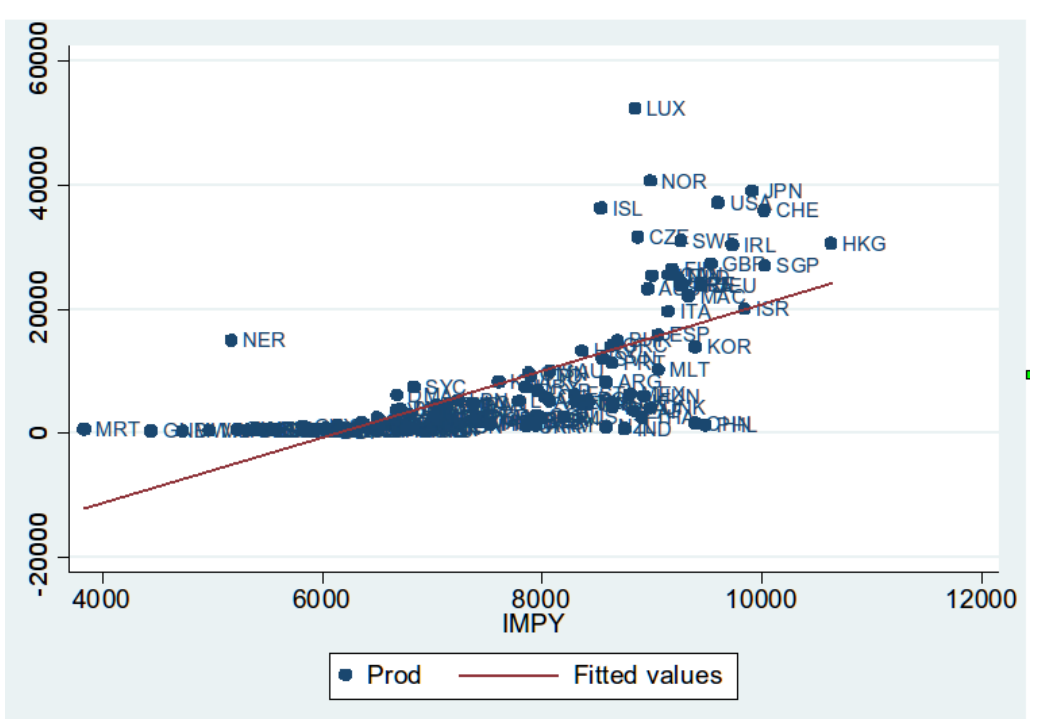

Figura 2.6: EXPY e renda per capita por país.

Entretanto, devido à endogeneidade e omissão de variáveis relevantes para a determinação do nível de renda per capita, faz-se necessário um teste mais formal. Dessa forma, serão testados três modelos para exportação (EXPY) e os mesmos três modelos para importação (IMPY). Assumiremos que as variáveis relevantes para a determinação do nível de renda são aquelas colocadas pela literatura mais convencional do modelo de Solow, ou seja, faremos uma regressão do nível de renda real, como variável dependente, e as variáveis independentes seriam: uma medida de Capital Físico, uma medida de Capital Humano, uma medida de Trabalho e uma medida de Instituições e EXPY/IMPY. ${ }^{7}$ Em outras palavras, deseja-se mostrar que a compe-

\footnotetext{
${ }^{7}$ Para medir o Capital Físico usou-se a Formação Bruta de Capital Físico como percentual do PIB. Para medir o Capital Humano usou-se a porcentagem dos que estão no ensino primário entre os que estão na idade de frequentar
} 
titividade externa tal como medida por EXPY e IMPY são variáveis omitidas nesta linha de modelos.

Para isso serão testados três modelos. O primeiro é uma cross-section para o ano de 2005. O segundo modelo é uma pooled regression para os anos de 2004-2008; ou seja, os dados em painel são estimados como uma regressão simples, sem considerar o efeito específico de cada país. Finalmente, estimaremos o painel de países entre 2004-2008 considerando o efeito específico de cada país, seja por efeito fixo, seja por efeito aleatório, conforme o indicado pelo teste de Hausman, presente no Anexo D. Além disso, uma descrição formal de estimação por efeito fixo e efeito aleatório e do teste de Hausman pode ser encontrado no Anexo E. Os resultados serão expostos nas tabelas 2.6 e 2.7 .

Tabela 2.6: Resultados do teste dos modelos exportação.

\begin{tabular}{|c|c|c|c|c|c|c|}
\hline \multicolumn{7}{|c|}{ Relevância Pauta Exportadora } \\
\hline & \multicolumn{2}{|c|}{$\begin{array}{l}\text { Modelo } 1 \\
2005\end{array}$} & \multicolumn{2}{|c|}{$\begin{array}{c}\text { Modelo } 2 \\
\text { Pooled Reg. 2004-08 }\end{array}$} & \multicolumn{2}{|c|}{$\begin{array}{c}\text { Modelo } 3 \\
\text { Efeito Fixo 2004-08* }\end{array}$} \\
\hline & Coefic. & Prob. & Coefic. & Prob. & Coefic. & Prob. \\
\hline EXPY & 1.74 & 0.00 & 1.37 & 0.00 & -0.2853 & 20.00 \\
\hline Capital Físico** & -42.52 & 68.60 & -81.42 & 27.40 & 75.85 & 39.40 \\
\hline Capital Humano & 132.84 & 5.10 & 158.69 & 0.00 & 297.17 & 0.00 \\
\hline Instituições** & -131.15 & 0.00 & -124 & 0.00 & -65.54 & 0.20 \\
\hline Trabalho & 0.00002 & 38.80 & 0.000032 & 0.00 & 0.0000878 & 0.00 \\
\hline Tamanho País & 0.00007 & 33.90 & & & & \\
\hline$F$ & 13.73 & & 52.21 & & 11.34 & \\
\hline Prob Regressao & 0.00 & & 0.00 & & 0.00 & \\
\hline & 50.40 & & 48.07 & & & \\
\hline Soma Quad Res & 8221 & & 8835 & & & \\
\hline
\end{tabular}

A variável EXPY se mostrou significante no Modelo 1 e no Modelo 2. Já no Modelo 3 quando introduzimos o efeito específico, a significância da variável desaparece. Para diversos autores que trabalham nessa linha de modelos como Islam (1995), Hall e Jones (1999) e Ferreira, Pessoa e Velloso (2005), o efeito especifico é a Produtividade Total de Fatores que explica grande parte do crescimento atual. Os resultados deste ensaio sugerem que na Produtividade Total de Fatores, entendida como resíduo dos modelos de crescimento; ou seja, o que não pode ser explicado pelo acumulo de fatores, está embutida a competitividade externa. Em outras palavras, na caixa preta da PTF está a competitividade externa tal como medida por EXPY e IMPY, pois, somente quando introduzimos a PTF (efeito específico), a significância da competitividade externa desaparece. O mesmo resultado mantém-se para a competitividade medida pelas

ensino primário mais a porcentagem dos que estão no ensino secundário entre os que estão na idade de frequentar ensino secundário. Para medir trabalho usou-se a população total. Para medir Instituições somou-se o número de procedimentos para se abrir um negócio somado ao número de dias para validar um contrato. Além disso, em um dos modelos será considerado o tamanho do país que será simplesmente a área que o país ocupa. Todos os dados foram retirados do WDI — World Development Indicators. 
importações.

Tabela 2.7: Resultados do teste dos modelos importação.

\begin{tabular}{|c|c|c|c|c|c|c|}
\hline \multicolumn{7}{|c|}{ Relevância Pauta Importadora } \\
\hline & \multicolumn{6}{|c|}{ Variável Dependente : PIB Per Capita US\$ Constantes } \\
\hline & \multicolumn{2}{|c|}{$\begin{array}{l}\text { Modelo } 1 \\
2005 \\
\end{array}$} & \multicolumn{2}{|c|}{$\begin{array}{c}\text { Modelo } 2 \\
\text { Pooled Reg. 2004-08 }\end{array}$} & \multicolumn{2}{|c|}{$\begin{array}{c}\text { Modelo 3 } \\
\text { Efeito Aleatorio 2004-08* }\end{array}$} \\
\hline & Coefic. & Prob. & Coefic. & Prob. & Coefic. & Prob. \\
\hline IMPY & 1.06 & 4.20 & 0.694 & 0.80 & -0.0678 & 61.20 \\
\hline Capital Físico ** & -119.00 & 27.00 & -123.57 & 11.40 & -32.07 & 62.15 \\
\hline Capital Humano & 247.64 & 0.00 & 263.39 & 0.00 & 283.49 & 0.00 \\
\hline |Instituições** & -96.92 & 0.00 & -115.29 & 0.00 & -96.78 & 0.00 \\
\hline Trabalho & 0.0000755 & 7.65 & 0.0000319 & 0.40 & 0.0000684 & 0.00 \\
\hline Tamanho País & 0.0000651 & 99.30 & & & & \\
\hline $\bar{F}$ & 11.11 & & 40.03 & & $\overline{13.14}$ & \\
\hline Prob Regressao & 0.00 & & 0.00 & & 0.00 & \\
\hline & 45.15 & & 43.40 & & & \\
\hline Soma Quad Res & 8648 & & 9367 & & & \\
\hline
\end{tabular}

\subsection{Teorias de crescimento em economias abertas e resulta- dos empíricos deste ensaio - algumas considerações}

A primeira teoria a ser confrontada com os dados é a Teoria das Vantagens Comparativas pela sua própria posição de principal teoria de Comércio Exterior. Neste sentido, a própria significância de IMPY e EXPY já questiona os modelos de crescimento baseados em vantagens comparativas, pois o que o país exporta e importa é significante para o crescimento. Isso significa que existem características além da dotação de fatores que fazem um produto ser melhor que o outro. Em outras palavras, mesmo controlando pela dotação de fatores, ainda assim EXPY e IMPY se mostraram significantes.

Segundo a Teoria das Vantagens Comparativas, não existiriam produtos melhores ou piores de serem comercializados, contanto que estejam em consonância com sua estrutura de custos. Entretanto, os resultados empíricos mostraram que, por exemplo, quem tem vantagens comparativas na indústria têxtil em vários de seus segmentos tem em média um nível de renda mais baixo. Por outro lado, quem tem vantagens comparativas em materiais de transporte - por exemplo, maquinário para locomotivas-, tem em média uma renda maior. Além disso, o desvio padrão entre os melhores e os piores produtos a serem exportados e importados é muito grande e sistematicamente favorável aos produtos de maior tecnologia e não às commodities.

Diante destes dados os policy makers devem fazer uso de suas vantagens comparativas, quando elas forem desfavoráveis, e importar os demais bens? Ou será que um nível de renda mais alto, e mesmo um consumo mais alto, não é obtido ao direcionar sua produção e sua 
estrutura de custos para determinada direção? Países ricos, ou que estão enriquecendo, têm, ou estão construindo, uma estrutura de comércio externo bastante competitiva.

Outra questão que se coloca é: a teoria das vantagens comparativas é sustentável na presença dessa enorme disparidade entre produtos bons e ruins para exportar e importar? A base da teoria suatenta que a melhor coisa a se fazer é produzir os bens para os quais existam vantagens comparativas e importar os demais. Entretanto, se a disparidade entre o que ela tem para exportar e o que ela quer importar é demasiadamente grande, o modelo pode tornar-se inviável e pode ser ótimo investir este diferencial de recursos para alterar as vantagens comparativas, ou seja, alterar o próprio modelo.

A segunda teoria mencionada, Modelos de Concorrência Monopolística, também merece destaque, entre outras coisas, por confrontar diretamente o Modelo Keynesiano de Restrição Externa que receberá destaque no próximo ensaio desta tese.

Segundo a Teoria de Competição Monopolística, a economia vai crescendo com base nos seus fatores de produção (para simplificar, apenas trabalho) e conforme vai crescendo, ao invés de ir reduzindo os preços dos produtos já exportados para ganhar mercado, vai aumentando a variedade dos bens que produz. Dessa forma, sua curva de oferta de produtos (exportação) está sempre se deslocando; e um estudo econométrico que não considerasse isso poderia levar à conclusão errada de que elasticidades geram produto. Como diz Krugman (1989) "The story runs as follows, Fast growing countries expand their share of world markets, not reducing the relative prices of their goods, but by expanding the range of goods that they produce as economies growth" (KRUGMAN, 1989).

Com o intuito de discutir essa teoria de comercio exterior e crescimento, convém observar as figuras 2.7 e 2.8 baseadas nos dados montados neste experimento empírico.

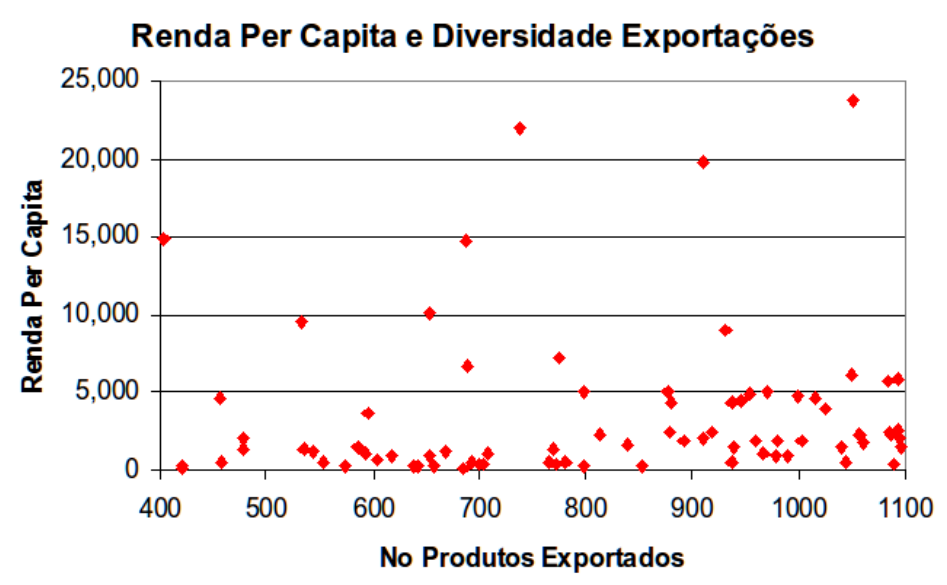

Figura 2.7: Renda per capita e diversidade exportações. 


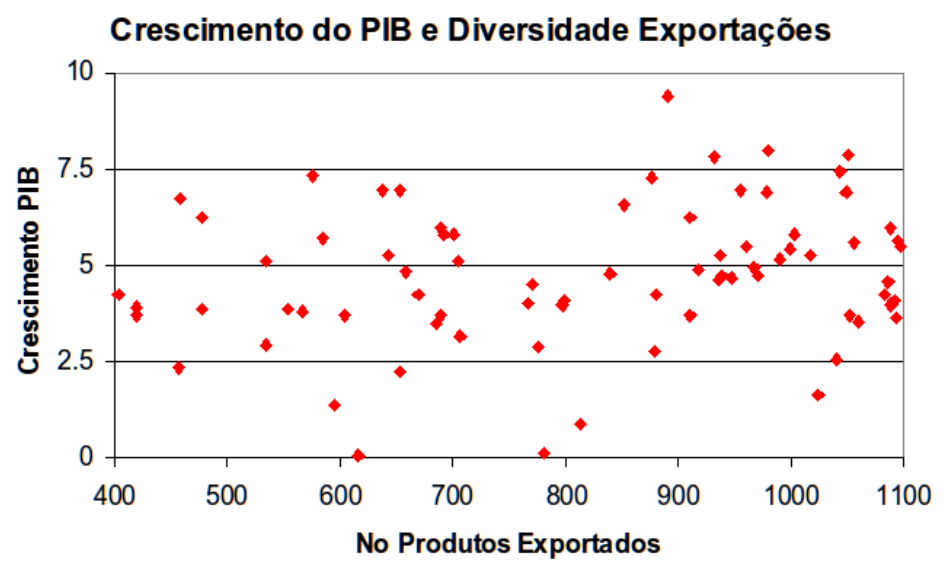

Figura 2.8: Crescimento e diversidade exportações.

Os gráficos mostram claramente que não existe uma relação sistemática entre renda per capita e número de variedades exportadas; nem entre crescimento do PIB e número de variedades exportadas (resultado mais direto do modelo). Contrariamente às previsões do modelo, existem economias com o mesmo crescimento do PIB exportando de 400 a 1100 produtos. Isso traz evidências que não corroboram a tese de que uma economia, ao longo de seu processo de crescimento, exporte uma variedade cada vez maior de bens.

Entretanto, essa conclusão poderia ser refutada por Broda e Weinstein (2004) que argumentam que o número de variedades que deveria ser computada para a discussão do modelo é da ordem de 150 mil, ou de uma desagregação de 10 dígitos. Ainda assim, uma desagregação menor deveria reduzir esse efeito, mas é difícil argumentar que anularia o efeito, pois, caso contrário, uma desagregação com 10 dígitos também poderia não ser suficiente.

Uma vez que estamos discutindo a validade de modelos com competição monopolística, seria interessante voltar às declarações de Krugman que "nega a priori que a razão de elasticidades determinem o diferencial do PIB e não vice-versa", como em um modelo de restrição externa. Primeiramente, colocamos que para uma certa desagregação de dados, o modelo de competição monopolista não explica o diferencial de crescimento entre nações. Agora vamos perguntar mais diretamente: qual a variável que se ajusta no curto prazo para o retorno do equilíbrio do Balanço de Pagamentos no Longo Prazo? As exportações mediante a uma variação no número de variedades? Ou a renda como defendido em um modelo de crescimento sob restrição externa? Essa pergunta deve ser respondida no âmbito de um modelo de séries de tempo, pois estamos tratando de Causalidade de Granger e Exogeneidade. Sendo assim, vamos perguntar qual a variável que se ajusta para o retorno do balanço de longo prazo para o Brasil no período 1930-2004. ${ }^{8}$

\footnotetext{
${ }^{8}$ Para maiores informações ver Carvalho (2005).
} 
Vamos partir da seguinte equação do balanço de pagamentos:

$$
P d X-P d R+P d K=P f M E
$$

Substituindo uma função de importação que responde a renda e câmbio, $m=\psi\left(p_{f}+e-p_{d}\right)+\pi y$ (ver no Ensaio II, equação (3.6)), na equação acima e transformando em log, temos:

$$
\log Y=\frac{1}{\pi} \log X+\frac{1}{\pi} \log (K-R)-\frac{\phi+1}{\pi} \log (P f+e-P d)
$$

onde $Y$ é a renda real, $X$ são as exportações em valores reais, $K$ é o fluxo de capitais (inverso do saldo em transações correntes), $R$ é o pagamento de serviços fatores em termos reais e $P f+E-$ $P d$ é a taxa de câmbio real.

Para estimar a equação acima por técnicas de cointegração, o primeiro passo é fazer os testes de raiz unitária, reportados no Anexo H. Verifica-se que a renda real, exportações reais e câmbio têm uma raiz unitária. No entanto, por todos os testes realizados, conclui-se que o componente financeiro $(K-R)$ é estacionário; e Johansen (1995, p. 74) observa que, se existem duas ou mais variáveis integradas de ordem 1, a cointegração é válida, mesmo se existir uma variável estacionária. Assim, prosseguir-se-á com a análise de cointegração.

Conforme reportado no Anexo $\mathrm{H}$, escolheu-se um VAR de ordem 2, o que equivale a um VEC de ordem 1. Escolher-se-á o modelo sem termos deterministas pois, além de ser o indicado pelo Principio de Pantula, implica em impor o equilíbrio do Balanço de Pagamentos no Longo Prazo, o que parece bastante razoável. Também importa notar (conforme reportado no Anexo H) que a análise dos resíduos da cointegração aponta alguns problemas de normalidade nas variáveis câmbio real e componente financeiro, e espera-se que sejam solucionados com a amostra razoavelmente grande. Como resultado, obteve-se o vetor de correção de erro da Tabela 2.8.

Tabela 2.8: VEC, Equação Equilíbrio do BP.

\begin{tabular}{c|r|r|r|r}
\hline \multicolumn{5}{c}{ Vetor de Correção de Erro } \\
Desvio Padrão em ( ) e estatística $t$ em [ ] & \\
Exportações (-1) & 1,000000 & & \\
& $-0,865604$ & & \\
Comp. financ. (-1) & {$[-17,9048]$} & & & \\
& $-0,086866$ & & & \\
Câmbio real (-1) & $-0,799211$ & & & \\
& {$[0,90581]$} & & & Câmbio \\
\hline Correção de erro: & Renda & Exportações & Comp. financ. & \\
\hline Coefic. ajustamento & $-0,012119$ & $-0,001506$ & $-0,307492$ & $-0,012658$ \\
& {$[-4,54669]$} & {$[-0,16050$} & {$[-1,28634]$} & {$[-0,91014]$} \\
\hline
\end{tabular}

A análise que nos interessa é a dos coeficientes de ajustamento. O único coeficiente de 
ajustamento diferente de zero é o da renda real e tem o sinal esperado; ou seja, a renda é a única variável que mover-se-ia no curto prazo para retornar ao equilíbrio de longo prazo.

Exportações, câmbio e o componente financeiro podem ser considerados fracamente exógenos, ou seja, nenhum desses componentes é responsável pelo retorno à situação de equilíbrio do balanço de pagamentos. Em outras palavras, se algum choque atinge o balanço de pagamentos tirando-o da trajetória de equilíbrio, a variável que irá aumentar ou diminuir para restaurar esse equilíbrio é a renda real interna. Esse resultado é uma corroboração empírica muito importante aos Modelos de Crescimento sob Restrição Externa, ou seja, a renda é endógena e se ajusta para corrigir os desequilíbrios do Balanço de Pagamentos.

Dado que exportações, câmbio e o componente financeiro são considerados fracamente exógenos, ou seja, o coeficiente de ajustamento não é estatisticamente diferente de zero, pode-se fazer um teste de Casualidade de Granger para verificar se estas variáveis podem ser consideradas fortemente exógenas. Os resultados estão reportados no Anexo H.

As exportações são fracamente exógenas e podem ser consideradas fortemente exógenas a 5\%. Isso implica que as exportações não são Granger-causadas seja pela renda, seja pelo componente financeiro, seja pelo câmbio a este nível de significância. Esses resultados invalidariam, ao menos para o Brasil a 5\% de significância, a análise de Krugman de que o ajuste do balanço de pagamentos ocorreria através do ajuste da elasticidade das exportações, que reagiria a variações de renda. Ou seja, as exportações não são responsáveis pelo ajuste do Balanço de Pagamentos.

A discussão acima, e os resultados de todo o ensaio, nos apontam na direção de usar variáveis de competitividade externa para explicar os diferenciais de PIB. Dessa forma é possível resgatar a importância do estudo dos modelos keynesianos de crescimento sob restrição externa, em que a competitividade externa do país é expressa nas elasticidades renda das importações e exportações e essas variáveis limitam o crescimento do PIB de longo prazo. Assim, os resultados deste ensaio corroboram o modelo de restrição externa, uma vez que a qualidade da pauta exportadora e importadora está embutida nas elasticidades-renda das exportações e importações, variáveis-chave do modelo. Um exercício mais apurado desse modelo será executado no próximo ensaio desta tese, mas neste ensaio vale lembrar que o que define o diferencial de crescimento entre duas economias é a razão da elasticidade de exportação sobre a elasticidade de importação; e, portanto, importação é o outro aspecto da competitividade externa, justificando parte de nosso interesse em ampliar o cálculo dos índices para importação.

É interessante discutir a Teoria das Inovações Industriais Intencionais em economias abertas, que foca na transferência de gastos em tecnologia, ou P\&D, através do Comércio Inter- 
nacional. O estudo empírico não descarta o papel da transferência tecnológica internacional, conforme a teoria das Inovações Intencionais. Caso este efeito fosse nulo, esperar-se-ia uma reta negativamente inclinada entre PRODYX e PRODYM. Entretanto ela não tem esse aspecto, indicando que em alguns setores deve estar ocorrendo um comércio intra-industrial, indicando transferência de tecnologia. Ou seja, entre bens, efeitos de substituição e complementaridades ocorrem e a ocorrência de complementaridades corroboram para que algum grau de transferência de tecnologia exista. Esse processo também pode ser visualizado no experimento de 2 dígitos onde, nas importações do setor de bens de capital, está associada uma renda maior a partes e peças que ao bem de capital final. Por fim, a própria significância de IMPY na determinação do nível de renda, embora não corrobore diretamente a teoria, pois outros efeitos podem estar atuando, nos dá uma indicação da relevância deste canal.

Da mesma forma, os dados não contradizem o canal de Falhas de Mercado. Na verdade, a ocorrência de falhas de mercado é uma explicação bastante convincente de por que EXPY e IMPY são variáveis relevantes, embora os testes elaborados não testem diretamente esses canais. Por exemplo, no caso do Cost-Discovery, a teoria de que o rumo do desenvolvimento pode depender das atividades já existentes na economia, com o desenvolvimento ganhando uma dependência temporal, é uma explicação bastante plausível da significância de EXPY e IMPY na determinação do nível de renda. Assim, o padrão de especialização é tão difícil de ser transformado que mesmo o mercado internacional indicando os bens que geram maior crescimento, as estruturas produtivas não conseguem adaptar-se com a mesma rapidez por causa do Cost Discovery. Por exemplo, como a diferença de capacidade existente requerida é muito grande entre commodities e produtos intensivos em tecnologia, um país que produz commodities tende a não gerar naturalmente a estrutura necessária para a produção de produtos de tecnologia.

Já da teoria kaldoriana podemos retirar diretamente dois pontos que condizem com os nossos dados. Um primeiro é que a transferência de recursos entre setores de menor tecnologia para setores de maior tecnologia pode ser um aspecto importante do aumento da produtividade em geral e do produto, o que é bem diferente do conceito de máxima eficiência da teoria neoclássica. Entretanto, devemos ponderar o argumento pelo período histórico que foi discutido. Podemos considerar a ideia de que apenas a indústria gerava retornos crescentes e de que a agricultura era um setor atrasado como uma ideia datada e não replicá-la na análise dos anos 2000, em que existem diversas indústrias agrícolas de alta tecnologia. Entretanto, a ideia de que alguns setores podem estar associados a uma maior produtividade é o ponto central de captar a significância de EXPY e IMPY. Outro ponto importante, corroborado pelos dados, bastante claro no experimento com 2 dígitos, é de que uma maior importância do setor de bens de capital leva a economias mais competitivas e com maior nível de renda. Por outro lado, a visão recor- 
rente de que a economia passa por um processo de causação cumulativa enfatiza canais como Cost Discovery e será particularmente estudado no Ensaio III desta tese, no qual relataremos um episódio de crescimento baseado em um modelo Kaldoriano.

A visão neo-schumpeteriana, tal como foi colocada neste ensaio a partir de alguns autores, prescreve um padrão de especialização baseado na exportação de produtos para os quais se identifique um elevado grau de oportunidade, apropriabilidade e cumulatividade tecnológica. Assim, a UNCTAD (United Nations Conference on Trade and Development) desenvolveu uma nova metodologia para classificação das mercadorias comercializadas no mercado mundial, tendo como base a intensidade tecnológica dos produtos. Os cinco grupos básicos de classificação das mercadorias, obtidos no Trade and Development Report (2002), são: Commodities Primárias (A), Intensivo em Trabalho (B), Manufatura com baixa tecnologia (C), Manufatura com média tecnologia (D), Manufatura com alta tecnologia (E), Produtos não classificados (F). Como já havíamos ressaltado, uma das grandes vantagens da metodologia utilizada neste ensaio é não precisar inferir a princípio que determinados grupos, previamente definidos, fossem melhores ou piores para crescimento econômico. Entretanto, é parte do trabalho comparar a teoria com os resultados empíricos obtidos e, portanto, verificar como uma classificação dessa natureza, proposta por correntes schumpeterianas, enquadra-se nos dados encontrados.

Neste sentido, especialmente para as exportações, os dados da Tabela 2.9 confirmam a teoria neo-schumpeteriana de que países mais ricos exportam produtos de maior conteúdo tecnológico. No caso das importações essa relação não fica clara, como era esperado, já que o elemento dinâmico da análise schumpeteriana são as exportações. Verificamos os 30 maiores e menores EXPY e os 30 maiores e menores IMPY e reclassificamos segundo o critério de conteúdo tecnológico. Obtivemos os resultados da Tabela 2.9, bastante favoráveis ao argumento schumpeteriano.

Tabela 2.9: Tabela UNCTAD.

\begin{tabular}{|lr|lr|}
\hline \multicolumn{2}{|l|}{ Maiores PRODX } & \multicolumn{2}{l|}{ Menores PRODX } \\
\hline \hline $\mathrm{C}$ & 8 & $\mathrm{~A}$ & 13 \\
$\mathrm{D}$ & 8 & $\mathrm{~B}$ & 8 \\
$\mathrm{E}$ & 11 & $\mathrm{C}$ & 8 \\
$\mathrm{~F}$ & 3 & $\mathrm{D}$ & 1 \\
\hline \multicolumn{2}{|l|l|}{ Maiores PRODM } & \multicolumn{2}{|l|}{ Menores PRODM } \\
\hline \hline $\mathrm{A}$ & 3 & $\mathrm{~A}$ & 5 \\
$\mathrm{~B}$ & 4 & $\mathrm{~B}$ & 6 \\
$\mathrm{C}$ & 5 & $\mathrm{C}$ & 13 \\
$\mathrm{D}$ & 5 & $\mathrm{D}$ & 4 \\
$\mathrm{E}$ & 3 & $\mathrm{E}$ & 1 \\
$\mathrm{~F}$ & 9 & $\mathrm{~F}$ & 1 \\
\hline
\end{tabular}


Quanto à contribuição da teoria Neo-Estruturalista, para analisar os dados que foram construídos, precisamos nos fazer duas perguntas. Primeira: os produtos com menor PRODYX vem de estruturas competitivas? Segunda: os países podem ser classificados como Norte ou Sul a dependerem dos produtos que importam ou exportam, ou seria essa uma classificação muito estrita? Bom, quanto à primeira pergunta, analisando os produtos com menor PRODYX, podese dizer que grande parte deles é produzido em um ambiente competitivo. Entretanto, quando fazemos a análise de países, verificamos que eles produzem uma infinidade de produtos que advém de mercados concorrenciais e não concorrenciais, para a maioria dos países. Enfim, seria necessária uma classificação dos países em termos de estrutura de competitividade dos bens exportados - o que já é, de certa forma, feita na literatura neo-schumpeteriana (UNCTAD, 2002). Uma classificação do tipo Norte-Sul, embora seja sabido que é uma simplificação, não é corroborada pelos dados, necessitando de certa cautela ao utiliza-lá. Dessa forma é mais adequado utilizar a modelagem em que efeitos dinâmicos das preferências geram diferentes composições de demanda, ou diferentes classificações que não apenas Norte e Sul, assim como colocam Araújo e Lima (2007). ${ }^{9}$

\subsection{Considerações finais}

As evidências constatadas e discutidas neste ensaio levam à conclusão principal de que a competitividade externa parece ser um fator fundamental para o entendimento do nível de renda per capita e da dinâmica do crescimento econômico na década de 2000. Além disso, a competitividade externa pode ter efeitos na renda através de diversos canais explorados pela teoria, e, assim, por meio de canais muito mais amplos do que os inicialmente formulados por Hausmann, Hwang e Rodrik (2005). Entretanto, em um modelo de crescimento tipo Solow essa variável é omitida e, portanto, seu efeito vai para o resíduo que é chamado de Produtividade Total de Fatores.

Assim, o legado para os próximos ensaios é exatamente se concentrar em modelos onde a competitividade externa não é apenas uma variável, por vezes omitida, mas é a variável fundamental na análise do desempenho econômico. Neste sentido, o próximo ensaio se concentrará

\footnotetext{
${ }^{9}$ Desde já gostaríamos de colocar que algumas análises ficaram de fora, como toda a discussão de Exportled-growth e todo material do Banco Mundial que relaciona desempenho exportador à desempenho econômico. A explicação para isso é que esses são materiais muito mais empíricos que teóricos. Já neste ensaio procuramos relacionar os resultados de um estudo empírico específico (PRODMY, PRODXY, EXPY, IMPY) a modelos de crescimento econômico. Também ficaram de fora todos os modelos de rent seeking actions pois os dados em nada contribuiriam para o esclarecimento desse canal. Mesmo assim, algumas análises pertinentes devem ter fugido do escopo do trabalho, entretanto, se acredita que o trabalho teve algum sucesso em mapear os principais canais de conexão entre setor externo e desempenho econômico.
} 
na visão estruturalista e no Modelo de Restrição Externa para explicar a competitividade externa dos países na década de 2000. O Ensaio III mostra como a competitividade externa é internalizada, surtindo seu efeito nas variáveis macroeconômicas internas e no crescimento do PIB, em um modelo de crescimento Kaldoriano para o Brasil nos anos 2000. 


\section{Ensaio II: A restrição externa e o desempenho das economias nos anos 2000 - uma análise em painel de dados}

\subsection{Introdução}

O ensaio anterior desenvolveu um estudo empírico que permite discutir diversas teorias de crescimento e comércio externo. A conclusão principal foi que a competitividade externa é um fator fundamental para o entendimento do nível de renda per capita e da dinâmica do crescimento econômico.

Assim, neste ensaio utilizaremos um modelo que aborda esse aspecto mais diretamente para entender os diferentes desempenhos entre economias na década de 2000: o modelo de crescimento sob restrição externa. Esse modelo tem como variável principal a competitividade estrutural (não preço) para explicar os diferentes desempenhos econômicos.

Ainda que seja um modelo baseado na demanda, tem suas raízes no estruturalismo e, assim, considera a oferta em uma dimensão muito mais complexa que a simples escassez ou abundância de fatores produtivos.

A principal contribuição à literatura existente é a utilização de uma nova metodologia de teste conjunto para 137 países em uma estrutura de painel de dados, que permite discutir o desempenho diferenciado das nações nos anos 2000 com base no modelo de crescimento sob restrição externa, o que geralmente tem sido feito utilizando o instrumental de séries de tempo para alguns países específicos.

Para atingir os objetivos do ensaio, a seção 3.2 faz uma recuperação do estruturalismo cepalino e suas relações com o modelo de crescimento sob restrição externa; a seção 3.3 apresenta o modelo de crescimento sob restrição externa; a seção 3.4 apresenta a metodologia empírica; a 
seção 3.5 apresenta os principais resultados empíricos; e a seção 3.6 tece algumas considerações finais.

\subsection{As origens dos modelos de restrição externa e o estrutu- ralismo}

Esta seção objetiva demonstrar que no alicerce da construção dos modelos de restrição do balanço de pagamentos está exatamente a questão da competitividade externa e da posição das economias no mercado internacional, que pode ser mais vantajosa para algumas economias do que para outras. Embora grande parte desse instrumental estruturalista tenha sido desenvolvido no anos 1960 e algumas proposições sejam datadas para um período em que as economias periféricas estavam se industrializando, a ideia é mostrar que a essência da análise pode ser empregada para a década de 2000, e que é fundamental para discutir o desempenho das economias abertas.

A modelagem de crescimento sob restrição externa foi primeiramente desenvolvida pelo economista inglês Anthony Thirlwall (1979) que reconheceu que a equação fundamental de seu modelo é equivalente a uma versão dinâmica do multiplicador de comércio internacional de Harrod (1933).

Mais interessante, no âmbito deste ensaio, é mostrar sua correlação com os modelos estruturalistas desenvolvidos por Prebisch em 1949 (PREBISCH, 2000) e Seers (1962) como foi reconhecido pelo próprio Thirlwall (1983) que mostra que os modelos de desenvolvimento desigual de Prebisch (2000), Seers (1962) e Kaldor (1970), quando reduzidos à sua essência, igualmente associam diferenças entre taxas nacionais de crescimento a diferenças nas elasticidades-renda de exportações e importações, assim como os modelos de restrição externa.

Essa associação também é necessária para entender que, embora o modelo seja um modelo de restrição de demanda, ele está tratando de questões de oferta de um modo mais complexo que os modelos fundamentados na oferta, que considera a oferta apenas como uma questão de abundancia ou restrição de fatores. Segundo McCombie e Thirlwall (1994, p. 391):

Elasticidades-renda determinam a taxa de crescimento restritas pelo balanço de pagamentos, mas características da oferta de bens (como sofisticação técnica, qualidade, etc.) determinam as elasticidades-renda relativas. Nessa importante questão, existe um casamento entre demanda e oferta para explicar as diferenças comparativas do desempenho das nações. ${ }^{1}$

\footnotetext{
1 "Income elasticities determine the balance-of-payments constrained growth rate, but the supply characteristics of goods (such as their technical sophistication, quality etc.) determine relative income elasticities. In this
} 
Desta perspectiva é interessante revisitar o instrumental estruturalista e sua relação com o modelo de restrição externa.

O conceito central do estruturalismo é a heterogeneidade estrutural entre as economias, e seu objeto de estudo é a ocorrência do processo de acumulação em uma estrutura particular. Assim sendo, as raízes históricas das nações condicionaram sua participação na divisão internacional do trabalho e as características de suas estruturas produtivas. Em um primeiro estágio de difusão do progresso tecnológico, o centro era responsável pela produção de produtos industrializados, enquanto a periferia abastecia o centro com produtos primários. Segundo Tavares (2000), nessa fase "para fora" da periferia, as técnicas novas só eram aplicadas no setor exportador ou atividades ligadas à exportação, coexistindo com setores atrasados e de baixa produtividade. Isso gerou na periferia uma estrutura "especializada e heterogênea", enquanto a estrutura do centro é "diversificada e homogênea”.

A industrialização espontânea que se inicia nos anos 30 na periferia latino-americana, provocada pelo maior fechamento do novo centro dinâmico (EUA) e pela conjuntura das guerras mundiais, representa uma nova fase de difusão do progresso tecnológico. Ocorre uma transformação do desenvolvimento "para fora", baseado na expansão das exportações, em desenvolvimento "para dentro", baseado na ampliação da produção industrial. No entanto, segundo Bielschowsky (2000, p. 29) e Rodriguez (1981, p. 47), ao penetrar em uma estrutura especializada e heterogênea, durante a industrialização, ou seja, antes de completar o processo de industrialização integralmente, perduram os problemas de balanço de pagamentos e de desemprego estrutural inerentes à estrutura periférica.

O conceito de centro-periferia possui, também, uma conotação dinâmica. Além da analise estática de diferenciação de suas estruturas, o processo de desenvolvimento, quando deixado ao livre jogo das forças de mercado, conduz à desigualdade. Assim,

$$
Y r=\frac{L p^{*} P p}{L i^{*} P i}
$$

onde $L p$ é a produtividade dos produtos primários, $L i$ é a produtividade dos produtos industriais, $P p$ é o preço dos produtos primários, $P i$ é o preço dos produtos industriais e $Y r$ é a relação entre as rendas em ambas as atividades.

Ou seja, assume-se que o progresso técnico seja mais acelerado no centro e que, portanto, a relação $L p / L i$ diminua ao longo do tempo. Segundo a tese das vantagens comparativas, utilizada pela economia tradicional, a relação $P p / P i$ deve aumentar e, assim, os frutos do progresso

important respect, there can be a marrying of the demand and supply side explanations of the comparative growth performance of nations." (McCOMBIE; THIRLWALL, 1994, p. 391) 
tecnológico do centro difundem-se para a periferia. A tese da CEPAL é de que este movimento de preços em favor dos produtos primários não apenas não ocorreu como se inverteu, ou seja, ocorreu uma deterioração dos termos de intercâmbio. Vale ressaltar que a manutenção dos termos de intercâmbio já provocaria um diferencial de rendas entre centro e periferia provocada pelo diferencial de produtividades. A deterioração implica que, além de a periferia não absorver os ganhos do progresso técnico do centro, ela ainda transfere parte dos seus ganhos e, portanto, o diferencial de renda cresce além do diferencial de produtividades.

É importante ressaltar que a deterioração dos termos de intercâmbio não é uma hipótese fundamental para a ocorrência do diferencial de renda, e, sim, apenas um dos canais. O que a não comprovação empírica da deterioração dos termos de intercâmbio, pelo menos na medida esperada, implica para o modelo acima descrito é a necessidade de se encontrar outro canal de vazamento da renda dos países periféricos para os centrais que não seja via preço. É, portanto, necessário justificar a diferença entre produtos primários e industriais na promoção de crescimento para manter a recomendação de industrialização, em um cenário de relativa manutenção dos termos de intercâmbio.

No modelo de crescimento sob restrição externa, o diferencial de renda entre nações ocorre, como no modelo cepalino, em função da estrutura produtiva, ou seja, do tipo de produto que essa economia tem capacidade de produzir; mas o canal não é a deterioração dos preços e sim o ajuste via quantidades como mecanismo de satisfação do equilíbrio externo.

Uma interpretação do processo com um cenário de não ajuste via preços seria o seguinte: aumenta a renda na periferia, as importações aumentam mais que as exportações, mas o câmbio real não se desvaloriza; ou, ainda que se desvalorize, ocorre em uma dimensão relativamente reduzida. Assim, para reequilibrar o balanço de pagamentos, ou são necessárias medidas de contenção de demanda que diminuam a renda da periferia e reequilibrem o balanço de pagamentos, ou é necessário o financiamento externo, cujos condicionantes são um objeto particular de estudo.

Esta é a dinâmica descrita em um modelo de crescimento sob restrição externa . Com essa nova análise, centrada no diferencial de crescimento resultante de um diferencial de estrutura produtiva, sem passar necessariamente pela deterioração dos termos de intercâmbio, validase a necessidade da análise estruturalista da CEPAL para entender o crescimento econômico e justifica-se a sua recomendação de industrialização, só que através de outro canal. Citando McCombie e Thirlwall (1994, p. 259): 
deve ser superestimada, particularmente não nos permite inferir que movimentos inversos talvez melhorariam a situação do balanço de pagamentos, e que o foco do modelo Centro-Periferia de Prebisch é a diferença nas elasticidades renda da demanda de bens primários e industrializados que impõe restrições de balanço de pagamentos.

Assim, os modelos de restrição do balanço de pagamentos, ao explicitar uma função demanda por exportações e importações, em que variações de preços relativos afetam as quantidades demandadas, apontam que o canal de ajuste via quantidade pode ter sido significativamente mais relevante que o ajuste via preço. Na presença de perversidade nas elasticidades-renda das importações e exportações, que é fruto da estrutura de produção do país, o aumento da demanda interna vaza para o exterior via importação em uma proporção maior que o vazamento da demanda externa para o país, ocorrendo um diferencial de crescimento, mesmo com a manutenção dos termos de intercâmbio.

Não surpreendentemente, o modelo de restrição externa engloba dois pontos-chave da estratégia estruturalista ou desenvolvimentista. O primeiro aspecto crucial é que o crescimento é determinado pela posição que o país ocupa na divisão internacional do trabalho. Em outras palavras, o desempenho de uma economia depende de sua relação com os demais países. Por outro lado, apesar de considerar-se o modelo orientado pela demanda, esse também pode ser considerado estruturalista, pois a estrutura produtiva do país determina as elasticidades de importação e exportação, condicionando a posição que o país ocupa no mercado internacional e consequentemente determinando seu crescimento. A mensagem final do modelo é: se um país deseja aumentar a taxa de crescimento é necessário planejar para modificar a relação das elasticidades.

Pode-se construir um exemplo que relaciona diretamente a Lei de Thirlwall com a teoria de Prebisch, conforme fizeram McCombie e Thirlwall (1994). Suponha que a elasticidade de importação dos países desenvolvidos seja $\pi d=0,5$, que é igual à elasticidade-renda das exportações dos países subdesenvolvidos, $\epsilon s=0,5$. Por outro lado, suponha que a elasticidade de importação dos países subdesenvolvidos seja $\pi s=2,0$, que é igual a elasticidade-renda das exportações dos países desenvolvidos, $\epsilon d=2,0$. Pela Lei de Thirlwall (3.9), a taxa compatível com o equilíbrio do Balanço de Pagamentos é $y b t s=1,25 \%$ para os países subdesenvolvidos e $y b t d=5 \%$ para os países desenvolvidos. Ou seja, os países desenvolvidos devem crescer quatro vezes mais que os países subdesenvolvidos, caso seja ignorado o movimento de preços relativos. 


\subsection{Modelos de crescimento sob restrição externa}

Para investigar a questão da competitividade estrutural (não preço) dos países na década de 2000, este estudo empírico, reportado e comentado no que se segue, empregou a abordagem de crescimento econômico sob restrição externa, como já foi mencionado. Em sua formulação inicial, Thirlwall (1979) assim especifica a condição de equilíbrio externo:

$$
P_{d} X=P_{f} M E,
$$

onde $X$ é a quantidade de exportações de bens e serviços não-de-fatores, $P_{d}$ é o preço das exportações em moeda nacional, $M$ é a quantidade de importações de bens e serviços não-defatores de produção, $P_{f}$ é o preço das importações em moeda estrangeira e $E$ é a taxa de câmbio nominal. Nesta formulação inicial, portanto, o equilíbrio externo envolve somente a balança comercial. Expressando as variáveis da equação (3.1) em termos de taxa de crescimento, obtemos

$$
p_{d}+x=p_{f}+m+e
$$

onde as letras em minúsculo indicam as respectivas taxas de crescimento. Assumindo formas multiplicativas tradicionais, com elasticidades constantes, para as importações e as exportações, obtemos:

$$
\begin{aligned}
M & =a\left(\frac{P_{f} E}{P_{d}}\right)^{\psi} Y^{\pi} \\
X & =b\left(\frac{P_{d}}{P_{f} E}\right)^{\eta} Z^{\epsilon},
\end{aligned}
$$

onde $a$ e $X$ são constantes positivas, $\psi<0$ é a elasticidade-preço da demanda por importações, $\eta<0$ é a elasticidade-preço da demanda por exportações, $Y$ é a renda doméstica, $Z$ é o nível da renda mundial, $\pi$ é a elasticidade-renda da demanda por importações e $\epsilon$ é a elasticidade-renda da demanda por exportações. Colocando as variáveis das equações (3.3) e (3.4) em termos de taxa de crescimento, obtemos:

$$
\begin{gathered}
m=\psi\left(p_{f}+e-p_{d}\right)+\pi y \\
x=\eta\left(p_{d}-e-p_{f}\right)+\epsilon z .
\end{gathered}
$$

Por meio da substituição das equações (3.5) e (3.6) na equação (3.2), obtemos então a taxa de crescimento restringida pelo equilíbrio externo:

$$
y_{b p}=\frac{(1+\eta+\psi)\left(p_{d}-e-p_{f}\right)+\epsilon z}{\pi} .
$$


Nessa formulação inicial, assim como nas seguintes, Thirlwall (THIRLWALL, 1979; THIRLWALL, 1997) assume que, no longo prazo, a variação nos termos de troca, se alguma, é negligenciável. Formalmente:

$$
p_{d}=p_{f}+e
$$

Logo, a equação (3.7) reduz-se a

$$
y_{b p}=\frac{x}{\pi}
$$

posto que $x=\epsilon z$ é a taxa de crescimento das exportações. Assim sendo, $y_{b p}$ representa a taxa de crescimento do produto consistente com a satisfação da restrição relativa ao estabelecimento do equilíbrio externo, vindo a ser conhecida como Lei de Thirlwall.

Embora a Lei de Thirlwall explicasse razoavelmente bem a experiência de crescimento de países desenvolvidos, seu sucesso empírico era bem menor para países em estágio inferior de desenvolvimento. Assim, a discrepância entre a taxa de crescimento prevista pela Lei de Thirlwall e a taxa de crescimento efetiva, mais significativa para países em desenvolvimento, poderia ser explicada por variações no câmbio real ou pelos fluxos de capital. Na formulação imediatamente seguinte dessa abordagem, desenvolvida agora por Thirlwall e Hussain (1982), supõe-se a seguinte especificação para o equilíbrio externo:

$$
P_{d} X+F=P_{f} M E,
$$

onde $F$ é o valor nominal dos fluxos de capital, medidos em moeda local. Expressando as variáveis na equação (3.10) em termos de taxa de crescimento, obtemos

$$
\theta\left(p_{d}+x\right)+(1-\theta) f=p_{f}+m+e,
$$

onde as letras em minúsculo representam as taxas de crescimento correspondentes, enquanto $\theta$ e $(1-\theta)$ representam, respectivamente, as frações das exportações e dos fluxos de capital nas receitas externas totais, dadas por $P_{d} X+F$.

Voltando a assumir formas multiplicativas, com elasticidades constantes, para as importações e as exportações, como nas equações (3.5) e (3.6), obtemos as seguintes versões ampliadas da equação (3.7):

$$
y_{x}^{*}=\frac{(\psi+1)\left(p_{d}-e-p_{f}\right)+(1-\theta)\left(f-p_{d}\right)+\theta x}{\pi}
$$

e

$$
y_{z}^{*}=\frac{(\theta \eta+\psi+1)\left(p_{d}-e-p_{f}\right)+(1-\theta)\left(f-p_{d}\right)+\theta \epsilon z}{\pi} .
$$

Ou seja, as equações (3.12) e (3.13) representam taxas de crescimento do produto doméstico 
correspondentes à satisfação da restrição externa na presença de fluxos de capital. A taxa de crescimento econômico, agora, depende não apenas das elasticidades do comércio exterior e das taxas de crescimento do câmbio real e das exportações, mas também da taxa de crescimento dos fluxos reais de capitais. ${ }^{2}$

A partir dessa especificação ampliada da Lei de Thirlwall é que se seguirá o estudo empírico reportado neste trabalho.

Quando utilizamos a Lei de Thirlwall para estudar a diferença de desempenho entre economias, como neste trabalho, vale ressaltar que é interessante colocar o problema da restrição externa como uma questão de grau. Tanto países que crescem mais quanto países que crescem menos estão sujeitos à restrição do setor externo. Entretanto, essa restrição possibilitou taxas de crescimento muito maiores em alguns países do que em outros, por conta da estrutura das suas contas externas. Assim sendo, a competitividade estrutural do país, conforme refletida nas elasticidades-renda do comércio exterior, é um determinante fundamental de seu crescimento econômico relativo.

\subsection{Metodologia empírica}

Desde suas versões iniciais, a chamada Lei de Thirlwall tem sido submetida a diversos testes com vistas a uma avaliação de seu poder explicativo. McCombie (1997) apresenta um resumo de sucessivos passos e metodologias utilizadas com este propósito. Em seu trabalho original, Thirlwall (1979) usa o coeficiente de rank correlation de Spearman para testar o grau de associação entre a taxa de crescimento prevista pelo modelo e a taxa observada para um conjunto de países desenvolvidos, valendo-se de duas fontes amostrais para os períodos de 1953-76 e 1951-73. O resultado obtido por este teste não paramétrico foi uma relação positiva significativa entre as duas taxas.

Num segundo momento, um teste mais formal foi proposto por McGregor e Swales (1985), o qual regredia a taxa observada sobre a taxa teórica em uma cross-section de países. Os autores obtêm como resultado a rejeição da Lei de Thirlwall. No entanto, seus métodos eram problemáticos sob alguns aspectos, segundo McCombie (1997) — basicamente, o problema de que a taxa teórica é estocástica acarreta um problema de erro nas variáveis, e o problema do Japão como outlier, com crescimento não restrito pelo equilíbrio externo, induziu à conclusão errônea

\footnotetext{
${ }^{2}$ Embora incorpore fluxos de capital, essa versão ampliada de Thirlwall e Hussain (1982) não leva em conta o endividamento externo acumulado. Nesse sentido os trabalhos McCombie e Thirlwall (1997), em Moreno-Brid (MORENO-BRID, 1998; MORENO-BRID, 1999; MORENO-BRID, 2003), Elliot e Rhodd (1999) Barbosa-Filho (2001) contribuíram no sentido de incorporar elementos relativos ao endividamento externo.
} 
de que nenhum país desenvolvido teria tido crescimento restrito pelo equilíbrio externo. Estes problemas eram intrínsecos à estimação para dados em cross-section de países.

Assim, McCombie (1989) propõe um teste alternativo. Basicamente, o teste define a elasticidade-renda hipotética como sendo aquela que iguala a taxa de crescimento observada e a teórica, representada pela equação (3.9). Caso essa elasticidade-renda hipotética não seja estatisticamente diferente daquela estimada a partir da função demanda de importações efetiva do país, não se pode, então, refutar a hipótese de que o crescimento do país é restrito pelo equilíbrio externo.

A partir do estudo desenvolvido em McCombie (1989), a grande maioria das aplicações empíricas de modelos de crescimento sob restrição externa à Thirlwall passou a empregar o instrumental econométrico de séries de tempo para estimação das elasticidades por país. As evidências encontradas em uma série de estudos parecem validar a existência da restrição externa para uma amostra significativa de países em diversos períodos. Entre eles podem ser citados os trabalhos de Atesoglu (ATESOGLU, 1993; ATESOGLU, 1995) para os EUA; Christopoulos (2003), para um conjunto de sete países desenvolvidos (Austrália, Alemanha, Itália, França, Holanda, Reino Unido e USA); Hussain (1999), em seu estudo para os países Africanos; Ansari e Xi (2000), para os países do Leste Asiático; Holland, Vieira e Canuto (2004) e Pacheco-Lopez e Thirlwall (2006) para a América Latina; Razmi (2005) para a Índia, além de diversos outros estudos para determinados países em particular. Note-se que os períodos de análise e a versão do modelo de restrição externa diferem entre os estudos; assim, embora todos de alguma forma validem a Lei de Thirlwall, uma associação comparativa entre os resultados fica comprometida.

O presente artigo, por seu turno, recupera a ideia de teste do crescimento econômico sob restrição externa para um conjunto de países. De forma diferenciada, porém, este artigo propõe uma outra metodologia de teste desta abordagem ao crescimento, utilizando, para tanto, os estimadores de efeito fixo e efeito aleatório para dados em painel e, assim, não incorrendo nos principais problemas colocados por McCombie (1997).

Parte-se da especificação de um modelo ampliado que contempla a variabilidade dos termos de troca e da taxa de crescimento dos fluxos de capital, de acordo com a equação (3.12). Dividindo-se a equação (3.12) por $x$, obtemos

$$
\frac{y_{x}^{*}}{x}=\frac{(\psi+1)}{\pi} \frac{\left(p_{d}-e-p_{f}\right)}{x}+\frac{(1-\theta)}{\pi} \frac{\left(f-p_{d}\right)}{x}+C_{i}
$$

onde o termo aleatório $C_{i}=\theta / \pi$ pode ser interpretado como o efeito específico de cada país, invariante no tempo, em um painel de dados. Ou seja, torna-se possível estimar uma regressão na qual $y_{x}^{*} / x$ é a variável dependente, enquanto $\left(p_{d}-e-p_{f}\right) / x$ e $\left(f-p_{d}\right) / x$ são regressores, 
considerando-se o efeito específico de cada país, $C_{i}{ }^{3}$ Quando existe efeito específico, por sua vez, a maneira correta de estimação consistente e eficiente é através dos estimadores de Efeito Fixo ou Efeito Aleatório. ${ }^{4}$

Note-se que a estimação em um Painel de Dados torna possível a estimação do modelo para curtos períodos de tempo, como a década de 2000, já que não é necessário um número mínimo de observações em séries temporais e sim um número grande de países. Desta forma, essa metodologia de teste libertaria o modelo de ser apenas testado para longas periodicidades, sujeito a quebras estruturais ao longo do período, o que seria uma grande vantagem do método de estimação.

Entretanto, a teoria impõe suas restrições já que o modelo é claramente de longo prazo; ou seja, é apenas no longo prazo que o equilíbrio das contas externas, tal como explicitado pela sua competitividade estrutural relativa (elasticidade-renda das importações e elasticidade-renda das exportações), se coloca como a restrição relevante e que deve ser respeitada. No curto prazo a economia pode utilizar estoque de reservas, fluxo capital e cambio real para fechar suas contas com o exterior.

Ainda assim, pode-se questionar como atuou a restrição externa nos anos 2000 (2000-2008) e, para melhor elucidar os resultados para a década, pode-se compará-lo com um período mais extenso (1980-2004) agrupados em médias de cinco anos (1980, 1985, 1990, 1995 e 2000). ${ }^{5}$ Este experimento foi conduzido para os mesmos 143 países contemplados no Ensaio anterior, mas a não existência de todos os dados reduziu o conjunto para 137 países. Todos os dados anuais foram extraídos do World Development Indicators (WDI).

\subsection{Resultados empíricos}

\subsubsection{Estimação do modelo}

Estimou-se a equação (3.15) para o período 2000-2008 e 1980-2004:

$$
\frac{y_{x}^{*}}{x}=\frac{(\psi+1)}{\pi} \frac{\left(p_{d}-e-p_{f}\right)}{x}+\frac{(1-\theta)}{\pi} \frac{\left(f-p_{d}\right)}{x}+C_{i}
$$

\footnotetext{
${ }^{3}$ Note-se que a equação é Intrinsecamente Linear, ou seja, é possível a estimação como um Modelo Linear, sendo possível posteriormente recuperar os parâmetros originais, já que existe o mesmo número de equações e parâmetros: $\alpha_{1}=(\phi+1) / \pi$ e $\alpha_{2}=(1-\theta) / \pi$ (perfeitamente identificadas), lembrando que $\theta$ não é um parâmetro e sim um valor definido. Para maiores esclarecimentos consultar Greene (2008).

${ }^{4}$ Uma síntese teórica da estimação por Efeito Fixo e Efeito Aleatório, assim como o teste de Hausman para distinguir os modelos, é apresentada no Anexo E.

${ }^{5}$ Método equivalente ao utilizado por Islam (1995). Considera-se a média a cada cinco anos com o objetivo de diminuir os possíveis problemas de não estacionariedade das séries.
} 
em que $y_{x}^{*} / x$ é a variável dependente, enquanto $\left(p_{d}-e-p_{f}\right) / x$ e $\left(f-p_{d}\right) / x$ são regressores, e o termo $C_{i}=\theta / \pi$ é considerado o efeito específico de cada país.

Primeiramente é necessário saber se o melhor estimador é o estimador de Efeito Fixo ou Efeito Aleatório. Para isso utilizaremos o teste de Hausman para ambos os períodos. Caso haja uma correlação entre os regressores, ou seja, Câmbio e Capital e o termo aleatório, que no âmbito deste modelo contempla a elasticidade-renda das importações, o efeito fixo será o melhor estimador. Caso essa correlação não exista, o Efeito Aleatório será o melhor estimador.

Em ambos os casos o teste de Hausman, reportado no Anexo F, aponta para o Efeito Fixo como melhor estimador. Isso nos remete a duas análises importantes para este ensaio. A primeira é que o estimador de Efeito Fixo em um painel de dados é equivalente à estimação de uma regressão comum com variáveis dummies para país, o que nos permitirá recuperar a elasticidaderenda $\pi$ por país e, assim, comparar com o nível de renda e crescimento.

Além disso, o fato de o resultado do teste de Hausman ter apontado o estimador de efeito fixo como melhor estimador indica a existência de endogeneidade; ou seja, existe uma correlação entre as variáveis explicativas e o termo aleatório. Emerge, assim, um resultado interessante: embora a elasticidade-renda das importações seja considerada exógena no modelo, ela está correlacionada com variações no fluxo de capitais e com a taxa de câmbio real. Vale dizer, ainda que não seja possível utilizar o fluxo de capitais para equilibrar o balanço de pagamentos no longo prazo, seu ingresso, bem como a manutenção de taxas de câmbio real depreciadas, permitiria, em tese, alterar o nível da elasticidade-renda das importações e, com isso, aliviar a restrição externa. Assim é possível concluir que uma desvalorização cambial real ou uma entrada de capitais pode vir a afetar o nível da elasticidade-renda das importações.

Tabela 3.1: Resultados da estimação 2000-2008.

\begin{tabular}{rrr}
\hline \multicolumn{3}{c}{ Variável dependente: (taxa de crescimento) $\div$ (exportações) } \\
\hline \hline & Coeficiente & Probabilidade T valor \\
\hline (Termos de troca) $\div$ (Exportações) & 0,2763293 & 0,0000 \\
(Fluxo de capitais) $\div$ (Exportações) & 0,5199715 & 0,0000 \\
\hline
\end{tabular}

Note-se que neste período relativamente curto, entre 2000 e 2008, os termos de troca e o fluxo de capitais são variáveis relevantes do modelo. Dado o resultado de correlação entre essas variáveis e a elasticidade-renda das importações, há indicações que essas variáveis podem estar sendo usadas não apenas para equilibrar o balanço de pagamentos mas também para transformar as elasticidades. Ou seja, não é porque a restrição do balanço de pagamentos e a competitividade estrutural é a restrição inegável no longo prazo que os países ficam passivos esperando o dia em que se confrontarão com ela. Pelo contrário, torná-la menos perversa deve ser o objetivo 
de política econômica e os resultados do período de 2000-2008 comprovam que efetivamente foi um objetivo, assim como os exemplos da China e Índia que extensivamente usaram a desvalorização de sua moeda e o enorme fluxo de capitais para transformar sua estrutura produtiva e modificarem sua inserção no mercado internacional.

Tabela 3.2: Resultados da estimação 1980-2004.

\begin{tabular}{lrr}
\hline \multicolumn{3}{c}{ Variável dependente: (taxa de crescimento) $\div$ (exportações) } \\
\hline \hline & Coeficiente & Probabilidade T valor \\
\hline (Termos de troca) $\div$ (Exportações) & 0,9058115 & 0,0000 \\
(Fluxo de capitais) $\div$ (Exportações) & 0,0298267 & 0,1210 \\
\hline
\end{tabular}

Os resultados para um período mais longo, de 1980 a 2004, mostram que os termos de troca continuam sendo significantes na obtenção do equilíbrio de longo prazo, mas o fluxo de capitais perde sua significância. Este resultado confirma a intuição de que o fluxo de capital, tal como colocado pelo modelo, é uma variável cíclica de curto prazo e, por si só, não pode ser usada para equilibrar o balanço de pagamentos em um período extenso de tempo.

\subsubsection{Estimação das elasticidades-renda das importações}

A contribuição mais relevante deste artigo para a literatura sobre crescimento sob restrição externa à Thirlwall é a estimação da elasticidade-renda das importações através de uma estrutura de dados em painel. Afinal, podemos estimar a elasticidade-renda das importações com o cálculo de $C_{i}=\theta / \pi$, calculadas através de variáveis dummies de país, o que é equivalente à estimação de efeito fixo. A Tabela 3.3 mostra a elasticidade de importação $(\pi)$ estimada por país para o período $2000-2008 .^{6}$

Os figuras 3.1 e 3.2 apresentam um resultado esperado: países mais ricos têm uma elasticidaderenda das importações menor. Ou seja, a ideia é que o nível de produto atual foi resultado de uma taxa de crescimento elevada, possibilitada ou por uma elasticidade-renda das importações menor, ou por um crescimento das exportações maior. Esse resultado vale tanto quando analisamos um período mais curto (2000-2008), quanto quando analisamos um período mais longo (1980-2004), uma vez que o nível atual de renda em dado instante do tempo é um acumulado do crescimento de um período suficientemente longo.

Já as figuras 3.3 e 3.4 apresentam um resultado mais direto da equação fundamental do modelo de restrição externa: países com elevadas elasticidade-renda das importações devem crescer menos, para um dado comportamento das exportações. Em outras palavras, a relação entre crescimento e elasticidade-renda das importações é inversamente proporcional.

\footnotetext{
${ }^{6}$ A tabela com as elasticidades para o período 1980-2004 se encontra no Anexo G.
} 
Tabela 3.3: Elasticidade-renda das importações.

\begin{tabular}{|c|c|c|c|c|c|}
\hline \multicolumn{6}{|c|}{ Elasticidade Renda das Importaçōes } \\
\hline 1 & Albânia & 1.41 & 62 & Líbano & 1.85 \\
\hline 2 & Argentina & 2.87 & 63 & Lituânia & 0.13 \\
\hline 3 & Armênia & 1.20 & 64 & Luxemburgo & 0.52 \\
\hline 4 & Austrália & 1.37 & 65 & Macau, China, & 1.22 \\
\hline 5 & Áustria & 1.05 & 66 & Madagascar & 0.86 \\
\hline 6 & Bahrein & 0.14 & 67 & Malawi & 1.55 \\
\hline 7 & Bangladesh & 6.74 & 68 & Malásia & 1.88 \\
\hline 8 & Bielorrússia & 0.12 & 69 & Maldivas & 1.61 \\
\hline 9 & Belize & 0.11 & 70 & Mauritânia & 1.53 \\
\hline 10 & Benin & 1.52 & 71 & Maurícia & 1.17 \\
\hline 11 & Butão & 1.57 & 72 & Moldávia & 1.41 \\
\hline 12 & Bolívia & 1.22 & 73 & Mongólia & 1.44 \\
\hline 13 & Bósnia e Herzegov & 1.65 & 74 & Marrocos & 1.55 \\
\hline 14 & Brasil & 1.48 & 75 & Moçambique & 1.32 \\
\hline 15 & Burkina Faso & 2.37 & 76 & Namíbia & 1.58 \\
\hline 16 & Burundi & 1.65 & 77 & Holanda & 1.05 \\
\hline 17 & Camarões & 1.29 & 78 & Nova Zelândia & 1.28 \\
\hline 18 & Canadá, & 1.21 & 79 & Nicarágua & 1.18 \\
\hline 19 & Cabo Verde & 1.38 & 80 & Noruega & 1.21 \\
\hline 20 & Chile & 1.34 & 81 & Omã & 1.41 \\
\hline 21 & China & 1.34 & 82 & Paquistão & 1.58 \\
\hline 22 & Colômbia & 1.30 & 83 & Panamá & 1.17 \\
\hline 23 & Costa Rica & 1.52 & 84 & Paraguai & 1.46 \\
\hline 24 & Costa Marfim & 1.42 & 85 & Peru & 1.50 \\
\hline 25 & Chipre & 1.20 & 86 & Filipinas & 1.21 \\
\hline 26 & República Checa & 1.56 & 87 & Polónia & 1.04 \\
\hline 27 & Dinamarca & 1.09 & 88 & Portugal & 0.82 \\
\hline 28 & Dominica & 1.80 & 89 & Rússia & 1.46 \\
\hline 29 & Equador & 1.51 & 90 & Ruanda & 1.77 \\
\hline 30 & EI Salvador & 1.17 & 91 & Samoa & 1.36 \\
\hline 31 & Estônia & 1.62 & 92 & Senegal & 1.37 \\
\hline 32 & Etiópia & 2.21 & 93 & Seychelles & 1.22 \\
\hline 33 & Finlândia & 1.23 & 94 & Cingapura & 1.53 \\
\hline 34 & França & 1.22 & 95 & Eslovaca & 1.44 \\
\hline 35 & Gabão & 1.21 & 96 & Eslovénia & 0.92 \\
\hline 36 & Gâmbia & 1.90 & 97 & Ilhas Salomão & 1.55 \\
\hline 37 & Geórgia & 1.41 & 98 & Espanha & 1.37 \\
\hline 38 & Alemanha & 0.82 & 99 & Sri Lanka & 1.47 \\
\hline 39 & Gana & 1.78 & 100 & São Cristóvão e Névis & 1.25 \\
\hline 40 & Granada & 1.60 & 101 & St. Lucia & 1.47 \\
\hline 41 & Guiné & 1.44 & 102 & Sudão & 1.57 \\
\hline 42 & Guiné-Bissau & 1.36 & 103 & Suazilândia & 1.52 \\
\hline 43 & Guiana & 1.08 & 104 & Suécia & 1.21 \\
\hline 44 & Hong Kong & 1.48 & 105 & Suíça & 1.14 \\
\hline 45 & China & 1.43 & 106 & Síria & 1.04 \\
\hline 46 & Hungria & 1.13 & 107 & Tanzânia & 1.35 \\
\hline 47 & Islândia & 1.42 & 108 & Tailândia & 1.47 \\
\hline 48 & Índia & 2.88 & 109 & Timor-Leste & 1.07 \\
\hline 49 & Indonésia & 1.87 & 110 & Togo & 2.66 \\
\hline 50 & Iram & 1.72 & 111 & Tunísia & 1.59 \\
\hline 51 & Irlanda & 1.25 & 112 & Turquia & 1.40 \\
\hline 52 & Israel & 1.15 & 113 & Uganda & 2.07 \\
\hline 53 & Itália & 0.92 & 114 & Ucrânia & 0.23 \\
\hline 54 & Japão & 1.02 & 115 & Emirados Árabes & 1.28 \\
\hline 55 & Jordânia & 3.42 & 116 & Reino Unido & 1.58 \\
\hline 56 & Cazaquistão & 1.80 & 117 & EUA & 1.06 \\
\hline 57 & Quênia & 1.33 & 118 & Venezuela & 1.12 \\
\hline 58 & Kiribati & 1.57 & 119 & Vietnã & 1.72 \\
\hline 59 & Coréia & 1.46 & 120 & Zâmbia & 1.36 \\
\hline 60 & Quirguistão & 1.28 & 121 & Zimbábue & 1.00 \\
\hline 61 & Letônia & 2.66 & & & \\
\hline
\end{tabular}

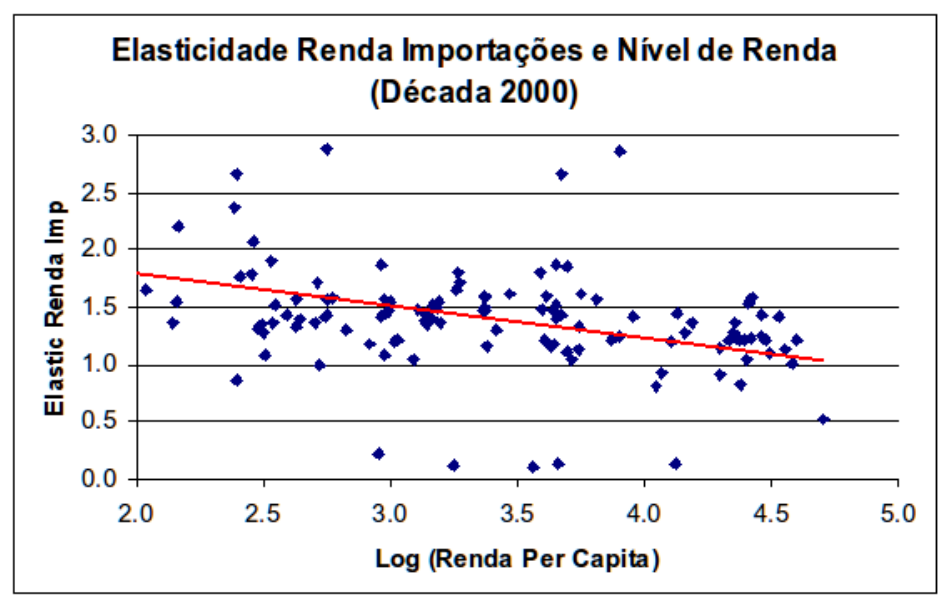

Figura 3.1: Elasticidade-renda das importações e nível de renda (2000).

Note que este resultado vale no longo prazo, quando estudamos um período mais longo (1980-2004), mas não vale para o período aqui destacado (2000-2008), que é bastante curto. 


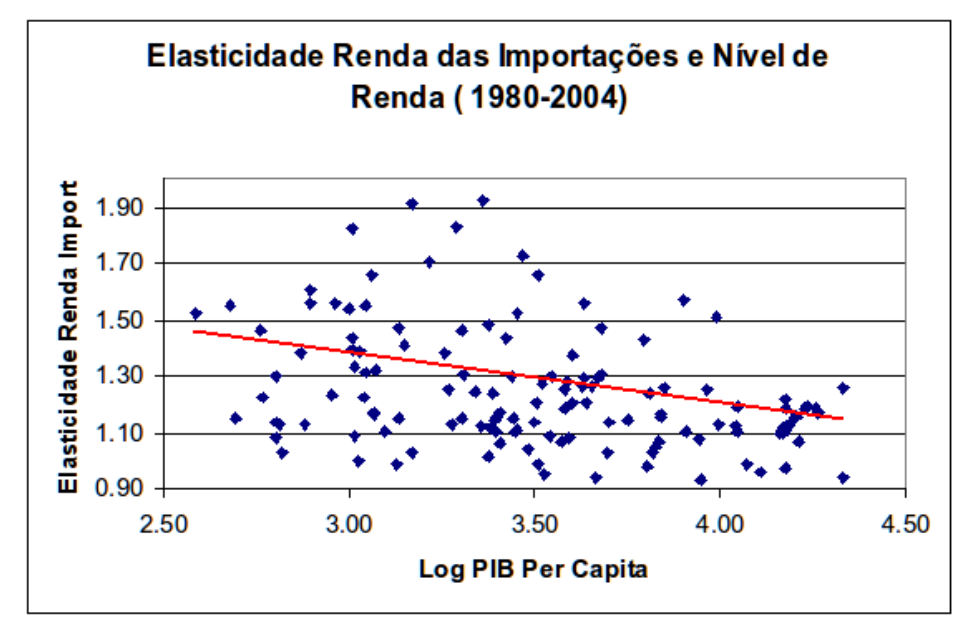

Figura 3.2: Elasticidade-renda das importações e nível de renda (1980-2004).

Isso não significa que a restrição externa não é relevante; apenas que ainda não estamos em um longo prazo suficiente para que ela se imponha como a restrição relevante e que deva ser respeitada. Isso também não significa que realizar a análise da restrição externa para um período curto como a década de 2000 não acrescente nada.

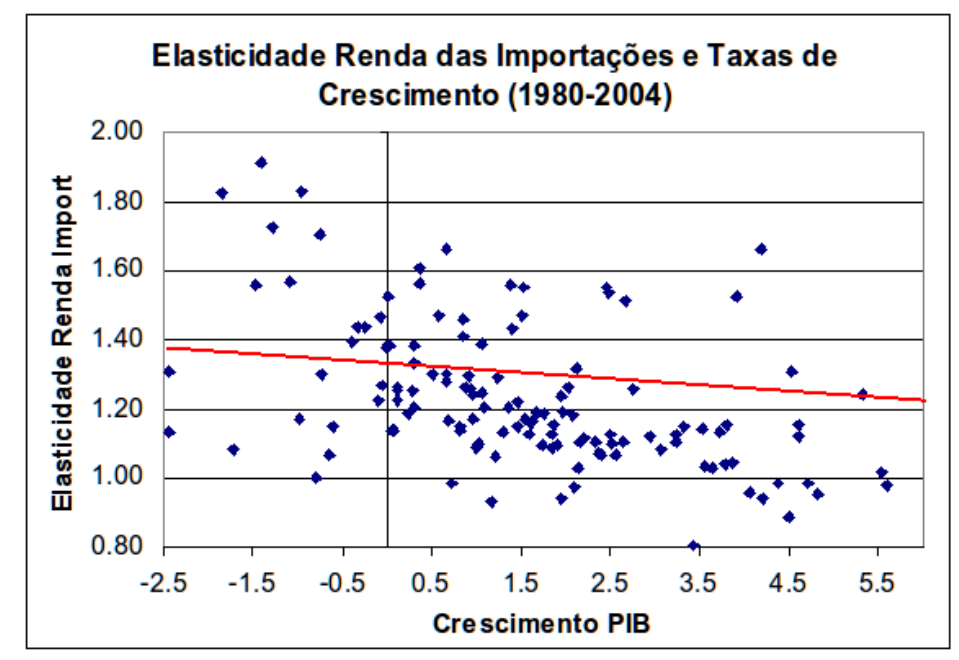

Figura 3.3: Elasticidade-renda das importações e crescimento.

Ao contrário, podemos fazer diversas análises sobre essa diferença de resultados para um período mais amplo e para a década de 2000. Primeiramente, para a década de 2000, não apenas o câmbio, mas também o fluxo de capitais se mostrou significante, o que leva as economias a se afastarem da restrição imposta por sua competitividade estrutural. De fato, conforme foi apresentado na introdução, a década de 2000 foi uma década de livre e rápida movimentação de capitais e poucos países tinham barreiras que impedissem esse movimento, o que provavelmente contribuiu, mais do que em outras décadas, para o relaxamento da restrição em alguns países.

Segundo, diferentemente da década de 1990, em que os policy-makers estavam convencidos 


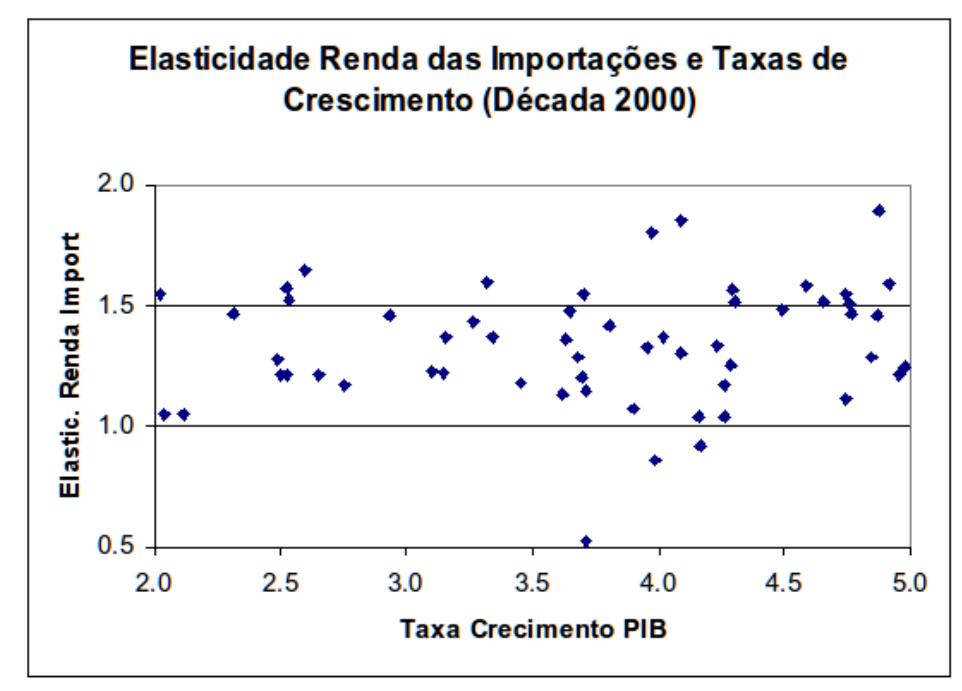

Figura 3.4: Elasticidade-renda das importações e crescimento (2000).

da teoria neoliberal e assim desejavam caminhar, no ritmo do mercado, para suas vantagens comparativas, a década de 2000 foi politicamente diferente. O papel da política econômica para transformar a restrição externa e a posição das economias no mercado internacional foi exaltado em alguns países e pode-se verificar políticas ativas neste sentido. O exemplo clássico foi a China, que sustentou uma taxa de câmbio desvalorizada com o intuito de ganhar mercados externos e alterar sua competitividade estrutural; exemplo bem sucedido como pode ser visto no na Figura 3.5. Mas a estratégia chinesa também foi aplicada em países como a Índia, a Rússia e em menor escala à Argentina, por exemplo.

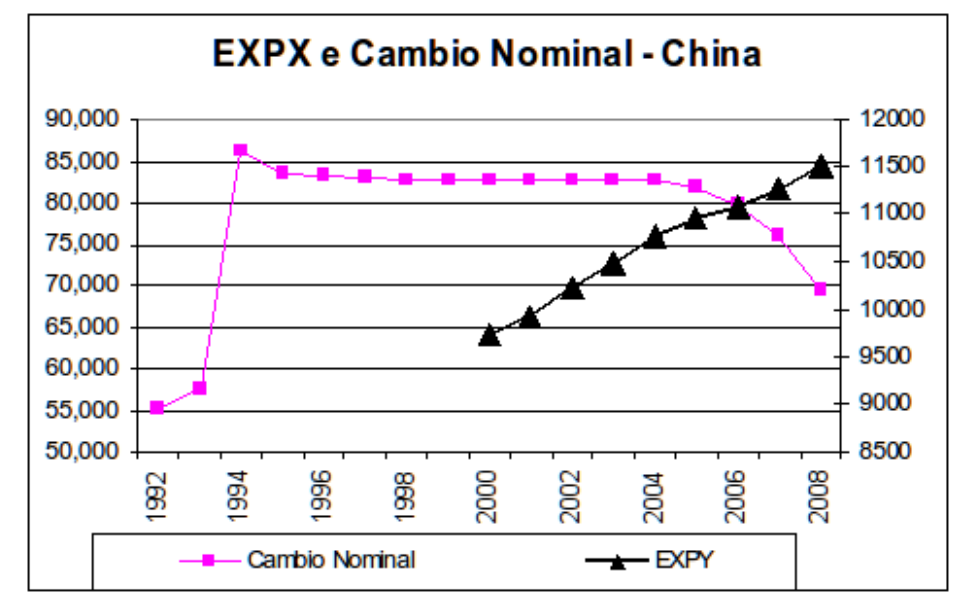

Obs: EXPY mede a qualidade da pauta exportadora conforme calculado no Ensaio I desta tese.

Figura 3.5: Qualidade das exportações e câmbio - China.

Portanto, a Figura 3.4 mostra exatamente isto: economias usando câmbio e fluxo de capitais para fecharem suas contas externas no curto prazo e, possivelmente, em alguns casos, alterando sua competitividade relativa no longo prazo. Assim, a restrição externa está em transformação e, 
por isso, não encontramos uma clara relação de causalidade invertida entre a elasticidade-renda das importações e o crescimento econômico.

\subsubsection{Elasticidade-renda e competitividade da pauta}

A metodologia proposta neste trabalho para o estudo da restrição externa nos anos 2000 difere das metodologias anteriormente empregadas. Não é uma metodologia que testa se o modelo de restrição externa é valido ou não e sim que aceita todas as confirmações da validade do modelo feita em diversos estudos e assume que o modelo tal, como na equação (3.12), é o relevante para estudar crescimento econômico. Assim as variáveis dependentes e independentes são aquelas sugeridas pelo modelo de restrição externa e, em seu resíduo, conseguimos isolar a elasticidade-renda das importações. Assim, a partir destas elasticidades analisa-se sua relação com o crescimento e a determinação da renda entre países.

Isso não é, em absoluto, diferente do que os modelos de base neoclássica fazem ao definirem as variáveis independentes como capital, capital humano, trabalho e o resíduo como produtividade total de fatores, como fez Islam (1995), entre outros autores.

Entretanto, no caso do nosso modelo, poderia questionar-se se o resíduo que foi extraído do modelo é mesmo a elasticidade-renda das importações e tem de fato alguma correlação com a competitividade importadora.

Para fazer essa análise, o gráfico da Figura 3.6 correlaciona a elasticidade-renda das importações, extraída do modelo (resíduo), e um índice que mede a qualidade da pauta importadora, IMPY, calculada no ensaio anterior a partir de mecanismos completamente diferentes.

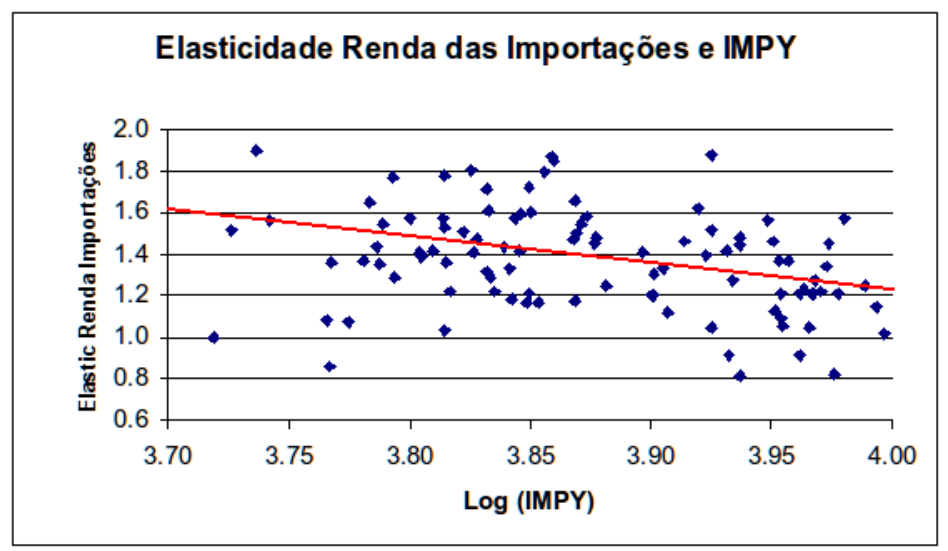

Figura 3.6: Elasticidade-renda das importações e IMPY.

O resultado foi o esperado: melhores pautas importadoras geram menores elasticidadesrenda das importações e maior crescimento. Assim, fica provada a correlação do nosso resíduo 
com a competitividade da pauta importadora, validando assim a metodologia adotada, nos termos deste modelo, uma vez que temos fortes indícios de que o resíduo extraído do nosso modelo é realmente a elasticidade-renda das importações.

Inspirado no exercício anterior, ainda que não com o objetivo de corroborar a metodologia utilizada, podemos fazer o mesmo exercício para as exportações, ou seja, verificar a correlação entre a elasticidade-renda das exportações e EXPY, calculada no ensaio anterior, e que mede a competitividade da pauta exportadora.

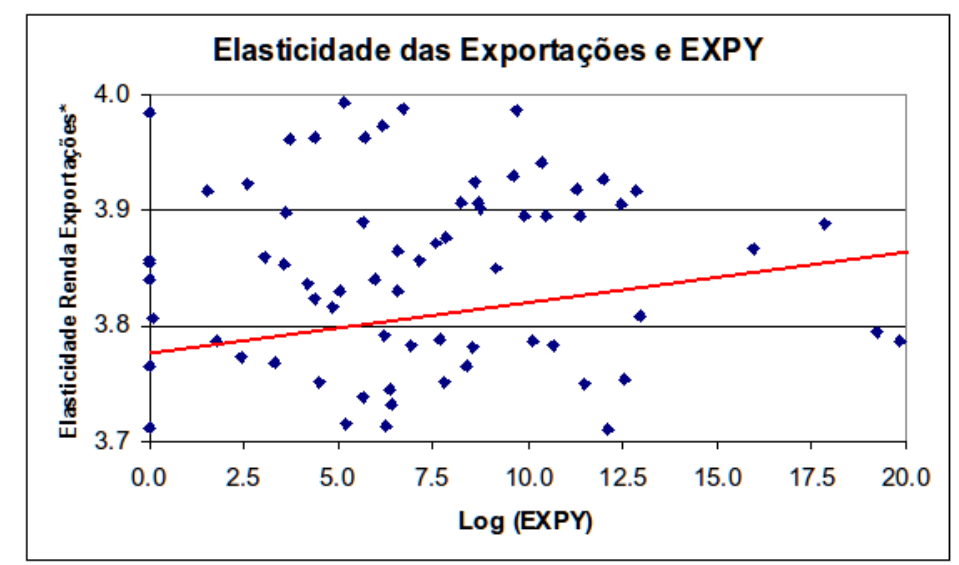

* Note que o índice não corresponde exatamente à elasticidade-renda das exportações e sim ao crescimento das exportações. Entretanto, no caso de uma comparação intrapaíses, esses índices são transformações monotônicas um do outro, já que a taxa de crescimento das exportações dividida pela taxa de crescimento da economia mundial (que é um número igual para todos os países) resultaria na elasticidade-renda das exportações.

Figura 3.7: Elasticidade-renda das exportações e EXPY.

Os resultados também atuam no sentido de confirmar a análise; ou seja, países com maior elasticidade-renda das exportações tem uma melhor pauta exportadora e, portanto, podem crescer mais. Note-se que essa associação foi feita entre dois índices calculados a partir de metodologias completamente diferentes, e ainda assim, se complementam.

\subsection{Considerações finais}

Neste ensaio, tratamos a competitividade estrutural nos termos de um modelo de crescimento com restrição externa, recuperando sua inspiração estruturalista e propondo uma nova metodologia de estimação do modelo que nos permitiu analisar o comportamento da competitividade entre países na década de 2000.

Validamos o modelo quando se trata de um horizonte de tempo mais longo, mas quando se trata da década de 2000, verificamos um movimento de transformações da restrição externa. Vimos que não apenas o câmbio, mas também o fluxo de capitais se mostrou significante, já 
que a década de 2000 foi uma década de livre e rápida movimentação de capitais, o que provavelmente contribuiu, mais que em outras décadas, para o relaxamento da restrição em alguns países. Além disso, existem evidencias de que a política econômica utilizou câmbio e fluxo de capitais para fecharem suas contas externas no curto prazo e, em alguns casos, os utilizou para alterar sua competitividade relativa no longo prazo. Assim, defende-se que a natureza da restrição externa entre países estaria em movimento na década de 2000.

Enfim, a década de 2000 foi uma década propícia para a condução de transformações estruturais, dada a grande liquidez e a percepção de que políticas ativas de relaxamento da restrição externa seriam positivas. A década terminou com uma grande crise financeira internacional, que nasceu nos países centrais, e com certeza este cenário propício à condução de transformações encerrou-se. Nos próximos anos, saberemos com mais clareza quem conduziu as transformações de maneira satisfatória ou não.

Voltando ao tema central da tese que é competitividade externa e desempenho econômico, este ensaio se limitou a discutir a questão no âmbito de um modelo de crescimento sob restrição externa. O problema é que este modelo não explicita os canais através dos quais uma maior competitividade externa levaria a um melhor desempenho econômico. Embora McCombie e Thirlwall (1994) tenham mencionado que o crescimento econômico de longo prazo sujeito à restrição externa pode implicar o seguinte círculo vicioso:

Se um país entra em dificuldades com seu balanço de pagamentos antes que a sua capacidade de crescimento a curto prazo seja alcançada, então a demanda deve ser reduzida, a oferta nunca é plenamente utilizada, o investimento é desencorajado, o progresso tecnológico é lento, o que aumenta a demanda por produtos estrangeiros, o que agrava o balanço de pagamentos ainda mais, e assim por diante. Por outro lado, um círculo vicioso é iniciado quando o país é capaz de expandir a demanda até o nível de capacidade produtiva existente, sem dificuldades no balanço de pagamentos, a pressão da demanda sobre a capacidade pode também aumentar a taxa de crescimento. ${ }^{7}$

E ainda que essa explicação seja plenamente compatível com o modelo, esse canal de transmissão não está presente na construção do modelo.

Isso nos remete ao próximo ensaio, onde desenvolveremos um modelo que explicita melhor, dentro do modelo, este ciclo virtuoso; ou seja, explora um canal através do qual uma melhora

\footnotetext{
7 “... if a country gets into balance-of-payments difficulties as it expands demand before the short-term capacity growth is reached, then demand must be curtailed; supply is never fully utilized; investment is discouraged; technological progress is slowed down, and a country's good compared with foreign goods become less desirable so worsening the balance of payments still further, and so on. A vicious circle is started. By contrast, if a country is able to expand demand up to the level of existing productive capacity, without balance-of-payments difficulties arising, the pressure of demand upon capacity may well raise the capacity growth rate." (McCOMBIE; THIRLWALL, 1994, p. 233)
} 
no setor externo pode causar uma melhora no desempenho econômico, um canal através do qual um alívio de restrições de demanda pode aliviar restrições de oferta agregada. Essa análise será feita através de um modelo Kaldoriano aplicado a um país específico, o Brasil na década de 2000.

Portanto, o primeiro ensaio usou uma metodologia para calcular um índice de competitividade externa e discutiu vários canais através dos quais competitividade externa pode afetar desempenho econômico. O segundo ensaio discutiu questões de competitividade externa e crescimento baseado em um modelo de restrição de demanda, com base fortemente estruturalista. $\mathrm{O}$ terceiro ensaio deve explicitar melhor como opera o modelo de restrição externa internamente, ou seja, como o setor externo contagia as variáveis internas e o desempenho econômico. 


\section{Ensaio III: Brasil 2003-2008 - uma análise da competitividade externa $e$ do crescimento com base em um modelo Kaldoriano}

\subsection{Introdução}

Nos dois ensaios anteriores estudamos, através de dois arcabouços diferentes, o papel da competitividade externa no desempenho econômico das nações na década de 2000. Neste ensaio faremos um estudo de caso para o Brasil na década de 2000. Isso nos permitirá dar alguma contribuição para o debate da economia brasileira no período e cumprir um papel na lógica de argumentação da tese, ou seja, explicitar como o setor externo influencia o desempenho econômico.

Após exibir um crescimento do PIB alto nas décadas de 1950, 1960 e 1970, respectivamente $7,2 \%, 6,1 \%$ e 8,8\%, a economia brasileira iniciou sua sequência de décadas perdidas. O crescimento na década de 1980 caiu para 3,0\% e foi menor ainda (1,9\%) na década de 1990. Desta perspectiva histórica, os resultados da última década parecem um pouco mais promissores: entre 2003-2008, a média da taxa de crescimento foi de 4,2\%.

Nesse contexto, este trabalho propõe-se a analisar a experiência brasileira de crescimento entre 2003-2008 ${ }^{1}$ e compará-la com a década anterior (anos 1990). O principal objetivo é obter evidências empíricas e discutir aspectos teóricos que subsidiem a análise do crescimento econômico brasileiro no período, tendo em vista a questão da competitividade externa.

Quanto à periodicidade analisada, é importante destacar que o trabalho tem como objetivo contribuir para o entendimento do período 2003-2008 em si, mas também analisará as possíveis trajetórias de longo prazo a partir da interpretação desse período. A análise baseia-se em variá-

\footnotetext{
${ }^{1}$ O período 2003-2008 foi o período compreendido entre o Governo Lula e a Crise Econômica Mundial e teve características específicas, como a melhora das contas internas e externas, que permitem tratá-lo como período específico.
} 


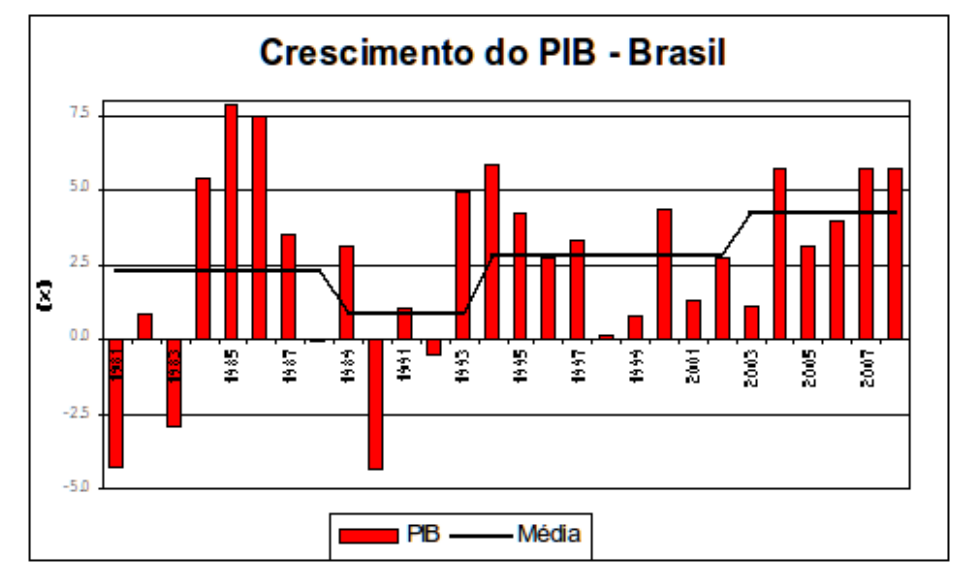

Figura 4.1: Crescimento econômico brasileiro.

veis estruturais e, portanto, não é uma análise de curto prazo, embora seja aplicada a um prazo curto: 2003-2008. Entretanto, não podemos fazer uma análise de longo prazo baseado em um período tão curto. Assim, podemos dizer que é uma análise estrutural do período que visa não apenas compreender o período em si, mas também inferir, o quanto for possível, a partir deste curto período de analise, as possíveis trajetórias de longo prazo.

Uma primeira breve caracterização inicial do período 2003-2008 sugere que, dado algum impulso inicial, a economia entrou em um ciclo virtuoso de crescimento. Considerando o tema desta tese, o argumento central será que um dos impulsos iniciais foi dado precisamente pelo setor externo, e que se espalhou pelo resto da economia em um movimento de causação cumulativa. Dessa forma, o modelo explicita os canais pelos quais uma melhora no comportamento das contas externas gerou uma melhora dos indicadores internos, entre eles o produto, considerando os elementos de oferta e demanda agregada para este período.

Apesar de o período 2003-2008 não contemplar transformações estruturais tão profundas quanto na década de 1990 (como a abertura e desestatização da economia), os dados indicam uma clara transformação positiva no comportamento do investimento, do consumo e do setor externo, em proporções maiores que nos anos 1990.

A ênfase no efeito retroalimentador e no papel ativo da demanda neste episódio de crescimento clarifica a razão de que esta interpretação não pode ser inferida a partir de modelos de crescimento baseados unicamente na oferta. Sendo assim, recorreremos a modelos de crescimento que evidenciam uma causação cumulativa entre elementos de demanda e de oferta, baseados na tradicional análise kaldoriana. Neste sentido, definiremos um modelo com estes fundamentos teóricos e prosseguiremos com um estudo empírico para a economia brasileira no período de estudo desse ensaio. Com isso pretende-se contribuir para o entendimento do funcionamento do modelo e dos fatores relevantes para explicar o crescimento econômico no 
período.

Para atingir seu objetivo, este ensaio é composto de seis seções, além desta introdução. A seção 4.2 faz uma breve caracterização histórica e econômica do Brasil entre 2003-2008, comparando este período com a década anterior. A seção 4.3 apresenta alguns dados de competitividade externa para o país neste período. A seção 4.4 faz uma pequena revisão da literatura teórica dos modelos de causação cumulativa e especifica o modelo utilizado neste estudo. A seção 4.5 apresenta a metodologia do teste empírico e os resultados desses testes para a economia brasileira. Por fim, a seção 4.6 apresenta algumas considerações finais sobre o desempenho econômico brasileiro entre 2003-2008, baseadas nos resultados obtidos.

\subsection{Caracterização da economia brasileira na década de 2000}

Após uma década de fortes crises internas, externas e políticas, na década de 1990 a economia brasileira vivenciou uma série de transformações econômicas estruturais. Os três principais pilares das reformas conduzidas no Brasil nos anos 1990 foram a abertura econômica, a privatização e a desregulamentação econômica.

A liberalização comercial teve inicio em 1987. Duas reformas, em 1988 e 1989, promoveram uma redução de tarifas médias de $51 \%$ para $35 \%$. Seguiu-se então uma redução consistente de tarifas: as alíquotas tarifárias não ponderadas, que foram em média 33,4\% entre 88-90, caíram para 17,8\% entre 91-93, 12,9\% entre 94-96, voltando a 13,9\% entre 97 e 98. Além da brusca redução na tarifa média, houve uma forte redução no desvio padrão das tarifas e as barreiras não tarifárias foram praticamente eliminadas a partir de 1990. Quanto às exportações, eliminaram-se os subsídios e reduziram-se os incentivos à exportação.

Já a redução do papel do Estado na economia ocorreu, principalmente, através de um intenso processo de privatização, que movimentou cerca de US\$100 bilhões entre 1991 e 2000 e retirou do Estado grande parte da sua função de investidor direto e mesmo de direcionador do investimento. Um outro pilar das reformas foi o processo de desregulamentação no mercado interno e externo. A primeira iniciativa, em março de 1990, revogou 113.752 decretos presidenciais dos 123.370 existentes. No setor externo foram revogados o monopólio do governo sobre a exportação de café, açúcar e importação de trigo, a exigência de licenças de importação e exportação, e ocorreu a liberalização da conta de capital do balanço de pagamentos. Nesta direção, foram anuladas várias medidas como o fim do monopólio do governo no setor de infra-estrutura e dos controles de preços em diversos setores não-comerciais, como os de aviação comercial, portos e rodovias. 
Na condução da política econômica, deu-se grande importância ao processo de estabilização, uma vez que se considerou essencial a estabilidade do sistema de preços para fundamentar as decisões privadas, sendo este, assim, um dos mais importantes compromissos do Estado. Dessa forma, baseadas nesse conjunto de ideias liberalizantes, as reformas dos anos 1990 redefiniram o papel do Estado e fortaleceram o mercado na alocação de recursos com o objetivo de aumentar a produtividade e a eficiência e consequentemente a taxa de crescimento.

Em termos de taxa de crescimento do produto, o resultado imediato das reformas foi bastante modesto: entre 1990-2002, a taxa de crescimento média do produto foi de 1,9\%, menor que o crescimento da década de 1980 (3\%), considerada uma década de crise.

No que se refere ao aumento da produtividade do trabalho, que seria um sintoma da almejada maior eficiência econômica, os dados realmente mostram uma melhora significativa (Figura 4.2). ${ }^{2}$ Entretanto, a parte mais significativa desse aumento deveu-se à redução do número de empregados, explicada pela reestruturação das antigas estatais, pelo processo de abertura e pelas transformações produtivas que ocorriam na década de 1990. O baixo dinamismo da produção neste período talvez seja um dos primeiros sinais da razão desse aumento da produtividade não ter trazido um maior crescimento econômico.

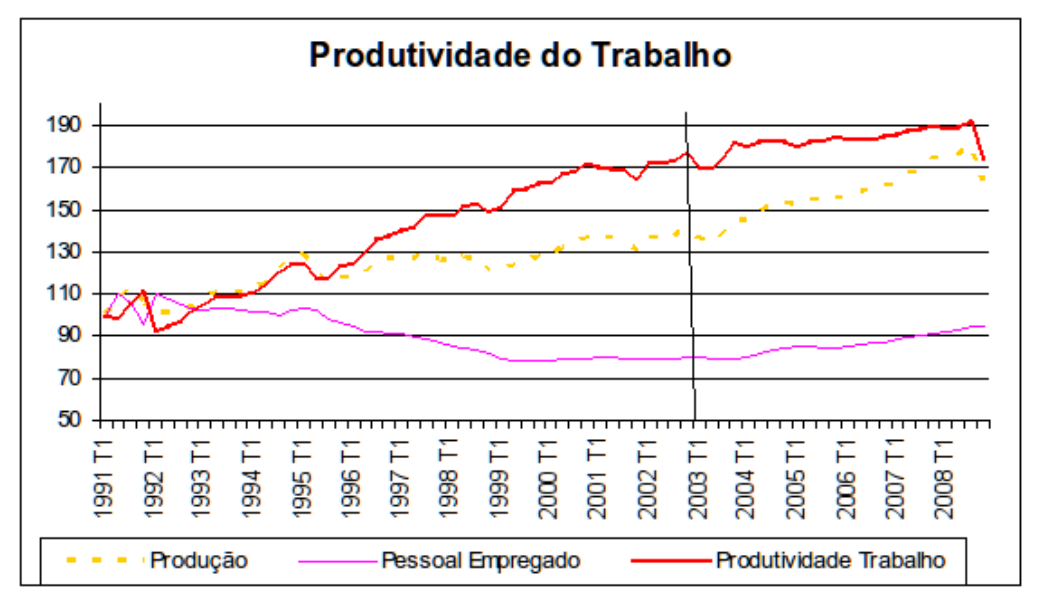

Figura 4.2: Produtividade. Fonte: Ipea.

O quadro macroeconômico do período foi extremamente conturbado. Após o programa de estabilização em 1994, o país adotou uma âncora cambial, mantendo a moeda bastante valorizada. A vulnerabilidade macroeconômica desta política, concomitante ao processo de reformas, culminou nas crises especulativas em 1995 (Crise do México), 1997 (Crise da Ásia), 1998 (Crise da Rússia) que resultaram na desvalorização do Real em 1999, e novamente em 2002, enquanto a taxa de juros oscilou bruscamente para impedir uma crise externa. Em meados do ano de 2002,

\footnotetext{
${ }^{2}$ Além dos dados apontados na Figura 4.2, um estudo mais detalhado do aumento da produtividade do trabalho pode ser encontrado em Moreira (1999).
} 
as contas fiscais e externas apontavam para um iminente default; a moeda brasileira aumentou de um patamar de $\mathrm{R}$ \$2,40/dólar para cerca de $\mathrm{R}$ \$4/dólar, e o principal título externo brasileiro caiu de 0,80 para menos de 0,50 dólares.

O resultado geral deste quadro, que se desenhou entre 1991-2002, foi que, ainda que as reformas lograssem aumentar a produtividade do trabalho, principalmente com a redução do pessoal empregado, verificou-se uma demanda agregada comprimida pela política macroeconômica: o consumo e o investimento cresceram a taxas bastante modestas e a deterioração do setor externo, como resultado tanto da abertura quanto da política macroeconômica, era preocupante e colocava o país em uma situação de extrema vulnerabilidade a ataques especulativos. Esses resultados podem ser visualizados na Tabela 4.2.

Passada a turbulência da mudança no quadro político, no final de 2002 e inicio de 2003, um outro cenário de crescimento econômico, com características diferentes, começa a tomar forma para a economia brasileira. Comparado a um período de mudanças estruturais tão profundas quanto os anos 1990, nos quais a tarifa média cai de 50\% para 13\% e elos fundamentais da cadeia produtiva são privatizados ou desregulamentados, o período entre 2003 e 2008 parece pouco interessante de ser estudado. Entretanto, os dados apontam que o período teve características particulares que se expressaram em um efetivo aumento da taxa de crescimento do produto de 1,9\% (média anos 1990) para 4,2\% (2003-2008).

Em termos de política macroeconômica não se verificou uma transformação brusca de política, mas, no tocante à política monetária, ainda sob o regime de metas de inflação, foi possível uma queda constante dos juros — ainda que tenham permanecido em patamares altos — com um controle inflacionário (Figura 4.3). Já do ponto de vista fiscal, o aumento do produto sob uma alíquota tributária alta permitiu uma situação mais folgada nos gastos públicos concomitante com uma melhora dos resultados fiscais (Tabela 4.1).

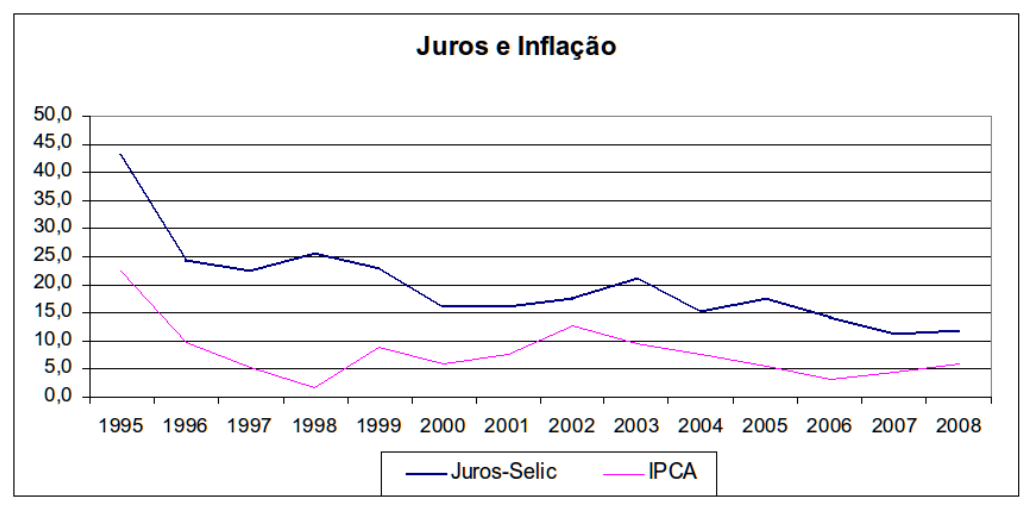

Figura 4.3: Política Monetária. Fonte: Ipea.

Quanto às políticas públicas do período, três merecem destaque. As duas primeiras são a 
Bolsa Família (transferência de renda a população de baixa renda) e a elevação real do salário mínimo. Estas duas políticas contribuíram para uma elevação dos rendimentos, uma melhora nos indicadores de pobreza e estão relacionadas a transformações importantes no mercado de trabalho, efeitos que podem ter tido consequências no comportamento do consumo e que podem, conjuntamente com o setor externo, serem alguns dos impulsos iniciais do circulo virtuoso. A terceira política é o PAC — Programa de Aceleração do Crescimento - que é um programa de investimentos públicos e pode ter tido alguma contribuição, ainda que modesta, no crescimento do investimento.

De qualquer forma, os dados mostram uma recuperação consistente do consumo e do investimento interno no período, conforme pode-se ver na Figura 4.4. Uma primeira visualização das séries de consumo, investimento e renda já indica ter havido uma transformação positiva no comportamento das séries entre 2003-2008.

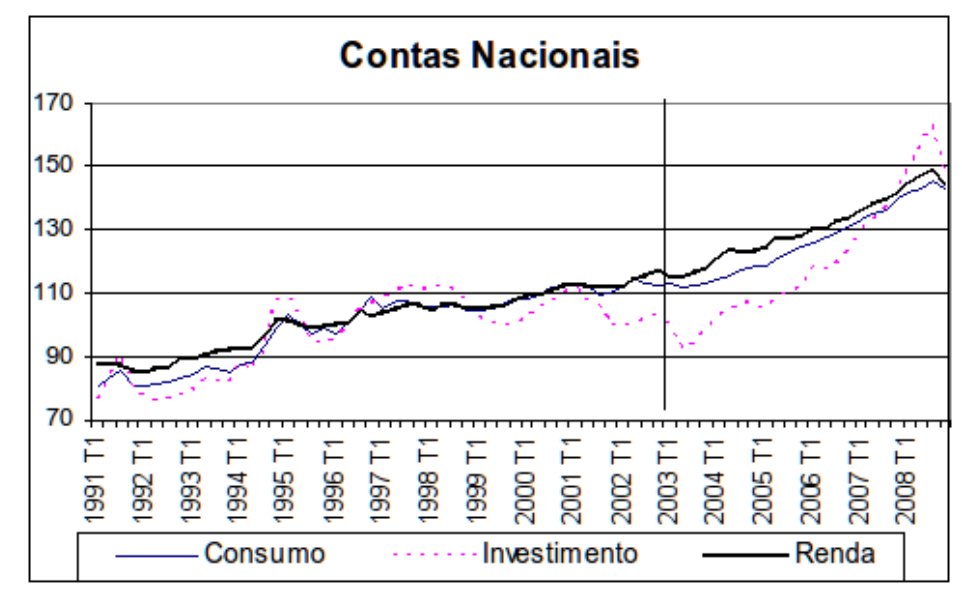

Figura 4.4: Contas Nacionais. Fonte: Ipea.

A inversão mais abrupta está correlacionada ao setor externo: o país saiu de um déficit em

Tabela 4.1: Resultados Fiscais. Fonte: elaboração própria/Ipea.

\begin{tabular}{|c|c|c|c|c|}
\hline \multicolumn{5}{|c|}{ Resultados \% PIB. } \\
\hline \hline & $\begin{array}{c}\text { NFSP } \\
\text { Nominal } \\
\text { Gov. Federal }\end{array}$ & $\begin{array}{c}\text { NFSP } \\
\text { Primário } \\
\text { Gov. Federal }\end{array}$ & $\begin{array}{c}\text { Dívida } \\
\text { Total } \\
\text { Setor Público }\end{array}$ & $\begin{array}{c}\text { Dívida } \\
\text { Externa } \\
\text { Setor Público }\end{array}$ \\
\hline $\mathbf{1 9 9 9}$ & 6,9 & $-2,4$ & 45,5 & 9,9 \\
$\mathbf{2 0 0 0}$ & 3,1 & $-1,9$ & 45,5 & 9,2 \\
$\mathbf{2 0 0 1}$ & 3,4 & $-1,7$ & 47,7 & 9,5 \\
$\mathbf{2 0 0 2}$ & 5,9 & $-2,2$ & 45,5 & 11,8 \\
$\mathbf{2 0 0 3}$ & 2,3 & $-2,3$ & 51,3 & 11,5 \\
$\mathbf{2 0 0 4}$ & 1,2 & $-2,7$ & 48,8 & 8,7 \\
$\mathbf{2 0 0 5}$ & 3,2 & $-2,6$ & 46,6 & 4,3 \\
$\mathbf{2 0 0 6}$ & 3,1 & $-2,2$ & 45,5 & $-0,4$ \\
$\mathbf{2 0 0 7}$ & 2,2 & $-2,3$ & 43,8 & $-7,0$ \\
$\mathbf{2 0 0 8}$ & 1,0 & $-2,5$ & 39,4 & $-10,5$ \\
\hline
\end{tabular}


conta corrente da ordem de 4\% para um superávit, e os indicadores de solvência externa acompanharam essa transformação, como pode-se ver na Tabela 4.2. Os dados de Comércio Externo indicam uma recuperação bastante significativa, tanto das exportações quanto das importações, sugerindo que, apesar das medidas de abertura terem sido tomadas nos anos 1990, em termos do coeficiente de abertura, apenas nos anos 2000 essa economia assume a forma de uma economia aberta, com capacidade não apenas importadora, mas também exportadora.

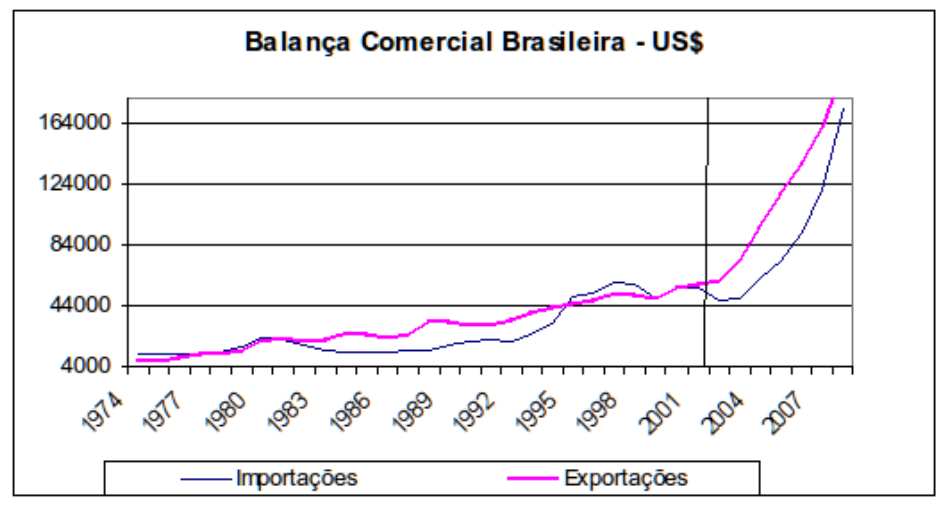

Figura 4.5: Balança Comercial. Fonte: Ipea.

Tabela 4.2: Indicadores Externos. Fonte: Elaboração própria/Ipea.

\begin{tabular}{|c|c|c|c|c|c|c|c|}
\hline & \begin{tabular}{l|} 
Conta \\
Corrente/PIB
\end{tabular} & $\begin{array}{l}\text { Divida } \\
\text { Externa/PIB }\end{array}$ & \begin{tabular}{|l|} 
Divida \\
Externa/Exp \\
(meses)
\end{tabular} & Juros/Exp & \begin{tabular}{|l|} 
Reservas \\
Internacionais \\
USS
\end{tabular} & $\begin{array}{l}\text { Reservas/lmp } \\
\text { (meses) }\end{array}$ & $\begin{array}{l}\text { Câmbio - } \\
\text { RS/USS }\end{array}$ \\
\hline $1980-92$ & $-1,5 \%$ & $37 \%$ & 46,8 & $35,2 \%$ & 9.442 & 6,6 & \\
\hline $1993-96$ & $-1,5 \%$ & $27 \%$ & 43,1 & $17,9 \%$ & 45.742 & 13,8 & \\
\hline 1997 & $-3,8 \%$ & $25 \%$ & 45,3 & $17,9 \%$ & 52.173 & 10,5 & 1,08 \\
\hline 1998 & $-4,2 \%$ & $31 \%$ & 56,7 & $22,4 \%$ & 44.556 & 9,3 & 1,16 \\
\hline 1999 & $-4,7 \%$ & $45 \%$ & 60,4 & $31,0 \%$ & 36.342 & 8,9 & 1,82 \\
\hline 2000 & $-4,0 \%$ & $39 \%$ & 51,4 & $26,6 \%$ & 33.011 & 7,1 & 1,83 \\
\hline 2001 & $-4,6 \%$ & $44 \%$ & 46,6 & $25,6 \%$ & 35.866 & 7,7 & 2,35 \\
\hline 2002 & $-1,7 \%$ & $50 \%$ & 45,3 & $21,8 \%$ & 37.823 & 9,6 & 2,92 \\
\hline 2003 & $0,8 \%$ & $46 \%$ & 38,7 & $17,8 \%$ & 49.296 & 12,2 & 3,08 \\
\hline 2004 & $1,9 \%$ & $36 \%$ & 27,4 & $13,9 \%$ & 52.935 & 10,1 & 2,93 \\
\hline 2005 & $1,8 \%$ & $24 \%$ & 19,1 & $11,4 \%$ & 53.799 & 8,8 & 2,44 \\
\hline 2006 & $1,4 \%$ & $20 \%$ & 16,8 & $8,2 \%$ & 85.800 & 11,3 & 2,18 \\
\hline 2007 & $0,1 \%$ & $18 \%$ & 18,0 & $4,5 \%$ & 142.689 & 14,2 & 1,95 \\
\hline 2008 & $-2,2 \%$ & $21 \%$ & 16,2 & $3,7 \%$ & 197.583 & 13,7 & 1,83 \\
\hline
\end{tabular}

Neste cenário, parece que, dado algum impulso inicial, a economia entrou em um ciclo virtuoso no período 2003-2008. A partir daí uma melhora da renda foi corroborada por uma política econômica menos restritiva, que melhorou o investimento, o consumo e que, por meio de relações entre oferta e demanda, provocou aumentos de produtividade que se espalharam no setor externo e interno e, assim, reiniciou-se um ciclo positivo. O pressuposto central de investigação que esta tese sugere, baseado nos ensaios anteriores, é que este impulso inicial teve origem no setor externo. Contudo, o relevante neste ensaio é investigar os mecanismos de 
transmissão que fizeram este bom comportamento do setor externo espalhar-se para todos os setores da economia, dinamizando também o mercado interno.

Assim, em geral, o período 2003-2008 foi um período de relativa prosperidade e sem maiores turbulências internas ou externas. Com base nessa experiência, e particularmente nesse efeito de retro-alimentação positiva entre as variáveis macroeconômicas, é que daremos prosseguimento à investigação teórica e empírica realizada nas seções subsequentes.

\subsection{Aspectos da competitividade externa}

Diversos estudos sobre a economia brasileira, para períodos anteriores à década de 2000 , confirmaram que a restrição do balanço de pagamentos, conforme definida por Thirlwall (1979) e algumas variações melhor especificadas no ensaio anterior, foi fundamental para a definição do produto da economia brasileira de longo prazo. Entre esses estudos, podem ser citados os de Thirlwall e Hussain (1982), Holland, Vieira e Canuto (2004), Lopez e Cruz (2000), BarbosaFilho (2001), Bértola, Higachi e Porcile (2002), Jayme (2003), Ferreira (2001), Carvalho, Lima e Santos (2008), Pacheco-Lopez e Thirlwall (2006), Vieira e Holland (2006), Nakabashi (2007), Carvalho e Lima (2009), Brito e McCombie (2009).

Entretanto, interessa-nos saber se, para o período em questão, os parâmetros estruturais dos modelos de restrição externa, ou seja, a elasticidade-renda das importações e a elasticidaderenda das exportações, tiveram uma quebra, possibilitando esse aumento de crescimento. ${ }^{3}$ Dessa forma, estimou-se, através da técnica de Mínimos Quadrados Ordinários, as funções demanda de importações (equação (4.1)) e demanda de exportações (equação (4.2)) em primeiras diferenças para o período 1932-2008: ${ }^{4}$

$$
\begin{gathered}
d(\ln m)=\psi d\left(\ln \left(p_{f}+e-p_{d}\right)\right)+\pi d(\ln y) \\
d(\ln x)=\eta d\left(\ln \left(p_{d}-e-p_{f}\right)\right)+\epsilon d(\ln z)
\end{gathered}
$$

\footnotetext{
${ }^{3}$ A Lei de Thirlwall em sua forma mais básica é $y=\epsilon z / \pi$, sendo $y$ a renda interna, $z$ a renda externa, $\epsilon$ a elasticidade-renda das exportações e $\pi$ a elasticidade-renda das importações. Assim, um aumento de $\epsilon$ aumenta o crescimento e um aumento de $\pi$ diminui o crescimento. Estes são, portanto, os principais condicionantes do crescimento interno em relação ao externo. Para maiores esclarecimentos e derivação do modelo, consulte o Ensaio II.

${ }^{4}$ Diversos estudos empíricos estimam as funções de importação e exportação em nível, utilizando-se da técnica de cointegração, já que as variáveis envolvidas são potencialmente geradas por processos estocásticos de ordem 1 . Assim, o uso de primeiras diferenças, embora resolva o problema da regressão espúria, incorreria no problema de perder a informação de longo prazo da série. No entanto, segundo McCombie (1997), é difícil perceber o porquê da perda de informação de longo prazo, ao utilizar esse modelo em primeira diferença, dado que o modelo em si é uma explicação das diferentes taxas de crescimento e não do nível. O fato de o modelo se aplicar no longo prazo está sendo considerado quando, nas estimações, se utilizam diversos anos (1932-2008). Diversos estudos empíricos têm demonstrado que a estimação em primeiras diferenças mostra-se adequada e pouco difere das estimações em nível, usando cointegração.
} 
Além da simplicidade da estimação por Mínimos Quadrados Ordinários, com este método torna-se possível introduzir mais claramente a quebra estrutural nas elasticidades-renda através de dummies de declividade. Assim, foram estimadas as funções importação e exportação por MQO em primeiras diferenças e foram testadas variáveis dummy interagindo com o coeficiente de renda interna (4.1) e externa (4.2), ou seja, variáveis dummy de declividade. Além disso, foram testadas variáveis dummy de intercepto, para os períodos em questão.

Primeiramente, faremos um modelo colocando ambas as dummies de declividade e de intercepto (Modelo I). No contexto do modelo macroeconômico utilizado, a significância da dummy de declividade implica uma mudança nos parâmetros estruturais do modelo e, portanto, provoca uma mudança na resposta das importações à renda interna, ou das exportações à renda externa, possibilitando o aumento da taxa de crescimento. Já a significância da dummy de intercepto implica um salto do nível, mas não a mudança na dinâmica da manifestação da restrição. No entanto, ainda em um modelo com dummies de intercepto e declividade, a não significância de ambas as variáveis não necessariamente implica a ausência de quebras, pois devido ao problema de multicolineariedade, os efeitos do intercepto e da declividade podem estar se confundindo. Neste caso, parte-se para um outro modelo, que testa separadamente a dummy de declividade e, posteriormente, a de intercepto (Modelo II). Caso se verifique a relevância da dummy de declividade apenas, conclui-se por uma quebra estrutural. Verificando-se a relevância apenas da dummy de intercepto, conclui-se por uma quebra de nível. Se, mesmo nos modelos que testam as duas dummies separadamente, ambas apresentarem-se não significativas, conclui-se pela não existência de quebra. Porém, ainda resta um outro caso em que, num modelo com dummies de intercepto e declividade (Modelo I), verifica-se a não significância de ambas, e no modelo que testa cada uma separadamente, ambas as variáveis apresente-se significantes. Neste caso, conclui-se pela existência da quebra, mas essa é indefinida, ou seja, não está claro se a quebra ocorreu no nível ou na resposta à variável. Neste caso, será classificada quebra indefinida.

Utilizou-se, para o teste, dados anuais da economia brasileira (Exportações, Importações, e Renda Real) entre 1932 e 2008, e um índice de crescimento da economia mundial no mesmo período. Os dados foram obtidos no ipeadata. ${ }^{5}$ Quanto à construção da série de câmbio real $\left(P_{f} E / P_{d}\right)$, utilizou-se como medida para $P_{f}$ os tradables americanos (IPA-EUA) e para $P_{d}$ os non-tradables locais (IPC-FIPE), ou seja, a medida mais tradicional de câmbio real. Seguem-se os principais resultados:

\footnotetext{
${ }^{5}$ Para dados de Balanço de Pagamentos entre 1947-2008, a fonte original é BCB; para o período 1930-1946, o IPEA compilou dados de diversos autores. Todas as séries de Balanço de Pagamentos em dólares foram deflacionadas pelo IPC americano. A série de câmbio nominal tem como fonte original BCB entre 1942 e 2008; entre 1930 e 1942, o IPEA compilou dados de diversos autores. As séries de PIB a preços constantes têm como fonte original o BNDES no período 1947-2008; no período 1930-1947 o IPEA construiu a série. A taxa de crescimento mundial tem como fonte original o World Bank (WDI).
} 
Tabela 4.3: Resultados elasticidade-renda das importações. Fonte: elaboração própria.

\begin{tabular}{|c|c|c|c|c|c|c|c|c|c|}
\hline \multirow{3}{*}{ Períodos } & \multirow[b]{2}{*}{ Dummy } & \multicolumn{3}{|c|}{ Modelo I- Declividade + Intercepto } & \multicolumn{2}{|c|}{$\begin{array}{c}\text { Modelo II } \\
\text { Declividade }\end{array}$} & \multicolumn{2}{|c|}{$\begin{array}{c}\text { Modelo II } \\
\text { Intercepto }\end{array}$} & \multirow{2}{*}{$\begin{array}{l}\text { Conclusão } \\
\text { (5\% signif.) }\end{array}$} \\
\hline & & Coeficiente & Dummy & Dummy & Coefic. & Dummy & Coefic. & Dummy & \\
\hline & Periodo & Renda & Declividade & Intercepto & Renda & Declividade & Renda & Intercepto & \\
\hline $\begin{array}{l}\text { Todo } \\
\text { Período }\end{array}$ & $1932-06$ & 2.30 & & & & & & & \\
\hline & & 0.00 & & & & & & & \\
\hline $\begin{array}{l}\text { Abertura } \\
90\end{array}$ & 1992-02 & 2.37 & 4.68 & -0.02 & 2.41 & 4.20 & 2.54 & 0.09 & Quebra \\
\hline (Prob-\%) & & 0.00 & 12.64 & 83.80 & 0.00 & 3.93 & 0.00 & 13.34 & $\begin{array}{l}\text { Estrutural } \\
\text { (aumento) }\end{array}$ \\
\hline $\begin{array}{l}\text { Governo } \\
\text { Lula }\end{array}$ & 2003-08 & 2.36 & 3.3 & 0.00 & 2.36 & 3.44 & 2.41 & 0.14 & Não \\
\hline (Prob-\%) & & 0.00 & 48.92 & 97.47 & 0.00 & 6.05 & 0.00 & 8.13 & Quebra \\
\hline
\end{tabular}

Ou seja, no caso das importações, detectamos uma quebra estrutural, um aumento na elasticidade-renda das importações no período da abertura. Isso significa, nos termos do modelo, que, tudo mais constante, o país teve que apresentar um crescimento menor no período para equilibrar suas contas externas. Já no período 2003-2008 não encontramos quebra a 5\% de significância.

No caso específico dessa quebra é natural a associação com o processo de abertura brasileiro. Ou seja, a redução das barreiras tarifárias e não tarifárias provocou um aumento das importações de bens mais elásticos. Em outras palavras, é razoável associar esse resultado a um processo interno de modificação da pauta importadora. Vejamos agora o que aconteceu com a demanda de exportações.

Tabela 4.4: Resultados elasticidade-renda das exportações. Fonte: elaboração própria.

\begin{tabular}{|c|c|c|c|c|c|c|c|c|c|}
\hline \multirow{3}{*}{ Períodos } & & \multicolumn{3}{|c|}{ Modelo Declividade + Intercepto } & \multicolumn{2}{|c|}{ Modelo Declividade } & \multicolumn{2}{|c|}{ Modelo Intercepto } & \multirow{2}{*}{$\begin{array}{c}\text { Conclusão } \\
(10 \% \text { signif.) }\end{array}$} \\
\hline & & Coeficiente & Dummy & Dummy & Coeficiente & Dummy & Coeficiente & Dummy & \\
\hline & & Renda & Declividade & Intercepto & Renda & Declividade & Renda & Intercepto & \\
\hline $\begin{array}{l}\text { Todo } \\
\text { Período }\end{array}$ & $1932-08$ & 0.92 & & & & & & & \\
\hline & & 0.00 & & & & & & & \\
\hline $\begin{array}{l}\text { Abertura } \\
90\end{array}$ & $1992-02$ & 0.85 & 2.90 & -0.06 & 0.85 & 1.34 & 0.86 & 0.04 & Não \\
\hline (Prob-\%) & & 0.00 & 70.24 & 83.49 & 0.00 & 31.36 & 0.00 & 33.97 & Quebra \\
\hline $\begin{array}{l}\text { Governo } \\
\text { Lula }\end{array}$ & 2003-07 & 0.80 & -2.24 & 0.24 & 0.80 & 3.55 & 0.79 & 0.15 & Quebra \\
\hline (Prob-\%) & & 0.00 & 66.12 & 23.82 & 0.00 & 2.04 & 0.00 & 1.02 & Indefinida \\
\hline
\end{tabular}

No caso da elasticidade-renda das exportações nenhuma quebra foi encontrada para o período de abertura. Já para o Governo Lula (2003-2008) encontramos um aumento na função de exportação, que poderia significar um maior aumento do produto, nos termos do modelo apresentado. Entretanto, diferente do caso das importações no processo de abertura, no qual foi possível identificar a quebra como uma quebra no parâmetro estrutural, ou seja, na elasticidaderenda das importações, essa quebra é mais difícil de identificar. A quebra foi considerada inde- 
finida: pode ter sido estrutural, aumentando a elasticidade-renda das exportações e consequentemente aumentando a capacidade do país crescer, ou pode ser uma quebra no intercepto, o que possibilitaria um crescimento maior em um período do tempo, mas não se traduziria em uma maior capacidade de crescimento ao longo do tempo.

Da mesma forma, não é tão automática a relação entre esse resultado e o processo que a economia brasileira está vivenciando. Não podemos afirmar que foi um processo interno, no qual a pauta de exportações migrou para setores com maior elasticidade-renda, ou que foi uma transformação no mercado internacional, aumentando a elasticidade-renda dos produtos usualmente exportados pelo Brasil. Neste segundo caso, o aumento das elasticidades dos produtos exportados pode ser sazonal, como o boom no mercado de commodities, ou pode ser um aumento permanente das preferências internacionais por produtos brasileiros. Vamos então, visualizar o que ocorreu com a qualidade da pauta exportadora (EXPY) e a qualidade da pauta importadora (IMPY), conforme definidos no Ensaio I desta tese (Figuras 4.6 e 4.7). ${ }^{6}$

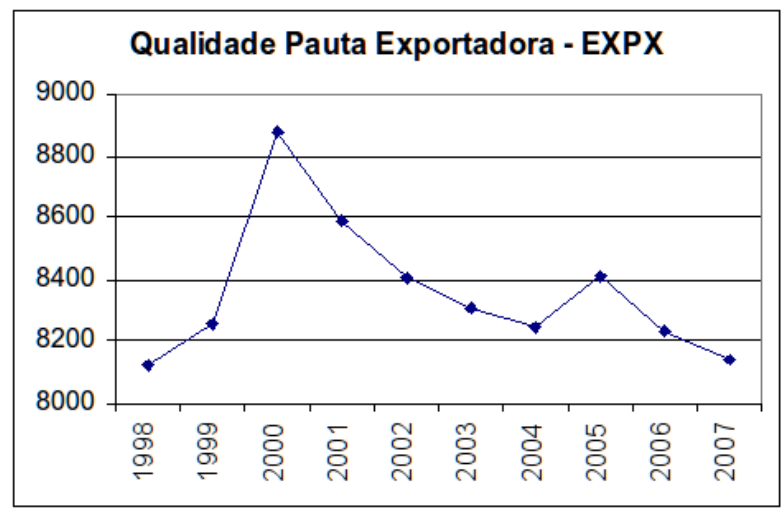

Figura 4.6: Qualidade da pauta exportadora. Fonte: elaboração própria.

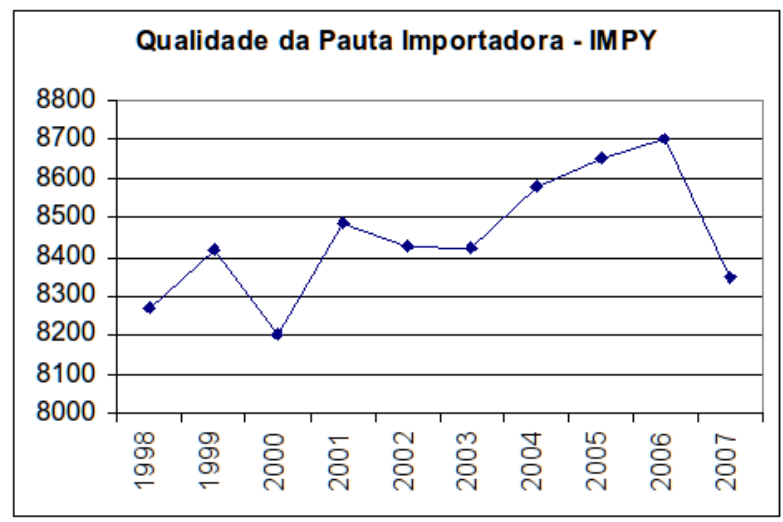

Figura 4.7: Qualidade da pauta importadora. Fonte: elaboração própria.

\footnotetext{
${ }^{6}$ Lembre-se que EXPY e IMPY foram índices calculados no Ensaio 1 e representam a renda média ponderada associada aos bens exportados ou importados por determinado país, ou seja, a qualidade da pauta exportadora e importadora.
} 
Note-se que o país experimentou uma estabilidade na qualidade da pauta de exportação, que estava, em 1997, praticamente nos mesmos níveis de 2008. Já a pauta de importação apresentou alguma melhora até 2006. Esse resultado é corroborado por Gouvêa e Lima (2010), em que as elasticidades-renda das exportações, ponderadas pela pauta, caem a partir de $1996,{ }^{7}$ conforme pode-se verificar no gráfico da Figura 4.8.

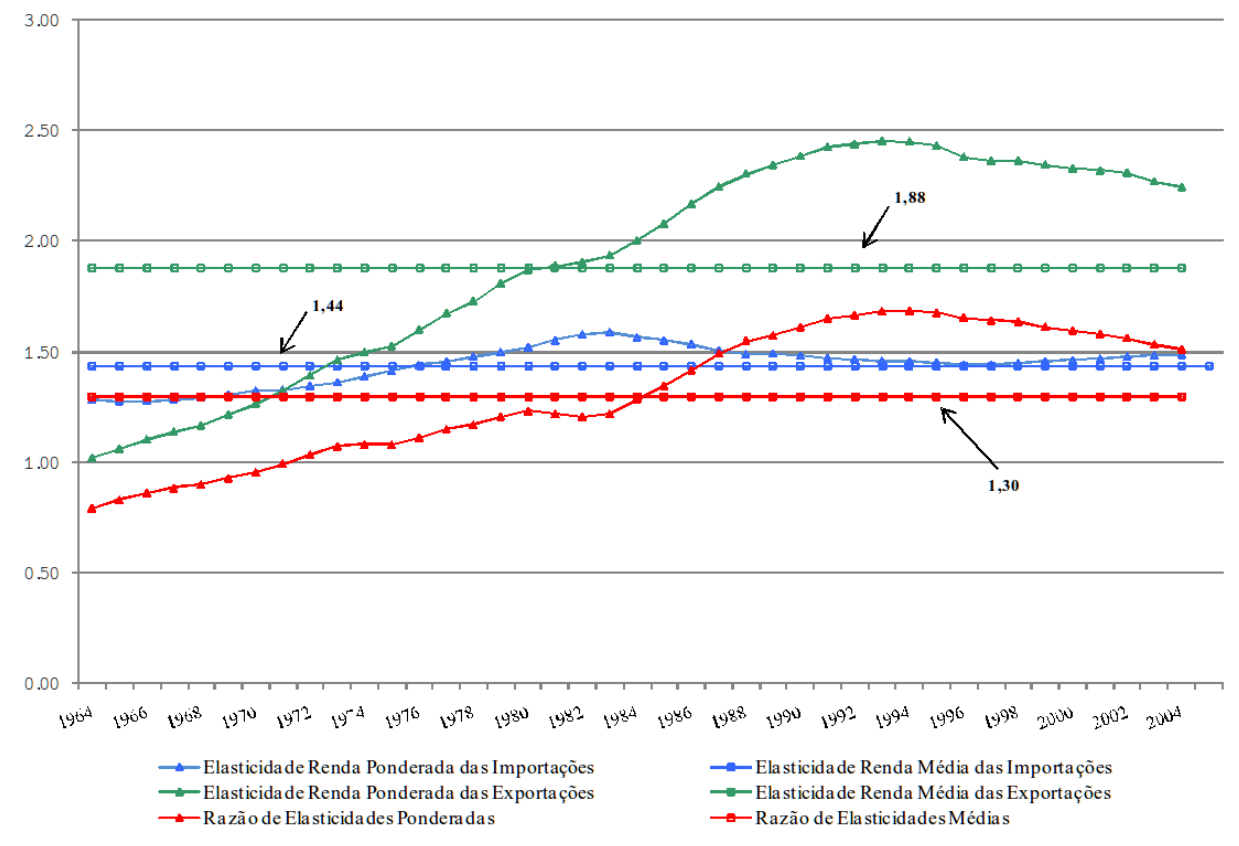

Figura 4.8: Evolução da elasticidade-renda ponderada das exportações e importações e da razão de elasticidades ponderadas — Brasil 1964-2006. Fonte: Gouvêa e Lima (2009).

Com os dados que dispomos de competitividade externa podemos afirmar que, apesar do cenário de prosperidade que se verificou na década, não houve mudanças profundas na competitividade estrutural do país que poderia conduzir a um melhor desempenho de longo prazo. O câmbio apreciado apoia essa análise, pois não foi utilizada a política cambial, como na China e Índia, para adensamento da estrutura produtiva.

O que parece estar acontecendo é que o país aproveitou o crescimento dos mercados asiáticos (Rússia, China e Índia) e aumentou as exportações para esses mercados que crescem bastante (aumentando o nível) e crescem mais que os demais países (aumento de declividade), justificando assim a quebra na elasticidade-renda das exportações tanto em nível quanto em declividade, e possibilitando, no âmbito da restrição externa, um crescimento maior. Assim, através de um câmbio valorizado foi possível o máximo efeito em moeda local dessas exportações. Parece não ter havido um movimento em direção à melhoria da pauta, principalmente expor-

\footnotetext{
${ }^{7}$ Gouvêa e Lima (2010) fazem um interessante trabalho empírico da Lei de Thirlwall Multi Setorial, considerando a composição da pauta para obtenção do equilíbrio externo, baseados no modelo teórico de Araújo e Lima (2007).
} 
tadora, ou uma melhoria estrutural. As figuras 4.9 e 4.10 ilustram a migração das exportações para países mais dinâmicos. Note-se que a China que era um parceiro comercial relativamente pequeno em 2000, torna-se, em 2008, um parceiro com a mesma relevância que a Argentina e com uma importância próxima aos EUA. Outro parceiro comercial que cresceu bastante foi a Rússia.

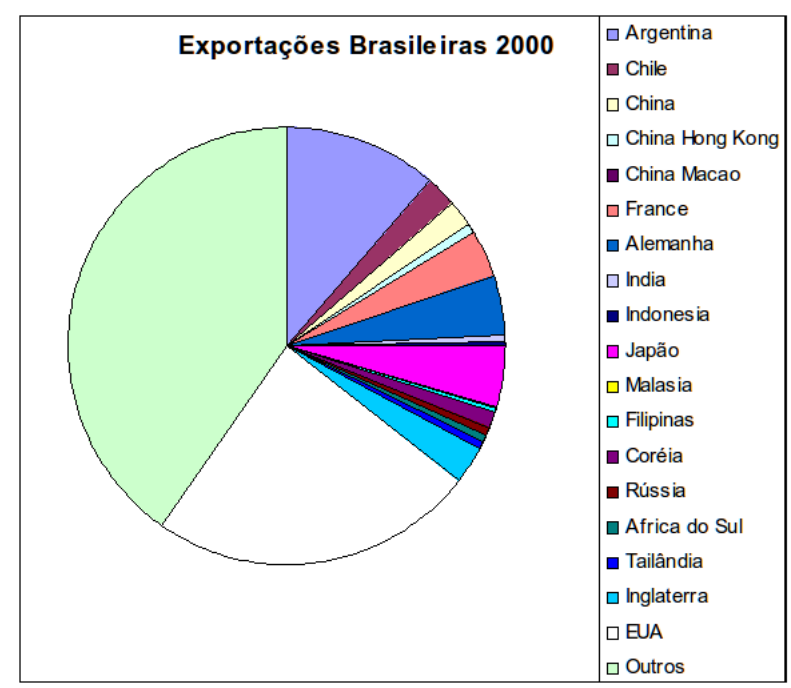

Figura 4.9: Exportações Brasileiras por país - 2000. Fonte: COMTRADE.

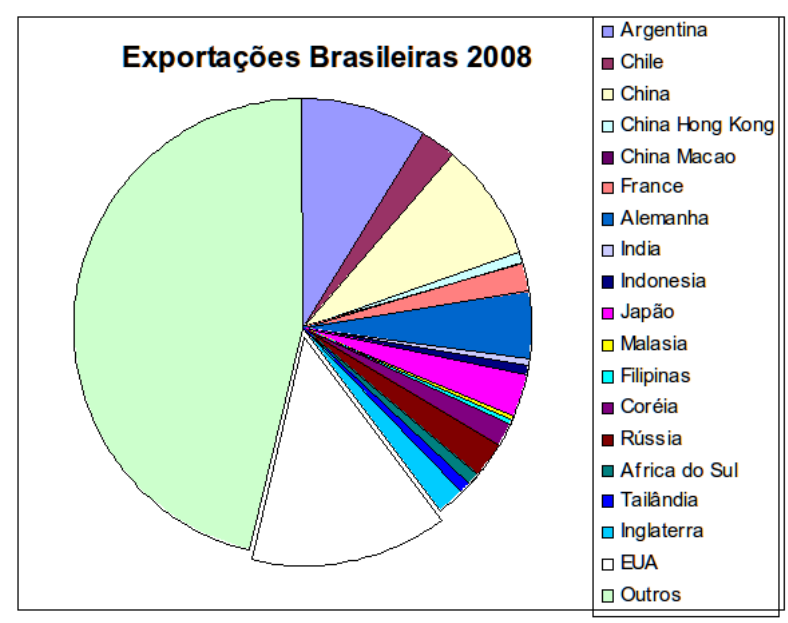

Figura 4.10: Exportações Brasileiras por País - 2008. Fonte: COMTRADE.

Essa dinâmica do mercado externo permitiu que, mesmo com manutenção estrutural da pauta exportadora, o país crescesse mais, por dois motivos: pela restrição externa menos limitadora e porque os melhores resultados externos foram os propulsores de um ciclo de causação cumulativa positiva.

Ou seja, ainda que seja um efeito temporário nas exportações, isso não impede que o país se beneficie deste efeito temporário, através de um processo de causação cumulativa, para obter 
uma dinâmica econômica positiva e duradoura, como veremos mais adiante.

\subsection{Modelos de crescimento com causação cumulativa}

A experiência brasileira no período, discutida nas seções 4.2 e 4.3 , sugere que uma interação retroalimentadora entre elementos de oferta e de demanda, assim como uma interação entre setor externo e o mercado interno, é fundamental para o entendimento do crescimento econômico da economia brasileira nesse período (2003-2008).

A abertura ocorrida na década de 1990 aumentou o acesso e reduziu o preço de novas tecnologias disponíveis para a produção, o que contribuiu para eficiência produtiva do ponto de vista da oferta; entretanto, sua contrapartida em políticas de retração da demanda agregada acabaram por comprometer não apenas o produto de curto prazo, mas o próprio produto de longo prazo. Já nos anos 2000, apesar de não ser evidente uma transformação favorável relevante dos custos de produção - como foi a abertura econômica na década anterior-, políticas de demanda mais favoráveis ao crescimento promoveram efeitos positivos sobre o produto e sobre a produtividade, favorecendo o crescimento do mercado interno e externo. Deste ponto de vista, os períodos 1990-2002 e 2003-2008 serão tratados como dois distintos episódios discretos de crescimento na linha de Setterfield e Cornwall (2002).

Dessa forma, esta interpretação do crescimento econômico brasileiro não pode ser inferida a partir de modelos de crescimento baseados unicamente na oferta. Nessa visão, a dotação de capital físico e humano, trabalho e produtividade, exogenamente determinadas, se combinam através de uma função de produção agregada e determinam o nível e a taxa de crescimento do produto do país. ${ }^{8}$ Além das críticas referentes à existência de uma função de produção agregada, ${ }^{9}$ a característica exógena dos fatores de produção impede que variações na demanda agregada tenham efeitos no produto de longo prazo na economia. Uma vez que a interpretação da história econômica no período sugere que alterações no funcionamento da demanda agregada tenham tido efeitos na dinâmica do produto, essa visão convencional não se mostra a ferramenta mais adequada para a análise que se pretende realizar. A questão fundamental da análise sugerida para a economia brasileira é permitir que o comportamento da demanda agregada tenha efeitos estruturais no produto. Com esse fim, recorremos a modelos em que a própria dinâmica da acumulação de fatores, em especial a produtividade, é determinada por elementos de oferta e de demanda.

\footnotetext{
${ }^{8}$ Visão inferida a partir de um modelo na linha de Solow (1956).

${ }^{9}$ A conhecida Crítica de Cambridge, por exemplo, liderada pelos economistas Joan Robinson e Piero Sraffa, questiona a possibilidade teórica da existência de uma função de produção agregada (HARCOURT, 1972).
} 
Evidências de que os fatores de produção sejam em parte endógenos ao comportamento do produto já foram levantados pela literatura. León-Ledesma e Thirlwall (2002), por exemplo, encontram evidências de que a taxa natural de crescimento é endogenamente determinada pelo produto corrente para 15 países da OCDE no período 1961-95. Libânio (2009) também testa a endogeneidade do produto à demanda para 12 países da América Latina, primeiro provando que choques de oferta e demanda têm efeito permanente no PIB; depois, mostrando a sensibilidade do produto natural em relação ao produto efetivo para o período 1980-2004. Já Dutt (2006) ressalta a existência de uma elasticidade da oferta em relação à demanda agregada e uma elasticidade de demanda em relação à oferta agregada, sendo ambas responsáveis pela determinação do produto. Para isso, o autor assume que a acumulação de tecnologia responde às condições no mercado de trabalho.

Com base nessa linha de argumentos e para analisar o diferencial do crescimento econômico brasileiro nos períodos 1991-2002 e 2003-2008, recorreremos, então, a modelos de crescimento que evidenciam uma causação cumulativa entre elementos de demanda e de oferta, baseados na tradicional análise kaldoriana (KALDOR, 1966; KALDOR, 1970; KALDOR, 1985; KALDOR, 1996), sobre a qual uma primeira formalização pode ser encontrada em Dixon e Thirlwall (1975) e McCombie e Thirlwall (1994, capítulos 7 e 8).

Como ressalta Setterfield (2010), para Kaldor, a interação de dupla causalidade entre oferta e demanda pode ser interpretada como um processo de causação cumulativa, onde um crescimento maior induz a retornos crescentes dinâmicos, que aumentam a competitividade e não preço das exportações e, portanto, as exportações aumentam, o que levará ao crescimento do produto. Ressalte-se que, para Kaldor, demanda é influenciada mas não determinada por condições de oferta, uma vez que sua base teórica está no principio da demanda efetiva de Keynes. Adicionalmente, as exportações têm sua importância ressaltada, pois elas são os gastos autônomos que geram divisas e, portanto, simbolizam o tamanho do mercado que a produção doméstica tem à disposição. Além disso refletem a competitividade, e consequentemente têm o papel de impedir restrições ao crescimento frutos de desequilíbrios no balanço de pagamentos.

Campo e Taylor (1998) utilizam um modelo com essas características para analisar o efeito de diferentes políticas de comércio e de diferentes regimes macroeconômicos no crescimento e no aumento de produtividade. Em um dos casos apresentados, uma política de liberalização econômica pode ter, por um lado, efeitos positivos sobre a produtividade, aumentando a eficiência dos produtos oferecidos; e por outro lado, gerar uma situação macroeconômica desfavorável via intensificação da restrição externa ou desestímulo ao investimento com capital nacional. Esta configuração de políticas levaria a uma situação tal que ocorreria aumento de produtivi- 
dade e queda do crescimento do produto, situação que pode ser comparada com os resultados da década de 1990 na economia brasileira. Note-se que o objetivo dos autores é organizar a discussão do efeito de políticas econômicas utilizando modelos com essas características e não comprovar empiricamente sua eficácia para uma experiência específica. Já este ensaio objetiva dar alguma contribuição nessa direção.

Foram Setterfield e Cornwall (2002) que efetivamente formalizaram uma versão de modelo neo-Kaldoriano que inspirará a versão adotada neste ensaio, com o objetivo de analisar dois episódios diferenciados de crescimento mundial: Idade de Ouro (1945-1973) e Pós Idade de Ouro. Os autores caracterizam o Regime de Produtividade e o Regime de Demanda, tal como será adotada neste ensaio; porém, no Regime de Demanda, os autores não discriminam funções de consumo, investimento, importações, considerando apenas dois tipos de despesas: exportações e outras despesas que não exportações. Já neste trabalho faremos alguma diferenciação entre esses gastos objetivando precisar melhor as transformações do período. Segundo a análise dos autores, o período 1945-73 foi marcado por um comportamento mais positivo, tanto do Regime de Demanda quanto do Regime de Produtividade. O Regime de Demanda foi beneficiado por medidas macroeconômicas não deflacionárias e altas taxas de acumulação de capital. Já o Regime de Produtividade foi influenciado positivamente pelas altas taxas de acumulação de capital, que possibilitaram um progresso tecnológico incorporado em capital físico. Para chegar a essa conclusão, os autores não recorrem a um teste econométrico mais formal; entretanto, sinalizam as transformações com dados empíricos, sendo que este trabalho também pretende dar algum passo adicional neste sentido.

Um modelo mais complexo, que abordou outras questões de desenvolvimento e executou um teste econométrico mais formal, foi desenvolvido por Naastepad (2006) em seu estudo sobre a economia holandesa no período 1960-2000. Usando essa linha de modelos, o autor define uma função consumo do tipo kaleckiana, distinguindo entre consumo de trabalhadores e capitalistas. Da mesma forma, a função investimento responde à lucratividade. Além de usarem a Lei de Verdoorn-Kaldor, que relaciona o crescimento da produtividade ao crescimento do produto, eles introduzem um outro efeito, fazendo a produtividade responder a salário real. Com esses ingredientes, uma economia, a depender da configuração de parâmetros, pode ser wage-led ou, em outras palavras, o impacto positivo do aumento de salário no consumo é maior que seu efeito negativo no investimento e nas exportações. Além disso, a retroalimentação causada pela especificação feita por eles, que capta o progresso tecnológico induzido por salários maiores, também é um dos canais de propagação deste efeito. Estas características complementares, derivadas de uma função consumo kaleckiana e da especificação da Lei de Verdoorn adicionada ao efeito do salário sobre produtividade, não serão consideradas neste ensaio por duas razões. 
Primeiro, não se pretende explorar, neste trabalho, o canal da distribuição funcional da renda como fomentadora do processo de causação cumulativa. Segundo, também iremos desconsiderar, neste ensaio, o canal de propagação relacionado ao progresso tecnológico como indutor de salários maiores. Entretanto, o autor desenvolveu um teste econométrico em dois estágios que inspirará o teste feito adiante. Baseado neste modelo, o autor faz uma crítica sobre a efetividade de políticas de contenção de salários para estimular produto e produtividade, utilizando a experiência holandesa.

Bezerra, Oreiro e Lemos (2008) usam um modelo com essas características retroalimentadoras para estudar os efeitos de regras de política monetária e abertura da conta capital sobre o desempenho do produto. Os autores concluem que a regra de política monetária é relevante na determinação do produto de longo prazo caso as importações reajam ao câmbio real. Para demonstrar este resultado, os autores usam simulações, mas não endereçam nenhum episódio especifico.

Setterfield (2010) baseia-se em Dixon e Thirlwall (1975) e Setterfield e Cornwall (2002) para construir um interessante modelo de crescimento endógeno baseado na teoria kaldoriana, reconciliando no âmbito dessa teoria a taxa de crescimento natural e a real. O trabalho, com diversas semelhanças com o adotado neste ensaio, é teórico e pode ser aplicado a diversos episódios discretos de crescimento, como, por exemplo, a discussão da crise financeira internacional no final da década de 2000. Dessa perspectiva, nosso trabalho é voltado para um período bastante definido da economia brasileira.

Assim, com base nesses estudos, e considerando as questões sobre economia brasileira levantadas nas seções anteriores, utilizou-se um modelo teórico que possui os seguintes fundamentos:

\subsubsection{Regime de produtividade}

O Regime de Produtividade estabelece uma relação de oferta, indicando como os ganhos de produtividade são obtidos e sua relação com o produto potencial. A base do Regime de Produtividade é a Lei de Verdoorn, que mede o impacto do produto efetivo na produtividade. $\mathrm{O}$ princípio central é que a variação da produtividade é determinada pela demanda e endógena ao processo de crescimento. A justificativa da Lei de Verdoorn pode ser a existência de retornos crescentes de escala, ou seja, o crescimento da produtividade com o crescimento do mercado. Outra justificativa seria o progresso tecnológico embutido no investimento; dessa forma o elemento Investimento da demanda agregada contribuiria para a acumulação de tecnologia. Não cabe discutir aqui mais detalhadamente os embasamentos teóricos e empíricos da Lei de Ver- 
doorn, ${ }^{10}$ mas note-se que essa relação é fundamental para que variações de demanda tenham efeito no produto e, assim, nos permita discutir os aspectos que já levantamos para a economia brasileira. Dessa forma, adotaremos a forma mais tradicional da respectiva Lei, considerando que variações de produtividade respondem a variações do produto,

$$
q=r+\alpha y,
$$

onde $q$ é a taxa de crescimento da produtividade do trabalho, $r$ representa os componentes exógenos da produtividade e $y$ é a taxa de crescimento do produto. Sendo assim, $\alpha$ é a elasticidade da produtividade em relação ao produto ou o chamado coeficiente de Verdoorn.

\subsubsection{Regime de demanda}

O Regime de Demanda especifica as relações fundamentais do comportamento da demanda agregada, assim como sua relação com a taxa de crescimento da produtividade do trabalho. As seguintes relações compõem o Regime de Demanda:

\section{Igualdade de Demanda Agregada}

$$
y=c+i+x-m
$$

onde y é a taxa de crescimento do produto, $c$ é a taxa de crescimento do consumo (privada e pública), $i$ é a taxa de crescimento do investimento (privada e pública), $x$ é a taxa de crescimento das exportações e $m$ é a taxa de crescimento das importações.

\section{Função Consumo}

$$
c=c_{0}+\lambda y
$$

A função consumo aqui adotada assume uma forma keynesiana simples, em que o crescimento do consumo $(c)$ tem um componente autônomo $\left(c_{0}\right)$ e depende da taxa de crescimento do produto corrente $(y)$, em que $\lambda$ representa a resposta de variações no consumo em relação a variações da renda. ${ }^{11}$

\footnotetext{
${ }^{10}$ Uma discussão mais detalhada na Lei de Verdoorn, assim como seus principais resultados empíricos pode ser encontrada em McCombie, Pugno e Soro (2002).

${ }^{11}$ Outra opção seria adotar uma função de consumo Kaleckiana, discriminando entre consumo de trabalhadores e capitalistas, assim como faz Naastepad (2006).
} 


\section{Função Investimento}

Utilizou-se uma função investimento com uma forma bastante simplificada, em que o investimento depende da renda (quantidade) e da taxa de juros (preço); em outras palavras, uma função investimento como em um modelo de ISLM tradicional. Como investimento é função da taxa de juros, em uma pequena economia aberta, a taxa de juros interna será a taxa de juros internacional $\left(i^{*}\right)$ mais um prêmio de risco $(\sigma)$, que assumiremos constantes e dados para o período, mais as variações esperadas da taxa de câmbio (assumiremos que a variação esperada é igual a variação real); ou seja, assumiremos um ambiente sem incertezas significativas, o que para o período parece uma hipótese razoável. Em outras palavras, usaremos uma relação de paridade da taxa de juros, fazendo com que o câmbio real tenha efeito sobre investimento através da taxa de juros:

$$
I=A B^{\theta_{0}} Y^{\theta_{1}} i^{*} \sigma\left(\frac{P d}{P f E}\right)^{\theta_{2}} .
$$

Assim, em termos de taxa de variação, tem-se

$$
i=i_{0}+\theta_{1} y+\theta_{2}\left(p_{d}+p_{f}-e\right)
$$

onde $i$ é a variação do logaritmo do investimento, $y$ é a variação do logaritmo da renda nacional e $\left(p_{f}+e-p_{d}\right)$ é a variação do logaritmo do câmbio real. $\mathrm{O}$ parâmetro $i_{0}$ é a constante e $\theta_{1}$ e $\theta_{2}$ são as respectivas elasticidades renda e câmbio do investimento. Ou seja, deriva-se que variações na taxa de câmbio real é uma das variáveis significativas na tomada da decisão do investimento, porque em uma economia aberta onde a taxa de juros é igual à internacional, o câmbio real abarca toda a perspectiva variações de rendimento ou competitividade estrutural do país.

\section{Função Exportação}

A função exportação adotada responde à taxa de câmbio real e à renda externa:

$$
X=B\left(\frac{P_{d}}{P_{f} E}\right)^{\eta} Z^{\epsilon}
$$

Em termos de taxa de variação, tem-se

$$
x t=\eta\left(p_{d}-p_{f}-e\right)+\epsilon z
$$

onde $x$ são as exportações brasileiras, $\left(p_{f}+e-p_{d}\right)$ é o câmbio real, $z$ é a renda mundial, $\eta$ é a elasticidade-preço da demanda por exportações e $\epsilon$ é a elasticidade-renda da demanda por exportações. 


\section{Função Importação}

A função importação adotada responde à taxa de câmbio real e à renda interna:

$$
M=a\left(\frac{P_{f} E}{P_{d}}\right)^{\psi} Y^{\pi} .
$$

Em termos de taxa de variação, tem-se

$$
m t=\psi\left(p_{f}+e-p_{d}\right)+\pi y,
$$

onde $m$ são as importações brasileiras, $\left(p_{f}+e-p_{d}\right)$ é o câmbio real, $y$ é a renda interna, $\psi$ é a elasticidade-preço da demanda por importações e $\pi$ é a elasticidade-renda da demanda por importações.

\section{Equação de Formação de Preços}

Foi assumida uma equação de formação de preços similar à de Setterfield e Cornwall (2002), que nos permitirá relacionar os parâmetros das demais equações de demanda à produtividade por meio da explícita relação entre $p_{d}$ e $q$ :

$$
p_{d}=(w+\tau)-q
$$

onde $p_{d}$ é a variação do preço doméstico, $w$ é a variação do salário nominal, $\tau$ é a variação da taxa de mark-up e $q$ é a taxa de crescimento da produtividade. Assumiremos que $\tau=w=0$, ou seja, não houve variações significativas na distribuição funcional da renda entre mark-ups e salários e, portanto, a equação assume a seguinte forma:

$$
p d=-q
$$

Assumindo que $e=p f$, ou seja, que as variações dos preços externos foram captadas pelo câmbio nominal, e que $\tau=w=0$, ou seja, não houve variações significativas na distribuição funcional da renda, conclui-se que a taxa de cambio real é igual a $q$, ou seja, a produtividade do país.

Substituindo as equações (4.5), (4.7), (4.9), (4.11) e (4.12) em (4.4) e resolvendo para a renda interna, obtemos

$$
y=\frac{1}{1-\lambda-\theta_{1}+\pi}\left(\left(i_{0}+c_{0}\right)+\epsilon z\right)+\frac{\theta_{2}+\eta+\varphi}{1-\lambda-\theta_{1}+\pi} q .
$$

Esta especificação enfatiza alguns aspectos e impõe algumas restrições na sua utilização 
para análise da economia brasileira no período. Em termos de restrições, para chegar na equação (4.14) acima, considerou-se duas simplificações bastante fortes que poderiam ter alguma influencia no período em questão e que não estão sendo consideradas. A primeira hipótese é que $e=p f$, ou seja, que as variações dos preços externos foram captadas pelo câmbio nominal e, portanto, as alterações de câmbio real significativas se devem a variações de preços internos (isso exclui parte da discussão sobre o papel do aumento internacional do preço de commodities, por exemplo). A segunda hipótese é que $\tau=w=0$, ou seja, que não houve variações significativas na distribuição funcional da renda entre mark-ups e salários. Com estas duas hipóteses, deriva-se que o câmbio real é igual a $q$, ou seja, câmbio real é produtividade. Outra restrição é a de que a especificação da identidade de demanda não distingue investimento e consumo privado e governamental, deixando de tratar algumas características da participação do setor público no processo de desenvolvimento. Além disso, a adoção de uma função consumo tipicamente keynesiana exclui a discussão sobre os efeitos da distribuição funcional da renda no crescimento, o que seria possibilitada pela adoção de uma função kaleckiana, por exemplo. Em outras palavras, a especificação feita pouco contribui na contabilização do crescimento devido à transformações na distribuição de renda funcional. Em relação à função investimento, permitese que câmbio real afete o investimento somente através dos juros e não diretamente por meio do estímulo ou desestímulo de importações ou exportações; exclui-se assim um canal direto de propagação entre setor externo e interno. Em relação ao regime de produtividade, note-se que se adota uma das formas mais básicas, ou a Lei de Verdoon-Kaldor original, onde a produtividade responde apenas à renda. Já Naastepad (2006), por exemplo, inclui o salário real; ou seja, este trabalho exclui o canal de propagação que salários maiores teriam como indutores de progresso tecnológico e consequentemente seus efeitos sobre o produto.

Neste ponto, a questão que se coloca é por que excluir do modelo tantos canais de propagação entre demanda e oferta, entre setor interno e externo, se é exatamente isso que se pretende analisar. A resposta é que apenas um canal de transmissão ficou aberto: a Lei Verdoon-Kaldor; ou seja, é apenas necessário que o leitor acredite que produtividade dependa do produto real, seja porque existem retornos crescentes de escala, seja porque existe progresso tecnológico embutido no investimento, ou por qualquer outra razão. Apenas este canal nos entrega grande parte do efeito retroalimentador que apuramos para esse período.

Por outro lado, a especificação acima permite discutir uma série de aspectos que são considerados relevantes para a economia brasileira. A especificação de uma função consumo e de uma função investimento diferenciadas abre a possibilidade para que alterações nessas variáveis expliquem parte do comportamento do produto. Segundo, a especificação clara das funções de importação e exportação inova em relação ao modelo de Setterfield e Cornwall (2002). 
Dessa forma, podemos simplificar o regime de demanda, a partir de (4.14), na seguinte equação:

$$
y=\beta A+\beta \phi q,
$$

onde

$$
\begin{aligned}
& \beta=1 /\left(1-\lambda-\theta_{1}+\pi\right), \\
& A=\left(\left(i_{0}+c_{0}\right)+\epsilon z\right), \\
& \phi=\theta_{2}+\eta+\varphi .
\end{aligned}
$$

\subsubsection{Estabilidade do equilíbrio}

Portanto, as duas equações estruturais do modelo foram definidas:

Regime de Produtividade (RP): $q=r+\alpha y$ (4.3).

Regime de Demanda (RD): $y=\beta A+\beta \phi q$ (4.15).

O gráfico na Figura 4.11 permite-nos visualizar a operação dos dois regimes.

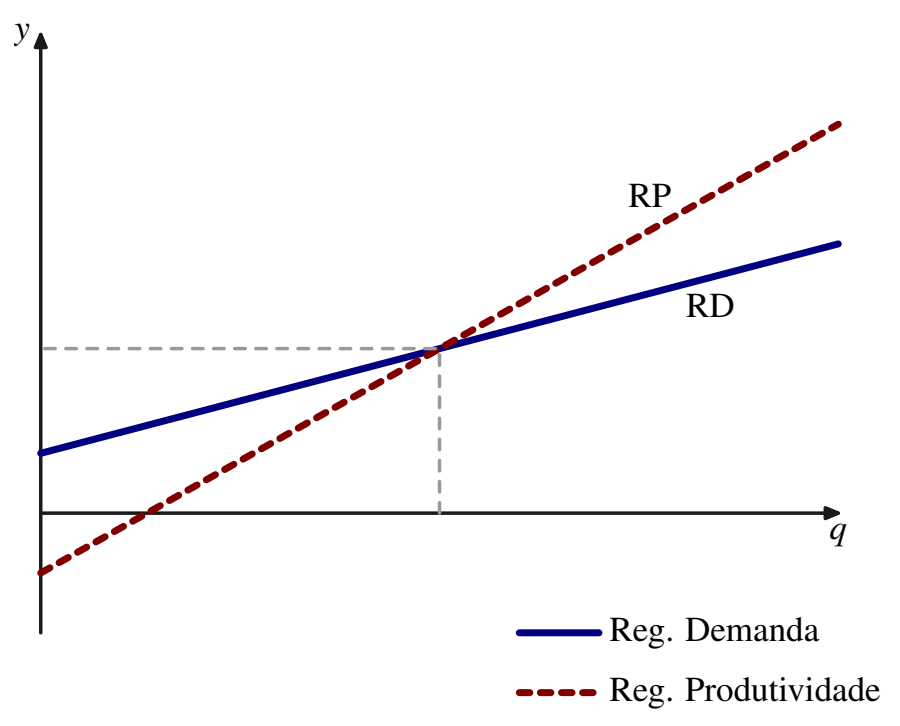

Figura 4.11: Regimes macroeconômicos.

Substituindo a equação (4.15) na equação (4.3), obtemos:

$$
\begin{gathered}
q=r+\alpha \beta A+\alpha \beta \phi q \\
q-r-\alpha \beta \phi q-\alpha \beta A=0 .
\end{gathered}
$$


Para garantir a estabilidade do equilíbrio, temos que garantir que

$$
\frac{d}{d q}=1-\alpha \beta \phi>0
$$

Logo,

$$
\alpha \beta \phi<1
$$

Substituindo os parâmetros originais nos parâmetros estruturais, conclui-se que a condição de estabilidade do equilíbrio é dada por

$$
\frac{\theta_{2}+n+\psi}{1-\lambda-\theta_{1}+\pi}<\frac{1}{\alpha}
$$

Ou seja, o modelo é estável no caso das elasticidades-renda serem maiores que as elasticidadespreço na razão $1 / \alpha$. Esta demonstração da estabilidade do equilíbrio ${ }^{12}$ é bastante interessante, pois expressa toda substância teórica que está embutida nesta linha de modelos, ou seja: o ajuste via renda é maior que o ajuste via preço. A demonstração apenas clarifica a escolha teórica: usase este tipo de modelos porque acredita-se que o ajuste via quantidades é maior que o ajuste via preços.

\subsection{Evidências empíricas - Brasil anos 2000}

O intuito desta seção é analisar empiricamente os fundamentos do modelo para um período especifico da economia brasileira. Em particular, pretende-se discutir como esses fundamentos podem ser considerados para explicar a diferença entre o crescimento econômico brasileiro na década de 2000, em comparação à década anterior.

Para atingir este fim, o procedimento empírico contará com duas etapas. Na primeira etapa, recorrer-se-á à estimação das equações que compõem o Regime de Demanda e o Regime de Produtividade, tal como especificados na seção anterior. A estimação destas equações será feita para o período 1991-2008 com dados trimestrais e será incluída uma variável dummy de intercepto e declividade para o período 2003-2008, objetivando captar as mudanças estruturais dos parâmetros nos dois períodos. É exatamente a significância desta variável dummy que indicará a direção das transformações no modelo ou, graficamente, como se comportam as curvas do Regime de Demanda e do Regime de Produtividade (ver gráfico da Figura 4.11). Em seguida, utilizar-se-ão os parâmetros estimados nestas equações para inferir o comportamento dos parâmetros das equações fundamentais do modelo - equações (4.3) e (4.15).

\footnotetext{
${ }^{12}$ Note-se que $d 2 q / d q=0$, garantindo a condição de segunda ordem para a estabilidade do equilíbrio.
} 
Dessa forma, empiricamente, os períodos 1991-2002 e 2003-2008 serão tratados como dois distintos episódios discretos de crescimento, caracterizados por diferentes regimes macroeconômicos, da mesma forma como Setterfield e Cornwall (2002) analisam os períodos 1945-73 e pós 1973, embora os autores não tenham recorrido a um teste econométrico mais formal, limitandose a mostrar a evolução numérica das séries em questão. Da mesma forma, Campo e Taylor (1998) fazem uma análise interessante do efeito de diferentes políticas - entre elas a abertura econômica - em um modelo próximo ao que foi adotado neste ensaio, mas também não endereçam um episódio mais específico de crescimento. Já Naastepad (2006) utiliza a mesma metodologia de duas etapas de estimação, a saber, uma etapa de estimação dos parâmetros e uma etapa seguinte de análise da participação destes parâmetros nas equações fundamentais do modelo. O autor analisa a experiência de crescimento, no período 1960-2000, utilizando dados em séries de tempo para a Holanda. Entretanto, seu foco não foi a transformação de diferentes episódios de crescimento, mas sim computar o peso dos parâmetros estimados no crescimento do período, com ênfase na característica wage-led $^{13}$ da economia holandesa e suas consequências no comércio exterior. Setterfield (2010) avança consideravelmente na parte teórica e contribui, através de seus resultados teóricos, para a discussão de episódios de crescimento.

Assim, o experimento empírico aqui realizado reunirá a metodologia de estimação em duas etapas, como proposto por Naastepad (2006), com a caracterização de diferentes episódios de crescimento (SETTERFIELD; CORNWALL, 2002) gerados por diferentes políticas (CAMPO; TAYLOR, 1998) em um modelo Kaldoriano de causação cumulativa, com o embasamento teórico de Setterfield (2010).

A estimação de todas as equações foi feita com base na técnica de Mínimos Quadrados Ordinários em primeiras diferenças. Ainda que o estudo tenha considerado os problemas típicos ${ }^{14}$ da estimação por Mínimos Quadrados no que se refere aos dados em séries de temporais, a adoção de um período relativamente curto de análise minimiza o problema de perda de informação de longo prazo das séries econométricas, possibilitando a execução deste exercício. Fundamentalmente, a adoção de Mínimos Quadrados Ordinários se faz importante pela restrição temporal dos dados no período considerado de mudança estrutural (2003-2008), já que por meio deste método se conseguirá introduzir mais claramente a quebra estrutural dos parâmetros através de

\footnotetext{
${ }^{13}$ Conforme discutido na seção anterior, o modelo estimado neste ensaio previamente impossibilita um comportamento wage-led, uma vez que a função consumo adotada não diferencia o consumo de capitalistas e trabalhadores e a função investimento não inclui diretamente a lucratividade.

${ }^{14}$ Caso as séries temporais envolvidas sejam (potencialmente) geradas por processos estocásticos nãoestacionários, uma regressão por mínimos quadrados poderá ser espúria. A estimação por primeiras diferenças, ainda que solucione o problema da regressão espúria, corre o risco de perder a informação de longo prazo da série. $\mathrm{Na}$ presença desses problemas, se recomendaria a estimação por meio da técnica de Cointegração, que se aplicaria ao caso das variáveis em questão serem integradas de ordem 1. Para melhor esclarecimentos consultar Enders (2004).
} 
variáveis dummies de constante e declividade. ${ }^{15}$

Sendo assim, na primeira etapa do teste empírico foram utilizados os dados ${ }^{16}$ descritos a seguir e estimadas as seguintes equações:

\section{Função consumo (4.5):}

$$
c=c_{0}+\lambda y
$$

onde $c$ é a variação do consumo para dados trimestrais e $y$ é a variação do PIB Nacional, ambas as séries dessazonalizadas e retiradas das Contas Nacionais Brasileiras computadas pelo IBGE, enquanto $c_{0}$ e $\lambda$ são os parâmetros de constância e declividade da função consumo.

\section{Função investimento (4.7):}

$$
i=i_{0}+\theta_{1} y+\theta_{2}\left(p_{d}-e-p_{f}\right)
$$

onde $i$ é o logaritmo da formação bruta de capital para dados trimestrais e $y$ é a variação do PIB Nacional, ambas as séries dessazonalizadas e retiradas das Contas Nacionais Brasileiras computadas pelo IBGE. Já $\left(p_{f}-e-p_{d}\right)$ é o logaritmo do câmbio real brasileiro trimestral, em que $e$ é o câmbio nominal, $p_{f}$ são os comercializáveis norte-americanos (IPA-EUA), e $p_{d}$ são os não-comercializáveis locais (IPCA-IBGE), de modo que foi adotada a medida de câmbio real mais tradicionalmente utilizada. Dessa forma o parâmetro $i_{0}$ é a constante e os parâmetros $\theta_{1} \mathrm{e}$ $\theta_{2}$ são as respectivas elasticidades renda e câmbio do investimento.

\section{Função Exportação (4.9):}

$$
x=\eta\left(p_{d}-e-p_{f}\right)+\epsilon z
$$

onde $x$ é o logaritmo das exportações brasileiras trimestrais reais (série em dólares deflacionada pelo IPC americano), computadas pelo $\mathrm{BCB},\left(p_{f}+e-p_{d}\right)$ é o logaritmo do câmbio real brasileiro trimestral (mesma série utilizada na função investimento) e $z$ é o logaritmo do comércio externo mundial (Exportações mais Importações mundiais, computadas pelo WDI-World Development Indicators). A sazonalidade das séries envolvidas foi controlada através de dummies sazonais. O parâmetro $\eta$ é a elasticidade-preço da demanda por exportações e $\epsilon$ é a elasticidade-

\footnotetext{
${ }^{15}$ Embora existam métodos para se introduzir uma quebra estrutural no Vetor de Cointegração, através, por exemplo, de tendências associadas com dummies, ou divisão das séries, esses métodos, ou não captam exatamente alterações nos parâmetros de declividade, ou não são possíveis para quebras estruturais no final da série. Por outro lado, a introdução de dummies de declividade diretamente no vetor de cointegração não é um procedimento correto, pois altera a função de distribuição, como coloca Seo (1995).

${ }^{16}$ Os dados, cuja fonte original será descrita na apresentação das equações, foram retirados do site do IPEA-Data.
} 
renda da demanda por exportações.

\section{Função Importação (4.11) :}

$$
m=\psi\left(p_{f}+e-p_{d}\right)+\pi y,
$$

onde $m$ é o logaritmo das importações brasileiras trimestrais reais (série em dólares deflacionada pelo IPC americano), computadas pelo $\mathrm{BCB},\left(p_{f}+e-p_{d}\right)$ é o logaritmo do câmbio real brasileiro trimestral (mesma série utilizada na função investimento) e y é o logaritmo do PIB real dessazonalizado (IBGE). A sazonalidade das séries envolvidas foi controlada através de dummies sazonais. Os parâmetros $\psi$ e $\pi$ são, respectivamente, a elasticidade-preço da demanda por importações e a elasticidade-renda da demanda por importações.

\section{Função Produtividade (4.3):}

$$
q=r+\alpha y,
$$

onde $q$ é uma medida de variação da produtividade do trabalho, resultado da razão entre produção industrial dessazonalizada (dado da PIM-PF-IBGE) e pessoal empregado na indústria, índice dessazonalizado (dado do CNI). Já y representa a variação do PIB (mesma medida da função consumo). O parâmetro $r$ representa uma medida de produtividade autônoma e o parâmetro $\alpha$ representa o coeficiente de Verdoorn para o Brasil.

Os resultados das estimações podem ser visualizados na Tabela 4.5.

Uma vez concluída a primeira etapa de estimações, resta analisar os efeitos da variação dos parâmetros das equações estimadas (medido através das variáveis dummies de intercepto e declividade para o período 2003-2008) nos parâmetros das equações estruturais (equações (4.3) e (4.15)). Para visualizar esse efeito, utilizamos a Tabela 4.6, que mostra a direção e magnitude da variação dos parâmetros das equações estimadas e seu efeito no parâmetro estrutural.

Essa configuração de parâmetros e suas variações, leva à uma expressão gráfica do modelo para a economia brasileira entre 1990 e 2000, como se pode ver na Figura 4.11. Nesta análise gráfica do modelo, o período 1991-2002 pode ser representado pelo Equilíbrio A e o período 2003-2008 pode ser representado pelo Equilíbrio B com uma taxa de crescimento do produto e da produtividade maior em razão do deslocamento do Regime de Demanda.

Em primeiro lugar, convém notar que, no caso brasileiro, o regime de demanda é negativamente inclinado. Ou seja, aumentos de demanda aumentam y e $q$, simultaneamente. Enquanto aumentos do Regime de Produtividade aumentam $q$, mas diminuem $y$. Dada a especificação 
Tabela 4.5: Coeficiente das estimações das equações do modelo.

\begin{tabular}{|c|c|c|c|c|c|}
\hline & Equação 1 & Equação 2 & Equação 3 & Equacão 4 & Equacão 5 \\
\hline Variável Dependente & c & $i$ & $x$ & $m$ & $q$ \\
\hline \multicolumn{6}{|l|}{ Variáveis Independentes } \\
\hline$c o$ & $\begin{array}{r}0,19 \\
{[49.12]}\end{array}$ & & & & \\
\hline$y$ & $\begin{array}{r}0,79 \\
{[0.00]}\end{array}$ & $\begin{array}{r}1,48 \\
{[0.00]}\end{array}$ & $\begin{array}{r}0,85 \\
{[0.00]}\end{array}$ & $\begin{array}{r}4,58 \\
{[0.00]}\end{array}$ & $\begin{array}{r}1,22 \\
{[0.00]}\end{array}$ \\
\hline io & & $\begin{array}{c}-2,09 \\
{[0.00]}\end{array}$ & & & \\
\hline - [pd-pf-e]' & & $\begin{array}{c}-0,23 \\
{[0.00]}\end{array}$ & $\begin{array}{r}0,01 \\
{[0.86]}\end{array}$ & $\begin{array}{c}-0,70 \\
{[0.00]}\end{array}$ & \\
\hline \multicolumn{6}{|l|}{$z$} \\
\hline$"-r / a$ & & & & & $\begin{array}{r}-0,03 \\
{[0,01]}\end{array}$ \\
\hline Dummy 2003-2008 & Não Significante & Não Significante & Não Significante & Não Significante & Não Significante \\
\hline Dummy Anos 2003-2008 * y(declividade) & Não Significante & $\begin{array}{r}-0,02 \\
{[0.00]}\end{array}$ & $\begin{array}{r}0,42 \\
{[0.00]}\end{array}$ & $\begin{array}{r}-0,01 \\
{[0.05]}\end{array}$ & Não Significante \\
\hline Dummy Anos 2003-2008 * (pd-pf-e)(decliv) & & Não Significante & Não Significante & $\begin{array}{r}\mathbf{0 , 3 4} \\
{[0.03]}\end{array}$ & \\
\hline \multicolumn{6}{|c|}{ Estatísticas de Regressão } \\
\hline R-squared & 0,3 & 0,95 & 0,982562 & 0,970134 & 0,339000 \\
\hline Adjusted R-squared & 0,27 & 0,95 & 0,980312 & 0,966281 & 0,309403 \\
\hline S.E. of regression & 1,72 & 0,04 & 0,074676 & 0,098612 & 0,037862 \\
\hline Sum squared resid & 197,49 & 0,1 & 0,345746 & 0,602905 & 0,096047 \\
\hline Log likelihood & $-137,06$ & 136,14 & 88,283340 & 68,543330 & 133,754100 \\
\hline Durbin-Watson stat & 2,29 & 0,96 & 1,125329 & 1,479074 & 2,275392 \\
\hline Mean dependent var & 0,88 & 4,639060 & 9,688151 & 9,490543 & 0,010392 \\
\hline S.D. dependent var & 2,01 & 0,169488 & 0,532202 & 0,537019 & 0,045561 \\
\hline Akaike info criterion & 3,97 & $-3,670578$ & $-2,233334$ & $-1,677277$ & $-3,655046$ \\
\hline Schwarz criterion & 4,1 & $-3,544097$ & $-1,946515$ & $-1,390458$ & $-3,527571$ \\
\hline F-statistic & 9,55 & 458,652100 & 436,672900 & 251,745900 & 11,453840 \\
\hline Prob(F-statistic) & 0 & 0,000000 & 0,000000 & 0,000000 & 0,000004 \\
\hline
\end{tabular}

Tabela 4.6: Efeito da quebra no parâmetro estrutural.

\begin{tabular}{|c|c|c|}
\hline \multicolumn{2}{|r|}{ Parâmetros estimados } & Efeito parâmetro estrutural \\
\hline$c_{0}$ & Consumo autônomo & $A \rightarrow$ \\
\hline$\lambda$ & Consumo-Renda & $\beta \rightarrow$ \\
\hline$i_{0}$ & Investimento autônomo & $A \rightarrow$ \\
\hline$\theta_{1}$ & Elastic Renda Invest & {$[-0.02]$} \\
\hline$\theta_{2}$ & Elast Câmbio Invest & $\phi \rightarrow$ \\
\hline$\eta$ & Elastic Câmbio Export & $\phi \rightarrow$ \\
\hline$\epsilon$ & Elast Renda Export & $A \uparrow \quad[+0.42]$ \\
\hline$\psi$ & Elastic Câmbio Import & $\phi \uparrow \quad[+0.34]$ \\
\hline$\pi$ & Elastic Renda Import & $\beta \rightarrow$ \\
\hline$r$ & Produtiv Autônoma & $r \rightarrow$ \\
\hline$\alpha$ & Coefic. Verdoorn & $\alpha \rightarrow$ \\
\hline
\end{tabular}

do modelo que foi desenvolvido, isso pode ser explicado por uma alta elasticidade-renda das importações que tornou o $\beta>0$, e uma resposta do investimento e das importações ao câmbio maiores em módulo (negativas) que o efeito positivo do cambio sobre as exportações, que tornou $\phi<0$. Devido a esta configuração de parâmetros, o Regime de Demanda é negativamente inclinado.

Note-se que, entre os dois períodos, verificou-se uma pequena diminuição, de proporções bastante reduzidas, na elasticidade-renda do investimento $(-0,02)$, o que diminuiria o multiplicador $\beta$. Este comportamento pode ser justificado pelo aumento da participação do Investimento na renda; ou seja, o investimento no período cresce um pouco mais do que seria explicado pelo aumento de renda, diminuindo sua elasticidade. Outra alteração no período foi uma redução 


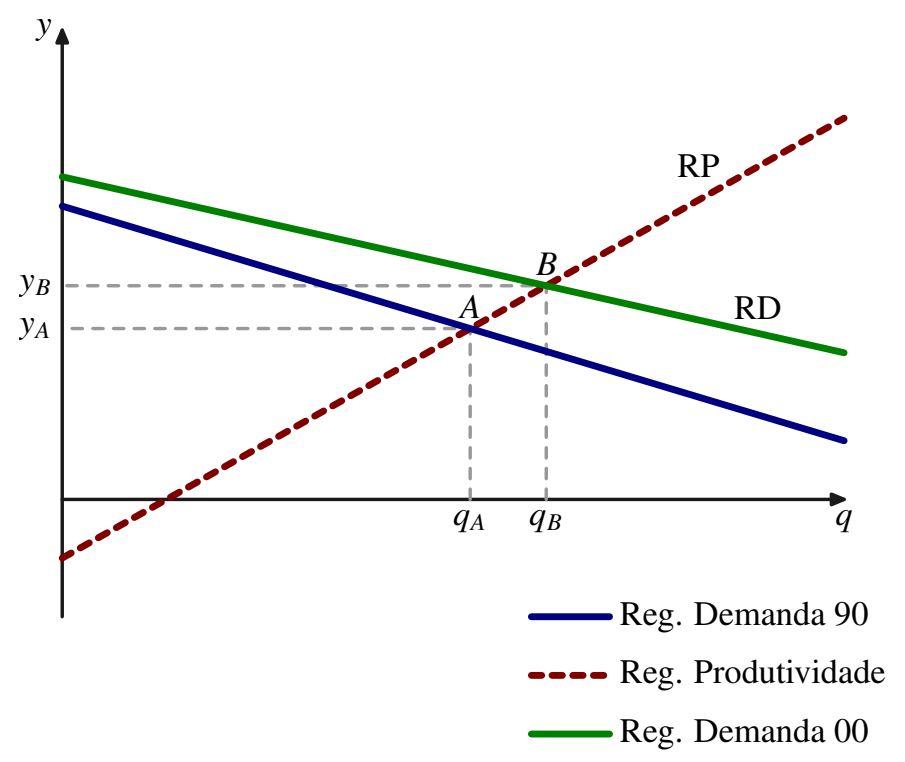

Figura 4.12: Regimes macroeconômicos Kaldorianos.

em módulo da elasticidade-câmbio das importações, aumentando o parâmetro estrutural $\phi$ da equação de demanda, o que provoca uma demanda mais inclinada, mais elástica.

O principal parâmetro que mostrou uma variação significativa e positiva $(+0,42)$ foi a elasticidade-renda das exportações, que causa um aumento no parâmetro estrutural $A$ do Regime de Demanda, ou seja, um deslocamento para cima na função demanda. Os demais parâmetros não mostraram variações significativas entre os dois períodos.

É importante ressaltar que a elasticidade-renda das exportações que apresentou a maior variação, é a variável de maior importância para a análise kaldoriana. Entretanto, isto não significa que as exportações foram as únicas responsáveis pelo aumento de produto. A característica principal do modelo são os mecanismos retroalimentadores entre oferta e demanda, e entre mercado interno e externo, fundamentada pela relação entre o aumento de produto e produtividade (Regime de Produtividade). Sendo assim, um comportamento positivo das exportações foi a principal causa de um aumento do produto pelo lado da demanda, que causou um aumento de produtividade (Lei de Verdoon) que, por sua vez, levou a um aumento do produto que atingiu todos os componentes sensíveis à renda do lado da demanda (Consumo, Investimento, Importações).Este, por sua vez, ocasionou a um aumento de produtividade e o processo se seguiu com intensidade cada vez menor, até se exaurir.

Vejamos numericamente os equilíbrios, já que o modelo linear possibilita a solução algébrica. Computou-se os resultados dos agregados econômicos nos períodos (1990-2008) e (2003-2008), baseados nos parâmetros que estimamos, e comparou-se com o comportamento real das variáveis. A Tabela 4.7 mostra os valores. 
Tabela 4.7: Estimações do modelo e do Real.

\begin{tabular}{|c|c|c|c|c|c|c|}
\hline \multicolumn{3}{|c|}{$\begin{array}{c}\text { Modelo I - 1991-2008 } \\
\begin{array}{c}q=1.22 y \\
y=2.82-0.28 q\end{array}\end{array}$} & \multicolumn{2}{|c|}{$\begin{array}{c}\text { Modelo II 2003-2008 } \\
q=1.22 y \\
y=4.54-0.19 q\end{array}$} & \multicolumn{2}{|c|}{$\begin{array}{cc}\text { Diferença } & \text { Diferença } \\
\text { Mod I e II } & \text { Real } \\
\text { Mod II - Mod I } & 91-08 \text { - 03-08 }\end{array}$} \\
\hline & Modelo & Real & Modelo & Real & Modelo & Real \\
\hline$y$ & 2.1 & 3.0 & 3.7 & 4.2 & 1.6 & 1.2 \\
\hline$q$ & 2.6 & 2.5 & 4.5 & 3.0 & 1.9 & 0.5 \\
\hline$c$ & 1.9 & 3.0 & 3.1 & 3.9 & 1.3 & 1.0 \\
\hline 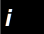 & 0.4 & 4.2 & 2.3 & 8.3 & 1.9 & 4.1 \\
\hline$x$ & 11.3 & 11.3 & 16.7 & 21.5 & 5.5 & 10.3 \\
\hline$m$ & 7.4 & 14.0 & 15.3 & 24.4 & 8.0 & 10.4 \\
\hline sto & $\begin{array}{l}\text { e separas } \\
\text { que o m }\end{array}$ & $\begin{array}{l}\text { I repr } \\
\text { períod } \\
91-200 \\
\text { lo foi es }\end{array}$ & lo pa & $\begin{array}{l}8, \text { qu } \\
\text { do o }\end{array}$ & $\begin{array}{l}\text { par } \\
1-200 \\
\text { y } 200\end{array}$ & $\begin{array}{l}\text { quanto } \\
1 \text { meto } \\
\text { comp } \\
8, \text { que }\end{array}$ \\
\hline
\end{tabular}

Note que o modelo prevê crescimento em todas as variáveis econômicas $y, q, c, i, x$ e $m$, como pode-se ver na penúltima coluna da tabela. Os dados reais corroboram esse aumento, mas mostram que o modelo subestimou o aumento principalmente nas variáveis $i$ e $x$. A diferença no investimento pode ter uma fonte exógena, como um aumento de investimentos públicos, que o modelo não captaria. Já quanto à diferença nas exportações, que é bastante grande, pode estar relacionada à hipótese adotada de que $e=p f$, ou seja, que as variações dos preços externos foram captadas pelo câmbio nominal e, portanto, as alterações de câmbio real significativas se devem a variações de preços internos. Essa hipótese pode ter sido muito forte quando se trata de preço de exportações, pois os termos de troca tiveram um comportamento diferente do câmbio nominal no período, como pode-se ver no gráfico da Figura 4.13. Ou seja, essa é uma possível explicação para a ineficiência do modelo quando tratamos de exportação, aliada à medida de cambio real adotada, que pode ter errado mais para exportações que para importações, dados os parceiros comerciais. Uma outra explicação complementar é que captamos o aumento da elasticidade-renda entre 2003-2008, mas consideramos o produto externo como sendo a média do período, quando sabemos que ele também foi maior no período 2003-2008 (4,0\% contra $3,6 \%$ no período total).

De fato, aquelas diversas suposições que fecharam canais de transmissão entre oferta e demanda, setor externo e interno, podem ter sido responsáveis pela minimização do poder explicativo para algumas variáveis do modelo, mas, por outro lado, conseguimos um bom poder preditivo deixando apenas um canal aberto, a relação entre produto e produtividade.

Em termos de estabilidade, o modelo é estável nos dois equilíbrios, já que satisfazem a 


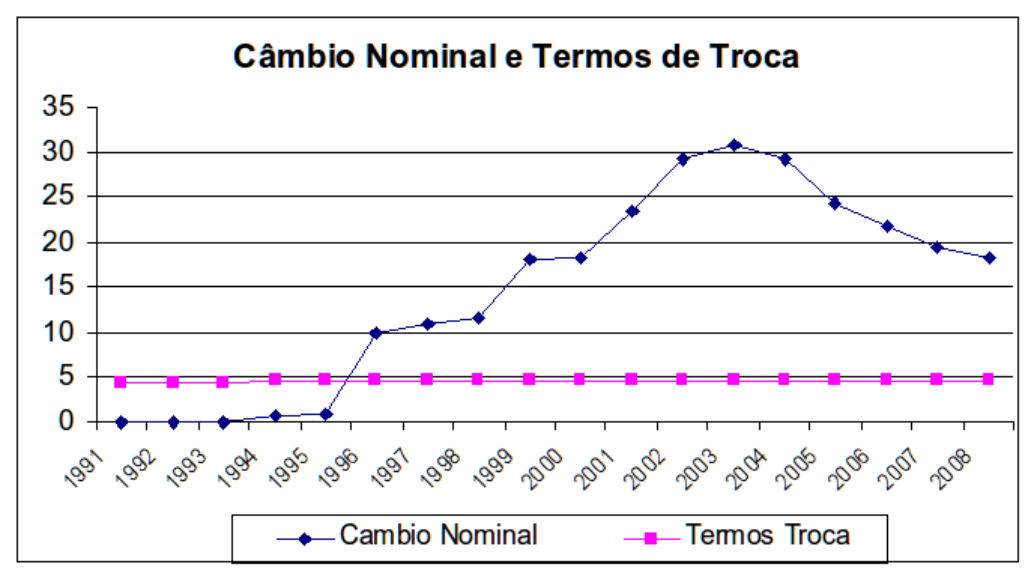

Figura 4.13: Termos de troca e câmbio real. Fonte: Ipea.

condição de equilíbrio:

$$
\begin{array}{cl} 
& \frac{\theta_{2}+n+\psi}{1-\lambda-\theta_{1}+\pi}<\frac{1}{\alpha} \\
\text { Modelo I (91-08): } & \frac{-0,92}{3,31}<0,81 \\
\text { Modelo II (03-08): } & \frac{-0,58}{3,18} \prec 0,81
\end{array}
$$

O gráfico da Figura 4.14 faz uma simulação da convergência para o equilíbrio. Note que o modelo, mesmo partindo de um produto distante do equilíbrio, $Y_{0}=0,01$, converge rapidamente para o equilíbrio após 4 ou cinco períodos.

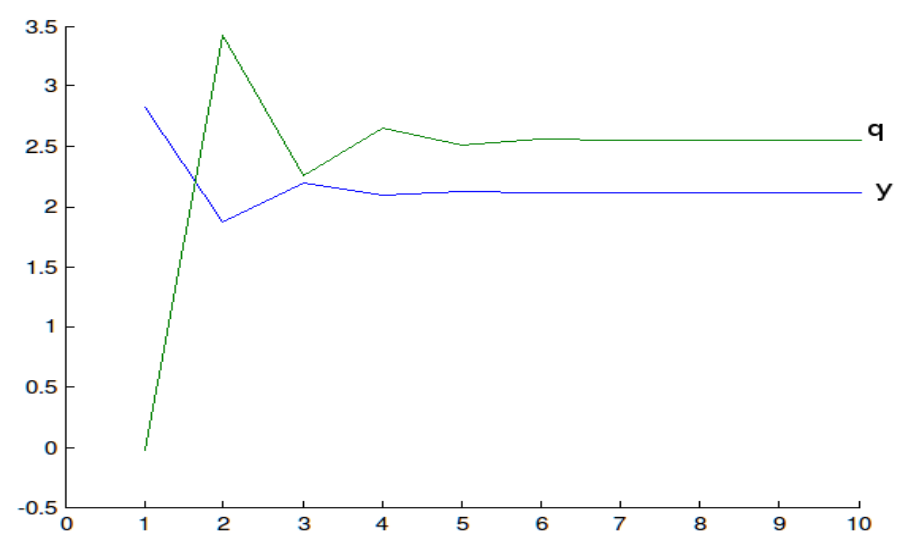

Figura 4.14: Simulação da trajetória de convergência.

De qualquer forma, de acordo com o modelo aqui desenvolvido e suas fundamentações empíricas, o que explica um maior crescimento no período 2003-2008 foi um Regime de Demanda mais favorável, que fez com que operassem os efeitos de causação cumulativa na economia. Desta forma, foi possível que algumas das transformações econômicas do lado da oferta, já 
presentes nos anos 1990 (positivas em termos de produtividade do trabalho e ganhos de eficiência), finalmente contribuíssem para melhorar os resultados macroeconômicos e principalmente o crescimento do PIB.

\subsection{Considerações finais}

O presente ensaio teve por fim investigar os aspectos centrais do episódio de crescimento da economia brasileira entre 2003-2008, baseado em um modelo Kaldoriano de causação cumulativa, já que uma primeira análise de cenário sugere que a interação entre demanda e oferta, setor interno e externo, foi importante para explicar a economia brasileira no período.

Verificamos que a economia brasileira apresentou crescimento no período 2003-2008 em relação ao período 1991-2002, em diversas variáveis internas e externas, incluindo o PIB. A restrição externa ao crescimento do produto em termos agregados foi reduzida, com um aumento do intercepto e da elasticidade das exportações. Isso explicaria uma diminuição da restrição de demanda e, portanto, o aumento do PIB.

Entretanto, quando analisamos quebras estruturais nos parâmetros da restrição externa, como melhora nas elasticidades de exportações, espera-se que esse processo tenha sido resultado de transformações estruturais internas, como melhora e adensamento da pauta exportadora, e por essa razão o ensaio anterior relaciona a restrição externa a processos de transformação estrutural. A especificidade para o caso brasileiro, neste período, é que o alívio da restrição externa via exportações não foi acompanhado por uma melhora da pauta exportadora. Inferiu-se este resultado através de dois indicadores: o comportamento do EXPY ${ }^{17}$ (Figura 4.6) e a Lei de Thirlwall Multi-Setorial ${ }^{18}$, que também aponta uma piora da pauta exportadora (Figura 4.8). Assim, surgem questões sobre a origem do alívio desta restrição e, principalmente, sobre como foi a disseminação destes resultados positivos para o resto da economia.

Prosseguindo a análise, percebemos que o alívio da restrição externa não teve como causa uma transformação da estrutura produtiva, mas uma transformação importante no mercado internacional. Constatamos um aumento expressivo de exportações para China, pais que cresce muito (o que justifica a quebra de intercepto) e cresce mais que a economia mundial (o que justifica a quebra na elasticidade).

A partir do momento que constatamos que essa transformação foi exógena - em outras

\footnotetext{
${ }^{17} \mathrm{O}$ índice EXPY foi construído no Ensaio I e mede a renda ponderada média associada a pauta exportadora do país.

${ }^{18}$ Análise feita a partir de Gouvêa e Lima (2010).
} 
palavras, o pais mudou sua posição no mercado internacional por meio da transformação do mercado internacional e não por uma transformação interna —, inicia-se o questionamento sobre a qualidade do crescimento brasileiro no período. Recorremos então ao modelo Kaldoriano de causação cumulativa.

O modelo mostrou claramente que um impulso inicial foi dado pelo aumento da elasticidaderenda das exportações, que estimulou a economia através da retroalimentação entre oferta e demanda dada pelo regime de produtividade. Assim, principalmente, o aumento da elasticidaderenda das exportações deslocaram o Regime de Demanda para cima ocasionando um aumento do PIB, da produtividade, do consumo, do investimento, das importações e exportações, sendo que o resultado previsto pelo modelo aproxima-se dos dados reais, mostrando sua efetividade.

O que pode-se concluir a partir destes resultados? O crescimento brasileiro foi de qualidade ou foi apenas uma mera decorrência da transformação do mercado externo? É possível um crescimento sustentável sem transformação produtiva? O processo de crescimento da economia brasileira neste período pode ser chamado de desenvolvimento, ou de um embrião de um processo mais profundo de desenvolvimento? O objetivo aqui é discutir os rumos de longo prazo a partir da análise estrutural de um período curto de tempo (2003-2008).

Na verdade, a discussão proposta acima demandaria a construção de um novo ensaio; porém, pode-se inferir algo, com base na análise desenvolvida ao longo dessa tese. Primeiramente, não parece que o processo de crescimento brasileiro tenha sido um uma mera decorrência das transformações do mercado internacional, dado que o pais internalizou esse crescimento através da retroalimentação de oferta e demanda. Alem disso, alguns indicadores de melhora na distribuição de renda, redução da pobreza, melhora no mercado de trabalho, aumento da classe media, ainda que modestos, demonstram que o processo não limitou-se apenas ao crescimento do PIB. Assim, defende-se que o processo de crescimento do período teve alguma qualidade e pode vir a ser um embrião de um processo mais profundo de desenvolvimento.

Entretanto, conforme discutido no Ensaio I, o aumento sustentável e duradouro do nível de renda per capita só e atingido através da melhoria da pauta exportadora e importadora, que representa a mudança estrutural de um modelo de desenvolvimento. Assim, se este cenário não induzir um processo de aumento da competitividade estrutural, ele pode ser transitório. Portanto, a recomendação deste trabalho, em geral, é sempre usar estes ciclos virtuosos para promover uma melhoria da pauta de comercio exterior e da competitividade de modo geral; só assim seria possível vivenciar um processo de desenvolvimento.

Portanto, dois cenários se colocam. No primeiro, a economia brasileira vivenciou um período de crescimento onde impulsos do setor externo foram internalizados, porém, se nada indi- 
car que esse processo se estenderá a uma transformação da estrutura produtiva, ele se extinguirá na medida em que o efeito retroalimentador se exaurir.

Em um segundo cenário, a economia brasileira vivenciou um período de crescimento de qualidade, onde impulsos do setor externo foram internalizados para variáveis além do PIB, e que tem diversas características que nos permitem acreditar que seja um período embrionário de um processo de desenvolvimento mais amplo, que envolva transformações de estrutura produtiva, competitividade externa, aproveitando este ciclo virtuoso de crescimento.

Em termos da linha de argumentação desta tese, esse último ensaio apresentou de maneira bastante explícita uma forma de contaminação positiva do setor externo sobre as demais variáveis internas, entre elas o produto. 


\section{Considerações finais: competitividade externa e desempenho econômico na década de 2000 - relações, canais de transmissão e contribuições à literatura}

Nesta tese analisou-se o papel da competitividade externa sobre o desenvolvimento econômico na década de 2000. Diversos estudos, como os de Prebisch (2000) e grande parte da literatura cepalina, Thirlwall e Hussain (1982), Krugman (1980), Krugman (1989), Bertil Ohlin (1933), Frankel e Romer (1996), Hausmann, Hwang e Rodrik (2005), entre muitos outros citados ao longo deste trabalho, concentraram-se na discussão do desempenho econômico baseados em uma economia aberta ao comércio exterior. Entretanto, os autores diferem fortemente sobre quais seriam as influências e os canais de transmissão entre o setor externo e o desempenho econômico.

A questão torna-se ainda mais relevante na década de 2000, devido às bruscas transformações das décadas anteriores no mercado internacional, com a entrada no mercado de países ex-comunistas, com a abertura da América Latina e principalmente com a inserção planejada de grandes economias como a China e a Índia. Essas transformações fizeram com que, na década de 2000, as economias estivessem lutando pela sua posição no mercado internacional e esse reposicionamento provavelmente mudou a trajetória de crescimento econômico de longo prazo de países como a China, a Índia, os países mais ricos, e provavelmente outros países específicos. Ou seja, a posição no mercado internacional afetou diretamente o desempenho das economias na década de 2000 e, portanto, é a principal razão para que esta seja a periodicidade desta tese.

Ainda assim, a questão do posicionamento das economias no mercado internacional não está na agenda desta década no mainstream do desenvolvimento econômico, que está concentrando seus estudos em provar a essencialidadade do capital humano para explicar as diferenças entre os desempenhos dos países, ou desenvolver modelos histórico-institucionais (na linha de 
Acemoglu, Johnson e Robinson (2001)) ou modelos de inovações tecnológicas para explicar as diferenças da Produtividade Total de Fatores (na linha de Aghion e Howitt (1992)). Entretanto, alguns trabalhos sobre desempenho econômico e comércio externo tem sido conduzidos por Hausmann, Hwang e Rodrik (2005), entre outros, e é compartilhando dessa preocupação com a competitividade externa que este trabalho se insere, ainda que faça uso de canais de propagação mais amplos que os colocados por esses autores.

Dessa forma, esta tese é composta de três ensaios que investigam a competitividade externa e o desempenho das nações na década de 2000. De maneira geral, o primeiro ensaio prova empiricamente, com base no experimento empírico conduzido, a importância da qualidade da pauta de comércio exterior no desempenho econômico e, a partir dos resultados obtidos, comenta alguns canais de transmissão entre comércio externo e renda presentes nas teorias de crescimento econômico. O segundo ensaio lança mão do modelo de crescimento sob restrição externa para reiterar a importância da competitividade estrutural no crescimento, utilizando uma nova metodologia empírica que permite uma análise para todos os países conjuntamente. O terceiro ensaio elabora um modelo Kaldoriano que explica como as economias internalizam, em termos do crescimento do produto e de outras variáveis internas, as modificações no comércio internacional; este modelo é aplicado ao Brasil, permitindo assim uma discussão sobre o desempenho da economia brasileira no período 2003-2008. Dessa maneira, os três ensaios foram elaborados para responder às seguintes questões: Competitividade externa é importante para o desempenho econômico? Quais os canais relevantes de propagação entre desempenho do setor externo e desempenho econômico?

Mais especificamente, o Ensaio I investigou as conexões empíricas entre a competitividade externa e a determinação do nível de renda e do crescimento econômico para a década de 2000, relacionando os resultados empíricos com os modelos teóricos que investigam essa conexão. Assim, a primeira contribuição do Ensaio I à literatura é a construção, para a década de 2000, de um índice de qualidade da pauta exportadora e outro índice de qualidade da pauta importadora, com base em 1240 produtos e 143 países. O cálculo da renda média ponderada associada à pauta exportadora (qualidade da pauta exportadora) foi baseado no estudo de Hausmann, Hwang e Rodrik (2005), que calculam esse índice para o período 1992-2003. A contribuição deste artigo é, então, não apenas verificar a evolução do índice nesta década, mas também estendê-lo para a pauta importadora, uma vez que se acredita que o desempenho econômico possa ser de alguma forma afetado também pela qualidade das importações, o que é corroborado por alguns modelos de crescimento como o de Inovações Industriais Intencionais e o de Crescimento sob Restrição Externa. 
A partir da construção desses índices, fez-se um teste empírico para uma cross-section de países, uma pooled regression e um painel de efeito fixo, onde a variável dependente foi nível de renda per capita e as variáveis independentes foram as tipicamente usadas em um modelo de Solow (capital físico, capital humano, trabalho, instituições), acrescidas do índice de qualidade da pauta exportadora. $\mathrm{O}$ exercício foi refeito utilizando-se o índice de qualidade da pauta importadora. A variável de qualidade da pauta exportadora mostrou-se significante quando fizemos o exercício para uma cross section de países em 2005 e quando fizemos uma pooled regression da década. Já quando fizemos um painel, introduzindo o efeito específico, a significância da variável desaparece. Para diversos autores que trabalham nesta linha de modelos, como Islam (1995), Hall e Jones (1999) e Ferreira, Pessoa e Velloso (2005), o efeito específico é a Produtividade Total de Fatores, que explica grande parte do crescimento atual. Os resultados do Ensaio I sugerem que na Produtividade Total de Fatores, ou no resíduo que não pode ser explicado pelo acumulo de fatores, está embutida a qualidade da pauta exportadora, ou a competitividade externa medida pelas exportações. Verifica-se o mesmo resultado para a competitividade medida pelas importações. Em outras palavras, na Produtividade Total de Fatores está a competitividade externa tal como medida pelos índices de qualidade da pauta exportadora e importadora, pois somente quando introduzimos a Produtividade Total de Fatores (efeito específico) é que a significância da competitividade externa desaparece. Isso significa que a produtividade de fatores depende dos produtos exportados e importados. Logo, o fato de especializar-se em alguns produtos é melhor para o desempenho econômico que se especializar em outros.

O exercício também possibilita um estudo do crescimento futuro, pois os países que têm um nível de renda per capita mais baixo que o permitido por sua competitividade externa tendem a crescer mais; este é o caso da China, de parte dos países asiáticos, do Brasil, da Argentina, enfim, da maioria dos países em desenvolvimento. Já os países que têm um nível de renda per capita maior que o compatível com sua competitividade externa tendem a crescer menos, como é o caso de grande parte dos países desenvolvidos. Por outro lado, grande parte dos países pobres têm um nível de renda per capita compatível com sua baixa competitividade externa, e a taxa de crescimento tende a ficar estagnada, a não ser que estes países procurem mudar sua competitividade externa. Assim, uma segunda contribuição do Ensaio I à literatura foi comprovar a existência de uma relação empírica entre competitividade externa, tal como medida pelos índices de qualidade da pauta exportadora e importadora e do desempenho econômico.

A terceira contribuição do Ensaio I foi utilizar os índices de qualidade da pauta exportadora e importadora e os resultados dos testes empíricos para discutir as questões colocadas pela literatura teórica de crescimento, demonstrando que a relação entre competitividade externa e desempenho econômico acontece através de canais mais amplos do que os inicialmente 
concebidos por Hausmann, Hwang e Rodrik (2005). Por exemplo, os dados não corroboram a teoria das vantagem comparativas, pois a própria significância dos índices de qualidade de pauta exportadora e importadora já questiona essa teoria, uma vez que aquilo que o país exporta e importa é significante para o crescimento. No caso dos modelos de concorrência monopolística, os resultados não comprovam, para a desagregação de quatro dígitos, a afirmação de que o crescimento esteja associado a um maior número de variedades exportadas. Já a relevância da competitividade das importações e a inexistência de uma correlação negativa entre produtos bons de exportar e importar evidenciam algum papel para a transferência tecnológica, tal como nos Modelos de Inovações Industriais Intencionais. Os modelos de crescimento sob restrição externa são corroborados à medida que as elasticidades-renda das importações e das exportações nada mais são do que indicadores da qualidade das importações e exportações. Da mesma forma, os dados não contradizem o canal de Falhas de Mercado; na verdade, a ocorrência de falhas de mercado é uma explicação bastante convincente de por que a qualidade da pauta exportadora e a qualidade da pauta importadora são variáveis relevantes, embora os testes elaborados não testem diretamente estes canais. Já da teoria kaldoriana podemos retirar diretamente dois pontos que condizem com os nossos dados: a ideia de que alguns setores podem estar associados a uma maior produtividade e a relevância do setor de bens de capital no processo de crescimento. A visão neo-schumpeteriana é corroborada na medida em que se verifica que produtos com maior qualidade de exportação são produtos de maior tecnologia de acordo com a classificação da UNCTAD. A visão neo-estruturalista também é corroborada uma vez que grande parte dos produtos com menor qualidade exportadora são produzidos em um ambiente competitivo.

Já o Ensaio II teve, como primeira contribuição, demonstrar, através de um teste empírico baseado em um modelo de crescimento sob restrição externa para 137 países, que países com elevadas elasticidades-renda das importações (baixa qualidade da pauta importadora) cresceram menos, para um dado comportamento das exportações. Em outras palavras, a relação entre crescimento e elasticidade-renda das importações é inversamente proporcional. O resultado vale no longo prazo (1980-2004), mas não vale para o período aqui destacado (2000-2008), que é bastante curto. Não significa também que a restrição externa não é relevante, significa apenas que ainda não estamos em um longo prazo suficiente para que ela se imponha como uma restrição relevante e que deva ser respeitada. Isso também não significa que realizar a análise da restrição externa para um período curto como a década de 2000 não acrescente nada. Ao contrário, podemos fazer diversas análises sobre essa diferença nos resultados de curto e de longo prazo: primeiramente, para a década de 2000, não apenas o câmbio, mas também o fluxo de capitais se mostrou significante, o que leva as economias a se afastarem da restrição imposta 
por sua competitividade estrutural. Uma segunda hipótese que parece se comprovar é a de que, na década de 2000, o papel da política econômica para transformar a restrição externa e a posição das economias no mercado internacional foi exaltado, e em vários países pode-se verificar políticas ativas neste sentido, utilizando-se entre outras políticas, as do câmbio e do movimento de capitais.

Entretanto, a maior contribuição do Ensaio II foi a de propor uma nova metodologia de teste do modelo de crescimento sob restrição externa, o que possibilitou a elaboração de um teste conjunto, isto é, para um conjunto de países, sem recair em grande parte dos problemas de endogeneidade apontados por McCombie (McCOMBIE, 1989; McCOMBIE, 1997), utilizando dados em painel. Assim, foi possível recuperar a análise de crescimento sob restrição externa, não apenas para estudar episódios de crescimento isolados, mas também para auferir resultados mais gerais, como no Ensaio II.

O Ensaio III faz um estudo de caso para o Brasil na década de 2000, que permite dar alguma contribuição para o debate da economia brasileira no período e cumprir um papel na lógica de argumentação da tese, ou seja, explicitar um canal através do qual uma economia internaliza os ganhos no setor externo. Assim, a primeira contribuição do Ensaio III é a elaboração de um modelo Kaldoriano que permite uma interação retroalimentadora entre elementos de oferta e de demanda, assim como uma interação entre setor externo e o mercado interno, explicitando um canal através do qual uma economia internaliza os ganhos no setor externo. O modelo foi aplicado para o Brasil na década de 2000, mais especificamente entre 2003 e 2008. O modelo mostrou claramente que a economia vivenciou um ciclo virtuoso de crescimento retroalimentador onde um comportamento positivo das exportações, provocado por transformações no mercado internacional, foi a principal causa de um aumento do produto pelo lado da demanda, que causou um aumento de produtividade (Lei de Verdoon) que, por sua vez, propiciou um aumento do produto que atingiu todos os componentes sensíveis à renda do lado da demanda (Consumo, Investimento, Importações). Este último, por sua vez, levou a um aumento de produtividade; e este processo deve seguir com intensidade cada vez menor, até se exaurir. A interpretação desses resultados é a segunda contribuição do Ensaio III para literatura, que consiste na discussão sobre a experiência brasileira de crescimento entre 2003-2008 e a contribuição deste período para a trajetória de crescimento de longo prazo. Ou seja, o que se pode concluir a partir dos resultados do ensaio? O crescimento brasileiro foi de qualidade ou foi apenas uma mera decorrência da transformação do mercado externo? É possível um crescimento sustentável sem transformação produtiva? O processo de crescimento da economia brasileira neste período pode ser chamado de desenvolvimento, ou de um embrião de um processo mais profundo de desenvolvimento? Todas essas questões emergem naturalmente do trabalho, e algumas conjecturas 
preliminares são feitas a partir do estudo realizado na tese de maneira geral.

Dessa forma, esta tese tece uma teia de argumentos que esclarecem o papel fundamental que a competitividade externa, ou que a competitividade estrutural possui sobre o desempenho econômico das nações. Ressalte-se que o último termo utilizado, competitividade estrutural, foi empregado com o intuito de garantir que o leitor não interprete erroneamente os principais preceitos da tese. O setor externo não é importante porque toda a dinâmica macroeconômica depende das exportações e importações, entendidas como componentes do PIB. O setor externo é importante porque ele explicita a competitividade estrutural da economia, que por sua vez determina o nível de renda per capita relativo de longo prazo e as taxas de crescimento necessárias para atingir esse determinado nível de renda. Em outras palavras, serão as condições de oferta interna, entendidas de forma muito mais ampla e complexa que a simples escassez ou abundância de fatores produtivos, que determinarão a estrutura produtiva que estará interagindo no mercado internacional. Por essas razões, a tese é um estudo do setor externo sobre a competitividade estrutural interna e relativa das economias. Parte dessa discussão está contemplada no Ensaio II quando se estabeleceu uma clara relação entre o estruturalismo e os modelos de crescimento sob restrição externa.

Da mesma forma, nos modelos utilizados nos Ensaios II e III, a demanda é primordial na determinação do nível de renda e do crescimento econômico. Entretanto, ao menos na concepção desenvolvida nesta tese, a demanda é relevante simplesmente porque é imprescindível para a análise de qualquer fenômeno econômico a interação existente entre oferta e demanda. No modelo de crescimento sob restrição externa, não obstante seja um modelo de crescimento liderado pela demanda, as elasticidades-renda das exportações e das importações refletem a competitividade estrutural da economia, ou seja, as condições de oferta interna entendidas de forma mais ampla. No modelo desenvolvido no Ensaio III, essa interação entre oferta e demanda é direta e expressa nos Regimes de Demanda e de Produtividade, ou seja, existe uma elasticidade da oferta em relação à demanda e da demanda em relação à oferta. Considerando dessa perspectiva, os modelos de crescimento baseados apenas na oferta, e que consideram a oferta como a simples escassez ou abundância de alguns fatores produtivos, parecem muito mais restritos para compreensão de fenômenos econômicos como o desempenho das nações.

É provável que essa rigidez de foco na oferta, aliado à também rígida definição de oferta, subestime o papel da competitividade externa no desempenho econômico, uma vez que, nessa visão, todas as demais variáveis, por construção, devem ajustar-se à escassez ou à abundância dos fatores produtivos considerados relevantes. Por consequência, uma variedade de fatores econômicos, que está embutida nos produtos de país, fica fora da análise, como, por exemplo: 
competitividade dos mercados, capacidade de geração, indução e transferência de tecnologia, efeitos sobre a demanda e dessa sobre a oferta, dependência temporal no processo de desenvolvimento devido a falhas de mercado como Cost Discovery, Learning-by-Doing ou Efeitos de Rede, restrições de demanda, composição de oferta e de demanda. Enfim, diversas informações contidas em um produto que ficam fora da análise. Por essa razão, quando tentamos explicar o desempenho econômico com base nos produtos comercializados pelo país, obtemos algum êxito, pois estamos indiretamente considerando todos estes aspectos que ficariam de fora em uma análise via modelo de Solow, por exemplo.

Por fim, espera-se que esta tese tenha contribuido para uma melhor compreenção dos determinantes do desempenho das nações, focando na questão da competitividade externa, que, conforme desenvolvemos acima, nos permite considerar uma série de aspectos do funcionamento econômico. Dessa forma, a tese pretende contribuir tanto para a discussão da gigantesca discrepância nos níveis de renda entre nações, quanto para a compreenção de alguns episódios particulares de crescimento, especialmente o correspondente à experiência brasileira de desenvolvimento. 


\section{Referências Bibliográficas}

ACEMOGLU, D.; JOHNSON, S.; ROBINSON, J. The colonial origins of comparative development: an empirical investigation. The American Economic Review, v. 91, n. 5, p. 1369-1401, dez. 2001.

AGHION, P.; HOWITT, P. Model of growth through creative destruction. Econometrica, v. 60, n. 2, p. 323-351, mar. 1992.

ALONSO, J. A.; Garcia Matrín, C. A new approach to balance-of-payments constraint: some empirical evidence. Journal of Post Keynesian Economics, v. 21, n. 2, 1998.

ANSARI, H.; XI, Y. The chronicle of economic growth in Southeast Asian countries: does Thirlwall's Law provide an adequate explanation. Journal of Post Keynesian Economics, v. 22, n. 4, Summer 2000.

ARAÚJO, R. A.; LIMA, G. T. A structural economic dynamics approach to balance-ofpayments-constrained growth. Cambridge Journal of Economics, v. 31, n. 5, p. 755-774, 2007.

ARROW, K. J. The economic implications of learning by doing. Review of Economic Studies, v. 29, p. 155-173, jun. 1962.

ATESOGLU, H. S. Balance-of-payments-coinstrained growth: Evidence from the United States. Journal of Post Keynesian Economics, v. 15, n. 4, Summer 1993.

ATESOGLU, H. S. An explanation of the slowdown in the US economic growth. Applied Economics Letters, 1995.

BARBOSA-FILHO, N. The balance-of-payments constraint: from balanced trade to sustainable debt. Banca Nazionale del Lavoro Quarterly Review, n. 219, 2001.

BARRO, R. J.; Sala-i-Martin, X. Economic Growth. [S.1.]: McGraw-Hill, 2004.

BÉRTOLA, L.; HIGACHI, H.; PORCILE, G. Balance-of-payments-constrained growth in Brazil: a test of Thirlwall's Law, 1890-1973. Journal of Post Keynesian Economics, v. 25, n. 1, 2002.

BEZERRA, R. S.; OREIRO, J. L.; LEMOS, B. P. Real exchange rate, capital mobility and structural change in a modified Kaldorian model of cumulative causation. In: Anais do XXXVI Encontro Nacional de Economia [Proceedings of the 36th Brazilian Economics Meeting]. [S.l.: s.n.], 2008.

BIELSCHOWSKY, R. Cinqüenta anos de pensamento da CEPAL - uma resenha. In: BIELSCHOWSKY, R. (Ed.). Cinqüenta anos de Pensamento da CEPAL. [S.1.]: Record, 2000. 
BRITO, G.; McCOMBIE, J. Thirlwall's law and the long-term equilibrium growth rate: an application to Brazil. Journal of Post Keynesian Economics, v. 32, n. 1, p. 115-36, 2009.

BRODA, C.; WEINSTEIN, D. E. Variety growth and world welfare. The American Economic Review, v. 94, n. 2, 2004.

CAMPO, O.; TAYLOR, L. Trade liberalization in developing economies: modest benefits but problems with productivity growth, macro prices, and income distribution. Working Paper, n. 8, 1998. CEPA, New School, Nova York.

CARVALHO, V.; LIMA, G.; SANTOS, A. A restrição externa como fator limitante do crescimento econômico brasileiro: um teste empírico. Economia, v. 9, n. 2, 2008.

CARVALHO, V. R. da S.; LIMA, G. T. Estrutura produtiva, restrição externa e crescimento econômico: a experiência brasileira. Economia e Sociedade, v. 18, n. 1, abr. 2009.

CASS, D. Optimum growth in an aggregative model of capital accumulation. The Review of Economic Studies, v. 32, n. 3, p. 233-240, jul. 1965.

CHENERY, H.; ROBINSON, S.; SYRQUIN, M. Industrialization and Growth: A Comparative Study. [S.1.], 1986.

CHRISTOPOULOS, D. A reassessment of balance-of-payments-coinstrained growth: results from panel unit root and panel cointegration tests. International Economic Journal, 2003.

CIMOLI, M. Heterogeneidad estructural, asimetrías tecnológicas y crecimiento en América Latina. MPRA Paper, n. 3832, 2005.

CIMOLI, M.; PORCILE, G.; ROVIRA, S. Structural change and the BOP-constraint: why did Latin America fail to converge? Cambridge Journal of Economics, v. 34, n. 2, p. 389-411, mar. 2010.

COE, D.; HELPMAN, E. International R\&D spillovers. European Economic Review, n. 39, p. 859-887, 1995.

CORNWALL, J.; CORNWALL, W. Growth theory and economic structure. Economica, v. 61, n. 242, p. 237-51, 1994.

DALUM, B.; LAURSEN, K.; VERSPAGEN, B. Does specialization matter for growth? Maastricht, 1996. Disponível em: <http:/meritbbs.unimaas.nl/tser/tser./html>.

DEANE, P. A. Evolução das idéias Econômicas. Rio de Janeiro: Zahar, 1980.

DIXIT, A.; STIGLITZ, J. Monopolistic competition and equilibrium product diversity. American Economic Review, n. 67, p. 297-308, 1977.

DIXON, R.; THIRLWALL, A. A model of regional growth rate differences along Kaldorian lines. Oxford Economic Papers, n. 27, p. 201-14, 1975.

DOMAR, E. Expansion and employment. The American Economic Review, v. 37, n. 1, p. 34-55, mar. 1947. 
DOSI, G.; FABIANI, S. Convergence and divergence in the long-term growth of open economies. In: SILVERBERG, G.; SOETE, L. (Ed.). The Economics of Growth and Technical Change. Technologies, Nations,Agents. Aldershot: Edward Elgar, 1994.

DUTT, A. Growth, Distribution and Uneven Development. [S.1.]: Cambridge University Press, 1990.

DUTT, A. Aggregate demand, aggregate supply and economic growth. International Review of Applied Economics, v. 20, n. 2, p. 319-36, jul. 2006.

ELLIOT, D.; RHODD, R. Explaining growth rate differences in highly indebted countries: an extention to Thirlwall and Hussain. Applied Economics, v. 31, set. 1999.

ENDERS, W. Apllied Econometric Time Series. 2. ed. [S.1.]: John Wiley \& Sons, 2004.

FAGERBERG, J. Technological progress, structural change and productivity growth: a comparative study. Structural Change and Economic Dynamics, n. 11, p. 393-411, 2000.

FERREIRA, A. A lei de crescimento de Thirlwall. Dissertação (Mestrado) - IE-Unicamp, 2001.

FERREIRA, P.; PESSOA, S. A.; VELLOSO, F. The evolution of international output differences (1960-2000): from factors to productivity. Ensaios Econômicos EPGE, jul. 2005.

FERREIRA, P.; ROSSI, J. New evidence from Brazil on trade liberalization and productivity growth. International Economic Review, v. 44, n. 4, p. 1383-1405, nov. 2003.

FERREIRA, P.; TREJOS, A. On the long-run efects of barriers to trade. Ensaios Econômicos da EPGE, n. 436, 2001. (mimeo).

FOLEY, D.; MICHL, T. Growth and Distribution. [S.1.]: Harvard University Press, 1999.

FRANKEL, D.; ROMER, D. Trade and growth: an empirical investigation. NBER Working Paper, n. 5476, 1996.

FRANKEL, M. The production function in allocation and growth: A synthesis. American Economic Review, v. 52, n. 5, p. 995-2022, dez. 1962.

GOUVÊA, R.; LIMA, G. Structural change, balance-of-payments constraint and economic growth: evidence from the multi-sectoral Thirlwall's Law. Journal of Post Keynesian Economics, 2010. (no prelo).

GREENE, W. H. Econometric Analysis. [S.1.]: Prentice Hall, 2008.

GROSSMAN, G.; HELPMAN, E. Product development and international trade. Journal of Political Economy, n. 97, p. 1261-1283, 1989.

GROSSMAN, G.; HELPMAN, E. Comparative advantage and long-run growth. American Economic Review, n. 80, p. 796-815, 1990.

GROSSMAN, G.; HELPMAN, E. Inovation and Growth in the global economy. Cambridge, MA: MIT Press, 1991. 
HALL, R.; JONES, C. Why do some countries produce so much more output per worker than others? Quarterly Journal of Economics, v. 114, p. 83-116, fev. 1999.

HAMILTON, J. Time Series Analysis. [S.1.]: Princeton University Press, 1994.

HARCOURT, G. Some Cambridge Controversies in the Theory of Capital. Cambridge: Cambridge University Press, 1972.

HARROD, R. International Economics. Cambridge: Cambridge University Press, 1933.

HAUSMANN, R.; HWANG, J.; RODRIK, D. What you export matters. NBER Working Paper, n. 11905, dez. 2005.

HAUSMANN, R.; KLINGER, B. Structural transformation and patterns of comparative advantage in product space. CID Working Paper, n. 128, 2006.

HAUSMANN, R.; RODRIK, D. Doomed to choose: Industrial policy as predicament. Paper prepared for the first Blue Sky seminar organized by the Center for International Development at Harvard University. set. 2006.

HIDALGO, C. et al. The product space conditions the development of nations. Science, v. 317, n. 5837, p. 482, jul. 2007.

HIRSCHMAN, A. Estratégia de Desenvolvimento Econômico. Rio de Janeiro: Fundo de Cultura, 1961.

HIRSCHMAN, A. The rise and decline of development economics. In: Essays in Trespassing: Economics to Politics and Beyond. [S.1.]: ???, 1981.

HOLLAND, M.; VIEIRA, F.; CANUTO, O. Economic growth and the balance-of-payments constraint in Latin America. Investigación Económica, LXIII, 2004.

HUSSAIN, M. The balance-of-payments constraint and growth rate differences among African and East Asian economies. African Development Review, jun. 1999.

ISLAM, N. Growth empirics: a panel data approach. Quarterly Journal of Economics, v. 110, n. 4, 1995.

JAYME, J. F. Balance-of-payments-constrained economic growth in Brazil. Revista de Economia Política, v. 23, 2003.

JEVONS, W. S. Theory of Political Economy. 11. ed. London: MacMillan, 1911.

JOHANSEN, S. Likelihood based inference in cointegrated vector auto-regressive models. [S.1.]: Oxford University Press, 1995.

KALDOR, N. Causes of the Slow Rate of Growth of the United Kingdom: an Inaugural Lecture. Cambridge: Cambridge University Press, 1966.

KALDOR, N. The case for regional policies. Scottish Journal of Political Economy, nov. 1970.

KALDOR, N. Economics Without Equilibrium. Armonk: M.E.Sharpe, 1985.

KALDOR, N. Causes of Growth and Stagnation in the World Economy. Cambridge:

Cambridge University Press, 1996. 
KELLER, W. Are international R\&D spillovers trade-related? analyzing spillovers among randomly matched trade partners. European Economic Review, n. 42, p. 1469-1481, 1998.

KEYNES, J. Teoria geral do emprego, do juro e da moeda. São Paulo: Atlas, 1992.

KLENOW, P.; RODRIGUEZ, A. The neo-classical revival in growth economics: has it gone too far. NBER Macroeconomics Annual, 1997.

KRUGMAN, P. Scale economies, product differentiation, and the pattern of trade. American economic Review, n. 70, p. 950-959, 1980.

KRUGMAN, P. Differences in income elasticities and trends in real exchange rates. European Economic Review, v. 33, n. 5, maio 1989.

LALL, S. The technological structure and performance of developing country manufactured exports, 1985-98. Oxford Development Studies, v. 28, n. 3, p. 337-69, 2000.

LEÓN-LEDESMA, M.; THIRLWALL, A. The endogeneity of the natural rate of growth. Cambridge Journal of Economics, v. 26, n. 4, p. 441-459, 2002.

LEWIS, W. O desenvolvimento econômico com oferta limitada de mão de obra. In: A Economia do Subdesenvolvimento. Rio de Janeiro: Forense, 1969.

LIBÂNIO, G. A. Aggregate demand and the endogeneity of the natural rate of growth: evidence from Latin American economies. Cambridge Journal of Economics, v. 33, n. 5, p. 968-84, 2009.

LIMA, G. T.; CARVALHO, V. R. da S. Estrutura produtiva, restrição externa e crescimento econômico: a experiência brasileira. Economia e Socoedade, v. 18, n. 1, abr. 2009.

LOPEZ, J.; CRUZ, A. Thirlwall's Law and beyond: the Latin American experience. Journal of Post Keynesian Economics, v. 22, n. 3, 2000.

LUCAS, J. R. E. On the mechanics of development planning. Journal of Monetary Economics, v. 22, n. 1, jul. 1988.

LUCAS, R. Econometric policy evaluation: A critique. In: BRUNNER, K.; MELTZER, A. (Ed.). The Phillips Curve and Labor Markets. New York: American Elsevier, 1976. (Carnegie-Rochester Conference Series on Public Policy, v. 1), p. 19-46.

MALTHUS, T. R. Ensaio sobre o Princípio da População. São Paulo: Ática, 1982. (Coleção Grandes Cientistas Sociais).

MANKIW, G.; ROMER, D.; WEIL, D. A contribution to the empirics of economic growth. Quarterly Journal of Economics, v. 107, n. 2, p. 407-437, 1992.

MARTINS, M. Padrões de eficiência no comércio: definições e implicações normativas. Nova Economia, v. 18, n. 2, p. 293-313, 2008.

MARX, K. O Capital. São Paulo: Nova Cultural, 1985.

MATSUYAMA, K. A simple model of sectoral adjustment. Review of Economic Studies, v. 59, n. 2, p. 375-388, abr. 1992. 
McCOMBIE, J. Law and balance of payments coinstrained growth: a comment on the debate. Applied Economics, n. 21, 1989.

McCOMBIE, J. On the empirics of balance-of-payments-constrained growth. Journal of Post Keynesian Economics, v. 19, n. 3, 1997.

McCOMBIE, J.; PUGNO, M.; SORO, B. Productivity Growth and Economic Growth: Essays on Verdoorn's Law. Basingstoke: Palgrave Macmillan, 2002.

McCOMBIE, J.; THIRLWALL, A. Economic growth and the balance of payments constraint. New York: St. Martin's Press, 1994.

McCOMBIE, J.; THIRLWALL, A. Economic growth and balance-of-payments constraint revisited. In: ARESTIS, P.; PALMA, G.; SAWYER, M. (Ed.). rowth and balance-of-payments constraint revisited. [S.1.]: Routledge, 1997. v. 2.

MCGREGOR, P.; SWALES, J. Professor thirlwall and balance of payments-constrained growth. Applied Economics, fev. 1985.

MENGER, C. Investigations into the method of the social sciences with special reference to economics. English translation by Francis J. Nock. New York: New York University Press, 1985.

MILL, J. S. Princípios de Economia Política. São Paulo: Nova Cultural, 1996.

MOREIRA, M. A indústria brasileira nos anos 90. O que já se pode dizer? In: GIAMBIAGI, F.; MOREIRA, M. (Ed.). A Economia Brasileira nos anos 90. [S.1.]: BNDES, 1999.

MORENO-BRID, J. On capital flows and the balance-of-payments constrained growth model. Journal of Post Keynesian Economics, v. 21, 1998.

MORENO-BRID, J. Mexico's economic growth and the balance-of-payments constraint: a cointegration analysis. International Review of Applied Economics, v. 13, n. 2, maio 1999.

MORENO-BRID, J. Capital flows, interest payments and the balance-of-payments constrained growth model: a theoretical and an empirical analysis. Metroeconomica, v. 54, n. 2, maio 2003.

MYRDAL, G. Economic Theory and Underdeveloped Regions. London: Duckworth, 1957.

NAASTEPAD, C. Technology, demand and distribution: a cumulative growth model with an application to the Dutch productivity growth slowdown. Cambridge Journal of Economics, v. 30, p. 403-34, 2006.

NAKABASHI, L. O modelo de thirlwall com variações nas elasticidades. Economia e Sociedade, v. 16, n. 1, 2007.

NURKSE, R. Problems of capital formation in underdeveloped countries. Oxford: Basil Blackwell, 1953.

NURKSE, R. Patterns of Trade and Development. The Wicksell Lectures for 1959. New York: Oxford University Press, 1961.

OHLIN, B. Interregional na Internationla Trade. Cambridge: Havard University Press, 1933. 
PACHECO-LOPEZ, P.; THIRLWALL, A. Trade liberalization, the income elasticity of demand for imports, and growth in Latin America. Journal of Post Keynesian Economics, v. 29, n. 1, 2006.

PREBISCH, R. O desenvolvimento econômico da América Latina e alguns de seus problemas principais. In: R. BIELSCHOWSKY. Cinqüenta anos de Pensamento da CEPAL. [S.1.]: Record, 2000.

QUESNAY, F. Quesnay's Tableau Economique. Marguerite Kuczynski and Ronald L. Meek (Eds.). London: Macmillan, 1972.

RAM, C.; KELLER, W. Techonology tranfer though imports. NBER Working Paper, n. 13086, 2007.

RAZMI, A. Balance of payments constrained growth model: the case of India. Journal of Post Keynesian Economics, v. 27, n. 4, p. 655-687, 2005.

RICARDO, D. On the Principles of Political Economy and Taxation. Cambridge University Press: Cambridge, 1951. Volume I of The Works \& Correspondence of David Ricardo edited by Piero Sraffa with the collaboration of M. H. Dobb.

RODRIGUES, M. Import substitution and economic growth. In: LACEA. Latin American and Caribbean Economic Association (LACEA) Meetings. Cidade do México: LACEA, 2006.

RODRIGUEZ, O. Teoria do Subdesenvolvimento da CEPAL. Rio de Janeiro: Forense Universitária, 1981.

ROMER, D. A simple general equilibrium version of the Baumol-Tobin model. The Quarterly Journal of Economics, v. 101, n. 4, p. 663-85, nov. 1986.

ROMER, P. M. Endogenous technological change. Journal of Political Economy, v. 98, p. S71-S102, out. 1990.

ROSENSTEIN-RODAN, P. Problems of industrialization of Eastern and South-Eastern Europe. Economic Journal, v. 53, n. 210/211, p. 202-211, 1943.

SAY, J.-B. Tratado de Economia Política. São Paulo: Abril Cultural, 1983.

SEERS, D. A model of comparative growth rates of the world economy. Economic Journal, mar. 1962.

SEN, A. Growth Economics. [S.1.]: Penguin Books, 1970.

SEO, B. Tests for structural change in cointegrated systems. Manuscript, 1995. University of Rochester.

SETTERFIELD, M. History versus equilibrium and the theory of economic growth. Cambridge Journal of Economics, v. 21, n. 3, p. 365-78, 1997.

SETTERFIELD, M. Endogenous growth: A Kaldorian approach. Working Papers, n. 1001, 2010. Trinity College, Department of Economics. 
SETTERFIELD, M.; CORNWALL, J. A neo-kaldorian perspective on the rise and decline of the Golden Age. In: SETTERFIELD, M. (Ed.). The Economics of Demand-led Growth. [S.1.]: Edward Elgar, 2002.

SILVERBERG, G.; SOETE, L. The Economics of Growth and Technical Change. Technologies, Nations, Agents. Aldershot: Edward Elgar, 1994.

SMITH, A. Riqueza das Nações. Lisboa: Fundação Calouste Gulbenkian, 1999.

SOLOW, R. A contribution to the theory of economic growth. Quartely Journal of Economics, v. 70, fev. 1956.

SOLOW, R. A technical change and the aggregate production function. Review of Economics and Statistcs, v. 39, p. 312-320, 1957.

TAVARES, M. da C. Auge e declínio do processo de substituição de importações no Brasil. In: BIELSCHOWSKY, R. (Ed.). Cinqüenta anos de Pensamento da CEPAL. [S.1.]: Record, 2000.

TAYLOR, L. Reconstructing Macroeconomics: Structuralist Proposals and Critiques of the Mainstream. [S.1.]: Harvard University Press, 2003.

THIRLWALL, A. The balance of payments constraint as an explanation of international growth rates differences. Banca Nazionale del Lavoro Quarterly Review, n. 128, 1979.

THIRLWALL, A. Foreign trade elasticities in centre-periphery models of growth and development. Banca Nazionale del Lavoro Quarterly Review, set. 1983.

THIRLWALL, A. Reflections on the concept of balance-of-payments-constrained growth. Journal of Post Keynesian Economics, v. 19, n. 3, 1997.

THIRLWALL, A.; HUSSAIN, M. The balance of payments constraint, capital flows and growth rates differences between developing countries. Oxford Economic Papers, v. 34, 1982.

UNCTAD. Trade and Development Report, 2002. [S.1.], 2002. Disponível em: <http://www.unctad.org/en/docs//tdr2002_en.pdf>.

VERDOORN, P. Verdoorn's Law in retrospect: A comment. Economic Journal, p. 382-85, jun. 1980.

VIEIRA, F. de A. C.; HOLLAND, M. Crescimento econômico secular no Brasil, modelo de Thirlwall e termos de troca. In: Anais do XXXIV Encontro Nacional de Economia. [S.1.]: ANPEC - Associação Nacional dos Centros de Pósgraduação em Economia, 2006.

WALRAS, L. Elementos de Economia Política Pura. São Paulo: Nova Cultural, 1996.

WOODRIDGE, J. Econometric Analysis of Cross-Section and Panel Data. [S.1.]: MIT Press, 2004. 


\section{ANEXO A - PRODYX e PRODYM (2 Dígitos) para 1999}

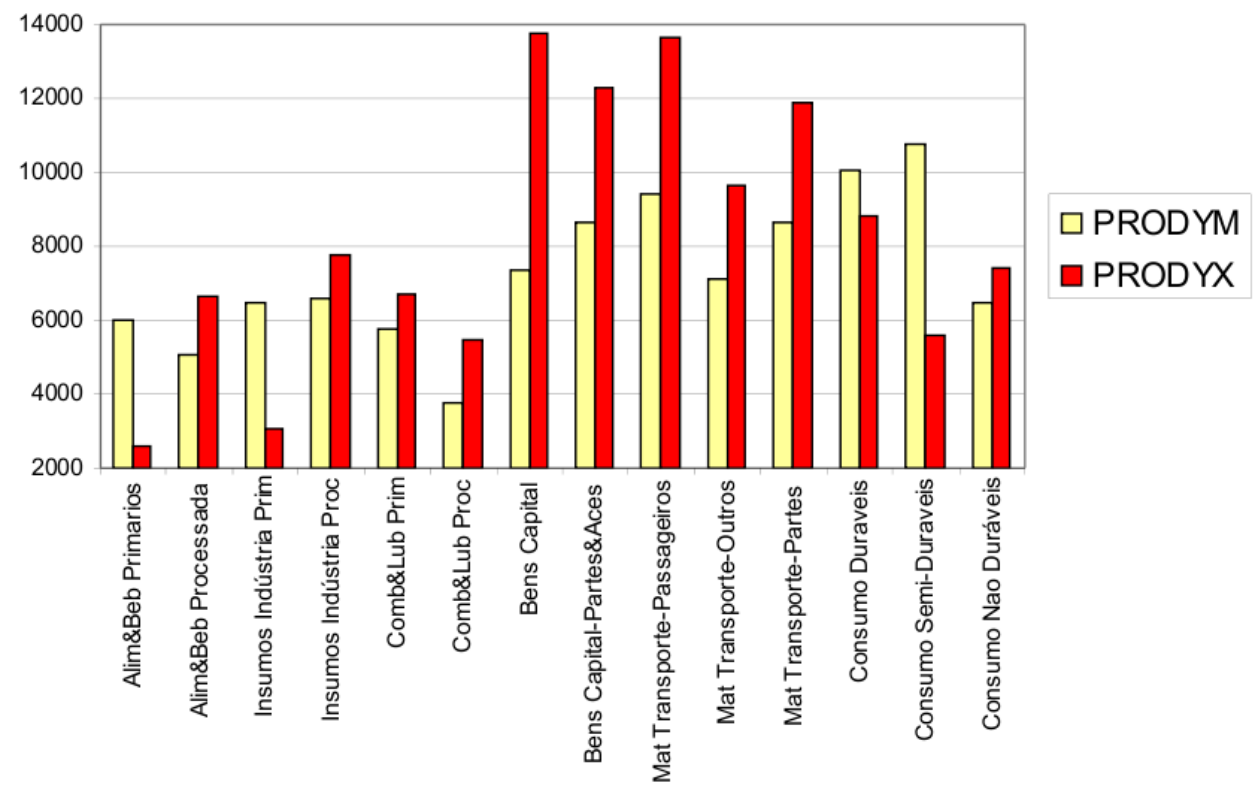

Figura A.1: PRODYM e PRODYX 2 dígitos. 


\section{ANEXO B - Lista de Produtos, PRODYX e PRODYM}

\begin{tabular}{|c|c|c|c|c|c|c|}
\hline Produto & PRODYX & PRODYM & & Produto & PRODYX & PRODYM \\
\hline 1 Live horses, asses, mules and hinnies & 12,962 & 14,387 & 3130 & Compounds, mixes of rare-earths, yttrium, scandium nes & 15541.3417 & \\
\hline 2 Live bovine animals & 5,821 & 6,254 & 314 & Hydrogen peroxide, (including solidified with urea) & 13933.1933 & 5998.48692 \\
\hline 3 Live swine & 13,045 & 14,916 & 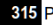 & Phosphides, excluding ferrophosphorus & 12195.2672 & 7428.39522 \\
\hline Live sheep and goats & 4,514 & 7,612 & 3160 & Carbides, whether or not chemically defined & 1879.19973 & 11925.0044 \\
\hline Live poultry, domestic fowls, ducks, geese, etc. & 8,251 & 5,268 & 317 & Hydrides, nitnides, azides, silicides and borides & 18891.0182 & 17663.4108 \\
\hline $\begin{array}{l}\text { Animals, live, except farm animals } \\
\text { and }\end{array}$ & $\begin{array}{l}0,447 \\
3,407\end{array}$ & $\begin{array}{r}0,200 \\
11,006\end{array}$ & 318 & Inorganic compounds,liquid/compressed air, amalgam nes & 16530.0445 & 5143.8131 \\
\hline 7 Meat of bovine animals, fresh or chilled & 6,335 & 11,608 & 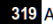 & Acyclic hydrocarbons & 12446.5104 & 11826.4823 \\
\hline Meat of bovine animals, frozen & 4,688 & 5,882 & $320 \mathrm{C}>2,2>0$ & Cyclic hydrocarbons & 13443.6767 & 8760.67345 \\
\hline Meat of swine, fresh, chilled or frozen & 9,953 & 10,738 & 321 & Halogenated derivatives of hydrocarbons & 13767.1754 & 6758.93156 \\
\hline 10 Meat of sheep or goats, fresh, chilled or frozen & 4,294 & 6,836 & 322 & Hydrocarbon derivs, sulphonated, nitrated, nitrosated & 4755.2108 & 4147.31681 \\
\hline 11 Horse, ass, mule, hinny meat, fresh, chilled or frozen & 5,861 & 22,253 & $323 \mathrm{~A}$ & Acyclic alcohols and their derivatives & 9801.35725 & 8320.99592 \\
\hline 12 Edible offal of domestic animals & 6,606 & 5,602 & 324 & Derivatives of cyclic alcohols & 9773.39105 & 11155.7132 \\
\hline 13 Meat, edible offal of domestic poultry & 8,324 & 4,340 & 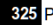 & Phenols and phenol-alcohols & 18828.3302 & 11141.9903 \\
\hline 14 Meat, edible meat offal nes, fresh, chilled or frozen & 5,407 & 15,611 & 326 & Derivatives of phenols or phenol alcohols & 3127.0944 & 10305.7556 \\
\hline 15 Pig and poultry fat, unrendered & 11,017 & 3,654 & 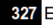 & Ether and derivatives & 14554.4695 & 12186.4025 \\
\hline 16 Salted, dried or smoked meat or offal, flour and meal & 11,435 & 9,110 & $328 \mathrm{E},>0$ & Epoxides, epoxyalcohols, -phenols -ethers, derivatives & 17573.4486 & 135292929 \\
\hline 17 Live fish & 5,130 & 15,823 & $329 \mathrm{~A}$ & Acetals and hemiacetals, derivatives & 23371.9507 & 9742.71915 \\
\hline 18 Fish, fresh or chilled, whole & 6,687 & 13,750 & $330 \mathrm{~A}$ & Aldehyde, its cyclic polymers, paraformaldehyde & 16721.5301 & 8572.96537 \\
\hline 19 Fish, frozen, whole & 4,839 & 5,036 & 331 & Hydrogenated, sulphonated and nitrated aldehydes & 22845.475 & 13814.4097 \\
\hline 20 Fish fillets, fish meat, mince except liver, roe & 11,506 & 14,458 & $332 \mathrm{~K}$ & Ketones and quinones, their derivatives & 16419.8218 & 11414.7643 \\
\hline Fish,cured, smoked, fish meal for human consumption & 2,896 & 8,116 & $333 \mathrm{~s}$ & Saturated acyclic monocarboxylic acids, derivatives & 11937.6867 & 8344.99136 \\
\hline 22 Crustaceans & 2,380 & 17,413 & 334 & Unsaturated acyclic, cyclic monocarboxylc acid, derivs & 10373.0606 & 9415.35827 \\
\hline 23 Molluscs & 2,594 & 15,062 & $335 \mathrm{P}$ & Polycarboxylic acid, derivatives & 10691.197 & 9192.23614 \\
\hline 24 Milk and cream, neither concentrated nor sweetened & 10,512 & 6,386 & 3360 & Carboxylic acids (additional oxygen function), derivs & 18515.7072 & 10975.7613 \\
\hline 25 Milk and cream, concentrated or sweetened & 4,669 & 3,409 & 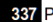 & Phosphoric esters, their salts and derivatives & 18231.235 & 9454.03814 \\
\hline 26 Buttermilk, cream, yogurt etc & 9,406 & 7,174 & 338 & Esters of inorganic acids nes, salts, derivatives & 15279.3499 & 8322.40938 \\
\hline 27 Whey, natural milk products nes & 7,602 & 7,558 & $339 \mathrm{~A}$ & Amine-function compounds & 18751.0135 & 15962.8127 \\
\hline 28 Butter and other fats and oils derived from milk & 7,123 & 5,271 & 3400 & Oxygen-function amino-compounds & 20915.5851 & 11118.2413 \\
\hline 29 Cheese and curd & 8,630 & 10,065 & 341 & Quaternary ammonium salts, hydroxides, lecithins, etc & 18408.4149 & 7700.34815 \\
\hline 30 Birds eggs, in shell, fresh, preserved or cooked & 5,150 & 4,529 & 342 & Carboxyamid-function compounds & 13711.7578 & 13322.0905 \\
\hline 31 Birds eggs, other than in shell, egg yolks & 11,933 & 7,060 & 3430 & Carboxyimide-function and imine-function compounds & 18311.0862 & 10200.9 \\
\hline 32 Honey, natural & 5,411 & 12,163 & 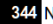 & Nitrile-function compounds & 13683.2526 & 9019.58878 \\
\hline 33 Edible products of animal origin, nes & 5,790 & 11,126 & 345 & Diazo-, azo- or azoxy-compounds & 9239.35319 & 11591.7285 \\
\hline 4 Hair, human, unworked, waste of human hair & 2,510 & 2,914 & $346 \mathrm{C}$ & Organic derivatives of hydrazine or of hydroxylamine & 9204.00948 & 13487.8914 \\
\hline 35 Bristle, hair (pig, badger), brush making hair, waste & 9,099 & 7,270 & 3470 & Compounds with other nitrogen function & 12334.3832 & 5370.79176 \\
\hline 36 Horsehair, waste & 1,245 & 7,528 & 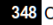 & Organo-sulphur compounds & 13653.9193 & 7916.41359 \\
\hline 37 Guts, bladders and stomachs of animals except fish & 4,605 & 9,257 & 3490 & Organo-inorganic compounds, nes & 7895.69057 & 9927.67566 \\
\hline Feathers, down, skins, other parts of birds, unworked & 13,903 & 10,671 & 350 & Heterocyclic compounds with oxygen hetero-atom(s) only & 25104.6965 & 17218.8663 \\
\hline 39 Bones and horm-cores unworked or simply worked & 4,033 & 20,722 & 351 & Heterocyclics, nitrogen hetero atom only, nucleic acid & 13526.9903 & 17380.77 \\
\hline 40 Ivory, whalebone etc, unworked, simply worked, unshaped & 2,483 & 17,574 & 352 & Heterocyclic compounds, nes & 9656.07383 & 17505.2363 \\
\hline 41 Coral, shell, cuttle bone, etc, unworked, and waste & 2,000 & 5,607 & $353 \mathrm{~s}$ & Sulphonamides & 14022.4719 & 12564.3577 \\
\hline 42 Sponges, natural, of animal origin & 4,269 & 8,607 & $354 \mathrm{P}$ & Provitamins and vitamins, their derivatives & 18321.6642 & 7632.69456 \\
\hline 43 Ambergris, civet, musk, etc for pharmaceutical use & 5,602 & 8,300 & 355 & Hormones, derivatives, steroids nes used as hormones & 22922.8608 & 18326.1521 \\
\hline 44 Animal products nes, dead animals (non-food) & 7,616 & 14,391 & $356 \mathrm{C}$ & Glycosides, salts, ethers, esters, other derivatives & 19097.1841 & 9872.51693 \\
\hline 45 Bulbs, tubers, corms, etc., chicory plant (non-food) & 3,584 & 12,691 & $357 \mathrm{~V}$ & Veg alkaloids, their salts, ethers, esters and derivs & 17755.3336 & 7977.60435 \\
\hline 46 Live plants nes, roots, cuttings, mushroom spawn & 4,173 & 12,071 & $358 \mathrm{~S}$ & Sugars, chem pure, their ethers, esters, salts in bulk & 18450.926 & 14811.4741 \\
\hline 47 Cut flowers, dried flowers for bouquets, etc, & 2,373 & 15,928 & 359 A & Antibiotics & 18610.0481 & 9993.66116 \\
\hline 48 Foliage etc except flowers for ornamental purposes & 4,535 & 17,181 & 360 & Organic compounds, nes & 1763.10199 & 3110.01091 \\
\hline 49 Potatoes, fresh or chilled & 6,148 & 4,658 & $361 c$ & Glands etc, dried, organ extracts, for therapeutic use & 20182.0234 & 15152.3474 \\
\hline 50 Tomatoes, fresh or chilled & 5,032 & 11,310 & $362 \mathrm{~B}$ & Blood, antisera, vaccines, toxins and cultures & 11807.8359 & 8596.19653 \\
\hline 51 Onions, shallots, garlic, leeks, etc. fresh or chilled & 1,580 & 4,324 & $363 \mathrm{~N}$ & Medicaments mixed together for therapeutic use, bulk & 12782.1229 & 6106.05695 \\
\hline 52 Cabbage, cauliffower, kohlrabi \& kale, fresh, chilled & 5,047 & 10,421 & $364 \mathrm{~N}$ & Medicaments, therapeutic, prophylactic use, in dosage & 17066.4333 & 8275.30507 \\
\hline 53 Lettuce and chicory, fresh or chilled & 10,983 & 16,029 & $365 \mathrm{~N}$ & Medical wadding, gauze, dressings etc & 12020.357 & 6720.43764 \\
\hline 54 Carrots, turnips, beetroot, etc. fresh or chilled & 7,340 & 8,022 & $366 \mathrm{~s}$ & Special pharmaceutical goods & 19576.3946 & 5911.04748 \\
\hline 55 Cucumbers and gherkins, fresh or chilled & 5,768 & 12,439 & $367 \mathrm{~A}$ & Animal or vegetable fertilizers, in packs $>10 \mathrm{~kg}$ & 10735.231 & 4304.81094 \\
\hline 56 Leguminous vegetables, fresh or chilled & 1,263 & 8,965 & $368 \mathrm{~N}$ & Mineral or chemical fertilizers, nitrogenous & 4914.27771 & 2629.15198 \\
\hline 57 Vegetables nes, fresh or chilled & 4,980 & 14,114 & $369 \mathrm{~N}$ & Mineral or chemical fertilizers, phosphatic & 4599.31744 & 2627.43056 \\
\hline 58 Vegetables (uncooked, steamed, boiled) frozen & 4,349 & 9,866 & 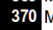 & Mineral or chemical fertilizers, potassic & 3429.94014 & 4136.63361 \\
\hline 59 Vegetables provisionally preserved, not ready to eat & 1,229 & 4,788 & $371 \mathrm{~F}$ & Fertilizer mixtures in packs of $<10 \mathrm{~kg}$ & 5544.93475 & 2738.79596 \\
\hline 60 Vegetables, dried, not further prepared & 2,379 & 9,332 & $372 \mathrm{~V}$ & Vegetable tanning extracts, tannins, salts and derivs & 5742.88224 & 4366.21473 \\
\hline 61 Vegetables, leguminous dried, shelled & 1,874 & 2,751 & $373 \mathrm{Ir}$ & Inorganic, synthetic organic tanning substances & 8072.13185 & 4779.99801 \\
\hline 62 Manioc, rrowroot, salep etc, fresh, dried, sago pith & 3,738 & 6,242 & $374 C$ & Colouring matter of vegetable or animal origin & 7686.51907 & 8448.57338 \\
\hline Coconuts, Brazil nuts and cashew nuts, fresh or dried & 261 & 9,403 & $375 \mathrm{~s}$ & Synthetic organic colouring matter & 15625.6115 & 7852.14151 \\
\hline Nuts except coconut, brazil \& cashew, fresh or dried & 3,770 & 12,382 & 376 & Colour lakes and preparations based thereon & 6186.24349 & 4754.55001 \\
\hline 65 Bananas, including plantains, fresh or dried & 3,769 & 9,898 & 3770 & Colouring matter nes, inorganic luminophores & 15577.1254 & 7411.93114 \\
\hline 66 Dates, figs, pineapple, avocado, guava, fresh or dried & 3,513 & 10,454 & $378 \subset$ & Ceramic, glass pigments, opacifiers, colours, enamels & 14460.7032 & 6172.01552 \\
\hline 67 Citrus fruit, fresh or dried & 5,300 & 9,374 & $379 \mathrm{P}$ & Polymer based paints, vamishes in non-aqueous medium & 11064.5984 & 6519.18714 \\
\hline Grapes, fresh or dried & 7,325 & 10,296 & $380 \mathrm{P}$ & Polymer based paints, vamishes in aqueous medium & 9974.35517 & 6546.75946 \\
\hline 69 Melons, watermelons and papaws (papayas), fresh & 3,911 & 12,383 & $381 P$ & Paints and varnishes nes, water pigments for leather & 5709.14517 & 4800.96353 \\
\hline 70 Apples, pears and quinces, fresh & 5,006 & 5,984 & $382 \mathrm{P}$ & Prepared driers & 9319.58292 & 3923.91793 \\
\hline 71 Stone fruit, fresh (apricot, cherry, plum, peach, etc) & 8,017 & 12,081 & 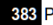 & Pigments for paint, stamping foils, dyes, retail & 14258.1501 & 6084.68978 \\
\hline 72 Fruits nes, fresh & 4,212 & 14,336 & $384 \mathrm{~A}$ & Artist, student or signwriter colours in small packs & 14293.4091 & 10022.765 \\
\hline 73 Fruits and nuts, uncooked boiled or steamed, frozen & 3,643 & 17,054 & $385 \mathrm{P}$ & Putty, mastics, painters fillers etc (non-refractory) & 12453.3804 & 7570.74027 \\
\hline 74 Fruits, nuts provisionally preserved, not ready to eat & 770 & 9,537 & 386 & Ink & 19725.5097 & 8321.60684 \\
\hline 75 Fruit, dried, nes, dried fruit and nut mixtures & 4,541 & 8,860 & 387 & Essential oils, resinoids and terpenic by-products & 4228.82268 & 7898.69043 \\
\hline Peel of citrus fruit or melons & 2,463 & 9,834 & $388 \mathrm{~N}$ & Mixted odoriferous substances for industrial use & 6649.43155 & 4177.44073 \\
\hline 77 Coffee, coffee husks and skins and coffee substitutes & 869 & 10,499 & $389 \mathrm{P}$ & Perfumes and toilet waters & 10211.5963 & 8984.62214 \\
\hline 78 Tea & 662 & 4,216 & $390 \mathrm{~B}$ & Beauty, make-up and skin care preparations & 8964.70439 & 9690.38976 \\
\hline 79 Mate & 4,393 & 5,697 & 391 & Hair preparations & 9245.11285 & 6538.55001 \\
\hline Pepper (Piper), crushed or ground Capsicum, Pimenta & 2,580 & 5,117 & 3920 & Oral and dental hygiene preparations & 6331.4725 & 4868.77912 \\
\hline Vanilla & 301 & 8,816 & $393 \mathrm{~s}$ & Shaving and toilet preparations nes, deodorizers & 13481.1761 & 7871.32517 \\
\hline 82 Cinnamon and cinnamon-tree flowers & 1,884 & 3,726 & $394 \mathrm{~s}$ & Soaps & 4836.67529 & 2905.99068 \\
\hline 83 Cloves (whole fruit, cloves and stems) & 576 & 6,156 & 3950 & Organic surface active agent, preparation, except & 10989.1936 & 6220.58919 \\
\hline 84 Nutmeg, mace and cardamons & 4,057 & 5,868 & $396 \mathrm{~L}$ & Lubricant, oils, textile, leather work, $<70 \%$ petroleum & 19822.5891 & 7089.61963 \\
\hline & 2,031 & 3,878 & 397 A & Artificial waxes and prepared waxes & 11482.2525 & 7411.7423 \\
\hline
\end{tabular}




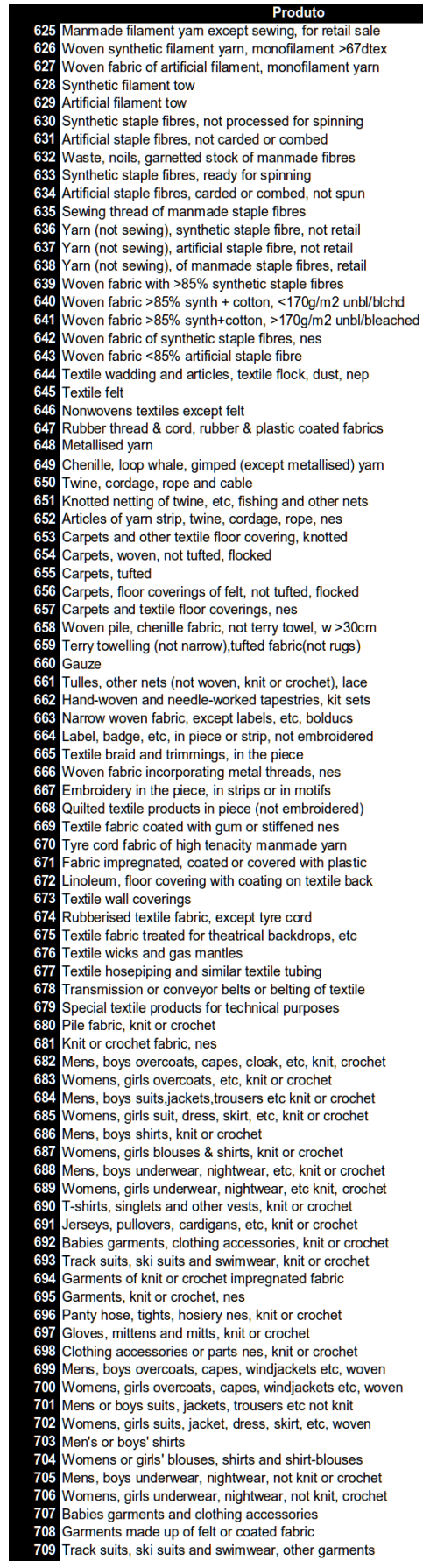

PRODYX

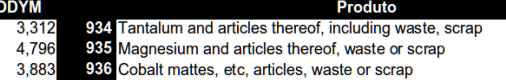

3,312
4,796
935 Tantalum and articles thereof, including waste, sc
3,883
936 Cognesium and articles thereof, waste or scrap
936

936 Cobalt mattes, etc, articles, waste or scrap
937 Bismuth, articles thereof, waste or scrap

937 Bismuth, articles thereof, waste or scrap
938 Cadmium, articles thereof, waste or scrap

5,139939 Titanium, articles thereof, waste or scrap

$\mathbf{5}, 814$
$\mathbf{9} 909$
$\mathbf{9 4 1}$ Zirconium, articles thereof, waste or scrap

$2,313 \quad 942$ Manganese, articles thereof, waste or scrap

3,284943 Metals nes, articles, waste or scrap

$4,902 \quad 944$ Cermets and articles thereof, waste or scrap

$4,568 \quad 945$ Hand tools for agriculture, horticulture, forestry

$9,525 \quad 946$ Hand saws and blades for saws of all kinds

6,223947 Files, pliers, pincers, metalwork shears, etc

949 Hand

3,061949 Hand tools nes, anvils, clamps

$2,696 \quad 951$ Interchangeable tools and dies for hand or power tools

4,371
652
6 Knives, cutting blades, for machines and appliances

953 Tool plates, tips, etc, sintered metal carbide, cermel
7,890 Hand-operated appliances, food preparation, < $10 \mathrm{~kg}$

$9,749 \quad 955$ Knives and blades for hand use

7,205

$4,046 \quad 956$ Razors and razor blades (including blanks in strips)

$8,454 \quad 958$ Cutlery nes, cleavers, mincers, office, toilet items

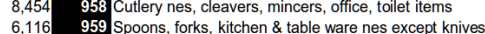

$\mathbf{5}, 710 \quad \mathbf{9 6 0}$ Padlocks, locks, clasps with locks, keys
6.

6,395 961 Base metal fittings nes for furniture, doors, cars/etc

10,632 962 Safes, strong-boxes etc, of base metal

10,098963 Office equipment of base metal eg filing cabinet, tray

11,665964 Office staples, binder fittings, paper clips etc.

$9,787 \quad 965$ Base metal bells, omaments, pictures, mirror frames

$5,127 \quad 966$ Flexible tubing of base meta

6,231967 Clasp, buckle, eye, etc for clothing, footwear, bags

968 Stoppers, caps, lids, crown corks, etc off base metal

969 Non-lluminated base metal sign plates, leter, numb

4,371970 Wire, rod, etc of base metal, carbide for welding etc
6019
$\mathbf{9 7 1}$ Nuclear reactors, fuel elements, isotope separators

5,034972 Steam/vapour generating boiler(except central heating)

3,308 973 Central heating boilers except steam generators

5,118974 Auxiliary plant for boilers

3,522 975 Producer, water and acetylene gas generators

$6,831 \quad 976$ Steam turbines and other vapour turbines

207978 Compression-ignition engines (diesel etc)

6,373
$6 \mathbf{9}$ $\mathbf{9 8 0}$ Parts for internal combustion spark ignition engines

8932981 Turbo-jets, turbo wapelers/other

$9,152 \quad 982$ Engines and motors, nes

7,845 983 Pumps for liquids.

5,981984 Air, vacuum pumps, compressors, ventilating fans, eto

$3,959 \quad 985$ Air conditioning equipment, machinery

4,849 986 Furnace burners, equipment, liquid, powder or gas fuel

4,068 989 Machinery, non-domestic, involving heating or cooling

12,816 995 Pulley tackle, hoists, winches, capstans and jacks

12,758 996 Derricks, cranes, straddle carriers, crane trucks 


\begin{tabular}{|c|c|c|c|c|c|c|c|}
\hline \multicolumn{2}{|r|}{ Produto } & \multicolumn{2}{|c|}{ PRODYX PRODYM } & \multirow{2}{*}{\multicolumn{2}{|c|}{$\begin{array}{l}\text { Produto } \\
1166 \text { Hydrometers, thermometers, barometers, etc }\end{array}$}} & \multirow{2}{*}{\multicolumn{2}{|c|}{ PRODYX PRODYM }} \\
\hline & Chain and parts thereof, of iron or steel & 14,172 & 6,736 & & & & \\
\hline 858 & Anchors, grapnels and parts thereof, of iron or steel & 9,194 & 6,450 & 1167 & Equipment to measure fluid flow, level, pressure, etc & 20,699 & 8,755 \\
\hline 859 & Nails, staples, etc, iron/steel, not office stationary & 4,587 & 4,851 & 1168 & Equipment for physical and chemical analysis & 16,635 & 10,706 \\
\hline 860 & Screws, bolts, nuts, rivets, washers, etc, iron, steel & 15,810 & 8,431 & 1169 & Gas, liquid or electricity supply or production meters & 10,062 & 4,107 \\
\hline 861 & Sewing, knitting needles, etc, hand use, iron or steel & 14,687 & 6,462 & 1170 & Revolution counters, taximeters, speedometers, etc & 17,538 & 12,551 \\
\hline 862 & Springs and leaves for springs, of iron or steel & 13,049 & 8,961 & 1171 & Instruments to check or measure electricity, radiation & 18,843 & 11,019 \\
\hline 863 & Stoves, ranges/barbecues,etc, non-electric, iron/steel & 7,500 & 6,476 & 1172 & Measuring or checking instruments nes & 19,744 & 11,892 \\
\hline 864 & Radiators, non-electric heaters (with fan), iron/steel & 13,585 & 10,973 & 1173 & Automatic regulating or controlling equipment & 17,473 & 10,518 \\
\hline 865 & Table, kitchen, household items of iron or steel nes & 6.715 & 7,152 & 1174 & Parts, accessories nes for opto-electric instruments & 15,192 & 8.855 \\
\hline 866 & Sanitary ware and parts thereof, of iron or steel & 11,048 & 7,298 & 1175 & Watches with case of, or clad with, precious metal & 5,488 & 13,190 \\
\hline 867 & Cast articles, of iron or steel nes & 10,540 & 9,642 & 1176 & Watches with case of, or clad with, of base metal & 7,419 & 13,783 \\
\hline 868 & Articles of iron or steel nes & 12,457 & 8,309 & 1177 & Clocks with watch movements, except vehicle panel & 19,298 & 7,164 \\
\hline 869 & Copper mattes, cement copper (precipitated copper) & 4,339 & 586 & 1178 & Instrument panel clocks etc for vehicles, aircraft etc & 14,279 & 4,496 \\
\hline 870 & Unrefined copper, copper anodes, electrolytic refining & 2,951 & 13,224 & 1179 & Other docks & 19,090 & 11,185 \\
\hline 871 & Refined copper and copper alloys, unurought & 3,318 & 3,621 & 1180 & Time of day recorders, time registers, etc & 16,819 & 10,883 \\
\hline 872 & Copper, copper alloy, waste or scrap & 6,861 & 13,199 & 1181 & Time switches & 12,872 & 11,043 \\
\hline 873 & Master alloys of copper & 11,405 & 12,342 & 1182 & Watch movements, complete and assembled & 21,987 & 4,023 \\
\hline 874 & Copper powders and flakes & 7,643 & 10,715 & 1183 & Clock movements, complete and assembled & 20,329 & 11,159 \\
\hline 875 & Copper bars, rods and profiles & 8,522 & 8,124 & 1184 & Watch and clock movements not fully assembled, etc & 15,054 & 6,332 \\
\hline 876 & Copper wire & 4,531 & 6,981 & 1185 & Watch cases and parts thereof & 16,720 & 5,886 \\
\hline 877 & Copper plates, sheets and strips, thickness $>0.15 \mathrm{~mm}$ & 2,244 & 9,813 & 1186 & Clock cases, cases of a similar type & 18,113 & 13,801 \\
\hline 878 & Copper foil, thickness (except any backing) $<0.15 \mathrm{~mm}$ & 15,911 & 12,444 & 1187 & Watch straps, bands, bracelets, and parts thereof & 11,242 & 6.425 \\
\hline 879 & Copper pipes, tubes & 11,660 & 9,475 & 1188 & Other dock or watch parts & 15,247 & 14,837 \\
\hline 880 & Copper pipe and tube fittings & 16,385 & 12,253 & 1189 & Pianos, harpsichords, keyboard string instruments nes & 12,417 & 14,978 \\
\hline 881 & Stranded copper wire, cable, plaits, etc, uninsulated & 1,617 & 4,605 & 1190 & Other string musical instruments & 10,470 & 12,620 \\
\hline 882 & Copper wire cloth, grill, netting, expanded metal & 13,686 & 7,047 & 1191 & Harmoniums, pipe organs, etc & 14,200 & 5,613 \\
\hline 883 & Copper nails, screws, bolts, pins, washers, etc & 16.851 & 8.050 & 1192 & Accordions and similar instruments, mouth organs & 10,224 & 14,478 \\
\hline 884 & Copper springs & 21,941 & 13,044 & 1193 & Wind musical instruments nes (brass, wood, bagpipes) & 17,043 & 14,880 \\
\hline 885 & Copper cooking, heating apparatus, non-electric, parts & 12,328 & 8,575 & 1194 & Percussion musical instruments & 4,384 & 11,747 \\
\hline 886 & Copper table, kitchen, household and sanitary items & 8,925 & 11,104 & 1195 & Musical instruments electrical, requiring amplifier & 6,566 & 11,543 \\
\hline 887 & Articles of copper nes & 12,096 & 10,619 & 1196 & Musical boxes, musical instruments etc, nes & 7,601 & 9,440 \\
\hline 888 & Nickel matte, interim products of nickel metallurgy & 9,628 & 7,024 & 1197 & Parts and accessories for musical instruments & 15,271 & 13,657 \\
\hline 889 & Unwrought nickel & 10,841 & 17.518 & 1198 & Military weapons, other than hand guns, swords, etc & 2.869 & 4.521 \\
\hline 890 & Nickel waste or scrap & 14,062 & 25,797 & 1199 & Revolvers and pistols & 4,019 & 5,953 \\
\hline 891 & Nickel powders and flakes & 14,140 & 18,499 & 1200 & Other firearms, sporting, etc, signal pistols, etc & 9,801 & 8,685 \\
\hline 892 & Nickel bars, rods, profiles and wire & 11,234 & 14,995 & 1201 & Arms nes, (spring, air or gas guns, truncheons, etc) & 15,960 & 8,144 \\
\hline 893 & Nickel plates, sheets, strip and foil & 13,190 & 14,192 & 1202 & Parts and accessories of weapons & 23,455 & 9,883 \\
\hline 894 & Nickel tubes, pipes and tube or pipe fittings & 28,705 & 12,756 & 1203 & Bombs, grenades, mines, missiles, ammunition, etc & 8,067 & 7,984 \\
\hline 895 & Articles of nickel, nes & 17,707 & 9,685 & 1204 & Swords, cutlasses, bayonets, lances, scabbards, etc & 5,544 & 8,204 \\
\hline 896 & Unwrought aluminium & 9,759 & 13,710 & 1205 & Seats (except dentist, barber, etc chairs) & 9,077 & 13,117 \\
\hline 897 & Aluminium waste or scrap & 5,639 & 8,704 & 1206 & Medical, dental, surgical, veterinary furniture, parts & 14,448 & 5,893 \\
\hline 898 & Aluminium powders and flakes & 15,642 & 7,859 & 1207 & Other furmiture and parts thereof & 6,784 & 9,903 \\
\hline 899 & Aluminium bars, rods and profiles & 10,892 & 9,841 & 1208 & Mattress supports, mattresses, bedding & 6,690 & 10,362 \\
\hline 900 & Aluminium wire & 8,945 & 6.076 & 1209 & Lamps and lighting fittings, illuminated signs, etc & 11,358 & 10,075 \\
\hline 901 & Aluminium plates, sheets and strip, thickness $>0.2 \mathrm{~mm}$ & 11,634 & 9,632 & 1210 & Prefabricated buildings & 12,573 & 7,549 \\
\hline 902 & Aluminium foil of a thickness $<0.2 \mathrm{~mm}$ & 18,218 & 6,230 & 1211 & Rideable wheeled toys, dolls carriages & 9,291 & 9,380 \\
\hline 903 & Aluminium tubes and pipes & 10,969 & 9,697 & 1212 & Dolls representing only human beings & 13,576 & 11,711 \\
\hline 904 & Aluminium tube or pipe fittings & 11,507 & 7,979 & 1213 & Other toys, scale models, puzzles, etc & 13,746 & 12,839 \\
\hline 905 & Aluminium structures, parts nes, for construction & 7,910 & 7,857 & 1214 & Articles for funfairs, table and parlour games & 18,868 & 16,006 \\
\hline 906 & Aluminium reservoirs, vats, tanks, etc, capacity $>300 \mid$ & 10,075 & 7,068 & 1215 & Festive, camival and other entertainment artides & 10,948 & 12,727 \\
\hline 907 & Aluminium casks, drums, boxes, etc. capacity $<3001$ & 9,024 & 7,347 & 1216 & Equipment for gymnastics, sports, outdoor games nes & 11,304 & 13,579 \\
\hline 908 & Aluminium containers for compressed or liquefied gas & 3,016 & 8,862 & 1217 & Fishing and hunting equipment, requisites nes & 7,396 & 8,076 \\
\hline 909 & Aluminium stranded wire, cables, plaits, uninsulated & 6,414 & 5,191 & 1218 & Play, fair-ground equipment, travellng circus, theatre & 8,193 & 8,966 \\
\hline 910 & Aluminium ware for table, kitchen, sanitary use & 8,959 & 7,114 & 1219 & Worked ivory, other animal carving material & 2,185 & 10,627 \\
\hline 911 & Articles of aluminium nes & 11,094 & 8,939 & 1220 & Worked vegetable, mineral carving material, articles & 4,659 & 6,509 \\
\hline 912 & Unwrought lead & 6,569 & 8,161 & 1221 & Brooms, brushes, mops, feather dusters, paint pads etc & 8.533 & 8,116 \\
\hline 913 & Lead waste or scrap & 3,819 & 12,797 & 1222 & Hand sieves and hand riddles & 10,243 & 2,842 \\
\hline 914 & Lead bars, rods, profiles and wire & 4,931 & 3,584 & 1223 & Travel sets, toilet, sewing, shoe, clothes deaning & 2,045 & 6,234 \\
\hline 915 & Lead plates, sheets, strip, foil, powders and flakes & 10,083 & 10,979 & 1224 & Buttons, press and snap fasteners, etc & 8,467 & 4,366 \\
\hline 916 & Lead tubes, pipes and fittings & 9,417 & 2,076 & 1225 & Slide fasteners and parts thereof & 6,463 & 4,085 \\
\hline 917 & Articles of lead nes & 7,896 & 5,160 & 1226 & Pens (writing), mechanical pencils, parts & 13,033 & 7,156 \\
\hline 918 & Unwrought zinc & 8,337 & 6,612 & 1227 & Pencils (ordinary), pencil leads, chalks, pastels etc & 6,157 & 5,340 \\
\hline 919 & Zinc waste or scrap & 9,095 & 9,130 & 1228 & Slates and boards with writing or drawing surfaces & 8,234 & 6,094 \\
\hline 920 & Zinc dust, powders and flakes & 9,846 & 5,889 & 1229 & Hand printing, dating and numbering devices, etc & 6,368 & 7,942 \\
\hline 921 & Zinc bars, rods, profiles and wire & 2,981 & 5,362 & 1230 & Typewriter and similar ribbons, ink pads, etc & 14,937 & 7,895 \\
\hline 922 & Zinc plates, sheets, strip and foil & 6,001 & 5,665 & 1231 & Cigarette and other lighters, lighter parts & 11,462 & 8,187 \\
\hline 923 & Zinc tubes, pipes and tube or pipe fittings & 12,609 & 9,087 & 1232 & Smoking pipes, cigar and cigarette holders, parts & 4,324 & 10,848 \\
\hline 924 & Articles of zinc nes & 14,204 & 5,255 & 1233 & Combs, hair slides, pins and similar omaments & 13,236 & 7,496 \\
\hline 925 & Unwrought tin & 2,509 & 10,722 & 1234 & Scent, toilet sprays, puffs and pads for cosmetics & 13,688 & 7,168 \\
\hline 926 & Tin waste or scrap & 10,810 & 7,297 & 1235 & Vacuum flasks etc, parts thereof except inner & 5,770 & 5.448 \\
\hline 927 & Tin bars, rods, profiles and wire & 8,852 & 8,438 & 1236 & Tailors dummies, display dummies and automata & 7,494 & 11,760 \\
\hline 928 & Tin plates, sheets and strips, thickness $>0.2 \mathrm{~mm}$ & 9,699 & 2,333 & 1237 & Paintings, drawings, pastels, collages etc, hand made & 20,131 & 11,568 \\
\hline 929 & Tin foil (thickness $<0.2 \mathrm{~mm}$ ), tin powder, flakes & 20,066 & 11,865 & 1238 & Original engravings, prints and lithographs & 24,123 & 21,820 \\
\hline 930 & Tin pipes or tubes and pipe fittings & 11,677 & 4,354 & 1240 & Original sculptures and statuary, in any material & 8,483 & 17,580 \\
\hline 931 & Tin articles nes & 4,707 & 4,89 & 1241 & Used postage and revenue stamps, first day covers, etc & 23,885 & 20,729 \\
\hline 932 & Tungsten (wolfram) and articles, waste or scrap & 17,729 & 10,987 & 1242 & Collections and collectors pieces & 7,159 & 19,032 \\
\hline 933 & Molybdenum and articles thereof, waste or scrap & 2,230 & 11,971 & 1243 & Antiques older than one hundred years & 13,288 & 26,557 \\
\hline & & & & 1244 & Commodities not elsewhere specified & 14,651 & 8,331 \\
\hline
\end{tabular}




\section{ANEXO C - Lista de países, EXPY e IMPY}

\begin{tabular}{|c|c|c|c|c|c|c|c|}
\hline \multicolumn{8}{|c|}{ LISTA DE PAISES - EXPY \& IMPY (2005) } \\
\hline & & EXPY & IMPY & & & EXPY & IMPY \\
\hline & Albânia & 5,137 & 6,366 & 73 & Lituânia & 8,445 & 8,315 \\
\hline 2 & Argélia & 7,238 & 7,070 & 74 & Luxemburgo & 11,314 & 8,856 \\
\hline & Argentina & 7,325 & 8,590 & 75 & Macau, China, & 7,366 & 9,342 \\
\hline 4 & Armênia & 5,622 & 7,949 & 76 & Madagascar & 5,390 & 5,850 \\
\hline 5 & Austrália & 8,393 & 8,968 & 77 & Malawi & 1,798 & 4,739 \\
\hline 6 & Áustria & 12,294 & 9,012 & 78 & Malásia & 9,731 & 8,425 \\
\hline & Azerbeijão & 6,068 & 6,995 & 79 & Maldivas & 5,816 & 6,804 \\
\hline 8 & Bahrein & 7,188 & 8,697 & 80 & Mali & 2,027 & 4,984 \\
\hline 9 & Bangladesh & 4,768 & 5,541 & 81 & Malta & 10,626 & 9,066 \\
\hline 10 & Bielorrússia & 8,060 & 7,938 & 82 & Mauritânia & 4,404 & 3,848 \\
\hline 11 & Bélgica & 11,915 & 9,286 & 83 & Maurícia & 7,146 & 7,056 \\
\hline 12 & Belize & 3,706 & 6,725 & 84 & México & 10,727 & 8,809 \\
\hline 13 & Benin & 2,088 & 5,327 & 85 & Moldávia & 5,674 & 6,703 \\
\hline 14 & Butāo & 5,053 & 6,514 & 86 & Mongólia & 3,247 & 6,120 \\
\hline 15 & Bolívia & 6,072 & 6,560 & 87 & Marrocos & 5,557 & 7,425 \\
\hline 16 & Bósnia e Herzegovina & 7,974 & 7,396 & 88 & Moçambique & 7,720 & 6,792 \\
\hline 17 & Botsuana & 7,195 & 7,144 & 89 & Namíbia & 6,495 & 7,471 \\
\hline 18 & Brasil & 8,409 & 8,655 & 90 & Holanda & 12,016 & 9,242 \\
\hline 19 & Bulgária & 7,859 & 7,936 & 91 & Nova Zelândia & 7,916 & 8,590 \\
\hline 20 & Burkina Faso & 1,644 & 5,596 & 92 & Nicarágua & 3,933 & 6,958 \\
\hline 21 & Burundi & 1,787 & 6,074 & 93 & Niger & 4,103 & 5,185 \\
\hline 22 & Camarões & 6,119 & 6,821 & 94 & Noruega & 8,251 & 8,992 \\
\hline 23 & Canadá, & 11,048 & 9,156 & 95 & Omã & 7,089 & 7,885 \\
\hline 24 & Cabo Verde & 6,118 & 6,384 & 96 & Paquistão & 4,987 & 6,979 \\
\hline 25 & Chile & 5,464 & 8,040 & 97 & Panamá & 5,650 & 7,391 \\
\hline 26 & China & 10,971 & 9,403 & 98 & Paraguai & 4,489 & 7,523 \\
\hline 27 & Colômbia & 6,922 & 7,965 & 99 & Peru & 4,765 & 7,411 \\
\hline 28 & Costa Rica & 9,858 & 8,419 & 100 & Filipinas & 11,593 & 9,495 \\
\hline 29 & Costa Marfim & 4,292 & 6,453 & 101 & Polónia & 10,448 & 8,418 \\
\hline 30 & Croácia & 9,408 & 8,374 & 102 & Portugal & 10,529 & 8,649 \\
\hline 31 & Chipre & 11,095 & 7,971 & 103 & Roménia & 8,261 & 8,001 \\
\hline 32 & República Checa & 12,056 & 8,878 & 104 & Rússia & 8,053 & 8,206 \\
\hline 33 & Dinamarca & 10,361 & 8,994 & 105 & Ruanda & 2,086 & 6,213 \\
\hline 34 & Dominica & 5,602 & 6,689 & 106 & Samoa & 5,163 & 6,541 \\
\hline 35 & Equador & 5,635 & 6,644 & 107 & São Tomé e Príncipe & 973 & 5,380 \\
\hline 36 & El Salvador & 6,191 & 7,142 & 108 & Arábia Saudita & 6,660 & 8,084 \\
\hline 37 & Estônia & 10,252 & 8,304 & 109 & Senegal & 5,860 & 6,040 \\
\hline 38 & Etiópia & 1,658 & 6,238 & 110 & Sérvia & 8,291 & 7,908 \\
\hline 39 & Fiji & 5,154 & 6,505 & 111 & Seychelles & 6,440 & 6,846 \\
\hline 40 & Finlândia & 13,192 & 9,195 & 112 & Cingapura & 13,186 & 10,037 \\
\hline 41 & França & 12,257 & 9,266 & 113 & Eslovaca & 10,982 & 8,652 \\
\hline 42 & Gabão & 5,817 & 7,067 & 114 & Eslovénia & 12,317 & 8,562 \\
\hline 43 & Gâmbia & 4,005 & 5,455 & 115 & Ilhas Salomão & 2,086 & 6,151 \\
\hline 44 & Geórgia & 6,110 & 7,013 & 116 & África & 9,178 & 8,845 \\
\hline 45 & Alemanha & 13,239 & 9,462 & 117 & Espanha & 11,382 & 9,060 \\
\hline 46 & Gana & 2,832 & 6,527 & 118 & Sri Lanka & 5,176 & 6,737 \\
\hline 47 & Grécia & 9,167 & 8,635 & 119 & São Cristóvão e Névis & 9,654 & 7,616 \\
\hline 48 & Granada & 5,822 & 7,082 & 120 & St. Lucia & 7,155 & 7,380 \\
\hline 49 & Guatemala & 5,935 & 6,684 & 121 & São Vicente e Granadinas & 5,107 & 6,685 \\
\hline 50 & Guiné & 2,021 & 6,902 & 122 & Sudão & 5,844 & 6,313 \\
\hline 51 & Guiné-Bissau & 372 & 4,454 & 123 & Suazilândia & 6,855 & 6,524 \\
\hline 52 & Guiana & 3,821 & 5,839 & 124 & Suécia & 13,430 & 9,269 \\
\hline 53 & Honduras & 4,025 & 7,544 & 125 & Suiça & 13,689 & 10,029 \\
\hline 54 & China & 12,188 & 10,635 & 126 & Síria & 6,067 & 6,529 \\
\hline 55 & Hungria & 12,004 & 8,939 & 127 & Tanzânia & 3,300 & 6,130 \\
\hline 56 & Islândia & 9,194 & 8,545 & 128 & Tailândia & 10,455 & 8,920 \\
\hline 57 & Índia & 8,020 & 8,761 & 129 & Timor-Leste & 6,909 & 5,957 \\
\hline 58 & Indonésia & 7,858 & 7,226 & 130 & Togo & 3,926 & 5,436 \\
\hline 59 & Iram & 6,558 & 7,073 & 131 & Trinidad e Tobago & 7,531 & 7,905 \\
\hline 60 & Irlanda & 13,746 & 9,740 & 132 & Tunisia & 6,772 & 7,026 \\
\hline 61 & Israel & 10,403 & 9,852 & 133 & Turquia & 8,753 & 8,377 \\
\hline 62 & Itália & 11,653 & 9,155 & 134 & Uganda & 4,861 & 5,943 \\
\hline 63 & Jamaica & 4,630 & 6,711 & 135 & Ucrânia & 7,771 & 7,869 \\
\hline 64 & Јapão & 14,153 & 9,921 & 136 & Emirados Árabes & 9,703 & 9,287 \\
\hline 65 & Jordânia & 7,455 & 7,464 & 137 & Reino Unido & 12,708 & 9,547 \\
\hline 66 & Cazaquistão & 6,045 & 7,183 & 138 & EUA & 12,922 & 9,608 \\
\hline 67 & Quênia & 5,194 & 6,940 & 139 & Uruguai & 6,756 & 7,855 \\
\hline 68 & Kiribati & 2,532 & 5,527 & 140 & Venezuela & 6,397 & 8,077 \\
\hline 69 & Coréia & 12,995 & 9,405 & 141 & Vietnā & 6,241 & 6,791 \\
\hline 70 & Quirguistão & 4,857 & 6,218 & 142 & Iêmen & 6,154 & 5,412 \\
\hline 71 & Letônia & 8,502 & 7,798 & 143 & Zâmbia & 3,286 & 5,853 \\
\hline 72 & $\begin{array}{l}\text { Libano } \\
\text { Lib }\end{array}$ & 7,859 & 7,245 & 144 & Zimbábue & 3,551 & 5,239 \\
\hline
\end{tabular}




\section{ANEXO D - Resultados do Teste de Hausman}

\begin{tabular}{|c|c|c|c|c|}
\hline \multicolumn{5}{|c|}{ Teste de Hausmam } \\
\hline & $\bar{b}$ & $\overline{\mathrm{B}}$ & $\mathrm{b}-\mathrm{B}$ & $\overline{\mathrm{DP}}$ \\
\hline EXPY & -.2853996 & 2287748 & -.5141744 & 1162979 \\
\hline Cap Físico & 75.89795 & -37.46057 & 113.3585 & 54.27991 \\
\hline Cap Humano & 297.1676 & 274.6182 & 22.54939 & 22.81371 \\
\hline Instituições & -65.54442 & -98.56535 & 33.02094 & 12.28473 \\
\hline Trabalho & .0000878 & .0000667 & .000021 & $5.21 \mathrm{e}-06$ \\
\hline & \multicolumn{4}{|c|}{$\begin{array}{l}b=\text { Menos Eficiente }- \text { Efeito Fixo } \\
B=\text { Eficiente }- \text { Efeito Aleatorio }\end{array}$} \\
\hline Teste: Ho: & \multicolumn{4}{|c|}{ diferença entre coeficientes e nao sistematica } \\
\hline & \multicolumn{4}{|c|}{$\operatorname{chi} 2(4)=(b-B)^{\prime}\left[\left(V \_b-V \_B\right)^{\wedge}(-1)\right](b-B)$} \\
\hline & \multicolumn{4}{|c|}{$\begin{aligned} 31.98 & \\
& \end{aligned}$} \\
\hline
\end{tabular}

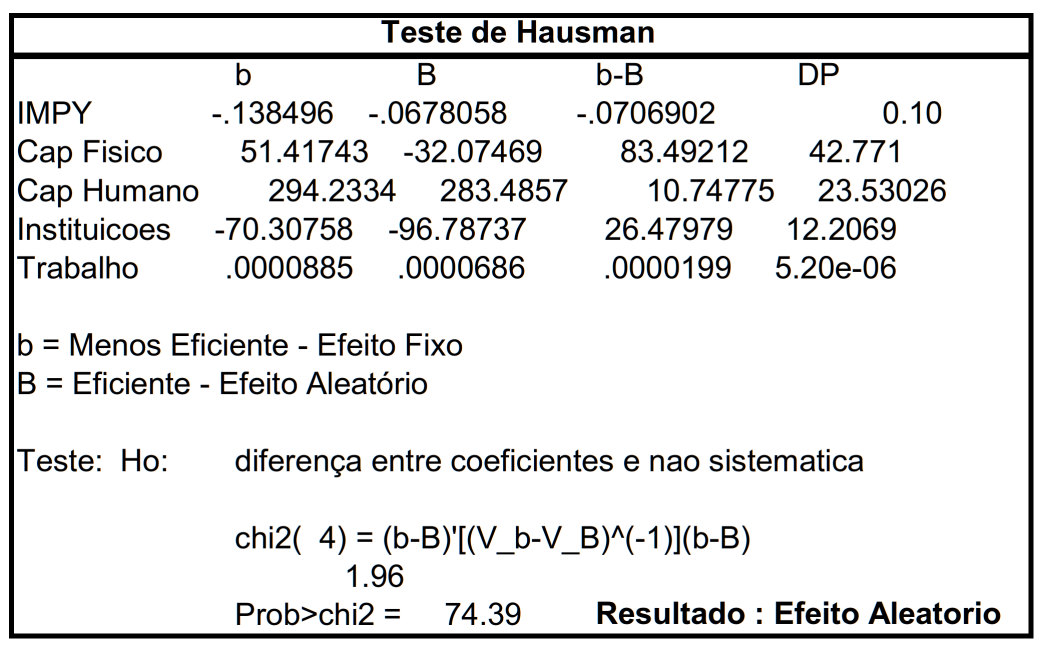




\section{ANEXO E - Modelo teórico da Estimação por Efeito Fixo, Efeito Aleatório e Teste de Hausman}

A exposição neste Anexo é baseada em Woodridge (2004).

\section{E.1 Efeito Fixo ou Mínimos Quadrados Ordinários (MQO) com variáveis dummy}

O estimador de efeitos fixos pode ser aplicado ao seguinte modelo:

$$
y_{i t}=X_{i t} \beta+C_{i}+\mu_{t}
$$

Quando temos $E\left(C_{i} / X_{i}\right) \neq 0$, ou seja o efeito específico $C_{i}$ é correlacionado com $X_{i t}$, o estimador de MQO é inconsistente. Assim, precisamos eliminar o efeito específico para estimar $\beta$. Uma opção é o estimador de efeito fixo:

$$
\begin{gathered}
X_{i t}=X_{i t}-E\left(X_{i t}\right) \\
y_{i t}=y_{i t}-E\left(y_{i t}\right) \\
C_{i}-E\left(C_{i}\right)=0 \\
\mu_{i t}=\mu_{i t}-E\left(\mu_{i t}\right)
\end{gathered}
$$

Temos que:

$$
y_{i t}=X_{i t} \beta+\mu_{i t}
$$

Como na expressão acima temos $E\left(\mu_{i t} / x_{i t}\right)=0$, podemos aplicar MQO:

$$
\beta_{e f}=\left(\sum_{i} X_{i}^{\prime} X_{i}\right)^{-1}\left(\sum_{i} X_{i}^{\prime} y_{i}\right) .
$$


Outro modo de fazer a estimação por efeito fixo é, ao invés de construir $X_{i t}$, que capta o desvio em relação à média do indivíduo, colocar uma dummy para cada indivíduo - MQO com dummy de indivíduo. Dessa maneira, o $\beta$ obtido é igual ao obtido através do procedimento anterior, com a vantagem, porém, de que podemos estimar $C_{i}$. No presente artigo, vale ressaltar, a estimação do efeito especifico é importante.

\section{E.2 Efeito Aleatório}

No caso do efeito aleatório, temos o seguinte modelo:

$$
y_{i t}=X_{i t} \beta+C_{i}+\mu_{t}
$$

Entretanto, $E\left(C_{i} / X_{i}\right)=0$, de maneira que o efeito específico não é correlacionado com $X_{i}$ e, portanto, o estimador de MQO ainda é consistente. No entanto, este estimador terá um problema de ineficiência pois existe uma autocorrelação dos resíduos entre as observações do mesmo indivíduo devido à presença de $C_{i}$. Assim, o melhor método de estimação é o de Mínimos Quadrados Generalizados (MQG), que corrige a autocorrelação. Logo, temos que o estimador de efeito aleatório é dado por

$$
\beta_{e a}=\left(\sum X_{i}^{\prime} \Omega e^{-1} X_{i}\right)^{-1}\left(\sum X_{i}^{\prime} \Omega e^{-1} y_{i}\right)
$$

onde $\Omega$ é a matriz de variância e covariância dos resíduos.

\section{E.3 Teste de Hausman}

O teste de Hausmam pode ser utilizado para comparar dois estimadores. No caso do presente artigo, trata-se de comparar os estimadores de efeito fixo e aleatório:

$$
H=\left(\beta_{e f}-\beta_{e a}\right)^{\prime}\left(A \operatorname{var}\left(\beta_{e f}\right)-A \operatorname{var}\left(\beta_{e a}\right)\right)^{-1}\left(\beta_{e f}-\beta_{e a}\right) \sim X^{2},
$$

onde $H_{0}=E\left(C_{i} / X_{i}\right)=0$.

Portanto, se $H$ for estatisticamente próximo de zero, aceita-se $H_{0}$ e, portanto, deve-se utilizar o estimador de efeito aleatório. Por outro lado, se $H$ for estatisticamente próximo de zero, rejeita-se $H_{0}$ e, portanto, como o termo específico tem correlação com $X_{i}$, deve-se utilizar o estimador de efeito fixo. Neste artigo, também utilizaremos esse teste para avaliar o modelo pooled, ou seja, aquele que desconsidera tanto o efeito específico como o efeito fixo. 


\section{ANEXO F - Resultados Teste de Hausman - Ensaio II}

\section{F.1 Período 1980-2004}

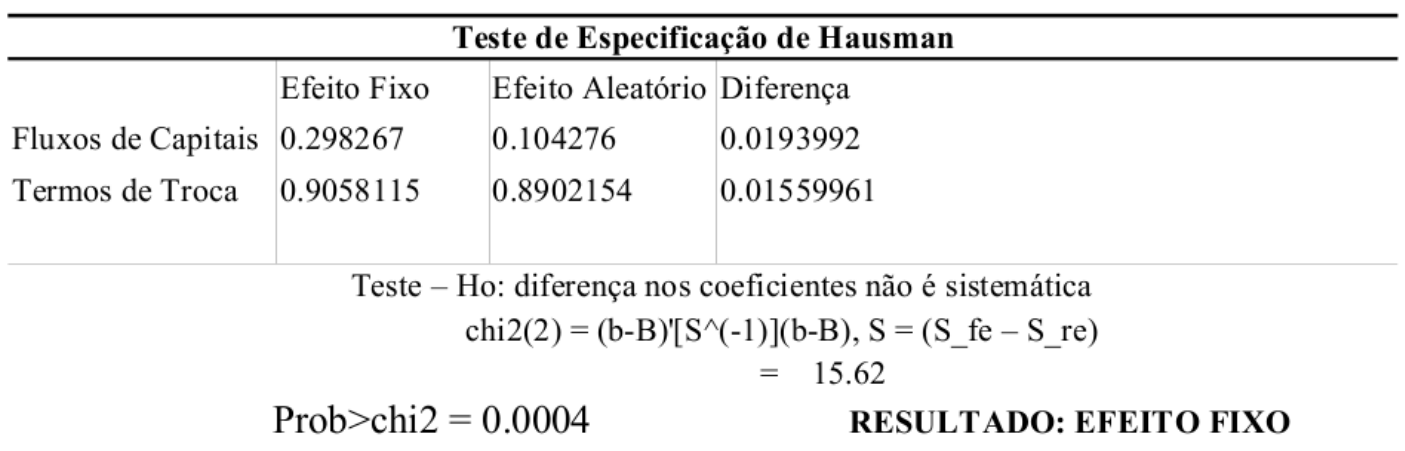

\section{F.2 Período 2000-2008}

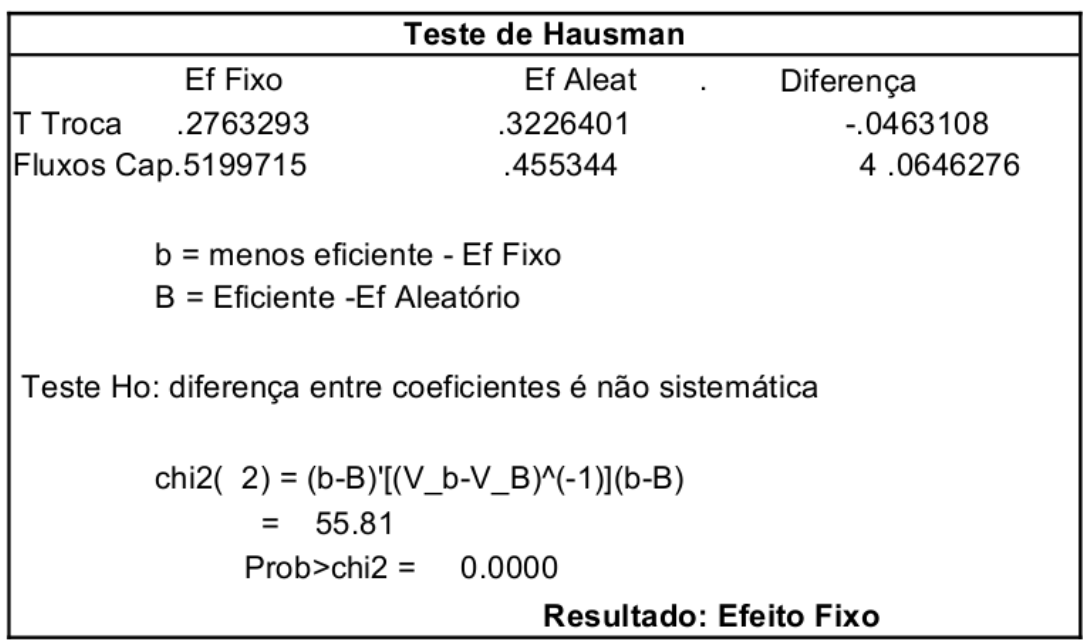




\section{ANEXO G - Elasticidade-renda das importações para o período 1980-2004}

\begin{tabular}{|c|c|c|c|c|c|}
\hline País & Elast Import & País & Elast Import & País & Elast Import \\
\hline África Central & 1,91 & Etiopía & 1,46 & México & 1,24 \\
\hline África do Sul & 1,27 & Fiji & 1,28 & Moldávia & 1,56 \\
\hline Albânia & 1,03 & Filipinas & 1,3 & Moçambique & 1,66 \\
\hline Angola & 2,1 & Finlandia & 1,12 & Namíbia & 1,56 \\
\hline Antigua & 1,03 & França & 1,13 & Nepal & 1,23 \\
\hline Argélia & 1,19 & Gabão & 1,07 & Nicarágua & 1,73 \\
\hline Argentina & 1,25 & Gâmbia & 1,33 & Niger & 1,83 \\
\hline Austrália & 1,19 & Gana & 1,17 & Nigéria & 1,44 \\
\hline Áustria & 1,09 & Granada & 1,12 & Noruega & 1,07 \\
\hline Azerbaijão & 2,04 & Grécia & 1,13 & Nova Zelândia & 1,22 \\
\hline Bahrain & 1,24 & Guatemala & 1,27 & Panamá & 1,2 \\
\hline Bangladesh & 1,32 & Guiana & 1,15 & Paquistão & 1,1 \\
\hline Barbados & 0,93 & Guiné & 1,06 & Paraguai & 1,25 \\
\hline Bélgica & 1,13 & Guiné Eq. & 1,92 & Peru & 1,26 \\
\hline Belice & 1,09 & Guiné-Bissau & 1,15 & Polonia & 1,31 \\
\hline Benin & 1,39 & Haiti & 1,13 & Porto Rico & 1,14 \\
\hline Bolívia & 1,44 & Holanda & 1,16 & Portugal & 1,08 \\
\hline Botswana & 0,95 & Honduras & 1,47 & Reino Unido & 1,18 \\
\hline Brasil & 1,14 & Hong Kong & 0,96 & Rep. Checa & 1,51 \\
\hline Bulgária & 3,96 & Hungria & 1,16 & România & 1,14 \\
\hline Burquina Faso & 1,56 & Índia & 1,15 & Ruanda & 1,6 \\
\hline Burundi & 1,3 & Indonésia & 1,13 & Rússia & 1,71 \\
\hline Cabo Verde & 1,26 & Irã & 1,3 & São Tome & 1,14 \\
\hline Camarões & 1,38 & Irlanda & 1,12 & São Vincent & 1,11 \\
\hline Cambodia & 1,53 & Islândia & 1,15 & Senegal & 1,47 \\
\hline Canadá & 1,19 & Israel & 1,19 & Serra Leoa & 1 \\
\hline Cazaquistão & 1,02 & Itália & 1,1 & Seychelles & 1,43 \\
\hline Chade & 1,54 & Jamaica & 1,3 & Singapura & 0,99 \\
\hline Chile & 1,14 & Japão & 0,98 & Síria & 1,17 \\
\hline China & 1,03 & Jordânia & 1,66 & Sri Lanka & 1,15 \\
\hline Chipre & 1,05 & Quênia & 1,22 & St Lucia & 1,06 \\
\hline Colômbia & 1,2 & Coréia & 0,98 & Suécia & 1,18 \\
\hline Camarões & 1,83 & Kyrgyzstan & 1,08 & Suiça & 1,26 \\
\hline Rep. Congo & 0,99 & Laos & 1,31 & Tailândia & 0,99 \\
\hline Congo & 2,09 & Latvia & 4,33 & Tanzânia & 1,55 \\
\hline Costa do Marfim & 1,31 & Lesotho & 1,55 & Togo & 1,4 \\
\hline Costa Rica & 1,29 & Lithuania & 1,49 & Trinidad \&Tobago & 1,1 \\
\hline Croácia & 0,89 & Luxemburgo & 1,11 & Tunísia & 1,07 \\
\hline Dinamarca & 1,17 & Macau & 1,04 & Turquia & 1,26 \\
\hline Djibouti & 1,53 & Macedônia & 1,09 & Uganda & 1,13 \\
\hline Dominicana & 1,11 & Malásia & 1,03 & Uruguai & 1,26 \\
\hline Egito & 1,1 & Malaui & 1,23 & EUA & 0,94 \\
\hline El Salvador & 1,38 & Mali & 1,38 & Venezuela & 1,57 \\
\hline Equador & 1,2 & Malta & 0,81 & Vietnã & 1,2 \\
\hline Eslováquia & 1,47 & Marrocos & 1,15 & Yemen & 2,19 \\
\hline Eslovênia & 1,04 & Ilhas Maurício & 1,16 & Zâmbia & 1,17 \\
\hline Espanha & 1,1 & Mauritânia & 1,41 & Zimbabue & 1,25 \\
\hline
\end{tabular}




\section{ANEXO H - Análise de ajustamento e causalidade de Granger para renda e exportações - Brasil}

Quaisquer dúvidas em relação à análise em séries de tempo, VEC, variáveis de ajustamento e causalidade de Granger podem ser esclarecidos em Hamilton (1994) e Enders (2004).

\section{H.1 Testes ADF - 1 raiz unitária contra 0 raízes unitárias}

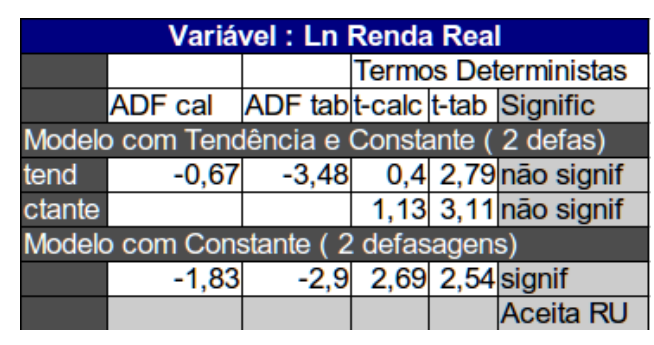

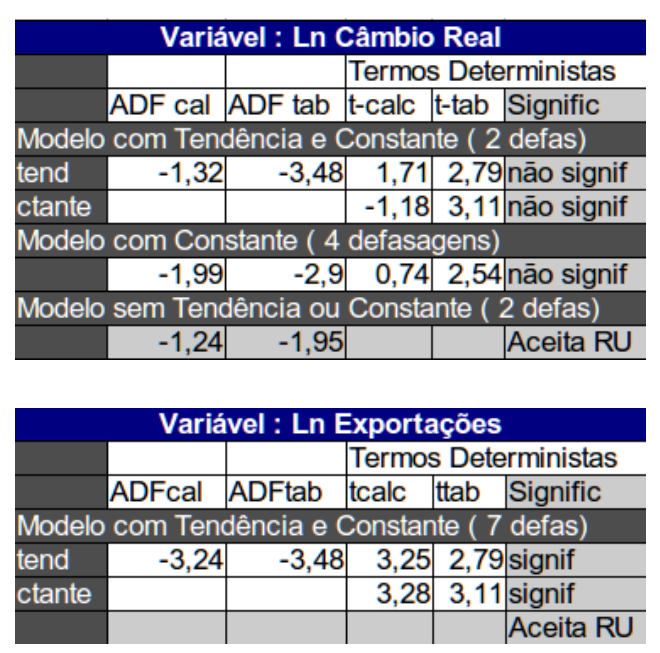




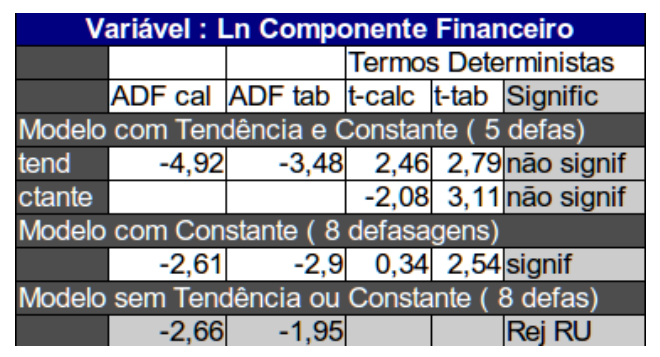

Obs: Valores críticos a 5\% de significância. Valores críticos dos termos deterministas para amostras de 100 observações.

Conclusão: Podemos aceitar a hipótese de 1 Raiz Unitária para as variáveis Importações, Exportações, Renda Interna, Importações Mundiais e Câmbio Real. Rejeitamos a hipótese de 1 RU para as variáveis exportações líquidas e componente financeiro, indicando que estas séries são estacionárias.

\section{H.2 Vetor de cointegração e testes de cointegração}

\section{Seleção da ordem VAR}

\begin{tabular}{|c|c|c|c|c|c|c|}
\hline \multicolumn{7}{|c|}{ VAR Lag Order Selection Criteria } \\
\hline \multicolumn{7}{|c|}{ Endogenous variables: LYR LX LFINM2 LER } \\
\hline \multicolumn{7}{|c|}{ Exogenous variables: $\mathrm{C}$} \\
\hline \multicolumn{7}{|c|}{ Sample: 19302004} \\
\hline \multicolumn{7}{|c|}{ Included observations: 69} \\
\hline Lag & $\log L$ & LR & FPE & AIC & $\mathrm{SC}$ & HQ \\
\hline 0 & -373.4111 & NA & 0.662292 & 10.93945 & 11.06896 & 10.99083 \\
\hline 1 & 26.15637 & 741.2266 & $9.84 \mathrm{E}-06$ & -0.178446 & $0.469122 *$ & $0.078466^{*}$ \\
\hline 2 & 43.26765 & $29.75874 *$ & $9.58 \mathrm{E}-06^{*}$ & -0.210656 & 0.954964 & 0.251784 \\
\hline 3 & 59.41920 & 26.21702 & $9.65 \mathrm{E}-06$ & $-0.215049^{*}$ & 1.468625 & 0.452920 \\
\hline 4 & 71.12552 & 17.64431 & $1.12 \mathrm{E}-05$ & -0.090595 & 2.111133 & 0.782904 \\
\hline 5 & 89.62905 & 25.74403 & $1.08 \mathrm{E}-05$ & -0.163161 & 2.556621 & 0.915868 \\
\hline 6 & 98.65546 & 11.51194 & $1.40 \mathrm{E}-05$ & 0.038972 & 3.276808 & 1.323530 \\
\hline \multicolumn{7}{|c|}{ *indicates lag order selected by the criterion } \\
\hline \multicolumn{7}{|c|}{ LR: sequential modified LR test statistic (each test at $5 \%$ level) } \\
\hline \multicolumn{7}{|c|}{ FPE: Final prediction error } \\
\hline \multicolumn{7}{|c|}{ AIC: Akaike information criterion } \\
\hline \multicolumn{7}{|c|}{ SC: Schwarz information criterion } \\
\hline \multicolumn{7}{|c|}{ HQ: Hannan-Quinn information criterion } \\
\hline
\end{tabular}

Conclusão: Os critérios de informação e o teste LR nos apresentaram informações contraditórias sobre a ordem do VAR a ser escolhido. Escolhemos então o critério FPE e LR (VEC 1), pois além de apresentar um número de defasagens intermediárias, nos permitirá fazer o teste de Casualidade de Granger, o que não seria possível se escolhêssemos um VEC 0 apontado pelo teste SC e HQ. 


\section{Escolha dos termos deterministas}

\begin{tabular}{|c|c|c|c|c|c|}
\hline \multicolumn{6}{|c|}{ Sample: 19302004} \\
\hline \multicolumn{6}{|c|}{ Included observations: 73} \\
\hline \multicolumn{6}{|c|}{ Series: LYR LX LFINM2 LER } \\
\hline \multicolumn{6}{|c|}{ Lags interval: 1 to 1} \\
\hline Data Trend: & None & None & Linear & Linear & Quadratic \\
\hline Rank or & No Intercept & Intercept & Intercept & Intercept & Intercept \\
\hline No. of CEs & No Trend & No Trend & No Trend & Trend & Trend \\
\hline \multicolumn{6}{|c|}{ Selected (5\% level) Number of Cointegrating Relations by Model (columns) } \\
\hline Trace & 2 & 1 & 0 & 0 & 0 \\
\hline Max-Eig & 2 & 1 & 0 & 0 & 0 \\
\hline
\end{tabular}

Pelos critérios tradicionais, escolheríamos o segundo modelo com constante dentro do vetor de cointegração, pois as variáveis tem unidades bastante diferenciadas e é o que nos indicaria o Principio de Pantula para obter ao menos 1 vetor de cointegração.

No entanto, pela especificação do modelo, forçaremos que não haja constante dentro do vetor de cointegração, pois desta forma imporíamos o equilíbrio do balanço de pagamentos no longo prazo. 


\section{Vetor de Cointegração e testes de Cointegração}

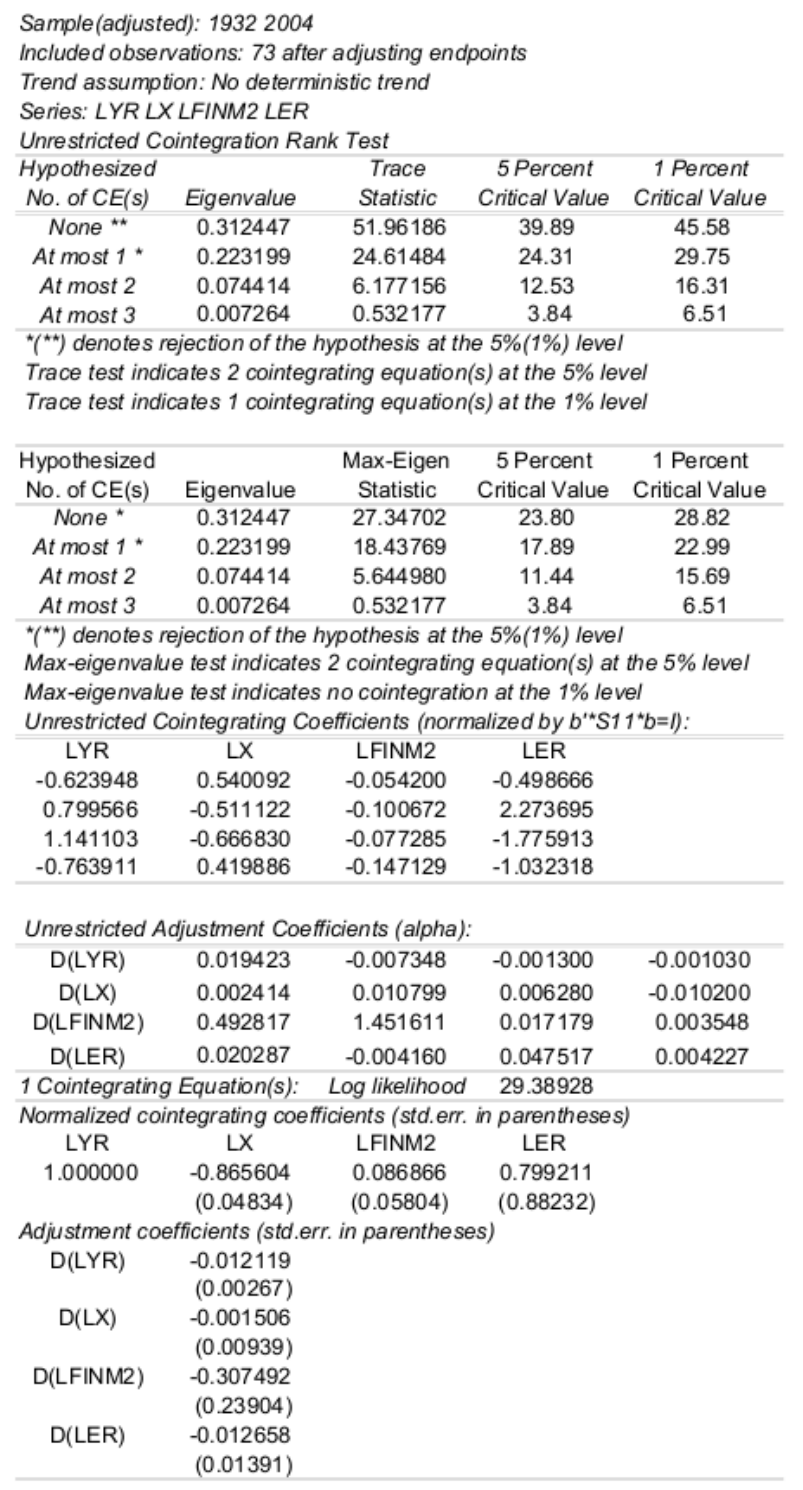

Vector Error Correction Estimates

Sample(adjusted): 19322004

Included observations: 73 after adjusting endpoints

Standard errors in () \& t-statistics in []

Cointegrating Eq: $\quad$ CointEq1

$\begin{array}{ll}\text { LYR(-1) } & 1.000000\end{array}$

$L X(-1) \quad-0.865604$
$(0.04834)$

[-17.9048]

LFINM2(-1) $\quad 0.086866$

$(0.05804)$

[ 1.49677]

\begin{tabular}{ccccc} 
LER(-1) & 0.799211 & & & \\
& $(0.88232)$ & & & \\
& {$[\mathbf{0 . 9 0 5 8 1}]$} & & & \\
\hline Error Correction: & $\mathrm{D}(\mathrm{LYR})$ & $\mathrm{D}(\mathrm{LX})$ & $\mathrm{D}(\mathrm{LFINM} 2)$ & $\mathrm{D}(\mathrm{LER})$ \\
\hline CointEq1 & $\mathbf{- 0 . 0 1 2 1 1 9}$ & -0.001506 & -0.307492 & -0.012658 \\
& $(0.00267)$ & $(0.00939)$ & $(0.23904)$ & $(0.01391)$ \\
& {$[-4.54669]$} & {$[-0.16050]$} & {$[-1.28634]$} & {$[-0.91014]$}
\end{tabular}


Conclusão: A única variável significante na relação de longo prazo são as exportações. O componente financeiro só seria significante a 20\% (10\% unicaldal) e contribuiria negativamente para o produto. Os termos de intercâmbio são não significantes.

\title{
H.3 Testes sobre as variáveis de ajuste e Casualidade de Gran- ger
}

\section{Coeficiente Ajustamento da Renda}

\author{
Vector Error Correction Estimates \\ Sample(adjusted): 19322004 \\ Included observations: 73 after adjusting endpoints \\ Cointegration Restrictions: \\ $A(1,1)=0$ \\ Convergence achieved after 12 iterations. \\ Not all cointegrating vectors are identified \\ $L R$ test for binding restrictions (rank = 1): \\ Chi-square(1) $\quad 7.256494$ \\ Probability $\quad 0.007065$
}

\section{Coeficiente de Ajustamento das Exportações}

\author{
Vector Error Correction Estimates \\ Sample(adjusted): 19322004 \\ Standard errors in () \& -statistics in [] \\ Cointegration Restrictions: \\ $A(2,1)=0$ \\ Convergence achieved after 14 iterations. \\ Not all cointegrating vectors are identified \\ LR test for binding restrictions (rank = 1): \\ Chi-square(1) $\quad 0.025573$ \\ Probability $\quad 0.872949$
}

Included observations: 73 after adjusting endpoints

\section{Coeficiente de Ajustamento do Financeiro}

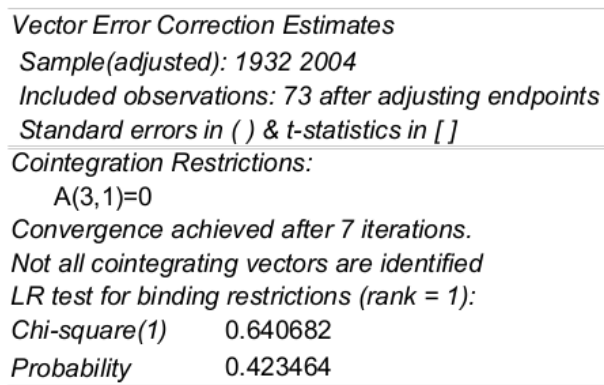




\section{Coeficiente de Ajustamento do Câmbio}

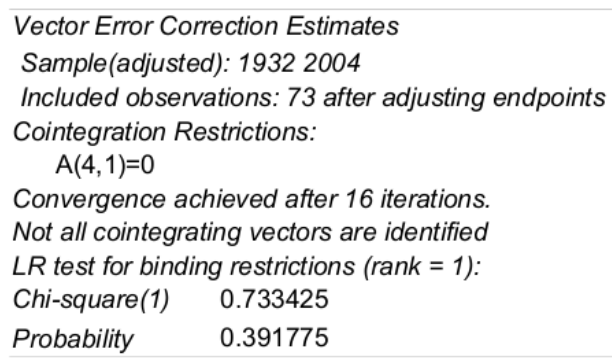

O único coeficiente de ajustamento diferente de 0 é o da renda e tem o sinal esperado. Ou seja, é a única variável que se moveria no curto prazo para voltar ao equilíbrio de longo prazo.

Exportações, câmbio e o componente financeiro podem ser considerados fracamente exógenos. Já a renda é endógena, ou se ajusta para corrigir os desequilíbrios do Balanço de Pagamentos.

As exportações são fracamente exógenas e podem ser consideradas fortemente exógenas a 5\%. Isso implica que as exportações não são granger causadas seja pela renda, seja pelo componente financeiro, seja pelo câmbio a este nível de significância.

O componente financeiro também é fortemente exógeno, não sendo causado por nenhuma das variáveis. O resultado mais surpreendente é a taxa de câmbio, também fortemente exógena. Apenas a pouco mais de $20 \%$ de significância poderíamos aceitar que financeiro Granger-causa câmbio. 
VEC Pairwise Granger Causality/Block Exogeneity Wald Tests Sample: 19302004

Included observations: 73

Dependent variable: $D(L Y R)$

$\begin{array}{cccl}\text { Exclude } & \text { Chi-sq } & d f & \text { Prob. } \\ \text { D(LX) } & 0.559633 & 1 & 0.4544 \\ \text { D(LFINM2) } & 3.637141 & 1 & 0.0565 \\ \text { D(LER) } & 0.545757 & 1 & 0.4601 \\ \text { All } & 4.390707 & 3 & 0.2222\end{array}$

Dependent variable: $\mathrm{D}(\mathrm{LX})$

\begin{tabular}{cccc} 
Exclude & Chi-sq & df & Prob. \\
\hline D(LYR) & 3.789834 & 1 & 0.0516 \\
D(LFINM2) & 2.473971 & 1 & 0.1157 \\
D(LER) & 0.546311 & 1 & 0.4598 \\
\hline All & 6.160456 & 3 & 0.1041
\end{tabular}

Dependent variable: D(LFINM2)

\begin{tabular}{cccc}
\hline Exclude & Chi-sq & df & Prob. \\
\hline D(LYR) & 0.437183 & 1 & 0.5085 \\
D(LX) & 2.041392 & 1 & 0.1531 \\
D(LER) & 0.144477 & 1 & 0.7039 \\
All & 3.450332 & 3 & 0.3273
\end{tabular}

Dependent variable: D(LER)

\begin{tabular}{cccc}
\hline Exclude & Chi-sq & df & Prob. \\
\hline \hline D(LYR) & 0.358413 & 1 & 0.5494 \\
D(LX) & 0.275991 & 1 & 0.5993 \\
D(LFINM2) & 1.597279 & 1 & 0.2063 \\
\hline All & 2.735053 & 3 & 0.4343 \\
\hline \hline
\end{tabular}

\section{H.4 Testes dos resíduos}

\section{Variável Renda}

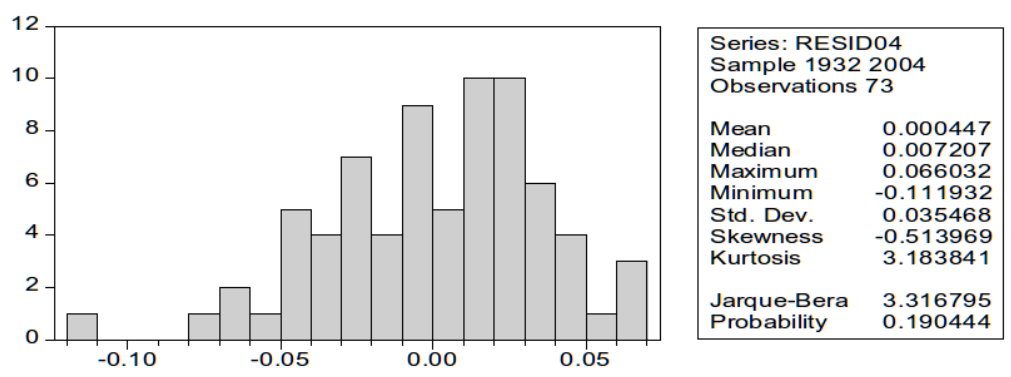

Conclusão: Aceitamos a hipótese de normalidade. 


\section{Variável Exportações}
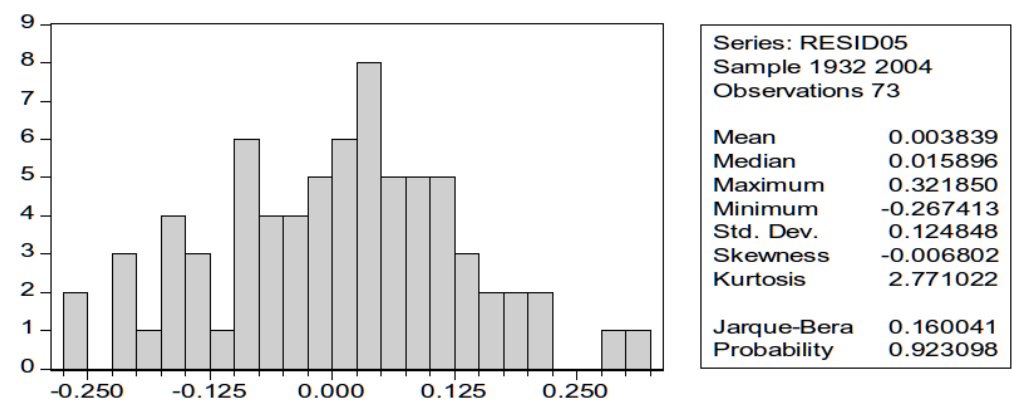

Conclusão: Aceitamos a hipótese de normalidade.

\section{Variável Componente Financeiro}
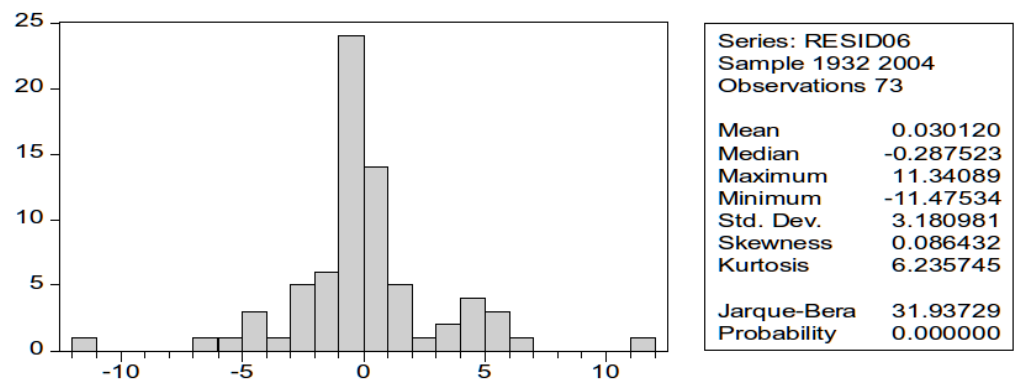

Conclusão: Rejeitamos a hipótese de normalidade. Como o problema era tanto de curtose como de assimetria, a inclusão de dummys não melhorou o resultado. Assim, retiramos as dummies e esperamos que a amostra relativamente grande permita a estimação por quase máxima verossimilhança.

\section{Variável Câmbio Real}
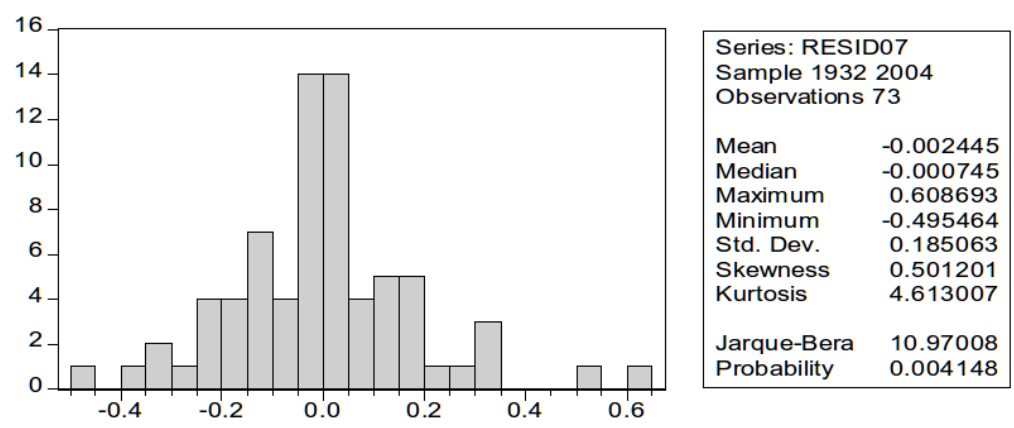

Conclusão: Rejeitamos a hipótese de normalidade. Como aqui também, o problema era tanto de curtose como de assimetria, a inclusão de dummies não melhorou o resultado. Assim, retiramos as dummies e esperamos que a amostra relativamente grande permita a estimação por quase máxima verossimilhança. 